UNIVERSIDADE DE SÃO PAULO

FACULDADE DE FILOSOFIA, LETRAS E CIÊNCIAS HUMANAS

DEPARTAMENTO DE GEOGRAFIA

ANA CRISTINA MACHADO RODRIGUEZ

A Cartografia temática digital do estado de São Paulo (SP).

São Paulo

2010 
UNIVERSIDADE DE SÃO PAULO

FACULDADE DE FILOSOFIA, LETRAS E CIÊNCIAS HUMANAS

DEPARTAMENTO DE GEOGRAFIA

\section{A Cartografia temática digital do Estado de São Paulo (SP).}

ANA CRISTINA MACHADO RODRÍGUEZ

Tese apresentada ao Departamento de Geografia da Faculdade de Filosofia, Letras e Ciências Humanas da Universidade de São Paulo, para a obtenção do título de Doutora em Ciências.

Área de Concentração: Geografia Humana

Orientador: Prof. Dr. Marcello Martinelli

São Paulo

2010 
AUTORIZO A REPRODUÇÃO E DIVULGAÇÃO TOTAL OU PARCIAL DESTE TRABALHO, POR QUALQUER MEIO CONVENCIONAL OU ELETRÔNICO, PARA FINS DE ESTUDO E PESQUISA, DESDE QUE CITADA A FONTE.

Ficha catalográfica

Elaborada por Maria Imaculada da Conceição - CRB8-6409

Rodriguez, Ana Cristina Machado

A cartografia temática digital do estado de São Paulo (SP) / Ana Cristina Machado Rodriguez ; orientador Marcello Martinelli. -- São Paulo, 2010.

236 f. ; il.

Tese (Doutorado - Programa de Pós-Graduação em Geografia Humana) - Faculdade de Filosofia, Letras e Ciências Humanas da Universidade de São Paulo.

1. Uso do solo - São Paulo. 2. Cobertura do solo - São Paulo. 3. Mapas temáticos. 4. Cartografia digital. 5. Geoprocessamento. 6. MODIS. I. Título. II. Martinelli, Marcello. 


\section{FOLHA DE APROVAÇÃO}

ANA CRISTINA MACHADO RODRIGUEZ

A Cartografia temática digital do

Estado de São Paulo (SP).

Tese apresentada ao Departamento de Geografia da Faculdade de Filosofia, Letras e Ciências Humanas (FFLCH) da Universidade de São Paulo (USP), para a obtenção do título de Doutora em Ciências.

Área de Concentração: Geografia Humana

Aprovado em:

\section{Banca Examinadora}

Prof. Dr.

Instituição: Assinatura:

Prof. Dr.

Instituição: Assinatura:

Prof. Dr.

Instituição: Assinatura:

Prof. Dr.

Instituição: Assinatura:

Prof. Dr.

Instituição: Assinatura: 
Primeiramente a Deus pela minha existência, Á meu amado e querido Pai que se foi, mas me deixou incriveis conhecimentos de vida e amor (in memorian); A minha mãe que se fortalece dia-a-dia na companfia dos netos para amenizar a dor pela perda de seu companheiro;

A meu esposo por sua simples presença e apoio; Ao meu tão esperado filho GAEL que é minha principal fonte de vida, renovação, inspiração e criação. 
"A mente que se abre para uma nova idéia jamais volta ao seu tamanho natural" (Albert Einstein). 


\section{RESUMO}

RODRíGUEZ, A. C. M. A Cartografia temática digital do estado de São Paulo (SP). 2010. 236f. Tese (Doutorado) - Faculdade de Filosofia, Letras e Ciências Humanas, Universidade de São Paulo, São Paulo, 2010.

O presente trabalho de pesquisa tem como principal objetivo produzir o Mapa de Uso e Cobertura da Terra na escala de 1: 2.500 .000 para o estado de São Paulo, além de disponibilizar um conjunto de diversos mapas temáticos do Estado de São Paulo em formato digital e no contexto de um Sistema de Informação Geográfica. O referido mapa de Uso pretende caracterizar as diversas formas de uso e cobertura da terra observadas no referido território. Nesta abordagem metodológica em escala regional destaca-se o emprego de imagens de satélite de alta resolução temporal e técnicas avançadas de processamento digital e o Geoprocessamento, como instrumental de integração e análise dos conhecimentos das ciências Geografia, Agronomia e Cartografia, as quais possibilitaram um levantamento do espaço geográfico relacionando-o com as interferências e ações da sociedade na natureza. A área de estudo está localizada na região sudeste do Brasil e tem uma extensão de 248.209,426 km² distribuídos em 645 municípios. Neste trabalho foram utilizadas as técnicas de segmentação e modelo linear de mistura espectral aplicados nas imagens do sensor MODIS, as quais facilitaram a delimitação das principais modalidades de uso e cobertura da terra. A classificação de uso e cobertura foi elaborada com base em mapeamentos clássicos de KELLER (1969), ANDERSON (1971) e et al.,(1979), JENSEN (1983) e TROPPMAIR (1983). Os produtos índices de vegetação (EVI e NDVI) contribuíram na aferição das classes temáticas de vegetação, os dados do Projeto CANASAT (INPE) nas classes de agricultura e as imagens do satélite CBERS e o do Google EARTH nas demais. Foram confeccionados diversos mapas temáticos em formato digital para a caracterização da área de estudo como, Geologia, Divisão geomorfológica, Bacias hidrográficas, Clima, Cobertura Vegetal Primitiva, alguns advindos do Projeto Atlas do estado de São Paulo: uma reflexão metodológica (MARTINELLI, 2009). Os mapas de relevo e declividade foram obtidos através dos dados do Shuttle Radar Topographic Mission (SRTM). Os resultados acerca das formas de uso e cobertura da terra destacam a supremacia agrícola pelo cultivo de cana-de-açúcar a qual vem pressionando e substituindo outros cultivos, o reflorestamento e as áreas de preservação e conservação ambiental. Esta ocupação desenfreada já vinha sendo apontada em pesquisas realizadas por RUDORFF et al., (2004) desde 2003 alavancada pela demanda na produção do etanol como biocombustível. Desta forma, esperamos que os resultados apresentados neste trabalho contribuam a futuros estudos quanto à ameaça aos fragmentos de cerrado e remanescentes de Mata Atlântica ainda presentes no estado de São Paulo, além das possibilidades de disponibilizar em Rodríguez, A. C. M. 
formato WebGIS a cartografia temática elaborada para seu amplo uso e divulgação à comunidade nacional e internacional.

Palavras-chave: Uso e cobertura da Terra, Estado de São Paulo, MODIS, Cartografia, Geoprocessamento 


\section{ABSTRACT}

\section{RODRíGUEZ, A. C. M. The digital thematic cartography of the state of São Paulo (SP).}

2010. 236 f. Thesis (Doctoral) - Faculty of Philosophy and Humanities, University of São Paulo, São Paulo, 2010.

The main objective of this research work is to produce the Land Use and Cover Map of São Paulo State in scale 1:2.500.000, and also to provide a diverse set of thematic maps of São Paulo State in digital format and in the context of a Geographic Information System. The Land Use and Cover Map have the purpose to characterize the diverse land use and cover forms observed in that territory. This mapping regional scale methodological approach is based on the use of high temporal resolution satellite images and advanced digital image processing and GIS technologies as an analysis and integration tool of Geography, Cartography and Agronomy science knowledge, creating a possibility of survey of geographical space linking it with the interference and actions of society in nature. The study area is located in southeastern Brazil and has an area of $248.209 .426 \mathrm{~km}^{2}$ distributed in 645 municipalities. In this work the segmentation technique and linear mixture model were applied in the sensor MODIS images, to facilitate the delimitation of the main land use and land cover classes. The land use and land cover classification was developed based on KELLER (1969), ANDERSON (1971), et al. (1979), JENSEN (1983) and TROPPMAIR (1983) classical mappings. Vegetation indices (NDVI and EVI) products contributed in gauging the thematic classes of vegetation, the CANASAT project data (INPE) in the agricultural classes and CBERS satellite images and Google Earth as well in the others. Several thematic maps in digital format were made for the study area characterization, Geology, Geomorphology, Watersheds, Climate, Primitive Vegetation Cover, some comings from the Atlas of São Paulo State project: a methodological reflection (MARTINELLI, 2009). The topography and slope maps were obtained from Shuttle Radar Topographic Mission (SRTM) data. The land use and land cover mapping results highlights the agricultural supremacy of cane sugar crop, which has been pressing and substituting other crops, the reforestation and environmental conservation areas as well. This wild occupation had already been appointed since 2003 by RUDORFF et al. (2004) pushed by ethanol production demand as a bio-fuel. Therefore, we hope that the results presented in this work contributes to future studies regarding the threat to fragments of Cerrado and Atlantic Forest remnants that are still present in São Paulo State, besides the possibilities to put on line in a WebGIS format the elaborated thematic maps for its widespread use and dissemination by the national and international community.

Keywords: Use and coverage, State of São Paulo, MODIS, Cartography, Geoprocessing 


\section{RESUMEN}

\section{RODRíGUEZ, A. C. M. La cartografía digital temática del estado de São Paulo (SP).} 2010. 236 f. Tesis (Doctorado) - Facultad de Filosofía y Humanidades de la Universidad de São Paulo, São Paulo, 2010.

La presente investigación tiene como objetivo principal desarrollar el Mapa de Uso y Cobertura del Suelo para el estado de São Paulo, en una escala de 1: 2.500.000, además de proporcionar un conjunto diverso de mapas temáticos de São Paulo, en formato digital y en el contexto de un Sistema de Información Geográfica. El mapa de Uso pretende caracterizar las distintas formas de uso y ocupación del suelo que se observan en este territorio. En este enfoque metodológico de mapeo a escala regional se destacan el uso de imágenes satelitales de alta resolución temporal y técnicas avanzadas de procesamiento digital y geoprocesamiento, como instrumento de integración y análisis de los conocimientos científicos de las ciencias de Geografía, Cartografía y Agronomía, lo que permitió un levantamiento del espacio geográfico en relación con las interferencias y las acciones de la sociedad en la naturaleza. El área de estudio está localizada en la región sureste de Brasil, con una extensión de 248.209,426 km² distribuidos en 645 municipios. Para este trabajo fueron utilizadas las técnicas de segmentación y el modelo lineal de mezcla espectral, aplicados en las imágenes del sensor MODIS, lo que facilitó la delimitación de los principales modos de uso y cobertura del suelo. La clasificación de uso y cobertura fue elaborada sobre la base de los mapeos clásicos de KELLER (1969), ANDERSON (1971) y et al. (1979), JENSEN (1983) y TROPPMAIR (1983). Los índices de vegetación (EVI y NDVI) contribuyeron para la verificación de las clases temáticas de vegetación, los datos del proyecto CANASAT (INPE) en los tipos de agricultura y las imágenes del satélite CBERS y de Google EARTH en las demás clases. Fueron confeccionados diversos mapas temáticos en formato digital para la caracterización del área de estudio tales como, Geología, División geomorfológica, Cuencas hidrográficas, Clima y Área de vegetación primitiva, algunos derivados del Proyecto Atlas del estado de São Paulo: un análisis metodológico (MARTINELLI, 2009). Los mapas de topografía y pendiente se obtuvieron a través de los datos de la Shuttle Radar Topográfico Mission (SRTM). Los resultados relacionados con las formas de uso y cobertura del suelo evidencian la supremacía agrícola del cultivo de la caña de azúcar, la cual ha venido presionando y sustituyendo a otros cultivos, la reforestación y las áreas de preservación ambiental. Esta ocupación desenfrenada ya había sido señalada desde 2003 en investigaciones realizadas por RUDORFF et al., (2004) impulsada por la demanda de la producción de etanol como biocombustible. Por lo tanto, esperamos que los resultados presentados en este trabajo contribuyan a futuros estudios relacionados con la amenaza a los fragmentos de "cerrado" (savana) y los remanentes del bosque atlántico que 
aún existen en el estado de São Paulo, además de la posibilidad de tornar disponible en formato WebGIS la cartografía temática elaborada para su uso y divulgación de forma amplia en las comunidades científicas nacional e internacional.

Palabras clave: Uso y cobertura del suelo, Estado de São Paulo, MODIS, Cartografía, Geoprocesamiento 


\section{AGRADECIMENTOS}

Ao Orientador, Professor e Doutor Marcello Martinelli pelo carinho, resignação, oportunidade, motivação e incentivo no desenvolvimento desta tese e durante todo meu período acadêmico na FFLCH/USP.

Ao Prof. Dr. Reinaldo Paul Pérez Machado do Departamento de Geografia Humana da FFLCH-USP pela amizade e ensinamentos durante o desenvolvimento de meus trabalhos.

Ao Prof. Dr. Eymar Silva Sampaio Lopes da Divisão de Processamento de Imagens do Instituto Nacional de Pesquisas Espaciais - INPE por sua criteriosa revisão, comentários e sugestões no relatório de qualificação.

Ao Prof. Dr. Bernardo Friedrich Theodor Rudorff da Divisão de Sensoriamento Remoto do Instituto Nacional de Pesquisas Espaciais - INPE pela concessão dos dados de cana-de-açúcar do Projeto CANASAT.

Ao CNPq pela concessão de Bolsa de doutorado e pelo apoio financeiro para a realização deste trabalho de pesquisa.

A Universidade de São Paulo em especial a Faculdade de Filosofia, Letras e Ciências Humanas pela oportunidade de realização deste curso de doutorado.

Ao Grupo de Oração Imaculado Coração de Maria do Instituto de Geociências em especial, as amigas Sueli, Cleide, Conceição, Ivete, Lourdes, Luceir e ao amigo Mário pelo carinho e orações constantes de paz e tranqüilidade durante essa fase de minha vida.

Em especial a companheira, amiga, aluna e colega de Pós-Graduação Teresinha Marques que infelizmente não está mais entre nós, mas contribuiu com seu sorriso, abraço e palavras de superação nos momentos de dúvidas e incertezas.

Aos amigos Erickson, Elisângela, Zelinda, José Armando e Tamara simplesmente pela amizade e carinho compartilhados durante a realização deste trabalho de pesquisa.

À grande amiga Vera Gabriel Fontes da Secretaria de Pós-Graduação do INPE que sempre estava disposta em incentivar e ajudar no desenvolvimento desta tese.

Á amiga e ex-funcionária Maria Imaculada da Conceição da Biblioteca da FFLCH pela revisão das normas quanto às referências bibliográficas.

Às funcionárias da Secretaria da Pós-Graduação em especial a Ana Pereira que sempre esteve a postos para ajudar, ouvir e orientar nas burocracias da FFLCH. 
Aos amigos Oswaldo, Tião e Luciana da Secretaria de Graduação pelas brincadeiras que tornaram os dias mais alegres e divertidos durante o desenvolvimento desta.

Aos meus sobrinhos Alderinho, Gabriel e Gabrielly pelo carinho e doação de seu amor incondicional mesmo quando estava sem tempo para eles.

Ao meu braço direito e esquerdo Rute Lima que me proporcionou a tranquilidade e segurança quanto aos cuidados de meu filho Gael Yi durante o fechamento da Tese.

A Layka e ao Bicho pelo companheirismo e graciosidade durante as madrugadas de estudo no desenvolvimento desta pesquisa.

Finalmente, desculpo-me por ter esquecido alguém e agradeço aos colegas e amigos que colaboraram com esta pesquisa pela troca de idéias ou simplesmente por sugestões construtivas. 


\section{LISTA DE ILUSTRAÇÕES}

FIGURA 1 - Mapa de Bedolina no norte da Itália. ............................................ 52

FIGURA 2 - $\quad$ Mapa mais antigo conhecido descoberto em Ga-Sur. ....................... 52

FIGURA 3 - $\quad$ Mapa esquemático das Ilhas de Marshall. ........................................ 53

FIGURA 4 - $\quad$ O "Teatrum Orbis Terrarum". ........................................................... 56

FIGURA 5 - Esquema da comunicação monossêmica. ....................................... 62

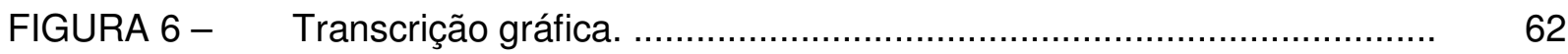

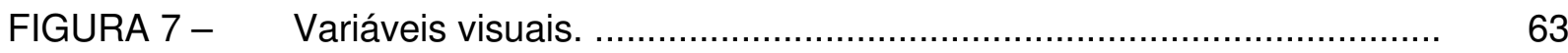

FIGURA 8 - $\quad$ Aspectos evidenciados na Cartografia temática. ............................... 65

FIGURA 9 - Disposição das faixas do espectro eletromagnético .......................... 66

FIGURA 10 - Círculo cromático (Cores frias e quentes). ..................................... 67

FIGURA 11 - Vila Petit Bicètre perto de Paris ................................................... 83

FIGURA 12 - Esquema de um onda eletromagnética ....................................... 87

FIGURA 13 - Obtenção de imagens por SR …............................................... 88

FIGURA 14 - Captura de dados no campo pelo espectroradiômetro ....................... 89

FIGURA 15 - Resposta espectral da cana-de-açúcar ......................................... 96

FIGURA 16 - Perfil espectral das culturas de soja, milho e algodão ....................... 97

FIGURA 17 - Curvas de reflectância dos Rios Tietê, Piracicaba e do Reservatório 98 de Barra Bonita - SP

FIGURA 18 - Tiles MODIS h13v10 e h13v11 que cobrem o estado de São Paulo. . 103

FIGURA 19 - Mosaico de imagens MODIS (MOD13) do estado de São Paulo. ...... 103

FIGURA 20 - Esquema de aquisição dos dados SRTM ................................... 108

FIGURA 21 - Mosaico de imagens NDVI e EVI (MODIS) do estado de São Paulo.. 116

FIGURA 22 - Captura de pixels puros diretamente da Imagem Landsat ................. 117

FIGURA 23 - Captura do pixel puro (vegetação, solo e água) …............................ 118

FIGURA $24-\quad$ Imagem original + segmentação + imagem segmentada ................... 120

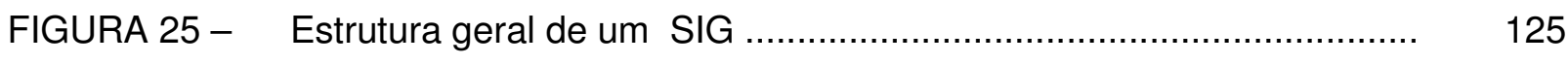

FIGURA 26 - Localização do estado de São Paulo. ……...................................... 135 
FIGURA 27 - ESTADO DE SÃO PAULO - DIVISÃO MUNICIPAL

FIGURA 28 - ESTADO DE SÃO PAULO - HIDROGRAFIA .

FIGURA 29

ESTADO DE SÃO PAULO - GEOLOGIA .

FIGURA 30

ESTADO DE SÃO PAULO - DIVISÃO GEOMORFOLÓGICA

142

FIGURA 31

ESTADO DE SÃO PAULO - UNIDADES DE RELEVO

FIGURA 32 -

ESTADO DE SÃO PAULO - BACIAS HIDROGRÁFICAS

FIGURA 33

ESTADO DE SÃO PAULO - CLIMA

FIGURA 34

ESTADO DE SÃO PAULO - SOLOS

151

FIGURA 35

ESTADO DE SÃO PAULO - COBERTURA VEGETAL PRIMITIVA ...

FIGURA 36 -

ESTADO DE SÃO PAULO - VEGETAÇÃO NATIVA

154

FIGURA 37

Mapa da sequência do desmatamento no estado de São Paulo. ......

FIGURA 38 - ESTADO DE SÃO PAULO - UNIDADES DE CONSERVAÇÃO

FIGURA 39

Parque estadual da Serra do Mar (PESM)

FIGURA $40-$

ESTADO DE SÃO PAULO - APTIDÃO CLIMÁTICA PARA A CAFEICULTURA

FIGURA 41 - Planta da cidade de São Paulo.

FIGURA 42 - Mapa do levantamento do uso das terras em 1962 do estado de São Paulo

FIGURA 43 - Mapa de uso e cobertura da terra do estado de São Paulo

FIGURA 44 - Crescimento populacional do estado de São Paulo (1991 - 2000)....

FIGURA 45 - ESTADO DE SÃO PAULO - REDE VIÁRIA .

FIGURA 46 -

ESTADO DE SÃO PAULO - CARTAS TOPOGRÁFICAS 1:500.000

FIGURA 47 - Fluxograma de atividades ....

FIGURA 48 - ESTADO DE SÃO PAULO - RELEVO

FIGURA 49 - Classes de altitude do estado de São Paulo

FIGURA 50

ESTADO DE SÃO PAULO - DECLIVIDADE

FIGURA 51 - Classes de declividade do estado de São Paulo .....

FIGURA 52 - ESTADO DE SÃO PAULO - EVI (Enhanced Vegetation Index) 
FIGURA 53 - ESTADO DE SÃO PAULO - NDVI (Normalized Difference Vegetation Index)

FIGURA 54 - Reflorestamento nas Imagens CBERS e do Google EARTH do estado de São Paulo

FIGURA 55 - Remanescentes nas Imagens MODIS e do Google EARTH do estado de São Paulo

FIGURA 56 - ESTADO DE SÃO PAULO - USO E COBERTURA DA TERRA 2009

FIGURA 57 - Classes de uso e cobertura da terra (2009) do estado de São Paulo

FIGURA 58 - Comparação das áreas totais de cerrado no estado de São Paulo..

FIGURA 59 - Cana-de-açúcar nas imagens MODIS e do Google EARTH do estado de São Paulo

FIGURA 60 - Tipos de uso e cobertura da terra em imagens TM/Landsat no estado de São Paulo 


\section{LISTAS DE TABELAS}

TABELA 1 - Modalidades de usos da terra com sua respectiva cor associada 74

TABELA 2 -

Descrição das formas usos da terra 74

TABELA 3 Classificação do IBGE para classes de uso da terra 75

TABELA 4 -

Sistema de classificação de uso e cobertura da terra por SR 79

TABELA 5 Classificação do USGS para categorias de uso da terra 80

TABELA 6 Intervalos de revisita de alguns satélites de SR 101

TABELA 7 No. de bandas e resolução espectral do sensor MODIS 101

TABELA 8 Relação da escala cartográfica versus resolução espacial 102

TABELA 9 Alguns produtos da área continental do MODIS

TABELA 10 - Estudos por áreas de atuação da tecnologia espacial 110

TABELA 11 - Os Índices EVI e NDVI

TABELA 12 - Tipos de dados identificados como entidades

TABELA 13 - Relação das barragens do estado de São Paulo.

TABELA 14 - Tipos de usos da terra com sua caracterização no estado de São Paulo . 168

TABELA 15 - Relação da população dos municípios da R. M. de São Paulo

TABELA 16 - Relação da população dos municípios da R. M. da Baixada Santista SP.

TABELA 17 - Relação da população dos municípios da R. M. de Campinas - SP

TABELA 18 -

Recursos financeiros estaduais e federais aplicados em 2005 no estado de São Paulo

TABELA 19 - Relação dos terminais hidroviários do estado de São Paulo.

TABELA 20 - Relação de cartas topográficas do estado de São Paulo.

TABELA 21 - Relação de mapas temáticos do estado de São Paulo 


\section{LISTA DE ABREVIATURAS E SIGLAS}

ACQUA

AMSU

AMSR-E

APA

ASTER

ARVI

AVHRR

$\mathrm{BD}$

BDG

BRDF

CBERS

CCD

CEB

CEPAGRI

CEPEA

CERES

CENPES

CGIS

CND

CNTE

$\mathrm{CNPq}$

CONAB

COSIPA

CSIRO

CTC

CTI

CZSC

DAEE

DCDSTF

DSG

DPI

EMBRAPA

EMPLASA

ENVI
Segunda plataforma do EOS

Advanced Microwave Sounding Unit

Advanced Microwave Scanning Radiometer for EOS

Área de Proteção Ambiental

Advanced Spaceborne Thermal Emission and Reflection Radiometer

Atmosphere Resistant Vegetation Index

Advanced Very High Resolution Radiometer

Banco de Dados

Banco de Dados Geográfico

Bidirectional Reflectance Distribution Fuction

China Brasil Earth Resources Satellite

Charge Coupled Devices

Câmara de Educação Básica

Centro de Pesquisas Meteorológicas e Climáticas Aplicadas à Agricultura

Centro de Estudos Avançados em Economia Aplicada

Clouds and the Earth's Radiant Energy System

Centro de Pesquisas Leopoldo Américo Miguez de Mello

Canadian Geographic Information System

Conselho Nacional de Desestatização

Confederação Nacional dos Trabalhadores em Educação

Conselho Nacional de Desenvolvimento Científico e Tecnológico

Companhia Nacional de Abastecimento. Ministério da Agricultura

Companhia Siderúrgica Paulista

Commonwealth Scientific and Industrial Research Organization

Centro de Tecnologia Canavieira

Centro Tecnológico para Informática

Coastal Zone Collor Scanner

Departamento de Águas e Energia Elétrica

Digital Cartographic Data Standard Task Force

Diretória de Serviço Geográfico do Exercito

Divisão de Processamento de Imagens (INPE)

Empresa Brasileira de Pesquisa Agropecuária

Empresa Paulista de Planejamento Metropolitano S.A.

Environment for Visualizing Images 
EOS

EOS-AM

EOS-PM

EOSDIS

ETM

EVI

FAO

FAPAR

FAPESP

FEPASA

GARI

GRIB

HBS

HDF

IAC

IAF

IBGE

IDH

IDL

IF

IFOV

IG

IGC

IGG

INEP

INPE

IPT

ITA

ITESP

IV

IVM

IVP

IVT

LAI

LEGAL

LNLS

MEC
Earth Observing System

Observações no período da manhã

Observações no período da tarde

Earth Observing System Data and Information System

Enhanced Thematica Mapper Plus

Enhanced Vegetation Index

Organização das Nações Unidas para Agricultura e Alimentação

Fraction of Photosynthetically Active Radiation absorbed by vegetation

Fundação de Amparo à Pesquisa do Estado de São Paulo.

Ferrovia Paulista S/A

Green Atmospherically Resistant Vegetation Index

Gridded Binary

Humidity Sounder for Brasil

Hierarchy Data Format

Instituto Agronômico de Campinas

Índice de Área Foliar

Instituto Brasileiro de Geografia e Estatística

Índice de Desenvolvimento Humano

Interactive Data Language

Instituto Florestal

Instantaneous Field Of View

Instituto Geográfico

Instituto de Geociências

Instituto Geográfico e Geológico

Instituto Nacional de Estudos e Pesquisas

Instituto Nacional de Pesquisas Espaciais

Instituto de Pesquisas Tecnológicas

Instituto Tecnológico da Aeronáutica

Instituto de Terras

InfraVermelho

InfraVermelho Médio

InfraVermelho Próximo

InfraVermelho Termal

Leaf Area Index

Linguagem Espacial para Geoprocessamento Algébrico

Laboratório Nacional de Luz Síncroton

Ministério da Educação 
MECB

MDE

MCT

MLME

MNT

MOD13

MODLAND

MODIS

MOPITT

MSS

NASA

ND

NDVI

NOAA

PESM

PDI

PI

PIB

PGE

RBV

REM

RGB

RM

RPNB

RSI

SADT

SAVI

SEADE

SEMA

SGDB

SIG

SITIM

SMA

SNUC

SPRING

SR

SRTM
Programa Missão Espacial Completa Brasileira

Modelo Digital Elevação

Ministério de Ciência e Tecnologia

Modelo Linear de Mistura Espectral

Modelo Numérico do Terreno

Produto MODIS índice de vegetação

Produtos MODIS para o estudo dos ecossistemas terrestres

Moderate-resolution Imaging Spectroradiometer

Measurement of Pollution in the Troposphere

Multispectral Scanner Subsystem

National Aeronautics and Space Administration

Número Digital

Normalized Difference Vegetation Index

National Oceanic and Atmospheric Adminstration

Parque Estadual da Serra do Mar

Processamento Digital de Imagens

Plano de Informação (SPRING)

Produto Interno Bruto

Procuradoria Geral do Estado

Return Beam Videocon

Radiação EletroMagnética

Red, Green, Blue (Vermelho, Verde, Azul)

Região Metropolitana

Regulamento dos Parques Nacionais Brasileiros

Research Systems, Inc.

Serviço de Apoio a Diagnose e Terapia

Soil-Adjusted Vegetation Index

Fundação Estadual de Análise de Dados

Secretaria do Meio Ambiente

Sistema Gerenciador de Bancos de Dados

Sistema Informação Geográfica

Sistema de Tratamento de Imagens

Secretaria do Meio Ambiente

Sistema Nacional de Unidades de Conservação da Natureza

Sistema de Processamento de Informações Georeferenciadas

Sensoriamento Remoto

Shuttle Radar Topography Mission 


$\begin{array}{ll}\text { TERRA } & \text { Primeira plataforma do EOS } \\ \text { TIFF } & \text { Tagged Image File Format } \\ \text { TM } & \text { Thematic Mapper } \\ \text { UC } & \text { Unidade de Conservação } \\ \text { UEH } & \text { Usinas Hidrelétricas } \\ \text { UFSCAR } & \text { Universidade Federal de São Carlos } \\ \text { UFRJ } & \text { Universidade Federal do Rio de Janeiro } \\ \text { UGI } & \text { Unidade Geográfica Internacional } \\ \text { UNESP } & \text { Universidade Estadual Paulista } \\ \text { UNICA } & \text { União da Agroindústria Canavieira de São Paulo } \\ \text { UNICAMP } & \text { Universidade de Campinas } \\ \text { USDA } & \text { United States Department of Agriculture } \\ \text { USA } & \text { United States of America } \\ \text { USGS } & \text { United States Geological Survey } \\ \text { USP } & \text { Universidade do São Paulo } \\ \text { UTM } & \text { Universal Transversa de Mercator } \\ \text { WFI } & \text { Wide Field Imager } \\ \text { WGS84 } & \text { World Geodetic System 1984 }\end{array}$




\section{S U M Á R I O}

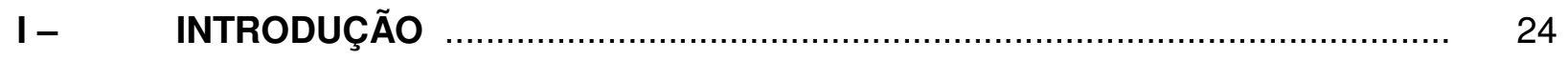

II - $\quad$ BASES TEÓRICAS E METODOLÓGICAS ……........................................... 28

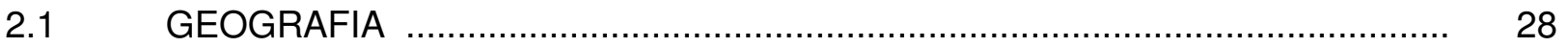

$2.2 \quad$ AGRONOMIA …………………………….................................. 42

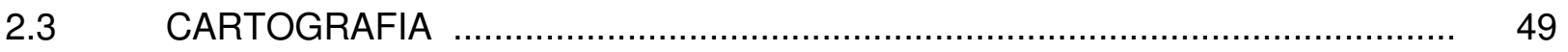

2.3.1 CARTOGRAFIA TEMÁTICA _....................................................................... 59

2.3.2 CARTOGRAFIA DO USO E COBERTURA DA TERRA ………....................... 71

2.3.2.1 Sensoriamento Remoto (SR) ………………………………………....... 82

2.3.2.2 Sistema de Informações Geográficas (SIG)................................................ 122

III - ÁREA DE ESTUDO ........................................................................... 134

3.1 LOCALIZAÇÃO E SITUAÇÃO GEOGRÁFICA ............................................... 134

3.2 CARACTERÍSTICAS AMBIENTAIS ........................................................... 138

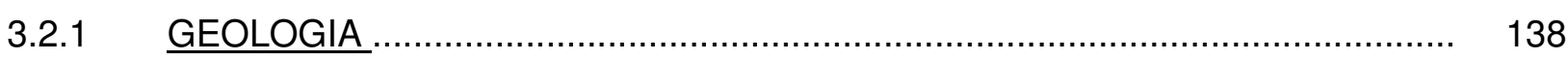

3.2.2 GEOMORFOLOGIA …………………………..................................... 141

3.2.3 HIDROGRAFIA ……………………………...................................... 145

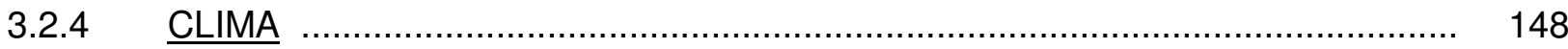

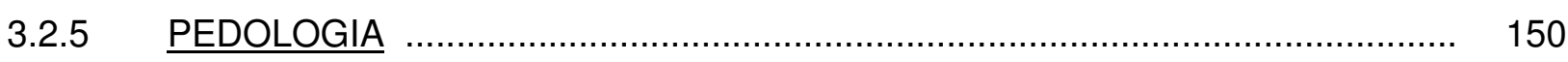

3.2.6 COBERTURA VEGETAL ........................................................................ 152

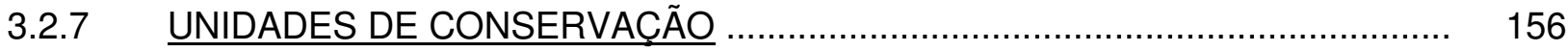

3.3 CARACTERÍSTICAS SÓCIOECONÔMICAS ……............................................ 161

3.3.1 PROCESSO DE OCUPACÃO ……………………................................... 161

3.3.2 USO E COBERTURA DA TERRA …………………................................. 167

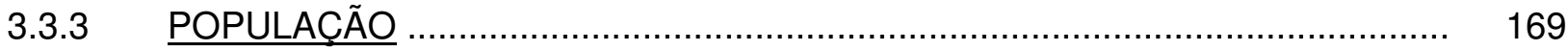

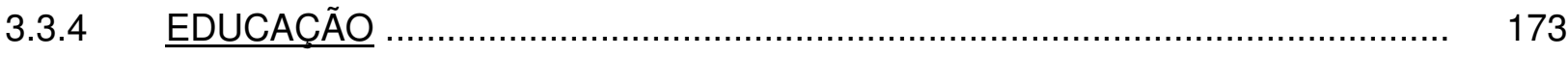

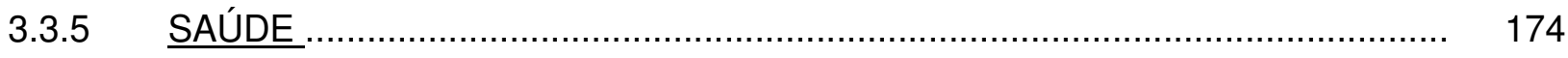

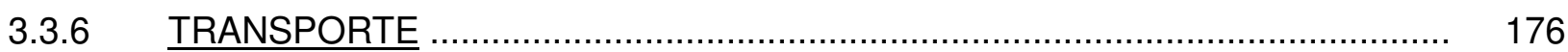


3.3.7 SEGURANCQA PÚBLICA

IV - $\quad$ CARTOGRAFIA DO USO E COBERTURA DA TERRA DO ESTADO DE SÃO PAULO

4.1 O METODO DE PESQUISA

4.2 RECURSOS: MATERIAIS, TÉCNICAS E EQUIPAMENTOS

4.3 PROCEDIMENTOS

4.3.1 DIGITALIZAC̣̃̃O E IMPORTAC̣̃̃O 185

4.3.2 PROCESSAMENTO DOS DADOS ORBITAIS E DE RADAR . 186

4.3.3 TRABALHO DE LABORATÓRIO 190

V - $\quad$ RESULTADOS E DISCUSSÕES 192

5.1 RELEVO E DECLIVIDADE DO ESTADO DE SÃO PAULO 192

5. 2 INDICES DE VEGETAÇÃO: EVI E NDVI DO ESTADO DE SÃO PAULO 198

5. 3 USO E COBERTURA DA TERRA DO ESTADO DE SÃO PAULO 202

VI - CONSIDERAÇÕES FINAIS E SUGESTÕES 209

VII - REFERÊNCIAS BIBLIOGRÁFICAS 212

VIII - APÊNDICE A 235 


\section{I - INTRODUÇÃO}

Com a conclusão do mestrado em 2006, no qual foram abordadas as temáticas sobre a legislação ambiental no estudo de áreas incompatíveis ao assentamento urbano no município de São Sebastião, a experiência formada no meu ingresso no campo da Geografia, por me interessar da representação do espaço geográfico através de mapas, consequente com a construção de banco de dados do software SPRING e o acesso ao Projeto do Atlas do estado de São Paulo constituíram discussões e indagações acerca das formas de uso e cobertura da terra no estado de São Paulo.

A problemática central surgiu a partir da divulgação pela impressa e outros veículos de comunicação sobre a atual expansão da cultura de cana-de-açúcar no estado de São Paulo devido à produção de bicombustível. Neste sentido, a investigação das modalidades de uso e cobertura da terra na escala de 1: 2.500 .000 nos mostra a complexa realidade caracterizada por fortes contrastes entre uma necessária preservação dos fragmentos de cerrado e remanescentes da Mata Atlântica em contrapartida por um demanda crescente de áreas agricultáveis visando os mercados nacional e internacional.

O Estado de São Paulo é um dos maiores estados do Brasil, o qual já tentou se tornar independente devido ao seu grande poder econômico centralizador. Em termos de produção agrícola seu maior destaque é o cultivo da cana-de-açúcar com $57,69 \%$ de produção do país. Conforme dados do projeto CANASAT (INPE), entre os anos de 2003 e 2007, a produção desta cultura saltou de, aproximadamente, 3.000 .000 ha (hectares) para 4.250.000 ha devido aos investimentos do etanol.

As implicações decorrentes deste crescimento agrícola tende a refletir enormemente no meio ambiente esgotando o solo e os recursos hídricos por conta do lançamento de defensivos entre outros insumos agrícolas. Segundo o Zonemamento Agroambiental elaborado pelas secretarias do Meio Ambiente e da Agricultura e Abastecimento apoiado pelo Governo, esta produção deverá permanecer acelerada, pois ainda existem terras adequadas para o cultivo da cana-de-açúcar (CONAB, 2009).

Desta forma, o crescimento contínuo da produtividade agrícola no estado de São Paulo atrelado aos avanços da biotecnologia nos reflete uma previsão que haverá uma ocupação crescente de solo agrícola com novos canaviais. No entanto, os recursos naturais necessários para abertura destas novas frentes agrícolas não são inesgotáveis. $\mathrm{E}$ o aumento da intervenção humana sobre o meio ambiente acarreta a extinção de várias espécies (ecossistemas) que antes eram tomados pela fauna e flora. 
É importante para o homem a transformação do meio ambiente para a produção do espaço urbano, o qual vem sendo totalmente modificado e alterado do que outrora era conhecido. Em SANTOS (1997) destacamos que o espaço habitado se tornou um meio geográfico completamente diversificado do que fora na aurora dos tempos históricos.

Cabe ressaltar que a transformação ou modificação do espaço tem como objetivo suprir e atender as necessidades da vida cotidiana como criação de estradas, escolas, cidades, cultivo de produtos agrícolas, projetos de habitação entre outros que podem garantir para a população melhores condições de infra-estrutura. Mas, isso não garante uma qualidade de desenvolvimento humano sem a preservação do meio ambiente.

A quebra do equilíbrio do meio ambiente pelas inúmeras ações e intervenções da sociedade humana provoca e cria sistemas muito frágeis e obviamente instáveis. Assim, o levantamento das formas de uso e cobertura da terra nos vislumbra as tendências no ano de 2009 de como estão organizados e dispostos os usos e coberturas da terra no estado.

Para tal nos apoiamos no teórico-metodológico das questões relacionadas à Geografia e a Cartografia. Tentando fazer uma conexão entre as questões Agronômicas, na qual tenho minha base formada e alicerçada. E assim, auxiliar na caracterização e no entendimento dos aspectos ambientais e humanos no estado de São Paulo, o qual poderá servir de ícone para outros estudos regionais.

As ciências como a Geografia, Agronomia e Cartografia associadas às técnicas da Cartografia Digital e do Geoprocessamento podem favorecer o levantamento destes usos e coberturas da terra visando representar em mapa o espaço geográfico para o reconhecimento dos padrões e a distribuição de organização do espaço.

A Geografia nos permitiu o entendimento e levantamento do espaço geográfico juntamente com as implicações da sociedade na natureza, assim como da relação que existe entre elas (GONÇALVES, 1989).

A Agronomia nos forneceu os conhecimentos das técnicas, práticas, manejos e ciclos de plantio das culturas, no caso da cana-de-açúcar. Além, do entendimento sobre as conseqüências e riscos ao meio ambiente sobre a expansão de monoculturas, as quais tendem a acelerar a degradação do solo, poluir os recursos hídricos entre outros.

A Cartografia nos possibilitou representar graficamente pelos mapas a situação real deste espaço geográfico, o estado de São Paulo. Pois, trata-se da construção seletiva e representativa que necessita de se conhecer as regras da sintaxe da linguagem da representação gráfica, a qual tem seu sustentáculo na Semiologia Gráfica (BERTIN, 1973). 
Desta forma, a união das áreas de Geografia, Agronomia e a Cartografia tem como objetivo primordial facilitar a compreensão da produção deste espaço geográfico possibilitando o estudo, a representação e a utilização correta dos mapas, cartas entre outros que possam desvendar a essência da informação como base da compreensão da própria realidade no referido estado. E juntamente com o Sensoriamento Remoto (SR) e Geoprocessamento tornam-se inigualáveis ferramentas para registrar, tratar e expor dados e informações, assim como resultados de pesquisas sobre problemas ambientais atrelados as relações sociedade e natureza.

É importante lembrar que os dados de sensores orbitais integrado aos sistemas de informação geográfica (SIG) são particularmente de grande utilidade no auxílio da discriminação de elementos de uso e cobertura da terra, em mapeamentos dos recursos naturais e também na espacialização de áreas de preservação.

Ressaltamos, ainda que os dados das imagens do sensor MODIS foram de fundamental importância no desenvolvimento desta pesquisa. Eles são um instrumental valioso na caracterização do comportamento de diferentes modalidades de uso e cobertura da terra. E a utilização dos produtos de índice de vegetação deste sensor, como EVI e NDVI são notadamente apropriados no levantamento da sazonalidade da vegetação.

Neste contexto, o presente trabalho tem como objetivo a produção do Mapa de uso e cobertura da terra do estado de São Paulo na escala de 1: 2.500.000. Utilizando-se das imagens do sensor MODIS e dos produtos de índice de vegetação EVI e NDVI, assim como das imagens-fração vegetação, solo e sombra. O referido mapa teve como base os mapeamentos históricos de KELLER (1969), ANDERSON (1971) e et al.,(1979), JENSEN (1983) e TROPPMAIR (1983). Assim, as principais formas de uso e cobertura da terra foram delimitadas e quantificadas nos dando um retrato atual da situação do estado.

Neste trabalho de pesquisa a área de estudo foi apresentada por diversos mapas temáticos com objetivo de caracterizar, quantificar e representar as variáveis ambientais, assim achou-se conveniente denominar-lo como "A Cartografia Temática Digital do Estado de São Paulo - $S P^{\prime}$.

Com base no exposto a estrutura desta pesquisa se apresenta em capítulos que explicitam o raciocínio desenvolvido em forma de tese. Assim, no Capítulo I introduzimos algumas considerações iniciais como a escolha da área de estudo e os parâmetros que nos levaram a elegê-la no objeto de estudo. São descritas também de forma geral as ciências e o instrumental utilizado, além dos objetivos e metas que pretendemos alcançar.

Por conseguinte, no Capítulo /l salientam-se as bases teóricas e metodológicas trazendo uma fundamentação das ciências empregadas e das técnicas envolvidas para a Rodríguez, A. C. M. 
realização da pesquisa. As mesmas são importantes para o entendimento de todos os procedimentos a serem desenvolvidos no percurso de todo o trabalho de pesquisa.

Seguindo, no Capítulo III apresentamos a localização e situação geográfica da referida área de estudo, além do processo de ocupação, as características ambientais e socioeconômicas.

No momento seguinte, no Capítulo IV destacam-se os materiais, técnicas e equipamentos eleitos para o desenvolvimento deste trabalho de pesquisa. Assim como, o método da pesquisa a ser utilizado juntamente com a descrição dos principais procedimentos envolvidos.

Continuando, no Capítulo $V$ descrevemos sucintamente os resultados alcançados a partir dos procedimentos desenvolvidos e também sua discussão. E no Capitulo VI apresentamos as considerações finais e sugestões.

Completam o trabalho o elenco das referências bibliográficas utilizadas e o apêndice contendo alguns programas em Linguagem Espacial para Geoprocessamento Algébrico (LEGAL), designados por Capítulo VII e Capítulo VIII. 


\section{II - BASES TEÓRICAS E METODOLÓGICAS}

No sentido de alcançarmos os objetivos dispostos neste trabalho de pesquisa precisaremos lançar mão das bases teórico-metodológicas das Ciências: Geografia, Agronomia e Cartografia. No entanto, utilizaremos também outras ciências correlatas que se façam necessárias, inclusive contribuições advindas da área técnica, ao longo deste capítulo.

Todas as ciências acima apontadas só serão comentadas desde que tenham e estabeleçam relações entre si visando uma interação de orientações que venham a solucionar os objetivos e alcançar as metas deste trabalho de pesquisa.

Falaremos primeiramente da Geografia, a qual envolve a relação existente do homem com o meio. Pois desta forma poderemos conhecer os processos que determinam a organização do espaço produzido e usado pela sociedade.

\subsection{GEOGRAFIA}

A palavra Geografia segundo os gregos significava "escrever sobre a terra", hoje essa definição evoluiu e esta ciência procura compreender as transformações que ocorrem no espaço geográfico de uma forma dinâmica havendo relação da sociedade compondo com a natureza.

A Geografia na sua evolução histórica tem o espaço produzido pela sociedade como principal objeto de estudo mediante a relação sociedade $\mathrm{x}$ natureza mediada pelo trabalho, viabilizando interesses socioeconômicos e ambientais.

Para MORAES (1983), o objeto de estudo da Geografia é definido de várias formas, de diferentes orientações metodológicas e concepções de mundo. Dentre esses conceitos podemos destacar como objeto de estudo desta ciência o estudo da superfície da terra, o estudo da paisagem, o estudo da individualidade dos lugares, o estudo da relação homem $x$ natureza e o estudo do espaço geográfico.

O objeto geográfico foi definido pelo cientista alemão Friedrich Ratzel como sendo o estudo da influência que as condições naturais exercem sobre a humanidade (MORAES, 2002). O homem é um agente ativo que sofre influências do meio construindo e modificando o espaço geográfico. Esse espaço é dinâmico e os elementos (naturais e sociais) que o compõem interagem de forma complexa nesse movimento determinando o próprio ambiente.

Segundo CORRÊA (2003), o espaço geográfico ou simplesmente espaço tem um significado muito amplo e vago, o qual está associado a uma porção específica da Terra 
identificada pela natureza ou pelas marcas impressas do homem ou ainda pela referência de localização geográfica.

No entanto, para SANTOS (1978), o espaço geográfico é definido como a natureza modificada pelo homem com seu trabalho. Onde, a concepção de natureza é vista num espaço sem a presença central do homem cedendo lugar à idéia de uma construção permanente da natureza artificial e/ou social, sinônimo de espaço geográfico.

Para SILVA (2001), que tomou como base os estudos realizados por Lefebvre, o espaço geográfico é definido como produto, processo e manifestação da sociedade que expressa todas as contradições geradas e também contidas nas relações sociais de produção.

Na Geografia sempre se buscou compreender os processos de construção do espaço integrando as relações sociais em diferentes tempos produzindo e reproduzindo o espaço. Para isso, utilizava-se de conceitos e categorias de análises representando o espaço geográfico, paisagem, região, lugar, território e outros (SOUZA, 2005).

A principal preocupação da Geografia é conhecer o ambiente natural, a sociedade, o comportamento humano, as relações socioeconômicas e culturais. Pois, essa ciência está incansavelmente à procura de soluções que venham sanar questões no âmbito social, econômico e ambiental.

$\mathrm{Na}$ Geografia, o que interessa é saber onde ocorre o quê, suas causas e conseqüências, e também entender como se dão os processos de distribuição espacial dos fenômenos sobre a superfície da terra, e não o fenômeno em si (PEREIRA, 2000).

Mas, a principal função da Geografia é explicar a produção do espaço pela sociedade procurando mostrar suas desigualdades e contradições levando em conta seus interesses no tempo histórico, o que desencadeia sem sombra de dúvidas em uma transformação contínua.

Segundo GOMES (1990) a produção do espaço é um processo contínuo de construção de territorialidades espaciais em diferentes escalas geográficas envolvendo eternamente a relação interdependente homem-natureza e natureza-homem.

$\mathrm{Na}$ verdade, completa o autor, essa produção só é possível via trabalho produtivo/social materializados pela energia do ser humano como ser social ou como indivíduo, agente da produção e da transformação social.

Essa ciência é mais capacitada para fornecer os conhecimentos necessários sobre o ambiente natural e ação humana, possibilitando a análise das mudanças ocorridas e a intervenção de impactos ambientais. 
Historicamente as modificações ou transformações no meio inicialmente natural são ininterruptas desde antes da história da presença humana. O que nos mostra que este meio vem ao longo dos anos sofrendo alterações e gerando recursos dinamizados pelo trabalho mediado universalmente pela relação homem com a natureza.

O meio sofre alterações continuas simplesmente pela produção onde o homem habita evidenciando-se pela evolução das forças produtivas trazendo uma forma de apropriação e transformação do ambiente, que outrora era natural.

Nos tempos mais remotos da existência do homem as transformações se davam de forma natural sem nenhuma interferência drástica. Ou seja, o homem se apoderava da produção do meio sem modificá-lo, significativamente.

Para SANTOS (1996), hoje, ao contrário, com o surgimento de novas criações e aperfeiçoamentos de novos instrumentos e tecnologias, as quais são relacionadas e direcionadas pelas técnicas, o espaço geográfico é constantemente modificado e vem sendo produzido principalmente pela técnica, ciência e informação.

Esse autor ressalta que a existência do homem no meio é um fator novo na diversificação da natureza. E que este homem atribui um valor às coisas, o que no processo é acrescentado como uma mudança no dado social. Ou seja, a relação homem $x$ meio se resume em uma relação feita através do trabalho considerando-se uma condição fundamental de toda a vida humana.

Mas, sem dúvida todas estas transformações e modificações no meio trazem benefícios ao homem assim como prejuízos, e no caso processos de degradação do meio que vem quebrar seu equilíbrio natural. A tomada do espaço pelo homem com a desculpa social de organização deste espaço propicia o surgimento de vários problemas ambientais às vezes de difícil solução.

Segundo SANTOS (1996) a existência do homem na Terra é indiscutível com suas diversas formas de ocupação materializadas ou não buscam marcar sua presença. E é essa diversificação de ocupação que leva ao surgimento de problemas ambientais.

Esses problemas resultantes da ação do homem são possivelmente proporcionados pelo desenvolvimento tecnológico e a despreocupação com o meio ambiente. A exploração do meio por parte do homem tem como intuito apenas obter os recursos naturais como fonte geradora de capital, o que cria uma maior especulação da ocupação do espaço diminuindo o valor que lhe é atribuído. 
Os vários interesses exploratórios do homem em relação ao espaço sem o prévio conhecimento da complexidade do meio geográfico podem, por vezes, desencadear desastres irreversíveis ao meio e ao próprio homem ou a sua descendência futura.

Estes desastres no meio vêm se acelerando com mais intensidade principalmente com o advento do desenvolvimento de novas tecnologias. Quando se pretende modificar o meio é necessária uma análise no conjunto dos componentes naturais e sociais, sem falar em suas próprias relações que manifestam na realidade.

O meio ou a natureza devem ser analisados e entendidos em seus processos de formação e transformação antes de serem apropriados ou modificados. Sem isso, não podemos ter base para aplicação de um processo de apropriação na natureza, sem que haja danos e prejuízos como a sua própria degradação.

É de suma importância o conhecimento prévio das potencialidades dos recursos naturais de um espaço para a sua ocupação. Dentre elas se destacam o solo, a declividade, o relevo, a geologia, a rede hidrográfica, o clima, a vegetação. Pois, a natureza é formada por seus componentes físicos, bióticos e sócio-econômicos.

Para a Geografia o meio ambiente é um objeto geográfico de estudo, onde este foi transformado e modificado pelo homem. ROSS (1998) enfatiza que o interesse da Geografia é aprender como cada sociedade humana estrutura e organiza o espaço físico-territorial em relação às imposições do meio natural contra a capacidade técnica, o poder econômico e os valores socioculturais.

O meio ambiente estudado pela Geografia agrega a sua dimensão histórica, além de sua relação intrínseca com a sociedade. NOAL (2001), diz que o meio ambiente é a natureza transformada historicamente pela cultura.

Existem muitas discussões de diversos autores renomados em relação às bases teórico-metodológicas sobre o estudo do meio ambiente na Geografia a partir da evolução do pensamento geográfico. Desta forma, optando pela postura advinda com a contribuição da Teoria Geral dos Sistemas às ciências, faremos uma reflexão da abordagem sistêmica culminado com o estudo dos geossistemas.

A natureza deve ser estudada como um conjunto integrado de elementos, onde se encontra inserido o homem. Ou seja, a natureza é um sistema natural defendido já por von Humboldt, o qual expõe sua teoria na obra chamada "Cosmos". Ai se encontra o início das concepções dinâmicas sobre o meio ambiente (HARTSHORNE, 1991).

Para Alexander von Humboldt, citado por NOAL (2001) a Geografia era como a parte terrestre da ciência do Cosmos. Na verdade, era vista como uma espécie de síntese de 
todos os conhecimentos relativos à Terra preocupada com a interação entre os elementos e tentando buscar nesta interação a causalidade existente na natureza (empirismo raciocinado).

$\mathrm{Na}$ idade média a relação do homem com a natureza era estudada através da descrição minuciosa da forma como essa natureza interagia com o homem. Tanto que para a Geografia Tradicional essa relação destacava três abordagens principais: a Determinista, a Possibilista e a Ecológica.

$\mathrm{Na}$ Determinista, o homem tinha suas ações condicionadas aos fatores naturais e a Geografia era a ciência que tratava desta influência. Já na Possibilista, o homem sofria influência do meio apesar de suas possibilidades em intervir e a Geografia seria a ciência engajada em estudar esta ação em relação à transformação desse meio. $E$ finalmente a Ecológica, onde a Geografia teria o desafio de estudar a relação homem x meio com o mesmo peso ou valor, ou seja, percebendo e considerando seus próprios equilíbrios entre si.

A concepção do Determinismo foi trazida para a Geografia por Ratzel (ANDRADE, 1987; MORAES, 1994) que defendia que a relação homem x meio era determinada eminentemente pela natureza. Para este autor o homem inserido no meio tentava apenas sobreviver, adaptando-se a ele. E nesta concepção, a preocupação da Geografia era somente com a caracterização dos aspectos naturais da superfície da Terra dando ênfase aos efeitos ocorridos nestes pelo desenvolvimento humano.

No Determinismo, onde o homem era senhor de seu meio surge como objeto de estudo a "região" advinda de uma síntese a partir do homem integrado ao meio (NOAL, 2001). Assim, com a contribuição feita por Paul Vidal de La Blache na Geografia, não existe somente a abordagem regional, mas também a divisão entre os elementos físico-naturais dos humano-sociais das paisagens.

A intenção de Vidal La Blache era executar uma obra coletiva denominada de "Geografia Universal" com a criação do objeto de estudo "região". Caberia à Geografia a identificação das regiões do globo humanizando, conceito o qual foi importado da Geologia.

MENDONÇA (2001) destaca que nem mesmo a proposta de Vidal de La Blache com sua análise regional (síntese do homem $x$ meio) conseguiu inter-relacionar o homem com o meio natural. O meio físico seria o principal fator de suporte para o desenvolvimento dos grupos humanos (o homem era o responsável pelo meio), onde nenhum dos elementos se relacionava (elementos físico-naturais $\mathrm{x}$ elementos humano-sociais das paisagens).

A concepção proposta por Vidal de La Blache estabeleceu uma Escola Francesa de Geografia, trazendo para a França um arsenal de discussões geográficas. 
Em MORAES (1994) descreve-se que desde a concepção de Vidal de La Blache diversos autores como: Sorre, Le Lannou e Cholley seguiram sua mesma abordagem regional levando a uma concretização do estudo de uma Geografia Humana. Nesta, se dava ênfase aos fenômenos estritamente humanos como: a humanização do meio, a organização humana do espaço, entre outros aspectos antrópicos relacionados com o meio.

Já na abordagem do Positivismo nos deparamos com a transição do processo histórico Monárquico para o Burguês, a qual foi o responsável pela origem ideológica desta. Onde havia a concepção de um corpo social unificado e politizado incorporado definitivamente no meio cientifico (NOAL, 2001).

Desta forma, o Positivismo foi se desenvolvendo ao ponto de se tornar um resumo de progresso das ciências naturais com ênfase nas biológicas e fisiológicas. Pois, segundo MORAES (1994) a principal unidade do pensamento geográfico tradicional era concretizada a partir do fundamento comum relacionado ao positivismo manifestado de uma forma geral e enraizada no contexto empírico e naturalista.

A filosofia do Positivismo englobava uma vasta compreensão sobre os fenômenos existentes no mundo real. Para TRIVIÑOS (1987) se considerava ideologicamente uma unidade metodológica de investigação a partir de informações naturais e sociais. Onde, tanto os dados naturais como sociais eram regidos por normas invariáveis. A principal preocupação era atingir as metas necessárias para se alcançar os objetivos que se pretendia.

Assim, iniciavam-se inúmeras investigações científicas que constituíam as bases do pensamento geográfico, a Geografia. Na verdade, filosoficamente tratava-se da busca do entendimento de todos os fenômenos universais pelos métodos empíricos ou de verificação experimental. Onde para FERREIRA e SIMÕES (1990) o estudo dos fatos e de suas relações advindas da percepção dos sentidos exteriores (observação direta) era à base fundamental do conhecimento. De forma tal que se inicia a possibilidade de levantar hipóteses, fazer deduções e formular leis.

A filosofia Positivista enraizada em profundos estudos apoiou a denominada "Geografia Tradicional". A qual foi predominante em um cenário da Ciência Geográfica por longos anos gerando novos estudos e consequentemente um desenvolvimento natural de qualquer ciência.

A Geografia Tradicional trouxe inegáveis contribuições como a elaboração de grandes conhecimentos responsável pela sistematização da ciência, investigações centradas em um campo específico, respaldando a autonomia da ciência, construção de um 
grande acervo empírico, fonte para constantes pesquisas, desenvolvimento de técnicas de representação e descrição, entre outros (NOAL, 2001).

Com o advento da Segunda Guerra Mundial, a Geografia deixou a postura positivista devido às inúmeras transformações ocorridas naquela época e mergulhou em um novo período chamando Neopositivismo ou Positivismo Lógico. A complexa realidade contemporânea não era mais entendida pelas análises simplistas da Geografia naquela época, surgiam novas formulações analíticas e de explicação do real.

Desta forma, o Neopositivismo origina uma Nova Geografia, onde a mesma embasada pelo desenvolvimento da Física de Newton explica e torna compreensível que os fenômenos ocorrem sem uma determinação específica. Ou seja, adotando uma importância relacionada à probabilidade e não a relação determinista de causa-efeito.

A partir desta nova postura surgem novas abordagens teórico-metodológicas que culminaram nessa Nova Geografia denominado-a de "Quantitativa" ou "Pragmática“. A qual teve origem pelas influências do Neopositivismo sobre a análise geográfica nos Estados Unidos e expandindo-se à Grã-Bretanha, aos países nórdicos (Suécia) e, depois chega ás escolas geográficas européias (NOAL, 2001).

A Geografia Quantitativa ou Pragmática gerou sérias reflexões acerca dos diversos conceitos aceitos pela comunidade de geógrafos desencadeando uma verdadeira guerra com a chamada "revolução quantitativa". Para essa comunidade era o rompimento de uma estrutura tradicional em contrapartida a utilização de modelos e da teoria dos sistemas, ou seja, surge uma "Geografia Sistêmica" ou "Modelística".

MORAES (1994), com base nesta Nova Geografia utiliza em suas pesquisas todo o instrumental quantitativo, sistêmico e modelístico. Para a geração de um tipo de conhecimento unicamente operacionalizável que advém da intervenção deliberada sobre a organização do espaço.

Assim, a Geografia Sistêmica ou Modelística tem o intuito de explicar os fenômenos pela aplicação de leis e também da padronização delas. Tornando-se uma ciência formuladora de leis na busca do conhecimento sobre a distribuição destes fenômenos na superfície da Terra. O que veio a gerar incríveis transformações em todas as formas de conhecimentos antes estudadas, onde o capitalismo monopolista, a revolução tecnológica e o fim do liberalismo ocasionam uma maior ação estatal na economia e na necessidade de planejamento.

Com o alicerce desta Nova Geografia, a Geografia Física se torna mais evidente desenvolvendo-se assim, neste ramo, os estudos do meio ambiente. Pois, em seu quadro evolutivo durante a primeira metade do século XX, a predominância da Geografia Física era Rodríguez, A. C. M. 
de uma fase mais analítica caracterizada por estudos específicos, onde a biogeografia, climatologia, geomorfologia, hidrografia e pedologia tinham sua concepção individual como ciências autônomas.

CHRISTOFOLETTI (1981) completa que com todas estas transformações da evolução da Geografia Física foi inevitável uma grande "crise geográfica", a qual gerou contradições dicotômicas apontando questionamentos decorrentes dos conceitos da definição de Geografia, por conseguinte da dubiedade entre Geografia Humana e Geografia Física e, entre a Geografia Geral e a Geografia Regional.

A Nova Geografia se aprimora na virada da década de 50 e se moderniza com o uso de novas tecnologias a partir dos processos de computação e digitalização. Na verdade evolui com a Teoria Geral dos Sistemas de von Bertalanffy por se acreditar num grande avanço tecnológico e científico para a Geografia naquela época.

O novo avanço do conhecimento geográfico deixa para o passado os estudos especializados, setorizados e individualizados. Onde, a Nova Geografia que tratava das organizações espaciais, empenha-se agora na valorização aos estudos integrados dos fenômenos geográficos, em especial do meio ambiente. E assim, a busca de uma abordagem metodológica era necessária para compreensão destes objetivos sobre o estudo do meio ambiente, como a denominada "unidade funcional básica da geografia".

Desta forma, a Teoria Geral dos Sistemas teve grande influência nos estudos da Geografia pelo surgimento do conceito de ecossistemas no caso dos estudos ambientais. E logo depois desencadeou a criação de uma abordagem própria da Geografia com o novo conceito de geossistemas (NOAL, 2001). Que para ODUM (1988) se tratava de uma unidade de estudo do meio ambiente, onde os organismos bióticos (vivos) e abióticos (não vivos) existentes neste meio são capazes de se relacionarem e interatuarem entre si.

O ecossistema era o conceito utilizado para se estudar o meio ambiente desenvolvido pelos biólogos na década de 30 . O que foi uma grande vitória não só para a biologia, mas para toda e qualquer ciência ligada ao meio ambiente. E para a Geografia era o inicio da possibilidade de entendimento ou análise integrada da natureza, o que representava uma unidade de estudo para o meio ambiente.

Com o surgimento deste novo conceito foi possível integrar conhecimentos de várias ciências como a Biologia, a Ecologia, a Botânica e Zoologia com o objetivo de se estudar o meio ambiente ou conjunto ecossistêmico.

TRICART (1977) faz a apologia que o ecossistema só foi um motivo a mais para as ciências se unirem em um bem comum, o meio ambiente. Pois, a integração destas ciências 
anteriormente isoladas e dispersas em vários livros de botânica e zoologia começava a ter sentido como parte integrante de um todo (conjunto de fenômenos).

Esse autor completa que os estudos do ecossistema visaram um entendimento dos problemas ocorridos no meio ambiente, e também desenvolveram novas pesquisas no sentido de tentar resolve-las.

TRICART (1977) afirma ainda, que para a Geografia não há métodos próprios, porém métodos de aplicação muito mais gerais advindos de um grande grupo de disciplinas. Dando ênfase ao que MENDONÇA (2001) defende, onde o fato de a Geografia fundir os resultados utilizando métodos de um arsenal de outras ciências faz dela uma ciência de relações não só do homem com o meio, mas também da sociedade com a natureza.

Desta forma, o ecossistema tratava do estudo das interações dos fatores bióticos e abióticos seguido da organização entre os seus componentes. Onde o homem era o único fator que faltava incluir, assim como a especificação da dimensão de uma territorialidade para a abrangência deste ecossistema.

Para BERTRAND (1971) o ecossistema não apresentava uma escala e nem suporte espacial bem definido podendo ser qualquer tipo de meio como um oceano ou pântano ou um tronco de arvore tombado em decomposição numa floresta. Logo, para os geógrafos não se tratava de um conceito geográfico gerando assim uma série de criticas sobre o conceito de ecossistema para a Geografia.

Já TROPPMAIR (1983) enfatizava que nas ciências da Biologia e Ecologia o ecossistema era especificamente analisado sob o ponto de vista vertical totalmente diferente da análise horizontal da Geografia. A qual estudava os componentes do ecossistema dando importância a sua distribuição, estruturação e organização espacial.

Desde então, o conceito de ecossistema foi se aprimorando através das pesquisas e analises dentro da Geografia culminando com o surgimento de uma nova concepção metodológica nos estudos ambientais, o "Geossistema". Este foi proposto inicialmente na década de 60 por SOTCHAVA buscando entender os processos físicos que ocorriam no planeta (SOTCHAVA, 1976).

Para a Geografia Física, o Geossistema era seu ponto de base de estudos sobre o meio ambiente. Mesmo que ainda com um pé no Positivismo e se distanciando da inclusão do homem, ou melhor, inserindo ai a ação antrópica como mais um elemento de análise neste atual sistema (MENDONÇA, 2001).

Em MONTEIRO (2000) se nota nitidamente às contradições e diferenças entre os dois conceitos, o de ecossistemas e o geossistema de SOTCHAVA. Os quais de forma 
nenhuma são igualitários quer na Geografia, quer na Ecologia. Mas, para a Geografia o geossistema tem um apreço mais enraizado devido aos aspectos de interesse da Ciência Geográfica totalmente voltada para a organização do espaço.

O geossistema definido em BERTRAND (1971) descreve uma paisagem nítida e bem circunscrita que pode ser identificada sem nenhum problema nas fotografias aéreas (instantaneamente). Este conceito vem a ser uma unidade dimensional entendida por alguns quilômetros quadrados. E é nesta escala de estudo que ocorrem diversos fenômenos de interferência entre elementos da paisagem e que evoluem, com a presença do homem, para as combinações dialéticas importantes para o geógrafo.

$\mathrm{Na}$ estruturação do esboço metodológico para o geossistema, o autor acima mencionado, estabelece seis níveis temporo-espaciais: zona, domínio, região natural (níveis superiores), geossistemas, geofácie e geótopo (unidades inferiores).

Nos níveis superiores do geossistema a atuação do relevo está junto do clima com o auxílio das grandes massas vegetais. Onde, o autor considera como geossistema o resultado da interação de fatores geomorfológicos (rochas, declive, manto superficial, dinâmica das vertentes entre outros), fatores climáticos (precipitação, temperatura, entre outros) e fatores hidrológicos (lençóis freáticos e nascentes, tempo e déficit hídrico nos solos (ressecamento) entre outros).

O geossistema faz parte de um potencial ecológico que engloba a geomorfologia, o clima e a hidrologia baseada na construção do conceito pela exploração biológica do espaço (vegetação, solo e fauna) seguida da ação antrópica. E todos estes processos se interagem ou se transformam ora pela ação natural, ora pela humana trazendo diversas transformações ao meio mostrando seu típico caráter dinâmico.

Desta forma, o geossistema assume um sistema natural e homogêneo abraçado por uma territorialidade que se caracteriza por alguns aspectos importantes como (CHRISTOFOLETTI, 1981): a morfologia que representa as estruturas espaciais verticais e

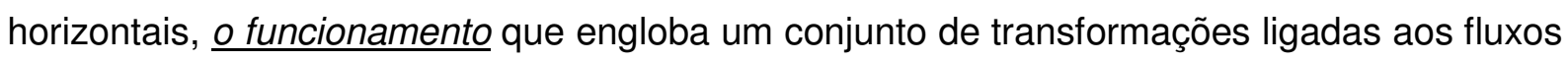
de matéria e energia (processos) e o comportamento específico que trata das mudanças de estados que ocorrem no geossistemas em determinada seqüência temporal.

O geossistema vem a corresponder a uma unidade no espaço delimitada por determinada ordem de grandeza expressa pela organização espacial. Onde, toda sua estrutura é refletida por processos atuantes durante seu funcionamento e por sua historia MONTEIRO (1987).

A abordagem geossistêmica leva em consideração apenas os estudos ambientais com base na Geografia Física, deixando de lado a sociedade (homem) como componente Rodríguez, A. C. M. 
do processo. Porém, a importância desta é dada apenas quando se trata de impactos antrópicos no meio, pois a relação homem x sociedade é vista separadamente no meio.

Além, desta concepção de SOTCHAVA pelos estudos ambientais na década de 60, outras abordagens de cunho cientifico apareceram como a denominada "Geografia Crítica" formulada por MORAES (1994). A qual dava ênfase aos problemas sociais devido aos diversos conflitos raciais e movimentos ecológicos decorrentes do avanço do capitalismo imperialista durante a Guerra do Vietnã (NOAL, 2001).

A Geografia Crítica baseada no fundamento filosófico tinha o materialismo histórico e dialético como centro dos estudos na produção do espaço. Pois, sua principal preocupação era com a busca por explicações coerentes, lógicas e racionais quanto aos fenômenos da natureza, sociedade e do pensamento. Onde, segundo TRIVIÑOS (1987) tais respostas estavam baseadas na ciência filosófica do marxismo que estuda as leis sociológicas que caracterizam a vida da sociedade, de sua evolução histórica e da prática social dos homens, logo no desenvolvimento da humanidade.

No materialismo histórico a interpretação da realidade é vista de forma bem difundida com apresentação de novos conceitos na Geografia como ser social, meios, relações e modos de produção, etc. E para o materialismo dialético se vê outros aspectos que envolvem o movimento universal e as conexões existentes entre eles como: a organização inter-relacional entre sociedade e natureza.

Desta forma, a Geografia Crítica é considerada uma ciência que estuda o espaço em sua totalidade, não havendo formas de estudos por divisões em partes menores. Para SANTOS (1985) o espaço é social e o mesmo não é formado apenas por coisas, objetos geográficos, naturais e artificiais, os quais em conjunto formam a natureza. O espaço é a somatória de todos estes elementos e mais a sociedade, e cada fração da natureza corresponde a uma fração da sociedade atual.

SANTOS (1996), então, diz que o estudo dessa Nova Geografia se dá a partir do entendimento das relações da sociedade com a natureza. Ou seja, da ação do homem sobre o meio constituído por objetos naturais e artificiais, os quais originam a produção do espaço. Este autor destaca o espaço como um conjunto indissociável de onde participam de um lado certos objetos geográficos naturais e sociais e, de outro a vida que os preenche e os anima, a sociedade.

A colocação de SANTOS (1996) mostra que a realidade é entendida na Geografia Crítica através de uma abordagem dialética, onde a mesma parte de contradições e de uma permanente transformação. Nesta abordagem são considerados os problemas sociais que 
visam uma transformação da realidade e uma construção mais justa da sociedade procurando desmistificar essa realidade e apreender a dinâmica atual do espaço social.

Logo, o estudo do meio considerado como principal objeto central que existia externa ás atividades do homem numa tradição positivista se vê a partir do materialismo histórico e dialético um processo unificado e não-contraditório da natureza. Pois, segundo GOMES (1990) o estudo das relações homem x meio são vistas interdependente no espaço e tempo geográfico resultante de seu trabalho social transformando-as continuamente numa única natureza.

Para a Geografia as duas abordagens: a das questões ambientais advinda da tradição Positivista, onde a natureza era separada da sociedade e a das relações homem $x$ $\underline{\text { meio }}$, onde existe o materialismo histórico e dialético resultando em uma abordagem unificada e a favor da natureza, têm seu propósito direcionado ao que se quer alcançar de metas ou objetivos. Mas, dentro das questões ambientais a natureza tem seus preceitos garantidos tendo em vista sua reciprocidade à história da humanidade.

Foram as transformações e modificações do homem que tornaram essa natureza em uma segunda natureza com a intenção de produção de recursos indispensáveis à sua própria existência perante a sociedade. Onde, a apropriação da natureza e o acesso dos diferentes grupos sociais aos recursos naturais são vistos como fatores resultantes de própria produção do espaço.

Observamos que não existe separação entre o homem e a natureza. Pois, o homem é natureza e a única separação que podemos lembrar é seu condicionamento aos processos sociais históricos.

Em MENDONÇA (2001) se observam nitidamente que nas questões sociais da Geografia Crítica existe pouca abordagem do suporte físico-territorial devido a sua exclusiva proximidade com as ciências da sociologia, história e da economia política. Ou seja, a limitação dessa geografia com as questões ambientais é clara, assim como o caráter geográfico marcante sem nenhuma abordagem da sociedade na Geografia Física.

Este autor completa que na Geografia Humana a produção prática de pesquisas referente à temática ambiental é ínfima, se restringindo unicamente as questões de cunho teóricas. Assim, a importância de uma reflexão acerca destas ciências no sentido de superar tais impasses e construir um processo de renovação sobre os estudos relacionados do homem com a natureza trará inigualáveis avanços nos estudos geográficos.

Segundo SANTOS (1996) o homem após um processo evolutivo de estudos e pesquisas em fim toma conhecimento sobre a presença das coisas na natureza e inicia a 
utilização destas de forma geral e global. Esta nova visão sobre a natureza pelo homem renova as bases de conhecimento nas ciências.

E por isso, o autor ressalta, é necessária também que as disciplinas envolvidas nestes estudos se renovem. Onde, a Geografia perceba todas estas perspectivas atuais e possa transmitir sua capacidade de trabalhar com as leis universais consolidando perante toda a comunidade de cientistas geográficos a existência de uma "Geografia Global".

Para CONTI (1997) os geógrafos físicos são considerados Deterministas por se preocuparem apenas com a natureza e por isso são injustiçados. Mas, ele nega que os geógrafos se esquecem que existe a interferência do homem no meio como agente transformador do espaço.

O homem é considerado nesta ciência um agente transformador quando existem relações dentro da sociedade estabelecidas por ele vindo a produzir e transformar o espaço. Pois, é a sociedade quem é a responsável pela organização do espaço pela simples utilização dos recursos disponibilizados no meio.

Em vista da abordagem do materialismo histórico e dialético, a questão ambiental é baseada por processos sociais, pois a mesma produz um espaço social e que só é viável pelas relações sociais históricas determinadas. Logo, o ambiente deve ser entendido porquanto como recurso, condição essencial para a produção, mercadoria e objeto de intervenção do Estado (GOMES, 1991).

Para o autor, a produção do espaço é um contínuo processo de construção de territórios espaciais com diferentes escalas geográficas e cuja relação é interdependente homem x natureza e vice-versa. Ou seja, a produção deste é viável via trabalho produtivo/social materializado pela energia do próprio homem como ser social e como indivíduo, agente de produção e da transformação social.

GOMES (1991) explica que a produção do espaço tem haver com homens trabalhando e produzindo seus bens sociais para nossa vida diária, definindo-se assim em cada momento de produção uma determinada dimensão social no sentido de obter em termos de espaço social e natural a tal sobrevivência comunitária.

Logo, o homem é o principal beneficiário da produção deste espaço social transformador do meio. Onde, o cenário das atividades humanas compreende a base que nutre a dualidade ente a Geografia Humana e Física, pois estas separam quem constrói o espaço dessa mesma produção. Ou seja, o entendimento do espaço se aplica na integração daquilo que contém com seu conteúdo (SCHAEFER, 1980). 
Para SANTOS (1996) não há separação entre Geografia Física e Humana. E nem mesmo existe Geografia Física que não esteja dentro de uma Humana. Assim, neste contexto o que existe é uma Geografia do homem que pode ser dividida em Geografia Física e Humana. Onde, o homem se beneficia no final dos principais avanços das ciências.

Para a Geografia o importante é o estudo do conceito de "meio geográfico", já que o mesmo envolve os elementos naturais e sociais, assim como as relações estabelecidas entre ambos (CHOLLEY, 1964; ISNARD, 1982; SANTOS, 1996; 1997). Este conceito compreende os processos de transformação no espaço/tempo que na verdade trata da constituição de um meio socialmente produzido.

SANTOS (1997) ressalta que o termo "meio geográfico" foi criado e este viveu por milênios como meio natural ou pré-técnico. O qual foi denominado como meio técnico ou maquinário durante dois a três séculos e hoje é considerado como meio técnico-científicoinformacional.

Desta forma, para que possamos entender melhor a realidade do meio geográfico necessitamos identificar os padrões de distribuição espacial ocorridas no meio. $E$ na Geografia utilizamos a linguagem da representação gráfica em Cartografia para explicitar ou representar visualmente essa realidade.

A Geografia nasceu junto a uma tradução do meio geográfico com o intuito de se conhecer, entender e estudar esse meio. Para analisar a geografia de qualquer meio necessitamos da inclusão dos produtos cartográficos, os quais melhor representam as formas do espaço geográfico. E os mesmos são capazes de registrar e armazenar as informações prioritárias no apoio ao planejamento ou gestão deste espaço para a sociedade.

Mas, antes de discorremos sobre a Ciência Cartográfica falaremos da Ciência Agronômica, a qual também realiza a observação do espaço ou meio geográfico como a Geografia, porém em prol da agricultura. Esta ciência estuda os problemas físicos, químicos e biológicos do meio. Sua atuação se resume na transformação do meio natural num meio adequado para a produção de vegetais e de animais no subsídio à sobrevivência do homem em sociedade.

\subsection{AGRONOMIA}

A palavra Agronomia na etimologia vem do grego "agronomos" e significa o estudo científico dos problemas físicos, químicos e biológicos em prol da agricultura. Por sua vez a palavra Agricultura tem origem no latim "agricultura" (ALMEIDA, 2000). 
O profissional da Agronomia é o agrônomo que designava em Atenas o magistrado, responsável pela administração da periferia agrícola da cidade. A palavra agrônomo foi amplamente traduzida em várias línguas culminado no século XVII nos países da Europa e França, passando a ser escrita nos dicionários como sendo o "técnico que entende de agricultura" ou "aquele que escreve sobre agronomia".

Desde então, outros significados ou termos foram surgindo como o de "agricultor físico", onde físico era concernente a aquele que estuda cientificamente a natureza. E durante a revolução francesa, tanto o termo agrônomo como o de engenheiro agrônomo foi amplamente divulgado. Mas, somente em 1848 a agronomia desponta oficialmente na Europa com a fundação do Instituto Nacional Agronômico de Versailles (1848-1852).

Essa consolidação do agrônomo ainda era muito aquém de suas atividades agrícolas exercidas hoje, pois o mesmo era reconhecido apenas como um intelectual que escrevia textos técnicos, científicos, econômicos ou administrativos sobre agricultura (ALMEIDA, 2000).

A Agronomia se destaca pelo surgimento da Agricultura que apresenta uma definição sintética e expressiva proposta por René Dumont, a qual é a "artificialização" pelo homem do meio natural com fim de torná-lo mais apto ao desenvolvimento pelo melhoramento de espécies vegetais e animais (BARROS, 1975).

Este conceito de "artificialização" envolve uma série de técnicas culturais inerente ao seu grau de aplicação. De forma que a definição do que vem a ser Agricultura prende-se com complexidade as atividades humanas, as quais são advindas de um determinado momento histórico, de um ambiente natural e principalmente de um contexto social.

Para DIEHL (1984) a Agricultura consiste no esforço para situar a planta cultivada nas condições ótimas de meio (clima, solo) para lhe tirar o máximo rendimento em quantidade e em qualidade. Na verdade, trata-se de uma definição com origem capitalista que visa em primeiro lugar o lucro e não o máximo rendimento para assegurar a sobrevivência.

Este mesmo autor apresenta ainda outra definição que transforma a Agricultura em arte de obtenção do solo procurando sempre a manutenção de sua fertilidade visando à aquisição de máximo lucro. Novamente vemos um sistema capitalista de produção escondida por trás da obtenção de produções regulares ao longo dos anos buscando a sua sustentabilidade.

A Agricultura se apresenta em cinco fases distintas no mundo, segundo ALMEIDA (2000), a primeira fase é apresentada como o período de sobrevivência humana na terra 
utilizando práticas de coleta, caça, cultivo primitivo com o uso de queimadas resultando em desmatamentos.

Já a segunda fase vem desde o neolítico com o aparecimento de uma agricultura mais ou menos organizada que privilegia um número pequeno de nobres e do clero. Em contrapartida com a inclusão de mão-de-obra escrava ou serva sob condição social direcionadas na produção agrícola de glebas.

A terceira fase marcada ainda na Idade Média representa o inicio da presença dos verdadeiros agricultores que adquirem concessões de unidades agrícolas pela Igreja ou por senhores feudais. Assim, a independência agrícola tem um novo rumo e é caracterizada pelo surgimento da tração bovina e equina de grande tradição na Antiguidade.

Agora, a quarta fase ocorrida entre o final do século XIX e todo o século XX dá margem às teorias econômicas substituídas da economia rural. As quais tinham uma lógica de rendimento financeiro (capitalista) ou política (socialista) provendo a acumulação de capital por uma sustentação na economia de consumo de massa.

E a quinta fase marcada no final do século XX faz aparecer o "novo ideário agronômico" com a tendência de transformar a agricultura de nível nuclear ou familiar em uma mais global, no âmbito de Estado. Surge então uma preocupação com a gestão, conservação e recuperação do meio ambiente global despontando uma nova área a "Ecologia".

A Ecologia tem um direcionamento para o estudo da concepção da ação do homem sobre seu meio ambiente. O que amplia o leque da agricultura dentro de uma agronomia global preocupada com as relações das pessoas com seu ambiente natural.

Mas, o advento da Ecologia dá espaço ao surgimento do tema teorização agronômico que é baseada apenas em modelos prescritivos e normativos criada nos "Cursos de Agricultura" por Adrien de Gasparin (1848). Os quais eram alicerçados por contribuições da física, biologia e química, mas de conhecimentos ainda fragmentados e analítico-experimentais, onde os elementos solo, planta e clima eram estudados separadamente e em condições particulares.

Os estudos e pesquisas realizados sobre a essa teorização desenvolveu uma Química Agrícola a partir de LIEBIG (1840) deixando marcas bem perceptíveis até os dias de hoje. Mas, durante a metade do século XX surgem também a Fisiologia Vegetal influenciável crescentemente nos processos agronômicos.

Em 1960, na Europa as pesquisas sobre a instabilidade estrutural dos solos rompem a antiga teorização sobre a independência dos elementos solo, planta e clima. Então, a 
visão normativa e setorial é substituída por uma abordagem global e teorizada do conjunto população vegetal, solos, clima e técnicas de cultivos coordenados por observações e coleta de dados de uma construção intelectual. Assim, surge a Agronomia Moderna.

A Agronomia Moderna iniciada por S. HENIN em 1840, discípulo de BACHELARD, insere novos métodos agronômicos de grande impulso que se baseiam em três eixos, a saber: a) a Experimentação; b) a Observação e o acompanhamento de situações controladas; e c) a Análise e Diagnóstico de situações regionais.

RENÉ DUMONT é o agrônomo marco em relação à Análise e Diagnóstico de situações regionais desde o final do século XIX. Pois, o mesmo desenvolveu novos métodos com intuito de facilitar a compreensão das técnicas agrícolas de visão global de exploração buscando uma tecnologia agrícola comparada aos tempos atuais como segmento da Agronomia Mundial (ALMEIDA, 2000).

O surgimento da Ecologia na Agronomia Moderna aflorou uma abordagem globalizante e ampliou nesta ciência uma "ecologia aplicada à produção das populações de plantas cultivadas e ao melhoramento dos solos agrícolas" (DEFFONTAINES, 1992).

Desta forma, a Agronomia toma duas linhas de pesquisas por dois ramos distintos: 1) o conhecimento sobre os mecanismos inerentes ao sistema planta, solo e clima e 2) $\underline{0}$ conhecimento básico e especializado adquirido pelas disciplinas como: Fisiologia Vegetal, Bioclimatologia e a Pedologia.

Estas duas linhas provocam uma nova visão da Agronomia na "ciência de um conjunto complexo de fenômenos ligados entre si e cuja exteriorização (via campo) é subordinada à dependência de um fator aleatório, o clima (DEFFONTAINES, 1992). A qual era oposta a formulação restritiva de HENIN (1967) definida por um ponto de vista Ecofisiológico na Agronomia.

DEFFONTAINES (1992) também sugere outra linha dada à pesquisa e ao interesse agronômico, a qual conta com intervenções técnicas e aos objetivos dos agricultores como "uma abordagem simultaneamente diacrônica e sincrônica das relações no interior de um conjunto constituído pela população vegetal, o clima, o solo e submetido à ação do homem em vista de uma produção".

A influência desta linha na década de 1970 provoca uma perspectiva muito próxima, a qual se refere ao interesse pela diversidade local e regional das condições de produção e de melhoria dos solos. Onde esse mesmo autor define como "análise descritiva e explicativa de fenômenos (técnicos) agrícolas observados em áreas geográficas variadas com o intuito de esclarecer os processos de adoção de inovações técnicas". 
A definição apresentada sugere o realce do conhecimento e da compreensão das múltiplas modalidades e das intervenções técnicas colocadas em prática pelos agricultores em meios ambientes diferentes. Ou seja, ela introduz o que se pode considerar como uma finalidade de desenvolvimento (ALMEIDA, 2000).

No meio destes argumentos, constatações e avanços sobre esta ciência, os agrônomos tem duas funções principais: a) o avanço na elaboração do corpus teórico da Agronomia que gerou uma teoria e b) a compreensão de situações, na realização de diagnósticos e na avaliação dos subsídios de ações que procuram a formulação de bases sobre as situações trazendo consequências de inegável valor para o profissional da área e seu desenvolvimento.

Para ALMEIDA (2000) o julgamento de uma ciência depende da referência de um corpus teórico, porém levando em conta a situação na qual se encontra aquele que age, além de seus objetivos. E dizer se uma dada função agronômica é ou não mais importante que outra, vai depender da origem de cada uma delas atualmente, as quais se apresentam nos últimos 30 anos.

Desta forma, com o exposto temos duas linhas, a saber: a da Ecofisiologia de plantas cultivadas (corrente analítica) com a população de plantas e o meio (clima e solo) como objetos científicos de base e a da Tecnologia Agrícola (orrente global ou tecnológica) com a técnica como fonte de base.

$\mathrm{Na}$ corrente analítica existe a definição das leis de variação dos estados da população e do meio por diversas técnicas de combinações. E o principal ponto de importância deste está na criação de modelos de rendimentos de diferentes cultivos por experimentação da parcela referente à sua forma de validação.

Já na outra corrente, a técnica não é apenas um fator de produção, mas é um resultado de produto de uma opção dependente da situação individual de dimensão social. ALMEIDA (2000) destaca nesta corrente a "Revolução Verde" que contribuiu bastante na afirmação desta, onde a experimentação do uso de fertilizantes é simbólica.

Vindo da confrontação destas duas correntes o antagonismo técnicas versus práticas, as técnicas podem ser analisadas, elaboradas, testadas e independem de quem as utilizam. Mas, as práticas não podem ser aplicadas sem estudo e sem considerar as condições nas quais vivem os agricultores. Ou seja, é necessária uma análise do contexto social, econômico e ecológico para as escolhas das melhores ações a serem tomadas.

Assim, não tem como a Agronomia não estar literalmente conectada as questões do meio ambiente com o intuito de tentar preservá-lo garantindo a sobrevivência do homem. 
Esta ciência tem como prioridade estudar, formalizar e conceber lógicas de ação técnica de produção vegetal com fins ao consumo humano, animal ou à transformação agroindustrial.

Esta ciência tem que estar constantemente preocupada não só com produção de alimento à população, mas também com os problemas ambientais surgidos advindos da produção em grande escala, localização, tempo/período entre outras na natureza.

A Agronomia, a partir do exposto, pode vim a ser definida pela direção de suas práticas agrícolas reforçando sua dependência em relação ao processo dinâmico de funcionamento das populações vegetais cultivadas e do meio biofísico. A mesma pode ainda fazer uso de conhecimentos originários da Agro-fisiologia, da Pedologia e da Bioclimatologia, além de buscar conhecimentos nas ciências de Gestão, Economia, Sociologia e Antropologia.

O dualismo das ciências agronômicas está reflexionado na técnica versus prática a partir das discussões acima. E nos leva a um método de análise in situ, onde surge uma nova linha: a das pesquisas/diagnósticos de situações definidas (ALMEIDA, 2000).

Nesta nova linha, vemos que a Agronomia se torna mais aplicável globalmente pelo funcionamento de sistemas técnicos de cadeias agroalimentares, em unidades de produção agrícola por cooperativa de uma comunidade, de uma grande ou pequena região na solubilidade de problemas identificados por agentes de desenvolvimento.

Com isso é impossível o não uso de pesquisas multi e interdisciplinares que busquem uma ação mais imediata no comando da gestão técnica individual ou coletiva. No Brasil e no Mundo apesar de minoritários, a aplicação de duas disciplinas como uma Economia-Agronomia ou Sociologia-Agronomia, por exemplo, geram sem dúvida um melhor direcionamento a uma Agronomia Gestacionária.

Ao nos referimos sobre esta nova linha, não podemos deixar de ver a influência de uma abordagem sistêmica acompanhada da dimensão ecológica nos processos produtivos. E atrelada a isso surge a Agroecologia preocupada com a pesquisa agronômica no resgate dos valores de conservação e preservação dos recursos naturais, na distribuição equitativa de recursos do social que visa apenas a produção e o consumo de um pensamento sistêmico das coisas (ALMEIDA, 1998; 1999).

A Agronomia passa a ter uma abertura maior nas questões de reflexão multi e interdisciplinar. Não que ela tenha se fechado para seus conhecimentos próprios, mas surge a presença incontestável do ser social junto a uma tecnologia agrícola. O que trouxe influências interdisciplinares como, por exemplo, as ciências sociais e humanas, biológicas e da terra. 
Desta forma, com o exposto percebemos que Agronomia está presente juntamente com outras disciplinas na busca de solucionar situações relacionadas ao campo estrito da Agronomia. Sem esquecer que ela também está envolvida em outras áreas devido sua complexidade nos componentes que interferem e determinam um sistema agrícola e agrário.

A dependência observada nesta disciplina nos cria duas direções distintas: uma ligada à demanda social e outra com finalidades específicas advindas de situações particulares. As quais se localizam numa interface que intervêm na atividade humana.

A Agronomia com relações que estabelecem um território específico de elementos representados por agricultores, projetos agrícolas e o meio ambiente de fatores econômicos, sociais e naturais apresentam legítimas informações originais que aportam e levantam questões relevantes para uma infinidade de outras disciplinas.

ALMEIDA (2000) descreve que a Agronomia relacionada juntamente com a sua interdisciplinaridade pode apresentar algumas idéias ou iniciativas metodológicas preliminares como: 1) o Perfil de cultivo, 2) a Uso ou Utilização das terras, 3) as Práticas agrícolas e 4) a Construção de uma Agroecologia.

A análise do Perfil de cultivo advém da teoria da evolução dos solos cultivados juntamente com os elementos funcionais da população vegetal, do solo, do clima e é claro das intervenções humanas. Possibilitando avaliações qualitativas ao enfoque sistêmico sob análise do conjunto solo da planta com as ações técnicas.

Neste método se torna fácil a observação de multilocais e dos estudos comparativos com o intuito de revelar a diversidade das práticas agrícolas, e assim aproximar o agrônomo do agricultor. E é neste ponto que a proximidade da Agronomia com outras disciplinas é evidente como na Geografia com sua noção de paisagem, na Sociologia com os seus sistemas agrários de dinâmicas sociais e produtivas, e também no desenvolvimento local.

Já o Uso ou Utilização das terras (D’AGOSTINI \& SCHLINDEWEIN, 1998) vem de encontro ao período industrial da agricultura devido ao grande desenvolvimento de insumos como fertilizantes, sementes melhoradas e outros visando o crescimento e atendimento ao rendimento de produção capitalista.

Esse método promoveu um aprofundamento nas pesquisas agronômicas acerca das potencialidades dos solos pela troca de conhecimentos de pedólogos, geólogos, bioclimatologista, fisiologistas em busca de intervenções de "fatores do meio". Enquanto que os "fatores técnicos" aproximavam a Agronomia dos conhecimentos em economia, sociologia e ecologia (ALMEIDA, 2000). 
As Práticas agrícolas estão intimamente ligadas à problemática do desenvolvimento rural, pois toda a inovação tecnológica se torna um fator limitante ao agricultor na aplicação de novos conhecimentos impedindo o progresso técnico. Remetendo-nos ao fundamento da etnologia que descreve uma atitude por parte da agricultura simplesmente de caráter cultural própria de uma sociedade.

Assim, neste método o agrônomo deve se apoiar em instrumentos práticos de um sistema solo/planta/clima que facilite o entendimento e compreensão em relação ao agricultor do progresso técnico.

E finalmente a Construção de uma Agroecologia que considera o uso potencial da diversidade social juntamente com os sistemas agrícolas no desenvolvimento local descentralizado privilegiando as relações sociais e biológicas ou ecológicas em cada meio.

Para NORGAARD (1989) este método pode descrever seis premissas:

a. os sistemas biológicos e sociais de potencial agrícola;

b. e esse potencial quando captado por agricultores tradicionais se submete a processos de tentativas, erros, aprendizado seletivo e cultural;

c. estreita ligação dependente entre os sistemas sociais e biológicos;

d. a natureza do potencial destes sistemas são melhor compreendidos em seu estado presente do conhecimento formal no social e no biológico;

e. todo esse conhecimento social e biológico formal, o conhecimento de alguns insumos advindos da técnica agronômica convencional, a experiência com instituições e tecnologias agrícolas resultam na melhoria destes agroecossistemas (tradicional e/ou moderno);

f. o respeito a todas estas premissas descritas possibilitam um melhoramento nas opções culturais e biológicas futuras dirimindo efeitos negativos acerca dos cultivos, a biologia e o meio ambiente.

A Agroecologia, neste sentido, se destina a apoiar e dar sustentação à transição dos atuais modelos de desenvolvimento rurais e de agricultura sustentável. E se baseia em idéias ambientais e de cunho social a respeito da agricultura.

A Agronomia, assim é descrita como uma disciplina a partir de dois pólos distintos de uma cadeia, onde de um lado existem os mecanismos fisiológicos, edáficos e climatológicos, e de outro as práticas dos agricultores. Esse cabo de guerra entre estes pólos são plausíveis de ruptura ou de uma complementação mútua (ALMEIDA, 2000).

Mas, se esta disciplina caminhar ao encontro das ciências sociais terá que estabelecer um contato mais íntimo com outras disciplinas afins para uma maior reflexão. 
Para a solidificação das interações tecnológicas juntamente com as do mecanismo sistema clima/solo/planta, assim como da conexão destas com as práticas agrícolas e do desenvolvimento.

Atualmente, a disciplina de Agronomia tem se mostrado bem astuta e resistente frente aos novos caminhos da agricultura em prol da produção agrícola para subsidio da população com a preocupação de conservação da natureza.

E mesmo sabendo deste grande desafio, a Agronomia se vale de novos conceitos ou talvez uma linguagem nova com regras e métodos para a busca de uma das mais árduas tarefas, a produção de alimento para os habitantes do planeta Terra.

ALMEIDA (2000) completa que esse novo paradigma agronômico de realizar de maneira séria uma produção agrícola com equilíbrios e balanços energéticos que até então foram negligenciados é a arma para o sustento da população ainda crescente em níveis mundiais. Procurando conservar e aumentar o potencial natural, melhorando os rendimentos e a qualidade destes produtos de forma aceitável sem agressões ao meio para a subsistência da população futura.

E para que isso seja totalmente seguido é necessária a continuidade de analises e pesquisas em níveis globais com consistência política no intuito de incluir o maior número de pessoas para combater as grandes desigualdades sociais.

E dando continuidade, seguiremos com a Ciência Cartográfica que realiza a representação dos fenômenos terrestres por operações matemáticas, artísticas e técnicas. Esta ciência expressa estes fenômenos de forma gráfica com uma estética, simplicidade, clareza e harmonia resultando em um verdadeiro ideal artístico de beleza.

\subsection{CARTOGRAFIA}

A etimologia da palavra "Cartografia" (do grego Chartis = Mapa, e graphein = escrever; ato de representar por caracteres ou sinais gráficos) destaca uma grande relação com a Geografia. Pois, os mapas são resultantes da apreensão do espaço geográfico como se fosse um espelho que refletisse uma parte do conjunto complexo de equilíbrios móveis, regulados por causas múltiplas, interdependentes e interativas baseados na Geografia.

Desde os primórdios, o mapa era o principal instrumento utilizado pelos povos para sua orientação e informação no espaço geográfico. Ele era o principal veículo de comunicação entre os homens. Pois, assim se podiam obter subsídios para a representação adequada da "realidade".

Desta forma, são exaustivas as inúmeras definições que encontramos para a Cartografia desde o surgimento dos primeiros "mapas" nos tempos mais remotos registrados Rodríguez, A. C. M. 
pelo homem. Porém, achamos necessária uma revisão histórica de alguns autores conceituados.

A Cartografia, segundo publicação da Organização das Nações Unidas (1949), é definida como a ciência que trata do estabelecimento de mapas de todos os tipos. Ela engloba todas as fases de trabalhos desde os primeiros levantamentos até a impressão final dos mapas.

Em 1966, a Associação Cartográfica Internacional apresentou como definição de base: "Conjunto de estudos e de operações científicas, artísticas e técnicas que intervêm a partir de resultados de observações diretas ou da exploração de uma documentação, tendo em vista a elaboração de mapas, plantas e outras formas e expressão, bem como em suas utilizações".

Com SALICHTCHEV (1977) têm-se duas definições. A de 1973 afirma que a "cartografia é a ciência da apresentação e do estudo da distribuição espacial dos fenômenos naturais e sociais, suas relações e suas transformações ao longo do tempo, por meio de representações - modelos icônicos - que reproduzem este ou aquele aspecto da realidade de forma gráfica e integrada". O autor mostra uma evidente aproximação com as duas áreas da geografia, a física e a humana.

$\mathrm{Na}$ definição de 1977, o mesmo estudioso coloca que, a "Cartografia Científica Contemporânea" teria que ter como finalidade principal a representação e investigação dos sistemas espaciais (seu objeto) por meio da modelagem cartográfica (seu método). Este objetivo não poderá ser atingido sem o conhecimento do sistema que está sendo modelado e sem o suporte das ciências que o estudam. Aqui o autor assinala incisivamente que para a cartografia ser uma ciência tem que ter um objeto e um método, além de apontar a extrema necessidade de sermos conhecedores das ciências que cuidas do estudo do objeto de representação.

Em tempos mais atuais contamos com a definição proposta por TAYLOR (2003), onde a "Cartografia é a organização, apresentação, análise e comunicação da espacialidade georreferenciada sobre amplo leque de temas de interesse e uso para a sociedade num formato interativo, dinâmico, multimídia, multisensorial e multidisciplinar".

No mesmo ano, 2003, a Associação Cartográfica Internacional divulga em sua definição, dita "longa", que a Cartografia é a habilidade impar para a criação e manipulação de representações visuais ou virtuais do espaço geográfico - mapas - para permitir a exploração, análise, compreensão e comunicação da informação sobre esse espaço.

Existem denominações para a Cartografia com base nas artes plásticas em conjunto às metodologias sistemáticas cujo objetivo é alcançar representações em diversas formas Rodríguez, A. C. M. 
de expressão gráfica. Pois, assim a mesma se lança como ciência com a participação da estética de forma clara e harmônica na busca de um ideal artístico e belo.

Para Charles H. Deetz (MARINHA DO BRASIL, 1949) a Cartografia é a ciência da arte de expressar graficamente por meio de mapas e cartas o conhecimento adquirido sobre a superfície da Terra em suas mais variadas formas.

Nesta mesma obra ainda se defende que a Cartografia coordena as determinações dos astrônomos e matemáticos juntamente com os topógrafos e geodesistas na representação do quadro das características físicas da superfície terrestre. Onde, as mesmas podem sofrer modificações e transformações por conta das interferências dos homens e possibilitar um conhecimento exato e ordenado dos fenômenos terrestres.

$\mathrm{Na}$ verdade, a Cartografia está intimamente ligada à construção de mapas que empregam se adotarmos uma visão estruturalista, uma linguagem, a linguagem da representação gráfica para expressar aspectos, características e transformações evidenciadas e ocorridas ao longo do tempo e espaço.

Desde os tempos remotos a Cartografia já era utilizada como comunicação gráfica pela humanidade. A história documenta que os povos egípcios, babilônicos, chineses, indígenas, entre outros, buscavam de uma forma geral que os mapas o localizassem ou mesmo representassem alguma feição do ambiente em que viviam.

Durante os primórdios do surgimento da civilização dos gregos se deu a construção do pensamento geográfico sistematizado com a participação da linguagem Cartográfica. Foi através desta linguagem que se registrava as posições e os meios de deslocamentos que envolviam as necessidades de uma população advinda da barbárie primitiva, a qual não estava preocupada apenas em narrar simplesmente os fatos, acontecimentos e costumes.

SILVA (1943) destaca que naquele tempo se construía uma espécie de "morfologia do mundo", onde era narrado o que ocorria, o que era visto, o que era sentido, porém com uma característica local sem qualquer dedução ou sistematização de forma ou essência em registros e descrições.

Esse autor completa que, os gregos representavam em um mapa a extensão das terras que habitavam e que percorriam. Tratava-se de concepções de um verdadeiro cartógrafo na organização de um mapa.

Entre os mapas mais antigos que se teve como registros descobertos citam-se, o mapa, que é uma planta, talvez da cidade de Catal Höyük (Anatólia, Turquia) datado de 6.200 a.C. e o "Mapa de Bedolina". Este último é de uma aldeia neolítica gravado em 
rochedo na localidade de Capo di Ponte no Vale Canonica, onde escorre o rio Oglio, no norte da Itália, Região do Piemonte, datado de 2.500 a.C. (FIGURA 1).

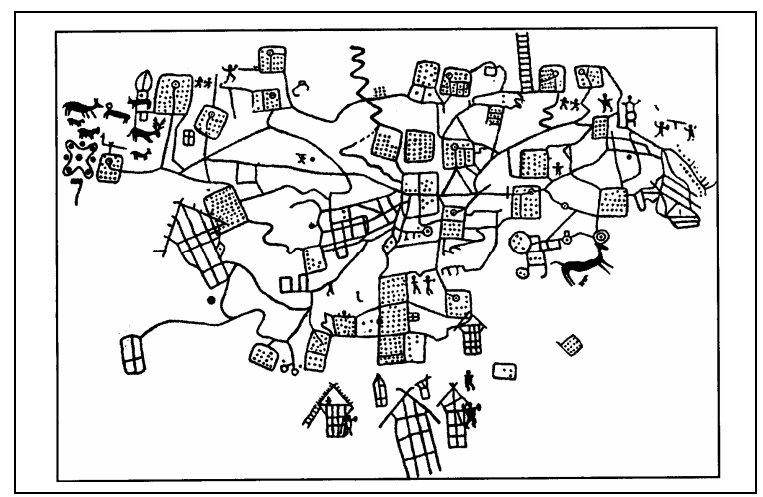

FIGURA 1 - Mapa de Bedolina no norte da Itália.

FONTE: OLIVEIRA (1993).

Outro mapa antigo conhecido está modelado em um tablete de argila cozida $(7 \times 8$ cm) e foi descoberto nas escavações das ruínas da cidade de Ga-Sur (2.400 a.C.) localizado a cerca de $300 \mathrm{~km}$ ao norte de Babilônia (Iraque). O qual representa um vale fluvial, com os rios Tigre - que se divide em três afluentes - e o Eufrates que desembocam no Golfo Pérsico, ladeados à Leste por elevações montanhosas - os Montes Zagros. Descrevia graficamente o ambiente vivido pelos sumérios para localização e planificação de operações militares. Tem 4.500 anos de idade, e conserva-se no Museu Semítico da Universidade de Harvard (USA) (SILVA, 1999). (FIGURA 2).

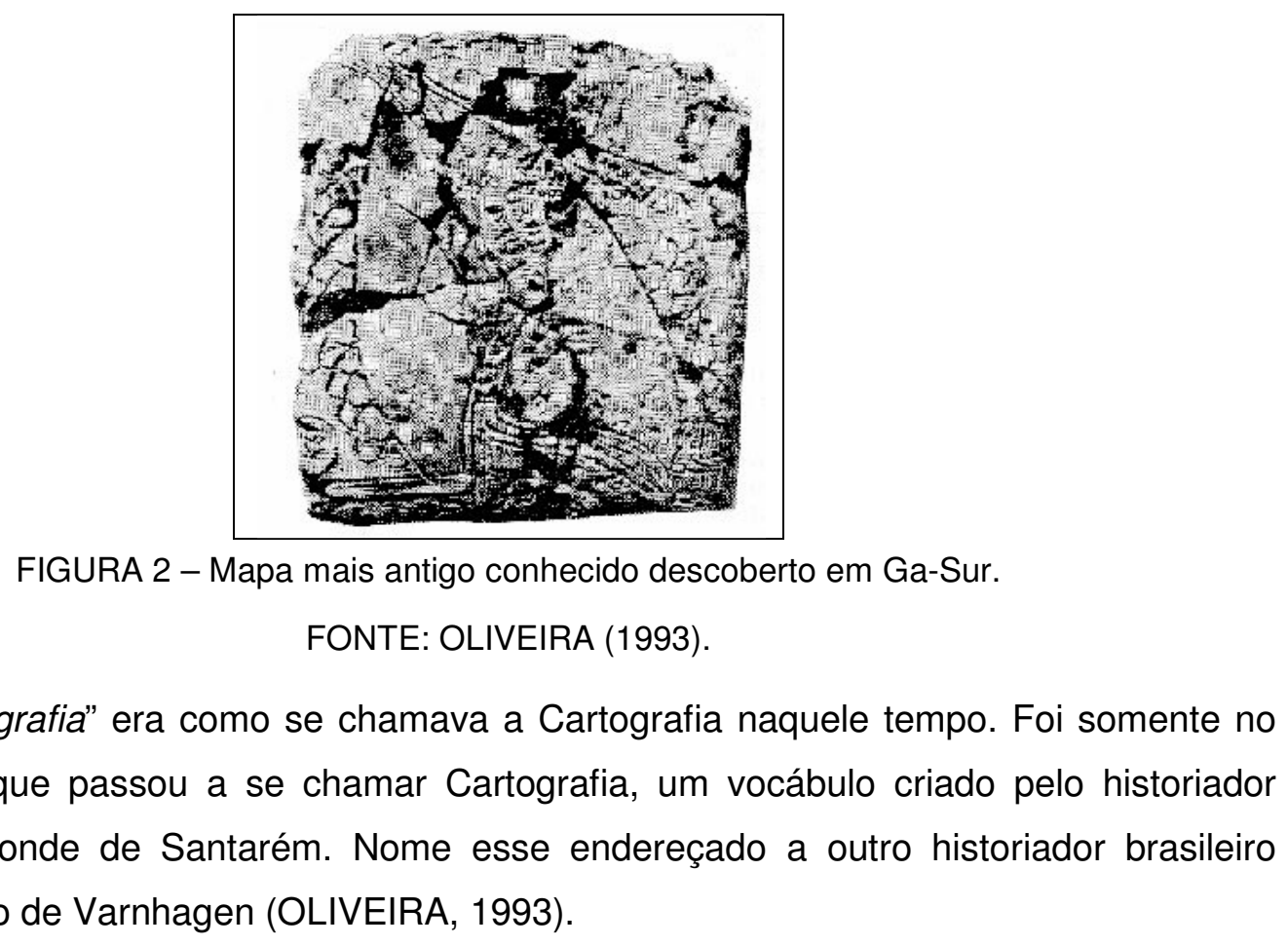


Esse mesmo autor apresenta um esquema gráfico realizado por índios brasileiros da região do rio Xingu, mostrando alguns dos afluentes e inúmeras corredeiras de nomes indígenas adquirido por Karl Von Den Steinen.

Outros mapas bem diferentes, feitos como estruturas, são as cartas marinhas confeccionadas pelos primitivos indígenas da Oceania. As ilhas do Pacífico eram assinaladas por conchas de praia dispostas sobre uma rede de fibras de palmeiras de coqueiro. A carta que se apresenta, mostrava claramente o movimento das frentes de onda no arquipélago das Ilhas Marshall (FIGURA 3).

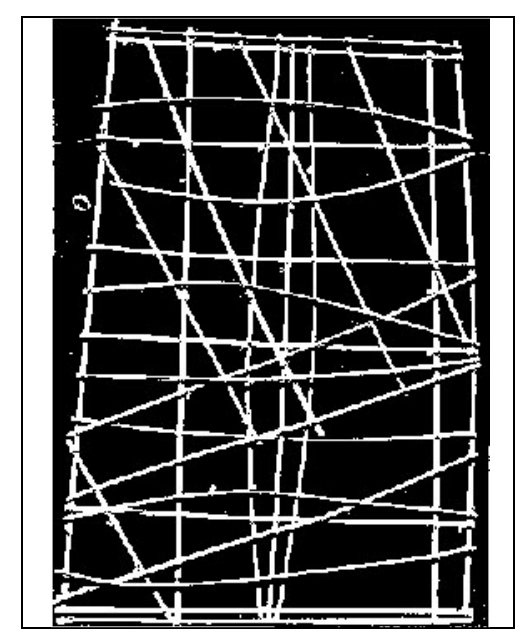

FIGURA 3 - Mapa esquemático das Ilhas de Marshall.

FONTE: OLIVEIRA (1993)

A representação do mar aberto, das correntes e das ilhas era de extrema importância para aqueles habitantes da Micronésia, pois desta forma era fácil a busca de alimentos para o sustento e para própria sobrevivência. Mas, isso só se tornou claro e compreensível depois de longos anos de estudo dentro do campo da navegação.

As coisas do cotidiano egípcio eram as de maior destaque nos mapas, pois assim o povo podia identificar áreas de interesse pelos registros do vale e do delta do Rio Nilo ambos elaborados entre 1.333 e 1.300 a.C. Uma espécie de cadastro tornava naquela época a cobrança de impostos sobre a terra mais incisiva, como também facilitava o levantamento da produção.

Desta forma, os mapas não eram considerados apenas como traços gráficos em suportes dos mais variados, mas também como estruturas montadas com vários materiais. A Cartografia era baseada em resultados de observações diretas ou de análise de documentação, visando à elaboração e preparação de cartas, projetos e outras formas de expressão. 
$\mathrm{Na}$ Idade Média, os cartógrafos não representavam o mundo em sua figura homóloga, pois eles exprimiam o seu próprio pensamento pelas idéias simbólicas com profundo significado artístico, fiéis às posturas das Escrituras Sagradas.

Nesta época, com a queda do império Romano e a difusão do Cristianismo houve uma sensível regressão no conhecimento científico de modo geral. Com isso, todas as interpretações começaram a ser baseadas em estudos bíblicos, onde do contrário provocavam perseguições e retaliações.

Assim, a adoção de conhecimentos geográficos e cartográficos bíblicos era claramente evidente, onde se destacava um mapa circular com características teológicas e sem apreço geográfico, o qual era bem difundido na época denominado "Orbis Terrarum".

O "Orbis Terrarum" era uma representação da Terra como um disco e ao seu redor existia a água dos oceanos. Esta era a forma como os geógrafos jônicos consideravam a Terra. Por sua vez, os romanos não consideravam uma Cartografia matemática, eram traçados topológicos e seus principais interesses eram para fins militares e administrativos.

Esse pensamento era totalmente divergente da Filosofia Grega que pregava um sistema cartográfico mais avançado, onde a Terra tinha uma forma esférica com os pólos, o equador e os trópicos. Na verdade, foram os gregos que introduziram o sistema de coordenadas, tendo elaborado também os primeiros cálculos para a circunferência do planeta (PEREIRA, 2000).

No século XV, a obra de Ptolomeu "Geographia" (1405) que se encontrava em Árabe foi traduzida para o Latim por esforços dos romanos, época a qual se promovem as grandes viagens marítimas e consequentemente a descoberta de novas partes do mundo.

Nos mapas de Ptolomeu não se encontrava uma estrutura geométrica para o entendimento do mundo inteiro. Pois, sua grade, dita ptolemaica, descrevia uma unidade matemática imediata, onde os locais mais distantes podiam ser precisamente fixados uns com relação aos outros por coordenadas imutáveis. Tal que a sua distância proporcional e os seus relacionamentos direcionais eram evidentes.

Durante o século citado, o sistema feudal começa a ser esquecido por conta de seu confuso sistema de direitos e obrigações legais em contrapartida a um renascimento da Cartografia de exatidão geográfica.

Inicia-se assim, uma nova era para a Cartografia por volta de 1500. E a valorização da representação espacial se torna algo determinante principalmente nas áreas econômicas e políticas. Os detalhes das navegações e da propriedade da terra começam a ser mais precisos e mais bem representados. 
Apesar da literatura sobre cartografia ressaltar a primazia dos ocidentais nos feitos cartográficos, para MANTERO (1953) um povo que sempre esteve à frente dos europeus foram os chineses. Eles foram pioneiros na confecção de mapas de todo seu território, logo depois da invenção do papel (100 a.d.C.). Os chineses eram considerados para a Cartografia um povo de grande progresso e independência do ocidente e por isso pareciam pertencer a outro planeta.

O mais antigo mapa chinês conhecido datava de 1137 (d.C.), sendo uma placa de pedra caracterizando a grande muralha que cruzava o Rio Amarelo.

Com o renascimento da Cartografia, a elaboração de mapas se torna uma atividade de interesse crescente devido principalmente aos desbravamentos de novas terras no além mar, surgindo assim mapas mais confiáveis e precisos. Destacam-se também o acúmulo de descrições próprias da Geografia associadas à Cartografia que eram de outras ciências como Climatologia, Geologia, Geomorfologia, Botânica, Zoologia, Biologia, Antropologia entre outras.

Em pleno renascimento Cartográfico, o sistema ptolemaico proporcionou aos florentinos um instrumento cartográfico perfeito com propriedades de expansão para o acúmulo, a verificação e a correção de conhecimentos geográficos. Dando à Geografia subsídios com princípios estéticos e harmônicos geométricos próprios da expressão artística dos florentinos.

O século XV, época das grandes navegações e descobertas portuguesas e espanholas apresentavam mapas que comunicavam ao Velho Mundo o inventário das novas terras. Destacamos a elaboração do mapa do Brasil pelo cartógrafo português Lopo Homem-Reineis, intitulado Terra Brasilis datado de 1519, no qual descreve não apenas o formato do território, os acidentes geográficos, a hidrografia e os recortes do litoral (desde o Maranhão até o Rio da Prata), mas incluiu também iluminuras dos habitantes nativos, de suas atividades (principalmente a exploração de pau-brasil), de espécimes da fauna e flora nativas (TERRA BRASILIS, 2008).

No século XVI, os Holandeses, povo bastante navegador e colonizador, apresentavam bons conhecimentos de Cartografia devido aos inúmeros navegantes, mercadores, artistas, estudiosos de várias nações que passavam por seu país. Esse período foi considerado como a época ouro da Cartografia. Deu-se, então o surgimento do pai dessa Cartografia o Gerard Kremer (1512-1594) mais conhecido como Gerardo MERCATOR.

O "Teatrum Orbis Terrarum" criado pelo também cartógrafo holandês Abraham Ortélio em 1570 foi o primeiro atlas moderno do mundo (FIGURA 4). 


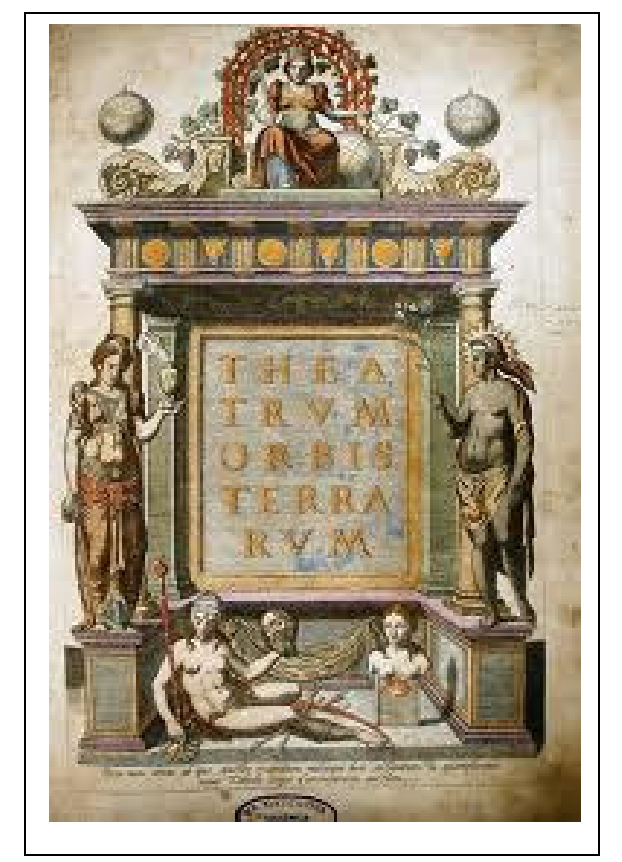

FIGURA 4 - O "Teatrum Orbis Terrarum".

FONTE: http://commons.wikimedia.org/wiki (2010).

E quase já na metade do século $\mathrm{XVI}$, os franceses eram os únicos influenciados por traços medievais, onde foram se distanciando por Nicolas Sanson ABDEVILLE (1600-1667). Segundo MANTERO (1953), muitos historiadores dizem que esta influência era pautada pela marca registrada dos cartógrafos holandeses originada dos flamencos. Os mapas produzidos tinham embasamento científico com pouca apelação decorativa e sem muitas notas descritivas, assim como esclarecimentos geográficos.

Os ingleses, por sua vez se assemelhavam aos holandeses em seu estilo e marca se atenuando ao extremo exagero de detalhes, sem falar na imensa confusão por conta da falta de proporcionalidade em seus mapas. Seu principal fundador foi o inglês Christopher SAXTON (1542-1608).

Também nesta época, os cartógrafos italianos se tornavam bastantes fecundos na importância da figuração da Cartografia como uma arte. Dá-se o período do mais alto Renascimento italiano, onde se destaca como o mais célebre P. Vincenzo CORONELLI (1650-1718) fazedor de globos terrestres (PEREIRA, 2000).

E já no século XVII, a concepção européia sobre a Terra, assim como sua Cartografia começam a ter outros caminhos que provocam profundas modificações por conta da esfericidade da Terra. Surge a chamada Teoria Heliocêntrica devido unicamente aos resultados das observações de Copérnico, seguidas pelas de Galileu e Keppler sobre a Terra, onde a qual não era mais considerada como o centro do Universo e sim o Sol. 
Essa nova teoria juntamente com as descrições obtidas pelas grandes navegações proporciona profundas mudanças nas concepções filosóficas do povo daquela época, e atreladas às questões econômicas vão aos poucos iniciando o desenvolvimento das ciências de forma geral como da Geografia, Cartografia, Astronomia e Engenharia.

A Cartografia em seu processo de sistematização se torna mais evidente, assim como os demais segmentos da cultura da humanidade. $O$ apelo científico é mais forte neste período pelo uso de longitudes determinado pela Academia Francesa e pautada em observações simultâneas em vários lugares do mundo, dos satélites de Júpiter. O que proporcionou a construção de um mapamundi elaborado por Jean Dominique Cassini (1682) resultando num dos mais famosos mapas fundamentais da história.

E um fato importante observado neste mapamundi era que a França se apresentava muito menor do que na representação de Sanson. Havendo sérios comentários entre Luís XIV e Cassini sobre essa medição, onde diziam que tinham tirado da França mais do que o Rei havia dado em todas suas guerras de conquistas (MANTERO, 1953).

No século XVIII, se presencia um grande marco histórico na Cartografia, a criação do primeiro mapa da America do Sul, com uma escala aproximada de 1:5.000.000 elaborado pelos autores De La Cruz, Caño e Olmedilla.

A Cartografia entra em uma nova era na produção de mapas com o objetivo de desempenhar papéis administrativos, políticos, militares e de engenharia. Os europeus são os pioneiros neste investimento pelos seus levantamentos topográficos designados dos serviços geográficos e dos exércitos.

Assim, a progressiva especialização e diversificação das realizações da Cartografia Científica operada desde os séculos XVII e XVIII, e cristalizada no século XIX, em atendimento às crescentes necessidades práticas como a de grande precisão culminaram com a elaboração de mapas de diversas categorias cada vez mais específicos, os quais hoje são denominados mapas Temáticos.

Mas, segundo BERTIN (1971) antes do surgimento dos mapas Temáticos, os Topográficos eram os mais usados devido ao detalhamento e precisão que apresentavam nos levantamentos topográficos para uso militar realizado por muitos países. No entanto, os Topográficos e Temáticos eram produtos intrinsecamente relacionados em busca de uma constante representação cartográfica na sistematização do conhecimento geográfico.

Na França, uma primeira série sistemática de mapas Topográficos foi elaborada pelo astrônomo francês Cesar-François Cassini de Thury (1714-1784). Esse grande avanço nestes mapas foi datado do século XVIII juntamente com a instituição das academias científicas, um marco grandioso da Ciência Cartográfica Moderna (MARTINELLI, 2007). 
No Topográfico se descrevia informações detalhadas do terreno permitindo a determinação da posição planimétrica e altimétrica de qualquer ponto em uma região. Para MENEGUETTE (1987) o objetivo principal era retratar e identificar as feições da superfície terrestre tão fielmente quanto possível, dentro das limitações impostas pelas escalas.

Já para OLIVEIRA (1993) os Topográficos eram elaborados mediante um levantamento original ou compilação de outras topográficas existentes, e que inclui os acidentes naturais e artificiais permitindo a determinação de direções, distâncias e altitudes, como no caso de cartas de acidentes planimétricos e altimétricos que são geometricamente bem representados.

Entretanto, não bastavam apenas os mapas Topográficos, pois com o desenvolvimento de vários ramos científicos e suas respectivas especializações era necessária a construção de mapas mais específicos, o mapa Temático, como já apresentado acima. E por volta do final do século XVIII e inicio do século XIX, com gestação iniciada no século XVII, surgem os mapas Temáticos, onde os primeiros a serem confeccionados foram os geológicos, os meteorológicos, os oceanógrafos, os biológicos entre outros, iniciando uma nova fase para a Cartografia.

E, por conseguinte, ocorre a expansão da civilização ocidental em todo o mundo levando a uma unificação em relação aos conhecimentos das áreas de política, religião, ciência, arte, filosofia e principalmente da economia.

A Cartografia torna-se expressão da Geografia (ARCHELA, 1999), ou seja, fazer Geografia era fazer mapas (LACOSTE, 1988). A consolidação dos conhecimentos cartográficos foi um pressuposto marcante para a sistematização da Geografia (início do século XIX) (MORAES, 1983).

Por conta disso, várias disciplinas (geologia, botânica, zoologia, climatologia, demografia, entre outras) vêem a necessidade de cartografar seus diversos tipos de fenômenos presentes no mundo real, surgem às cartas temáticas. Os mapas não são mais instrumentos de trabalho apenas do geógrafo, mas de todas as ciências por revelarem as diferentes visões de mundo.

Desta forma, para falarmos mais especificamente das cartas ou mapas temáticos que representam a localização do espaço e também indicam distribuições, padrões espaciais de um fenômeno, utilizaremos a Cartografia Temática. Ela tem a função de registrar, tratar dados e comunicá-los, com o fim de revelar o conteúdo da informação (MARTINELLI, 1991). 


\subsubsection{CARTOGRAFIA TEMÁTICA}

O surgimento da Cartografia Temática se deu no fim do século XVIII e inicio do século XIX, devido à busca de se representar em mapas variados temas de interesse para os diferentes ramos de estudo que despontaram com a divisão do trabalho científico. $\mathrm{Na}$ verdade se desenvolveu outro tipo de cartografia, onde as visões topográficas não foram extintas, apenas complementadas pelas sobreposições de temas específicos.

Segundo ROBINSON (1982) a criação de novos temas a serem tratados pela Cartografia se deveu à preocupação com o mapeamento da utilização da terra, ou seja, o mapa topográfico ia sendo cada vez mais enriquecido com o acréscimo de assuntos temáticos.

Nessa nova Cartografia se observa a passagem da representação das propriedades apenas "vistas" de cunho Topográfico para as propriedades "conhecidas" dos objetos, fatos ou fenômenos de cunho Temático. Ou seja, o código analógico é substituído por outro mais abstrato com o qual se representam, agora, categorias mentalmente e não mais, apenas visualmente organizadas.

Os mapas temáticos ofereciam então, informações pertinentes a diversos fenômenos ou temas específicos de determinada área, cidade, estado ou país. Eles representavam conjuntos espaciais resultantes da classificação dos fenômenos que integram o objeto de estudo. MARTINELLI (2007) coloca que o mapa temático é um meio de registro, pesquisa e de comunicação visual dos resultados obtidos em estudos especializados, não se trata unicamente de um mapa de ilustração.

Para BERTIN (1978) o mapa Topográfico continha o propósito de multiplicar a precisão das localizações (X, Y) para um número constante de fenômenos (Z). No mapa Temático se propôs uma abordagem expressa na forma estática ou dinâmica do espaço geográfico constante, multiplicando o número de fenômenos $(Z)$ para uma mesma localização $(\mathrm{X}, \mathrm{Y})$.

SANCHEZ (1981) defende que entre os mapas Temáticos e Topográficos (também chamados de base) não existem muitas diferenças já que dada às circunstâncias um mesmo mapa pode ser considerado um ou outro, conforme o modo de encarar seu conteúdo.

Mas, para MARTINELLI (1986) os mapas Temáticos possuem uma estrutura ou forma de distribuição dos fatos e fenômenos da realidade ligados à escolha de um determinado tema. Ou seja, os Temáticos se diferenciam por ter escalas pequenas com o intuito de tentar compreender o global e têm aplicação que se condizem ao nível regional de estudo. 
LACOSTE (1988) comenta ainda sobre a pluralidade dos mapas temáticos para um mesmo território evidenciando a abordagem geográfica, para a qual não só conjugam as interseções dos diferentes conjuntos espaciais que cada tema desenha, mas também se articulam os diversos níveis escalares de representação condizente com a ordem de grandeza da manifestação dos fenômenos considerados naqueles temas.

Para o mesmo autor, o mapa temático reporta certo número de conjuntos espaciais resultantes da classificação dos fenômenos que integram o objeto de estudo de determinado ramo específico, fruto da divisão do trabalho científico.

Em tempos recentes, com o surgimento da era da informática, a ciência dos mapas tem como seu conceito central o da visualização cartográfica. Segundo TAYLOR, (1994), ela tem uma forma de amalgamar os entendimentos da cartografia associados à cognição e análise, à comunicação e às tecnologias computacionais. Na verdade, essa visualização é o elo para a aplicação da Cartografia computadorizada que viabiliza os procedimentos de análise e comunicação junto às representações feitas por mapas.

As tecnologias computacionais ainda oferecem a possibilidade de se elaborar uma cartografia dinâmica com grande potencial na manipulação interativa das informações espaciais. Assim, a inclusão automatizada da Cartografia se deu com o aparecimento dos computadores em 1946. E as primeiras aplicações foram empreendidas para cálculos matemáticos, astronômicos e geodésicos para a elaboração das projeções e tempo mais tarde no tratamento dos dados estatísticos (MARTINELLI, 2007).

Para MARTINELLI (2007) a construção de um mapa temático está literalmente baseada em considerações metodológicas de sua Cartografia específica elaborada no início por procedimentos analógicos sistematizados. Com os avanços científicos e tecnológicos do século XX o preparo de softwares para a Cartografia Temática proporcionou soluções ágeis e sofisticadas, não se desvinculando de uma boa e acurada avaliação crítica embasada na metodologia científica.

Podemos exemplificar os mapas Temáticos como: os de densidade demográfica, de temperatura, de fusos horários, de vegetação natural, de utilização da terra e de cobertura do solo, o geoidal do Brasil, entre outros.

Para a construção destes mapas era preciso atentar para uma representação gráfica inserida na comunicação visual e transcrita graficamente por um sistema de sinais. Porém, os sinais têm um conceito muito genérico e quando consideramos a Cartografia como uma linguagem esses sinais passam a ser chamados de "signos".

Segundo SALICHTCHEV (1988), as representações cartográficas podem ser expressas por imagens, símbolos de forma gráfica e generalizada, retratando a distribuição Rodríguez, A. C. M. 
dos fenômenos naturais e culturais com suas relações, e respectivas mudanças no tempo e no espaço geográfico.

Para a Geografia sempre foi primordial a representação de fatos e fenômenos através dos mapas, pois estes sempre foram sinônimos desta ciência. Os mapas são a representações simbólicas da Geografia. Porém, a Cartografia como a ciência dos mapas tinha a tarefa precípua de compô-los (MARTINELLI, 2009).

A representação cartográfica dos fenômenos é assinalada como uma operação básica para o registro, análise e comunicação do conhecimento geográfico. Logo, é comum afirmar que pensar o espaço geográfico significa necessariamente pensar na sua representação (NOAL, 2001).

Desta forma, a representação gráfica dos fenômenos será sempre uma imagem que transcreve relações entre elementos ou conjuntos. Onde, a mesma é definida prioritariamente e fundamentada pela importância do entendimento das bases da representação gráfica como sistema monossêmico de comunicação.

Para BERTIN (1971) a Cartografia de forma geral integra a representação gráfica, sendo ela uma linguagem dentre outras construída pelos homens para reter, compreender e comunicar observações indispensáveis à sobrevivência. Essa linguagem é bidimensional, atemporal e destinada à vista com total supremacia sobre as demais devido a proporcionar uma percepção praticamente instantânea, pelo fato de construir uma imagem.

Ao compor a imagem, a representação gráfica é apreendida pela vista em apenas poucos instantes de percepção. Essa imagem é totalmente diferente da figurativa ou abstrata como as da fotografia, pintura, grafismo, publicidade e propaganda com características polissêmicas, isto é, com significados múltiplos, a mesma deve tomar todo o cuidado de se apresentar em um sistema semiológico monossêmico. (MARTINELLI, 1999).

Para este autor, a representação gráfica se resume na linguagem da comunicação gráfico-visual de caráter monossêmico (significado único). Onde, a mesma se apresenta com fundamentos vinculados ao se dar mais atenção às relações entre os significados dos signos, do que entre os significados e os significantes dos signos, podendo distar, assim, de qualquer conversão constituída.

SIMIELLI (1986) descreve que para ter um total entendimento da linguagem cartográfica necessita-se conhecer, não só as regras da gramática dessa linguagem, bem como sua específica semiologia, no caso, a chamada de "Semiologia gráfica".

O signo é a idealização do próprio objeto e se constrói na relação entre o significante, o significado e o objeto referente (MARTINELLI, 2007). A linguagem da 
representação gráfica por suas regras utiliza os signos, os quais são estudados por uma ciência chamada de Semiologia, aja enunciada "Semiologia gráfica".

BERTIN (1977) diz que a representação gráfica não segue o processo de comunicação apoiado na teoria matemática da comunicação, mas sim num outro esquema por ele dito de comunicação monossêmica, onde existe um emissor (emite a mensagem) e um receptor (recebe esta mensagem), os quais se encontram do mesmo lado do processo comunicativo, tendo à frente a tarefa de transcrever relações de diversidade, ordem e proporcionalidade entre objetos (FIGURA 5).

\section{ATOR $\longleftrightarrow(\neq, \mathrm{O}, \mathrm{Q})$}

FIGURA 5 - Esquema da comunicação monossêmica.

FONTE: BERTIN (1988).

Desta forma, a tarefa essencial da representação gráfica é transcrever as três relações fundamentais destacáveis: de diversidade [₹], de ordem [0] e de proporcionalidade [Q]. As quais podem ser estabelecidas entre objetos por relações visuais de mesma natureza (FIGURA 6).

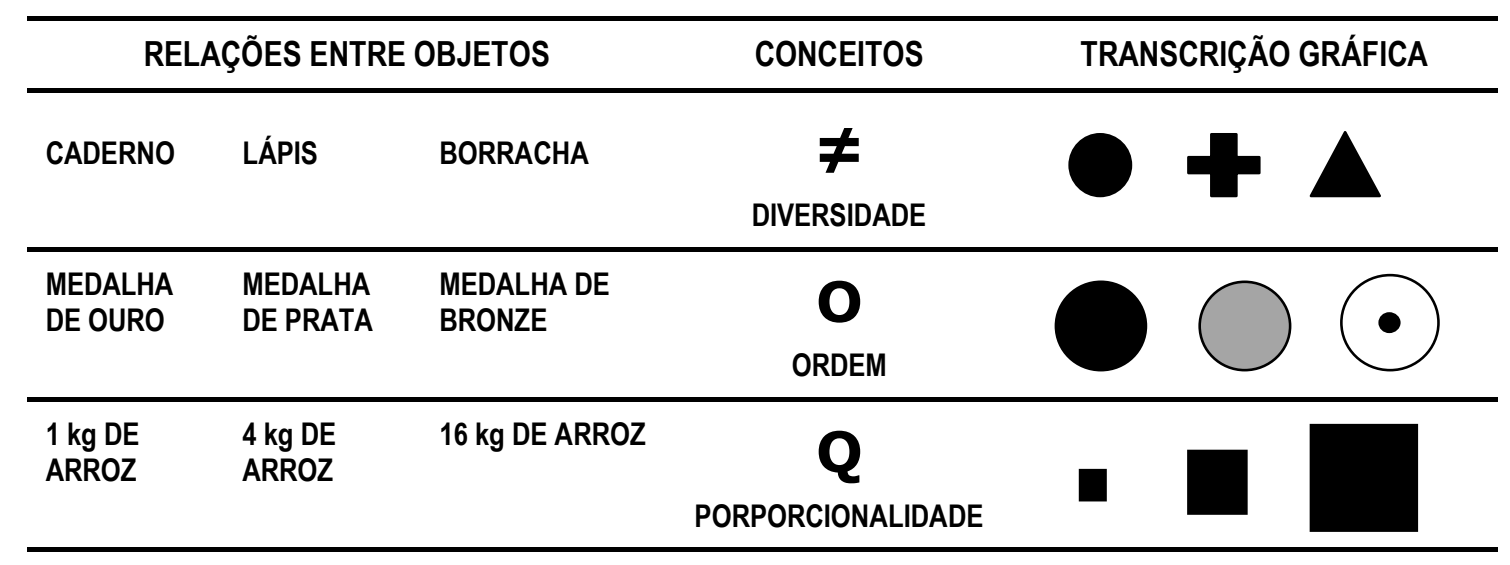

FIGURA 6 - Transcrição gráfica.

FONTE: MARTINELLI (2007), pg. 15.

Na comunicação da linguagem monossêmica existem o redator gráfico e o usuário que participam conjuntamente da ação. Diferindo da polissêmica que existe:

\section{(EMISSOR $\leftrightarrow$ CÓDIGO $\leftrightarrow$ RECEPTOR).}

Segundo BERTIN (1971 e 1978) a representação gráfica como mapas mobiliza as duas dimensões do plano (X-horizontal e Y-vertical) de localização e mais a variação visual (Z-perpendicular ao plano) de cada elemento bidimensional deste plano, a qual determina o conteúdo exato desta localização. 
De acordo com os autores, dentro da variação visual acima apontada, existem seis modulações visuais: tamanho, valor, cor, forma, orientação e granulação, as quais são assumidas por cada elemento do plano constituindo-se nas variáveis visuais.

Para BERTIN (1978) as variáveis visuais são dispostas em dois grupos: as que constroem a imagem e as que apenas separam os elementos da imagem. Podemos observar na FIGURA 7 a apreensão destas variáveis visuais.

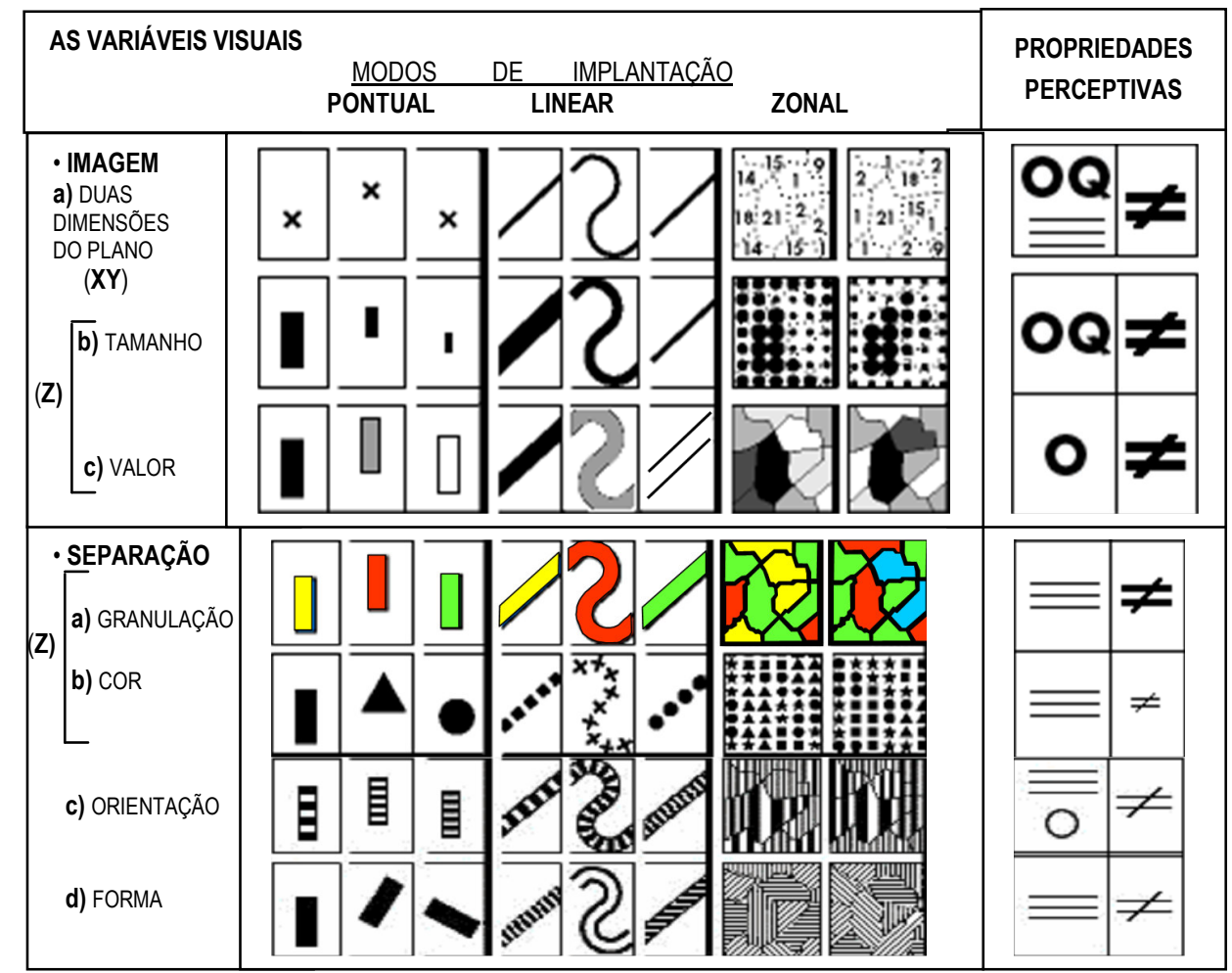

FIGURA 7 - Variáveis visuais.

FONTE: BERTIN (1978).

As variáveis da imagem como: as duas dimensões do plano, o tamanho e o valor são as que verdadeiramente constroem a imagem. Já as de separação como: a granulação, a cor, a orientação e a forma figuram apenas como elementos da imagem por não revelarem a figura que seu conjunto constrói (MARTINELLI, 2007).

O autor coloca que os mapas temáticos podem ser construídos levando-se em conta vários métodos; cada um mais apropriado às características e à forma de manifestação, a qual pode ser em forma de pontos, de linhas ou de áreas dos fenômenos considerados em cada tema, seja na abordagem qualitativa [₹], ordenada [0] ou quantitativa [Q].

É ainda importante frisar que os fenômenos observados na realidade geográfica podem ser apresentados no mapa mediante um raciocínio analítico ou de síntese. 
No nível de raciocínio podemos ter representações de análise e representações de síntese. Na análise são representados dos elementos constitutivos da realidade: lugares, caminhos ou áreas caracterizadas por atributos ou variáveis $\mathrm{Na}$ Síntese, após um tratamento específico dos atributos ou variáveis se elaboram mapas que fazem a fusão dos elementos construtivos em "tipos" que serão vistos como agrupamentos de lugares, caminhos ou áreas unitárias de análise caracterizadas por agrupamentos de atributos ou variáveis.

No aludido tratamento específico será necessário o uso de módulos de funções da estatística paramétrica para os dados numéricos, da estatística espacial ou de processamento de imagens. No caso das imagens e dos dados estarem embutidos na composição das radiâncias dos pixels das mesmas, pode-se, assim, obter resultados de forma ágil acerca das análises de componentes principais e de agrupamentos. Estes clássicos procedimentos da estatística fazem parte de novas tecnologias que impulsionou o surgimento de uma Cartografia computadorizada, a qual será contextualizada com mais ênfase a seguir.

$\mathrm{Na}$ elaboração dos mapas destacamos as duas dimensões $(\mathrm{X}, \mathrm{Y})$ do plano que representam a posição do lugar (referência). Respondem ao 'onde?'. Ela caracteriza a ordem geográfica única e não permutável (domínio da cartografia topográfica ou base cartográfica) (MARTINELLI, 2007).

Porém, os mapas também podem caracterizar os lugares, além de referir posições ou responder as questões "onde?'. Eles podem representar o tema quanto à apreciação dos fenômenos. Assim, podemos considerar as abordagens:

1. (₹) A Qualitativa que responde à questão "O QUÊ?", se caracterizando por relações de diversidade entre os conteúdos dos lugares, caminhos, ou áreas;

2. (O) A Ordenada que responde à questão "EM QUE ORDEM?", a qual se caracteriza pelas relações de ordem entre os conteúdos dos lugares, caminhos, ou áreas;

3. (Q) A Quantitativa que responde à questão "QUANTO?", se caracterizando por relações de proporcionalidade entre os conteúdos dos lugares, caminhos, ou áreas.

A Qualitativa vai apresentar como prioridade, não só a existência, como também o registro da diversidade entre os objetos, fatos ou fenômenos, diferenciando aspectos pertencentes à natureza, ao tipo entre outros baseados em orientações de classificação.

A Ordenada vem de encontro à relação de ordem observada entre os objetos, fatos, ou fenômenos que se definiriam na verdade por uma hierarquização. Já a Quantitativa é expressa por relações de proporcionalidade entre os objetos, fatos ou fenômenos, sendo transcritas por relações visuais de proporção. 
Todos os aspectos aqui descritos são também conferidos em métodos postulados desde o final do século XIX e trazidos aqui numa organização proposta por MARTINELLI (1991; 1999) (FIGURA 8). Desta forma, percebemos que fica muito mais fácil o entendimento destas várias modalidades da relação existente entre os objetos, fatos ou fenômenos da realidade e seu questionamento para a Cartografia Temática.

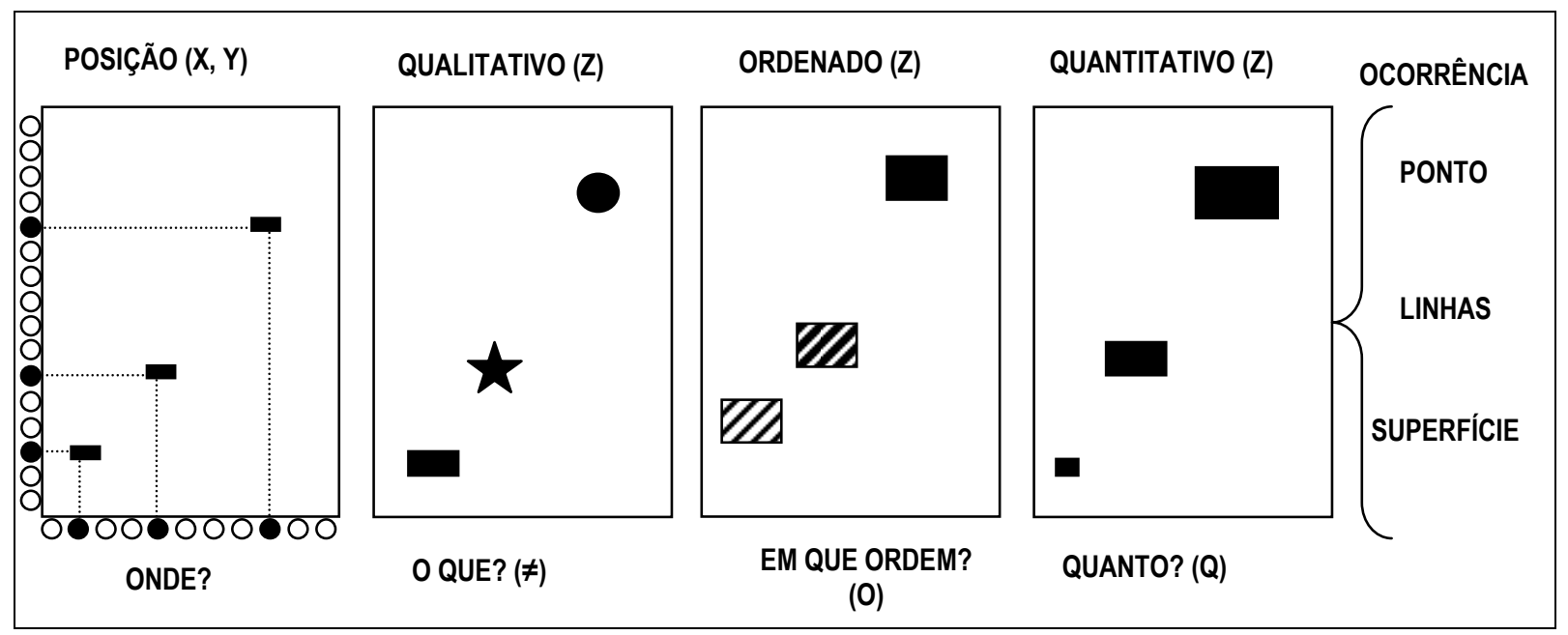

FIGURA 8 - Aspectos evidenciados na Cartografia temática.

FONTE: MARTINELLI (1991).

As variáveis visuais apresentadas têm propriedades perceptivas que devem ser consideradas na representação gráfica. Estas propriedades fundamentam as premissas básicas intrínsecas referentes a cada uma delas.

As propriedades que consideramos para a transcrição gráfica são as seguintes: a dissociativa, a associativa, a seletiva, a ordenada e a quantitativa. E só com o conhecimento e o entendimento claro destas somos capazes de utilizar adequadamente a gramática da representação gráfica para elaborar os mapas temáticos.

Na percepção dissociativa a visibilidade é variável e com o afastamento da vista os tamanhos diferentes tendem a sumir sucessivamente. Enquanto que na associativa essa visibilidade é constante permitindo uma confusão das categorias e com o afastamento da vista as mesmas não somem. Seria o caso de uma representação utilizando um número muito grande de signos em ponto com variação de forma (MARTINELLI, 2007).

Na percepção seletiva podemos isolar os elementos distintos mediante o emprego das variáveis visuais: cor, tamanho, valor, granulação e forma. A cor é a que discrimina melhor. Já na percepção ordenada as categorias são ordenadas espontaneamente pela exploração do valor, do tamanho e da cor quando colocadas em ordem visual, das claras até as escuras, seja entre as cores quentes como entre as frias. (MARTINELLI, 1991; 1999). 
E finalmente a percepção quantitativa é a que manifesta imediatamente a relação de proporção por conta apenas da percepção do tamanho. Ou seja, a relação de proporção visual é imediata.

A variável Cor é bastante seletiva e de indiscutível impacto nas ocorrências zonais. Essa variável é considerada como uma realidade sensorial sempre presente e se evidenciando por possuir grande poder de comunicação devido sua atuação sobre a emotividade humana.

$\mathrm{Na}$ figura abaixo mostramos a disposição das radiações do espectro eletromagnético, observe a faixa do Visível, a qual é sensível ao olho humano (FIGURA 9).

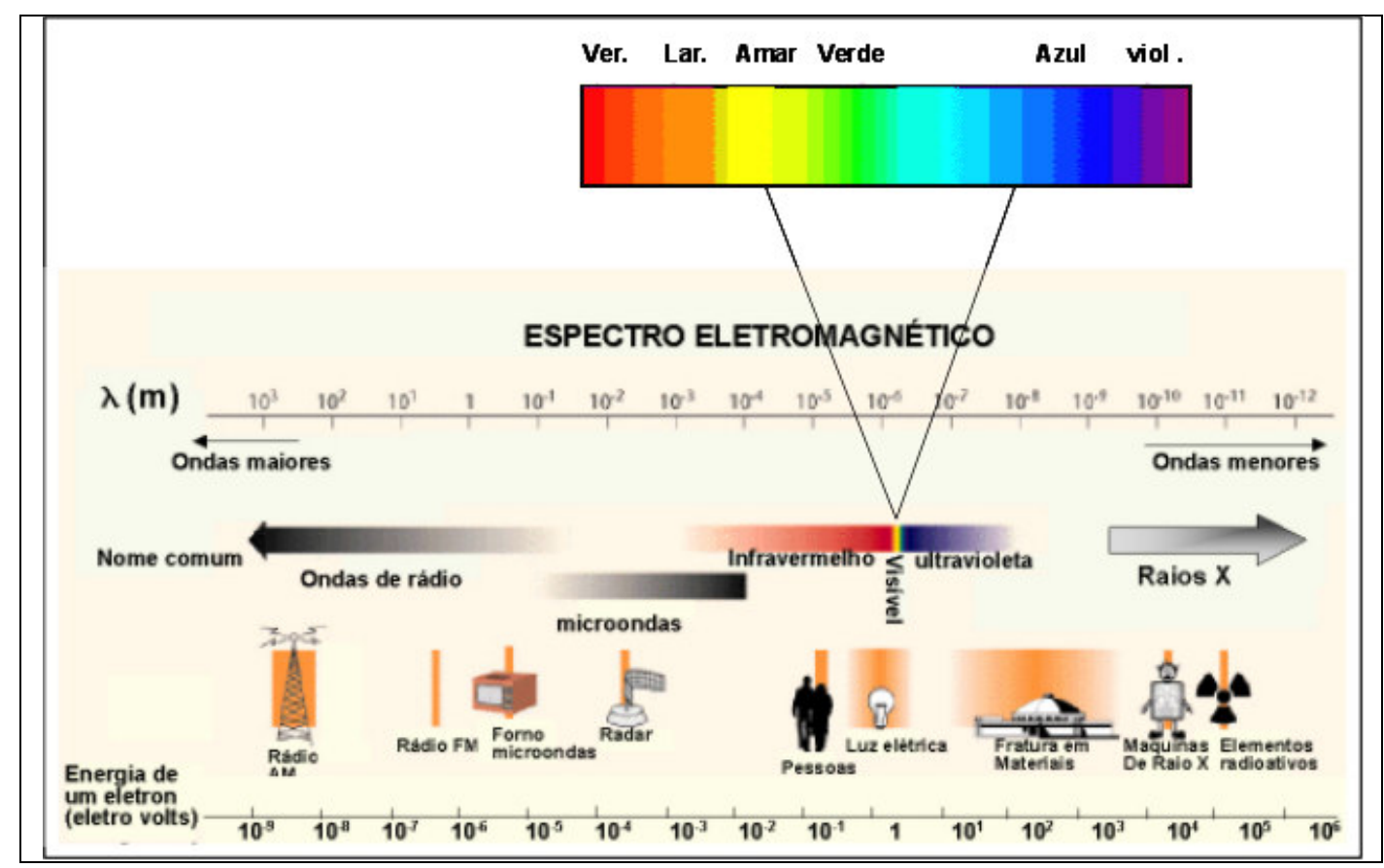

FIGURA 9 - Disposição das faixas do espectro eletromagnético.

FONTE: MOREIRA (2001), pg. 22.

A variável cor para a elaboração da representação gráfica é bem aceita no uso da terra e cobertura do solo, pois as mesmas discriminam facilmente, promovendo a identificação das ocorrências e manifestações em áreas dos fenômenos da natureza e da sociedade quando vistas em suas relações qualitativas. O método de representação que mobiliza esse procedimento é chamado de corocromático qualitativo.

$E$, quando somos sensibilizados por essa variável temos que ter em mente que existem três dimensões fundamentais que intervêm conjuntamente.

Segundo os teóricos da cor, estas dimensões são: o matiz, a saturação e o valor. A primeira é uma nuança cromática na sequência dos comprimentos de onda associada a 
uma radiação espectral bem definida (cor pura). A saturação é a variação assumida por um matiz desde o seu neutro absoluto (visto como cor cinza) até a cor pura espectral.

O valor é a quantidade de energia refletida indo de valores desde claros até escuros, como que se comparando a ir desde o branco até o preto, passando por inúmeros tons de cinza intermediários. Os quais devem estar escalonados em equidistâncias perceptivas compondo uma ordem visual.

De acordo com a sequência de cores espectrais da faixa do visível, na sucessão de seus comprimentos de onda, percebemos que existe uma dupla ordem visual bem clara e distinta. Na FIGURA 10 podemos notar essa organização sequencial de ordem visual em duas sucessões opostas de valores visuais no círculo das cores ou cromático.

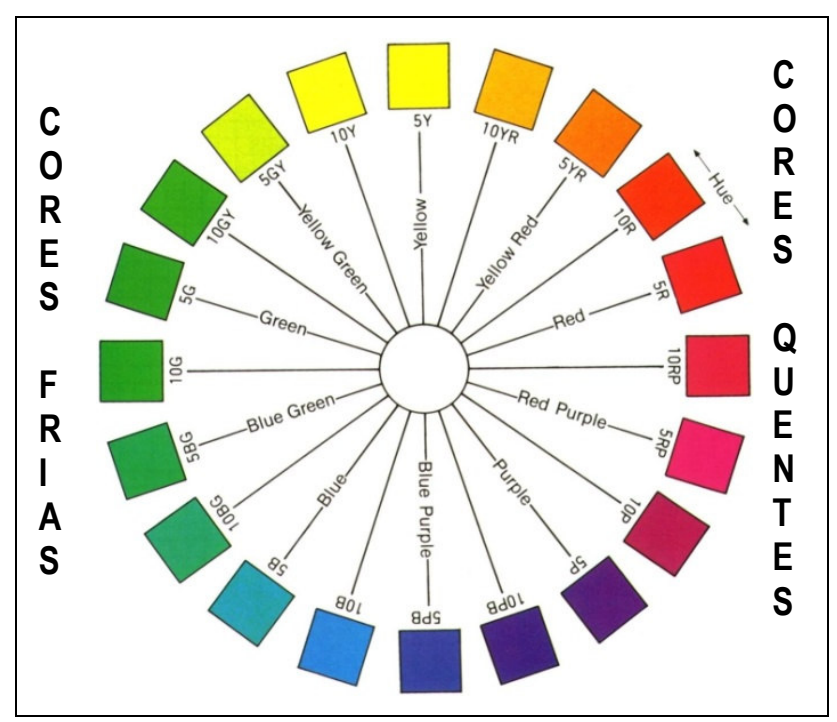

FIGURA 10 - Círculo cromático (Cores frias e quentes).

FONTE: http://pt.wikipedia.org/wiki/Sistema de cores de Munsell (2009).

No círculo vemos a sequência espectral de acordo com os comprimentos de onda (FIGURA 9). Na série do violeta, azul, verde, amarelo, laranja e vermelho, se consideram uma variação contínua de cores intermediárias, nuanças cromáticas diferenciadas pelos matizes. E misturando-se os extremos obtemos gradações de cores púrpuras, dando continuidade à série e fechando esta sequência em um círculo (MARTINELLI, 2007).

Também neste, se tomarmos como ponto de partida a cor amarela e irmos para o violeta, comporemos uma ordem visual crescente de cores, das mais claras para as mais escuras, entre as denominadas de cores frias.

De outro lado, ainda partindo da cor amarela e nos aproximando da cor vermelha a ordem visual crescente passa de cores claras para as escuras, entre as denominadas de cores quentes. 
A utilização prática e atraente das cores não se resume apenas em algo intencional. $\mathrm{Na}$ verdade, a idéia de combinações pode proporcionar a um evento ou fenômeno tensão por antagonismo num mesmo campo ou ao contrário passar a sensação de harmonia e quietude.

As cores opostas indicadas no círculo podem gerar um contraste, pois as cores serão extremamente opostas entre si. Já no caso de uma combinação harmônica necessitamos de um conjunto de cores vizinhas que possua uma parte básica comum a elas. Ou seja, uma escala monocromática, onde as cores sejam vizinhas entre si (MARTINELLI, 2007).

Esse autor chama atenção que com os conhecimentos acima adquiridos advindos do sistema monossêmico de signos ter-se-á a possibilidade de aplicá-lo em qualquer modo de representação de um fenômeno, tendo-se o cuidado de levar em conta todas as propriedades perceptivas das variáveis visuais. Pois, do contrário estaremos fadados a comunicar inverdades e falsidades.

Além, do julgamento dos fenômenos nas abordagens qualitativa [₹], ordenada [0] ou quantitativa [Q] existe a da apreciação do ponto de vista estático e dinâmico (MARTINELLI, 2007). E na apreciação dinâmica pode-se contar com as representações das transformações qualitativas de estados e das variações quantitativas no tempo, além das representações dos movimentos no espaço empregando certo tempo. As variações quantitativas podem ser apreciadas tanto em números absolutos como relativos. Nos movimentos mostram-se os fluxos destacando sucessivas posições no deslocamento de um móvel, a intensidade, a direção e o sentido dos fenômenos espaciais em movimento.

A representação dos fluxos é bastante significativa na abordagem do meio ambiente, pois o tempo e o espaço são partes integrantes da existência humana por suas características intrínsecas.

Para BERTIN (1978) a percepção do tempo é linear e sequencial ocupando apenas uma dimensão do plano em sua representação. Enquanto que a outra componente da informação é transcrita por uma evolução. Ela seria feita mediante um gráfico evolutivo.

MARTINELLI (2007) aponta que a associação da Cartografia frente às facilidades oferecidas pela informática e pela geomática faz despontar uma Cibercartografia. Essa nova Cartografia se fundamenta na valorização dos padrões espaciais que os atributos e as variáveis constroem visando o aspecto morfológico, em vez das constatações das distribuições geográficas.

TAYLOR (1994) comenta que essa Cibercartografia é capaz de mobilizar um número maior de novos meios e redes de comunicação e explorar formas emergentes de multimídia, Rodríguez, A. C. M. 
transformando a tradicional Cartografia, por vezes desacreditada, numa Cartografia dinâmica, multidimensional, multisensorial amplamente interativa e animada.

Mas, segundo MARTINELLI (2007) todo esse avanço tecnológico que proporcionam soluções ágeis e sofisticadas à Cartografia temática, não podem vir desacompanhado das fundamentações metodológicas vinculadas a uma boa e acurada avaliação crítica.

Nos anos 70, com o aumento significativo da produtividade e da rentabilidade da produção cartográfica foi necessário automatizar a Cartografia. Facilitando assim, não somente a elaboração e as atualizações dos mapas e cartas, mas também a difusão, suprindo as necessidades específicas dos usuários.

Desta forma, a Cartografia começou a ser vista como um conteúdo especializado atrelado a outras diversas ciências apoiada em seus pressupostos filosóficos da crescente e acelerada necessidade de representação da essência dos fenômenos ocorridos sobre a Terra, no seio das expectativas e necessidades da sociedade humana.

Com o advento de razões econômicas e militares torna-se necessária a grande produção de mapas precisos, em grande escala e automatizados por mão-de-obra estritamente especializada. Pois, a classificação qualitativa ou quantitativa empreendida por cada ciência sobre os diversos tipos de fenômenos era o caráter fundamental na configuração de um maior ou menor número de conjuntos espaciais resultando em um novo automatizado ramo da Cartografia.

A automatização da Cartografia provocou uma melhor elaboração dos mapas, originando novas preparações para as clássicas representações tridimensionais (blocosdiagrama) com um maior grau de complexidade, promovendo assim facilidade na análise e criação dos mapas a partir de dados estatísticos, reduzindo o grande volume de dados armazenados, além da rapidez e acessibilidade de recuperação de dados.

O desenvolvimento desta automatização, progresso das áreas temáticas e o sucesso de uso do mapa como recurso de estudo e ensino escolar além de pesquisa científica já definem a grande necessidade permanente de se repensar o objeto e os métodos da Cartografia para os dias atuais, como SALICHTCHEV já colocava em 1988 para aquela época.

E segundo esse mesmo autor, a comunicação cartográfica merece uma reflexão metodológica constante no sentido do surgimento de novas descobertas científicas sobre os métodos, hipóteses, previsões e recomendações desta ciência. Mas, a mesma possui sem sombra de dúvidas inúmeras metodologias a serem desbravadas principalmente com 0 advento da automatização. 
A necessidade crescente de representação do espaço geográfico e dos fenômenos, objetos de estudos das mais variadas ciências, possibilitaram o surgimento de avanços tecnológicos que permitiram uma constante análise e sistematização do conhecimento geográfico para o aprimoramento de pesquisas em Geografia, principalmente dentro do âmbito da questão social e da questão ambiental.

Para MARTINELLI (2007), o desenvolvimento das tecnologias computacionais trouxe para a Cartografia grandes inovações gráficas e fundamental aporte na manipulação de grande volume de dados. E possibilitou explorações de novas operações de multimídia proporcionando uma aplicação educacional interligando os lares às livrarias, escolas, empresas, instituições por rede de informação cartográfica.

A confecção dos mapas era executada com auxílio dos computadores operacionalizando todas as etapas de elaboração e construção dos elementos cartográficos. Onde, a manipulação e impressão dos mapas eram feitas de forma rápida e com grande número de dados, assim como, com uma enorme variabilidade de parâmetros específicos apoiados por análise matemática e estatística (JOLY, 1990).

A visualização e a multimídia como veículo de comunicação cartográfica deu início à interação entre o usuário e os mapas. Os quais levaram significativos avanços ao ensino da Cartografia e principalmente à comunicação em geral.

MARTINELLI (1986) completa que haverá profundas mudanças na disciplina da Cartografia por conta da automatização e manipulação interativa da informação espacial em tempo real fruto destes novos avanços tecnológicos.

A tecnologia da automatização da Cartografia deu início também aos SIG. Segundo SILVA (1999), sem nenhum exagero, os SIG, quando se dispõem a fazer mapas, estão inteiramente ligados e auxiliados pela Cartografia Moderna.

Para se ter uma idéia, os SIG surgiram na década de 60 por um grupo de pesquisadores canadenses ligados ao Governo com intuito de gerenciar informações de recursos naturais e ambientais, que poderiam ser dispostos não só em bancos de dados, como também em mapas.

BÄHR (1993) não acredita que seja possível existir um SIG sem que este esteja diretamente ligado a Ciência Cartográfica. Pois, a tecnologia deste foi processada da Cartografia com soluções matemáticas e gráficas para a representação de feições naturais, artificiais, além de área, linha e pontos (BRANDALIZE, 1993).

Quando diferenciamos um software de Cartografia para um SIG, o primeiro parâmetro observado é a capacidade de armazenar a topologia de um mapa e também de 
tratar diversas projeções cartográficas (CÂMARA, 1995). E LIBAULT (1967) completa que a Geografia conjuntamente com a Cartografia forma um todo indissolúvel.

Já quando essa Cartografia se alia ao SIG e também ao Sensoriamento Remoto (SR) atrelado ao uso dos satélites, tornam-se fontes indiscutíveis para o conhecimento do espaço geográfico constantemente modificado e transformado pela ação humana.

O emprego da Cartografia conjuntamente com o SIG e o SR possibilita a coleta, o armazenamento, a recuperação, a análise, a síntese e a apresentação das informações acerca dos lugares monitorados no tempo, e proporcionam simulações de eventos e situações complexas da realidade para o provimento de decisões deliberadas.

Assim, a análise de mudanças ambientais ocorridas em uma região também pode ser facilmente praticada quando aplicamos a Cartografia, o SIG e o SR, os quais possibilitam o estudo do espaço ao longo do tempo permitindo a aquisição, armazenamento e manipulação de informações de forma rápida e eficiente, proporcionando a tomada de decisões e dirimindo os impactos ambientais.

\subsubsection{CARTOGRAFIA DO USO E COBERTURA DA TERRA}

Entende-se pelo termo "Terra" o segmento da superfície do globo terrestre definido no espaço e reconhecido em função de características e propriedades compreendidas pelos atributos da biosfera, que sejam razoavelmente estáveis ou ciclicamente previsíveis, incluindo aquelas de atmosfera, solo, substrato geológico, hidrologia e resultado da atividade do homem (FAO, 1976).

Segundo SKOLONSKI (1999) no estudo da Terra é importante considerar, entre suas características, não apenas o solo, mas também outros atributos físicos como o relevo, vegetação, suprimento de água (clima) entre outros.

O "Uso e cobertura da terra" envolvem a forma pela qual o espaço geográfico é ocupado pelo homem, sendo este responsável pelas práticas de gestão do território e de usos sobre os ecossistemas e os recursos naturais existentes.

O termo "Uso da terra" considera as atividades exercidas pelo homem nesta, enquanto que o de "Cobertura da terra" refere-se ao seu revestimento (NOVO, 1989).

Em CLAWSON e STEWART (1965) o termo "Uso da terra" se refere à atividade do homem na terra, que se acha diretamente relacionada com a terra. E o seu revestimento descreve a vegetação e construções artificiais que recobrem a superfície da terra (BURLEY, 1961). 
Por outro lado, o termo "Uso do solo" diz respeito a uma combinação de uma modalidade de uso (atividade) e de uma forma de assentamento (edificação). Segundo DEÁK (1985) a principal finalidade deste, é regular e controlar por leis de zoneamento ou leis de uso do solo, as diversas atividades e assentamentos no espaço geográfico.

O autor completa que o "Uso do solo" de um espaço urbano é constantemente alterado e sujeito à obsolescência de seu capital fixo. O processo de obsolescência comanda o processo de uso do solo, logo comanda a substituição da técnica de produção, materializada no capital fixo de um processo de produção qualquer.

Estes autores comentam que as finalidades do estudo do uso da terra estão ligadas no planejamento e administração de uma região. E para ficar mais claro a diferença entre estes dois termos os exemplificaremos da seguinte maneira: as áreas florestais apresentam apenas um único tipo de cobertura, mas podem ter ou compreender diversas formas de uso como: lazer, exploração de madeira, reservas biológicas, etc.

O levantamento ou mapeamento do "Uso e cobertura da terra" favorece a compreensão dos padrões de organização do espaço geográfico possibilitando o seu conhecimento e planejamento.

Historicamente os estudos sobre o mapeamento do uso da terra se iniciaram em 1930 por Sir Dudley Stamp no levantamento da Grã-Bretanha. Era um sistema simples de classificação de terras compreendendo sete categorias representadas por letras e cores (florestas e bosques, prados, terras aráveis, charnecas, jardins e pomares, terrenos baldios e terras improdutivas, lagoas e lagos).

Na década de 1940. Francis J. MARSCHNER (1950) fez o mapeamento do uso das terras dos Estados Unidos por fotografias aéreas. Tal trabalho estabeleceu uma abordagem interdisciplinar expandindo os métodos cartográficos na descrição de dados físicos e econômicos.

Os dados de sensores remotos, no caso das fotografias aéreas, sempre compuseram a base de dados para o mapeamento de uso das terras e revestimento dos solos. Os mesmos têm demonstrado grande sucesso e utilidade para o inventário e mapeamento em grandes escalas (ANDERSON et al., 1979).

Por volta de 1946 criou-se a Comissão de Levantamento da Utilização da Terra no Mundo durante um Congresso em Lisboa (KELLER, 1969). Com objetivo de estabelecer uma classificação para uso mundial e dando início a alguns estudos pilotos no Brasil sob a responsabilidade do Instituto Brasileiro de Geografia - IBGE. 
Desde a criação desta Comissão e a aprovação da utilização da classificação proposta, a sua divulgação entre os países-membros da União Geográfica Internacional (UGI) tornou-se gradual e crescente. Pois, a promoção do mapeamento da utilização da terra transformou-se em um registro da realidade para diferentes países do mundo.

KELLER (1969) completa que por ocasião do Congresso realizado em Washington, em 1952, esta comissão redigiu um relatório que confirmava a utilidade dessa classificação por esclarecer os conhecimentos e a importância na distribuição real das diferentes formas de uso do espaço.

Por mais que os dados advindos desta distribuição não resolvessem os problemas da população mundial acerca do seu suprimento de alimentos ou no melhoramento de áreas subdesenvolvidas, ele ainda possibilitava a criação de um Inventário Mundial com o uso da terra fundamental e único.

E por instrução da própria Comissão em seu relatório era obrigatória a interpretação de todas as áreas levantadas, onde nos mapas deveriam apresentar memórias explicativas acerca dos temas desenvolvidos.

KELLER (1969) defendia a importância dos mapas, pois não existia um meio mais eficiente e completo de mostrar a localização atual e a distribuição das várias modalidades de utilização da terra, além do conhecimento das mudanças nos padrões de distribuição.

Os mapas se baseavam na única e exclusiva observação e não no resultado de interpretação e desenvolvimento de idéias. Com a classificação proposta pela Comissão, o mapa deveria registrar fatos e não apenas opiniões sobre a realidade.

Assim, o principal objetivo do levantamento mundial foi registrar o uso atual da terra em todas as partes do mundo por um sistema único e universal de classificação. E foram usados todos os materiais necessários como: materiais básicos, levantamento de campo, fotografias aéreas, além de dados estatísticos e econômicos.

ANDERSON et al.(1979) comentam que um sistema de classificação deve atender a receptividade às entradas de dados de fontes convencionais e também de plataformas de satélite, as quais constituem uma verdadeira estrutura de categorias de estudos detalhados sobre o uso da terra.

O autor ainda completa que este sistema deve ser prioritariamente realizado por órgãos regionais, estaduais e locais, os quais têm total conhecimento de todos os recursos naturais em suas respectivas regiões. Os mesmos devem ainda ser ajustados e agregados crescentemente ao longo do tempo e espaço. 
A classificação da utilização da terra apresentada pela União Geográfica Internacional (UGI) e defendida pela Comissão continham os seguintes modos de uso e suas respectivas cores associadas (TABELA 1).

TABELA 1 - Modalidades de usos da terra com sua respectiva cor associada.

\begin{tabular}{c|l|c}
\hline \hline No. & \multicolumn{1}{|c|}{ MODALIDADES DE USO DA TERRA } & COR ASSOCIADA \\
\hline 1. & Estabelecimentos humanos e áreas associadas não-agrícolas & Vermelho claro e escuro \\
\hline 2. & Horticultura & Púrpura escura \\
\hline 3. & Culturas arbóreas e outras culturas perenes & Púrpuro claro \\
\hline 4. & Cultivos anuais I (contínuos ou de rotação de culturas) & Marrom escuro \\
\hline 5. & Cultivos anuais II (rotação de terras) & Marrom claro \\
\hline 6. & Pastagens permanentes plantadas ou naturais melhoradas & Verde claro \\
\hline 7. & Pastagens naturais não melhoradas & Amarelo e laranja \\
\hline 8. & Floresta densa & Verde escuro \\
\hline 9. & Floresta Aberta & Verde médio \\
\hline 10. & Floresta "Scrub" & Verde oliva \\
\hline 11. & Floresta pantanosa & Verde azulado \\
\hline 12. & Floresta com cultivo subsidiário & Verde com pontos marrons \\
\hline 13. & Áreas pantanosas (não florestais) & Azul \\
\hline 14. & Terras improdutivas & Cinzento \\
\hline \hline
\end{tabular}

FONTE: Adaptado de KELLER (1969).

Na TABELA 2 mostramos a descrição de cada forma de uso da terra depois de cuidadosos estudos e discussões por diversos especialistas mundiais pertencentes à União Geográfica Internacional (UGI).

TABELA 2 - Descrição das formas de usos da terra.

\begin{tabular}{c|l}
\hline \hline No. & \multicolumn{1}{|c}{ DESCRIÇÃO DAS FORMAS DE USO DA TERRA } \\
\hline 1. & Áreas ocupadas pelas cidades e pelos estabelecimentos industriais \\
\hline 2. & Cultivos intensivos de hortaliças e frutas (não arbóreas) \\
\hline 3. & Culturas arbóreas permanentes e perenes feitas sem rotação de cultura \\
\hline 4. & Cultivos contínuos (monocultura) ou de rotação de culturas fixa ou variável de pousio regulares \\
\hline 5. & Cultivos com rotação de terras de sofrem pousio longos \\
\hline 6. & Pastagens com adubação, calagem ou semeadura para pastoreio direto ou para feno \\
\hline 7. & Pastagens de criação extensiva sem uso de fertilizantes, mas com uso de queimadas \\
\hline 8. & Floresta de copas que se tocam \\
\hline 9. & Floresta de copas esparsas com presença de gramíneas ou vegetação herbácea \\
\hline 10. & Floresta mista \\
\hline 11. & Floresta em solo encharcado \\
\hline 12. & Áreas de cultura itinerante com derrubada de matas por longos períodos para cultivo \\
\hline 13. & Áreas não florestais \\
\hline \hline
\end{tabular}




\section{4. Áreas rochosas, areais, dunas, etc. \\ FONTE: Adaptado de KELLER (1969).}

É claro que com o desenvolvimento e melhoria de novas classificações estes usos foram sendo modificados. Porque era obvia a existência de outros tipos de usos determinantes de certas regiões.

No Brasil, mais precisamente nas dependências do IBGE o levantamento utilizando a partir das recomendações da Comissão de Utilização da Terra da UGI teve outra linha de pesquisa de acordo com as observações de campo e a escala de mapeamento. Foram também utilizadas fotografias aéreas entre outros insumos que melhor direcionaram as informações acerca das especificidades de cada região mapeada.

As fotointerpretações feitas em fotografias aéreas e por vezes com auxílio de estereoscópios atreladas aos estudos em gabinete advindos de trabalho de campo puderam apresentar grande economia de gastos e tempo. Além, de facilitar a identificação da rede hidrográfica, as estradas de ferro e de rodagem, as sedes das fazendas, as vilas, os povoados, as indústrias rurais e as cidades (KELLER, 1969).

Assim, o mapeamento da utilização da terra do IBGE foi classificado diferentemente da proposta da Comissão de Uso da Terra da UGI em escalas 1: 250.000 se estendendo para o milionésimo (TABELA 3).

TABELA 3 - Classificação do IBGE para classes de uso da terra.

\begin{tabular}{|c|c|c|}
\hline CATEGORIA & CLASSES DE USO DA TERRA & OCUPAÇÃO \\
\hline A & UTILIZAÇÃO NÃO-AGRÍCOLA & $\begin{array}{l}\text { 1. Áreas residenciais; } \\
\text { 2. Áreas industriais e de mineração; } \\
\text { 3. Áreas comerciais; } \\
\text { 4. Instalações para transportes e } \\
\text { comunicações; } \\
\text { 5. Áreas de utilidade pública; } \\
\text { 6. Áreas de recreação; } \\
\text { 7. Áreas de serviço; } \\
\text { 8. Áreas de serviço agrícola }\end{array}$ \\
\hline B & TERRAS AGRÍCOLAS & $\begin{array}{l}\text { 1. Horticultura; } \\
\text { 2. Culturas permanentes ou perenes; } \\
\text { 3. Culturas anuais; } \\
\text { a. contínua; } \\
\text { b. com rotação fixa ou variável sem } \\
\text { pousio; } \\
\text { c. com rotação fixa ou variável com } \\
\text { pousio; } \\
\text { d. rotação de culturas e pastagens; } \\
\text { e. rotação de terras. } \\
\text { 4. Pastagens; } \\
\text { a. naturais e semi-naturais; } \\
\text { b. artificiais; }\end{array}$ \\
\hline
\end{tabular}




\begin{tabular}{c|l|l}
\hline \hline C & FLORESTAS & $\begin{array}{l}\text { 1. Florestas não exploradas; } \\
\text { 2. Florestas exploradas; } \\
\text { 3. Áreas reflorestadas; }\end{array}$ \\
\hline $\mathrm{D}$ & ÁGUAS & $\begin{array}{l}\text { 1. Águas correntes naturais e artificiais; } \\
\text { 2. Reservatórios naturais e artificiais; }\end{array}$ \\
\hline F & TERRAS IMPRODUTIVAS & $\begin{array}{l}\text { 1. Áreas improdutivas naturais; } \\
\text { 2. Áreas improdutivas artificiais; }\end{array}$ \\
\hline \hline
\end{tabular}

FONTE: Adaptado de KELLER (1969).

A classificação elaborada pelo IBGE devido seu grande número de modalidades de uso não abrangia todas as diferentes intensidades de cores sugeridas pela Comissão da UGI. Adotou-se então a utilização também de símbolos ou letras para distinguir as diferentes formas de aproveitamento do solo (KELLER, 1969).

O IBGE também utilizou em anexo um relatório que seguia algumas recomendações da Comissão da UGI, onde para complementar foram apresentados os aspectos físicos, técnicos e econômicos da utilização da terra de cada região mapeada.

Foram também incluídas na classificação do IBGE as características externas e internas da utilização da terra. As quais apresentavam as condições externas ou internas acerca do nível tecnológico geral, grau de desenvolvimento econômico e social, padrão de vida, condições de localização em termos de acessibilidade aos meios de transporte, a mercados, a centros de beneficiamentos e comercialização da produção agrícola entre outros (KELLER, 1969).

Mas, apesar de profundos estudos e pesquisas para o desenvolvimento e elaboração de uma classificação de utilização da terra apoiada na Comissão da UGI para o Brasil, o IBGE não tinha estabelecido um caráter definitivo para a proposta.

É claro que deveriam ser realizados novos estudos acerca desta classificação por pesquisadores dos centros pesquisa geográfica e centros universitários espalhados por todo o país. Pois, as diferentes condições naturais presentes nas regiões eram o fator limitante que culminava em novos experimentos sobre a utilização da terra.

KELLER (1969) diz que o maior significado científico e prático sobre o mapeamento da utilização da terra está na fundamentação clara e objetiva da pesquisa de tipologia da agricultura. Assim, como dos diversos tipos de uso existentes quer seja por atividades industriais, agricultáveis, urbanas, recreativas entre outros.

Mas, para ANDERSON et al.(1979) não existe uma classificação de uso da terra e revestimento do solo que seja única e ideal. Com o desenvolvimento de novos estudos, levantamentos com diferentes dados de sensores remotos ou não e trabalhos de campo a classificação segue outro rumo da que foi proposta. 
Estes autores dizem que para a realização do mapeamento do uso da terra e do seu revestimento não podemos nos basear em apenas um sistema de classificação. Pois, neste processo tende-se a utilizar a subjetividade, mesmo quando se usa uma abordagem numérica objetiva.

Um mapeamento ou um inventário detalhado tem um tempo de validade, ele não pode ser utilizado por mais que um curto período devido principalmente pela modificação e dinâmica trazidos pela demanda dos recursos naturais existentes em uma região.

Assim, as classificações apenas atendem as necessidades do especialista ou usuário em determinado tempo. Cabendo sempre uma melhoria baseada em outras opiniões ou estudos que vêm a melhorar essa classificação.

ANDERSON et al. (1979) definem para o mapeamento do uso e revestimento ou cobertura da terra um Sistema de Classificação a partir dos tipos de categorização. Os quais são relacionados com sistemas para classificação de potencialidades do solo, vulnerabilidade a certas práticas de manejo, e potencial para qualquer atividade em particular ou valor da terra intrínseca ou não (especulativa).

E quando um sistema de classificação de uso e cobertura da terra utiliza dados de sensores orbitais, ANDERSON (1971) diz que é necessário seguir determinados critérios como:

1- O nível mínimo de precisão utilizado para a interpretação e identificação de categorias de uso e cobertura deve ser de $85 \%$;

2- A precisão da interpretação destas diferentes categorias também deve ser aproximadamente a mesma;

3- Resultados repetitivos devem ser os mesmos para qualquer interprete ou tipo de sensor;

4- O sistema de classificação utilizado deve atender pequenas e grandes áreas;

5- No caso de revestimento de vegetação e de solo, os mesmos devem fornecer substituição às atividades desconhecidas;

6- O sistema de classificação deve ser capaz de utilizar dados sensores de qualquer época do ano;

7- Deve-se conseguir definir subcategorias adquiridas de levantamentos de campo ou de dados de sensores remotos em maior ou menor escala;

8- Devem-se agregar categorias quando necessário;

9- Deve-se poder comparar dados de uso e revestimento anteriormente mapeados; 
10- Devem-se identificar claramente os múltiplos tipos de uso e revestimento quando possível.

As informações provenientes destes dados a partir de sensores são indiscutivelmente de grande valia. Pois, os equipamentos de SR estão baseados em muitas características da superfície da terra, o que pode nos fornecer informações sobre um revestimento natural ou artificial. Mas, é impossível decifrar com estes dados o registro destas atividades.

O que estamos falando é que as atividades exercidas não podem ser identificadas com sua respectiva classe de uso ou cobertura. Ou seja, as atividades recreativas extensas em grandes áreas não são identificáveis com os dados de SR.

Para isso necessitamos de informações complementares que não são visualmente claras nos dados de sensores como: os mapas de propriedades das terras com discriminação dos usos que podem ser parques, refúgios de caça, distritos de conservação de água, etc (ANDERSON et al., 1979).

Assim, devemos saber que não só os dados dos sensores podem nos trazer bons resultados no levantamento do uso e cobertura do solo. Existem outros dados que podemos também ter grandes êxitos na solubilidade das dúvidas encontradas nos dados sensores como: mapas topográficos, mapas de estradas, mapas urbanos detalhados entre outros.

Desta forma, necessitamos de um Quadro de Referência que nos permita fazer uma melhor organização e hierarquização das informações obtidas de todas as fontes. Esse quadro proposto por ANDERSON et al. (1979) apud NOVO (1989) possibilitará a inserção ou incorporação de informações advindas de quaisquer fontes e aquisições de dados.

ANDERSON et al.(1979), neste quadro, utilizam níveis de classificação de uso da terra que podem iniciar desde o Nível I contemplando a máxima generalização da informação e findar no Nível IV, onde se atinge seu detalhamento consideráveis. Claro, que estes níveis podem ser variados e diferentes devido às características específicas da própria área de estudo.

Para o mapeamento do uso e cobertura da terra nos atentaremos no Nível I, pois utilizaremos dados orbitais (SR). É claro que durante a pesquisa tentaremos coletar informações isoladas com o intuito de um melhor detalhamento o que nos aproximará do Nível IV. É importante ressaltar que esse Sistema de Classificação foi desenvolvido na Universidade de Michigan (JENSEN, 1983). 
No entanto, a importância do uso de fotografias aéreas que se classificam segundo ANDERSON et al.(1979) no Nível II, se fará quando regiões identificadas nas imagens orbitais apresentarem dúvidas de interpretação ou classificação.

De acordo com exposto apresentamos a TABELA 4 contendo as principais características do Sistema de Classificação de uso e cobertura da terra por SR elaborado por JENSEN (1983) apud NOVO (1989).

TABELA 4 - Sistema de classificação de uso e cobertura da terra por SR.

\begin{tabular}{c|c|c|c|c}
\hline \hline CRITÉRIOS & NÍVELI & NÍVEL II & NÍVEL III & NíVEL IV \\
\hline $\begin{array}{c}\text { UTILIZAÇÃO } \\
\text { PRINCIPAL }\end{array}$ & NACIONAL & NACIONAL & $\begin{array}{c}\text { ESTADUALI } \\
\text { REGIONAL }\end{array}$ & LOCAL \\
\hline $\begin{array}{c}\text { ESCALA DE } \\
\text { MAPEAMENTO }\end{array}$ & $\begin{array}{c}1: 250.000- \\
1: 1000.000\end{array}$ & $\begin{array}{c}1: 125.000- \\
1: 250.000\end{array}$ & $\begin{array}{c}1: 50.000- \\
1: 125.000\end{array}$ & $\begin{array}{c}1: 25.000- \\
1: 50.000\end{array}$ \\
\hline $\begin{array}{c}\text { MÍNIMA UNID. } \\
\text { MAPEÁVEL }\end{array}$ & $94-1480$ ha & $24-94$ ha & $4-94$ ha & $0,8-4$ ha \\
\hline $\begin{array}{c}\text { BASE PARA } \\
\text { CLASSIFICAÇÃO }\end{array}$ & COBERT. SOLO & COBERT. SOLO & COBERT.IATIVIDADE & COBERT.IATIVIDADE \\
\hline FONTES DE DADOS & INTERPRET. & INTERPRET. & INTERP. IMAGEM E & $\begin{array}{c}\text { INTERP. IMAGEM E } \\
\text { DADOS DE CAMPO }\end{array}$ \\
\hline \hline
\end{tabular}

FONTE: JENSEN (1983).

A partir da TABELA 4 descreveremos as formas de uso e cobertura da terra classificadas pelo sistema do U. S. Geological Survey - USGS (ANDERSON et al., 1979) utilizando os Níveis I e II, mais generalizados (TABELA 5). Incluiremos também as respectivas cores associadas com base na versão modificada do esquema de cores do Levantamento mundial de uso da terra (International Geographical Union, 1952).

Esse sistema apresentado atende a três principais atributos do processo de classificação proposto por GRIGG (1965) apud ANDERSON et al. (1979): a) identifica as categorias simplesmente utilizando a terminologia já aceita; b) permite que a informação seja transmitida; e c) permite que se façam generalizações indutivas.

TABELA 5 - Classificação do USGS para categorias de uso da terra.

\begin{tabular}{l|l|c}
\hline \hline \multicolumn{1}{c|}{ NÍVEL I } & \multicolumn{1}{c}{ NÍVEL II } & COR ASSOCIADA \\
\hline & 11. Residencial; & \\
& 12. Comercial e Serviços; & \\
1. TERRA URBANA OU & 13. Industrial; & VERMELHO \\
CONSTRUÍDA & 14. Transportes, Comunicações e Utilidades; & (Münsel 5R 6/12) \\
& 15. Complexos Industriais e Comerciais; & \\
& 16. Terra Urbana ou Construída Mista; & \\
& 17. Terra Urbana Diversa ou Construída. & \\
\hline \hline
\end{tabular}




\begin{tabular}{|c|c|c|}
\hline 2. TERRA AGRÍCOLA & $\begin{array}{l}\text { 21. Terra de Cultura e Pastagem; } \\
\text { 22. Pomares, Bosques, Vinhedos, Viveiros e Áreas de } \\
\text { Horticultura Ornamental; } \\
\text { 23. Atividades de Criação Confinada; } \\
\text { 24. Ouros tipos de Terra Agrícola. }\end{array}$ & $\begin{array}{l}\text { CASTANHO CLARO } \\
\text { (Munsell 5YR 7/4) }\end{array}$ \\
\hline 3. PASTAGENS & $\begin{array}{l}\text { 31. Pastagem Herbácea; } \\
\text { 32. Pastagem com Arbusto e Carrasco; } \\
\text { 33. Pastagem Mista. }\end{array}$ & $\begin{array}{l}\text { LARANJA CLARO } \\
\text { (Munsell 10YR 9/4) }\end{array}$ \\
\hline 4. TERRA FLORESTAL & $\begin{array}{l}\text { 41. Terra de Floresta Decídua; } \\
\text { 42. Terra de Floresta Sempre Verde; } \\
\text { 43. Terra de Floresta Mista. }\end{array}$ & $\begin{array}{c}\text { VERDE } \\
\text { (Munsell 10GY 8/5) }\end{array}$ \\
\hline 5. ÁGUA & $\begin{array}{l}\text { 51. Cursos d'água e Canais; } \\
\text { 52. Lagos; } \\
\text { 53. Reservatórios; } \\
\text { 54. Baías e Estuários. }\end{array}$ & $\begin{array}{l}\text { AZUL ESCURO } \\
\text { (Munsell 10B 7/7) }\end{array}$ \\
\hline 6. TERRA ÚMIDA & $\begin{array}{l}\text { 61. Terra Úmida Florestada; } \\
\text { 62. Terra Úmida Não Florestada; }\end{array}$ & $\begin{array}{c}\text { AZUL CLARO } \\
\text { (Munsell 7.5B 8.5/3) }\end{array}$ \\
\hline 7. TERRA ÁRIDA & $\begin{array}{l}\text { 71. Planícies Salgadas Secas; } \\
\text { 72. Praias; } \\
\text { 73. Outras Áreas de Areia que não Praias; } \\
\text { 74. Rocha Nua Exposta; } \\
\text { 75. Minas a céu-aberto, Pedreiras e Minas de } \\
\text { Cascalho; } \\
\text { 76. Áreas de transição; } \\
\text { 77. Terra Árida Mista. }\end{array}$ & CINZA (Munsell N8/0) \\
\hline 8. TUNDRA & $\begin{array}{l}\text { 81. Tundra de Arbustos e Macega; } \\
\text { 82. Tundra Herbácea; } \\
\text { 83. Tundra de Solo Nu; } \\
\text { 84. Tundra Úmida; } \\
\text { 85. Tundra Mista. } \\
\end{array}$ & $\begin{array}{l}\text { CINZA-ESVERDEADO } \\
\text { (Munsell 10G 8.5/1.5) }\end{array}$ \\
\hline 9. NEVE OU GELO PERENE & $\begin{array}{l}\text { 91. Campos de Neve Perene; } \\
\text { 92. Geleiras; }\end{array}$ & $\begin{array}{c}\text { BRANCO } \\
\text { (Munsell N 10/0) }\end{array}$ \\
\hline
\end{tabular}

FONTE: ANDERSON et al. (1979).

Não descreveremos esta classificação, pois a mesma foi proposta passível de um maior refinamento na base com formas de utilização mais amplas e variadas. Está destinado ao uso em atividades de planejamento e administração de uso da terra.

$\mathrm{Na}$ verdade nem todas as classes existem em determinadas regiões e por isso é importante que haja uma flexibilidade nesta categorização para níveis de maior detalhe. Desta forma, não achamos necessária a ilustração de cada classe, pois assim estaremos induzindo aos especialistas e usuários que desenvolvam as suas próprias necessidades particulares, as quais se compatibilizarão as diversas regiões afins.

Como vimos as informações adquiridas dos dados dos sensores são importantes para o mapeamento de uso e cobertura da terra principalmente devido à resolução espacial do dado. Ou seja, a escolha de sensores que tenham uma melhor capacidade de individualizar dois objetos diferentes entre si ou determinada feição na superfície terrestre será aquele mais indicado. 
Por isso é inegável a necessidade da utilização de diversos dados dos sensores, pois os mesmos podem suprir e sanar todas as dúvidas provenientes de um sistema de classificação. Estes dados devem ser selecionados para fornecer uma gama de informações sobre a superfície terrestres independente da altitude ou escala.

Devemos atentar também que existem áreas, as de terreno com relevo muito acentuado, por exemplo, que não podem utilizar os mesmos dados de sensores remotos que as das áreas planas. A solução é utilizar dados do sensor SRTM ou os de Radar para amenizar ou até mesmo evitar problemas de escala.

Outro fator muito importante para o mapeamento do uso e cobertura da terra é a interpretação acerca dos objetos identificados e visualizados nos dados dos sensores. Pois, através destes podemos obter de forma rápida e segura uma classificação atualizada das diferentes estruturas espaciais advindas dos processos de uso e ocupação da terra (RODRIGUEZ, 2000).

Para isso o intérprete utiliza padrões, tonalidades, texturas, formas e associações no terreno a fim de obter informações sobre atividades existentes na superfície da terra, com o intuito de identificar e constituir informações acerca o revestimento do solo (ANDERSON et al., 1979).

Desta forma, é de grande valia o levantamento e a elaboração do mapeamento de uso e cobertura da terra, pois este atende e satisfaz os interesses para os planejamentos regionais de uma região. A sua utilização a partir do conhecimento das diversas classes de uso fornecem informações primordiais para o desenvolvimento da organização agrária de um território, assim como da preservação de seus recursos naturais.

ANDERSON et al.(1979) afirmam que uma nação em crescente desenvolvimento deve conhecer com clareza as informações pertinentes as atividades exercidas em seu território e por conseguinte fornecer melhorias na tomada de decisões benéficas para populações futuras.

Outra vantagem que é fornecida com o mapeamento do uso e cobertura da terra é o conhecimento do desenvolvimento desenfreado da política agrária de um país que provoca a migração crescente, assim como a transformação total da paisagem (ALENCAR et al., 1996).

ALVES et al. (1998), comentam que o levantamento do uso e cobertura da terra permite estimar o aumento de áreas desmatadas, onde extensões significativas de floresta não poderiam ser monitoradas facilmente sem o recurso dos satélites de sensores remotos. 
Já VALENTE (1998), afirma que para caracterizar e monitorar os variados usos da terra são necessárias informações atualizadas e confiáveis referentes à questão. E essas informações são importantes para que os órgãos governamentais possam ter conhecimento da situação atual dos recursos naturais e assim lançar diretrizes para a elaboração de novas políticas ambientais.

Para RIBEIRO (1998), o conhecimento e o mapeamento do uso da terra são fundamentais para o entendimento dos processos de mudanças globais, especialmente em regiões de grande extensão que podem demandar muito tempo e custo. Assim, os dados dos sensores atrelados a softwares constituem-se elementos indispensáveis ao planejamento das atividades agropastoris, na elaboração de projetos de engenharia, no levantamento e conservação de solos, nos mapeamentos multitemporais, na discriminação do uso e ocupação da terra entre outros.

Hoje com o surgimento de sistemas de classificação automática, os mapeamentos tornaram-se poderosas armas na contribuição para os estudos de áreas desflorestadas em formações florestais tropicais (DUARTE et al., 1999). Pois, a demanda cada vez mais crescente do estudo dos recursos naturais e a sua rápida diminuição em escala global têm imposto o levantamento periódico pelos órgãos governamentais.

A crescente pressão da ocupação humana tem proporcionado a análise das mudanças na cobertura vegetal através da utilização de dados multiespectrais, favorecendo de maneira sustentável tanto para o meio ambiente como para o homem (WATRIN, 1998). O que nos permite tentar controlar a ocupação desordenada sem qualquer tipo de planejamento urbano e ambiental, a qual antes não podia ser monitorada e nem evitada.

\subsubsection{1 $\quad$ Sensoriamento Remoto (SR)}

Ao longo da história o homem veio sempre procurando desenvolver formas de decifrar e investigar a Terra. Pois, seu intuito de desbravamento desta era em favor da busca de alimento, defesa e melhorias para sua própria sobrevivência.

Têm-se como registro que os primórdios das civilizações procuravam descrever suas aventuras pelas terras desconhecidas através de sinais e símbolos. Segundo SILVA (1943) os primitivos daquela época criavam "uma espécie de morfologia do mundo", onde se podia narrar e descrever todos os acontecimentos identificados de característica única e exclusivamente local.

Os desbravamentos não se resumiam apenas na parte terrestre. Já no século XV iniciavam-se as descobertas de "novas terras" por viagens marítimas. As quais trouxeram ao 
homem a idéia da esfericidade da Terra. E desta forma surgem o desenvolvimento de novas ciências focadas no descobrimento mais detalhado da geografia da Terra.

Já em 1800, se tinha certo conhecimento do Planeta através de relatos de viagens, escritos literários entre outras informações pertinentes sobre sua geografia (MORAES, 1983). Porém, ainda existiam áreas a serem representadas e descritas.

E para melhorar os seus conhecimentos sobre a geografia da Terra, surgem as fotografias aéreas, entre os séculos XIX e XX. Elas representavam um importante auxilio na obtenção de informações do terreno, principalmente no uso militar. Dando-se inicio a "Era do Sensoriamento Remoto".

As primeiras fotografias aéreas foram usadas em 1849 por engenheiros militares americanos para a obtenção e confecção de mapas topográficos. Em 1858, Gaspard Felix Tournachon (Nadar) fotografou a bordo de um balão a paisagem da superfície terrestre da vila Petit Bicètre perto de Paris (LIU, 2006) (FIGURA11). As principais fotografias desta época auxiliaram durante a Guerra Civil dos Estados Unidos no reconhecimento militar.

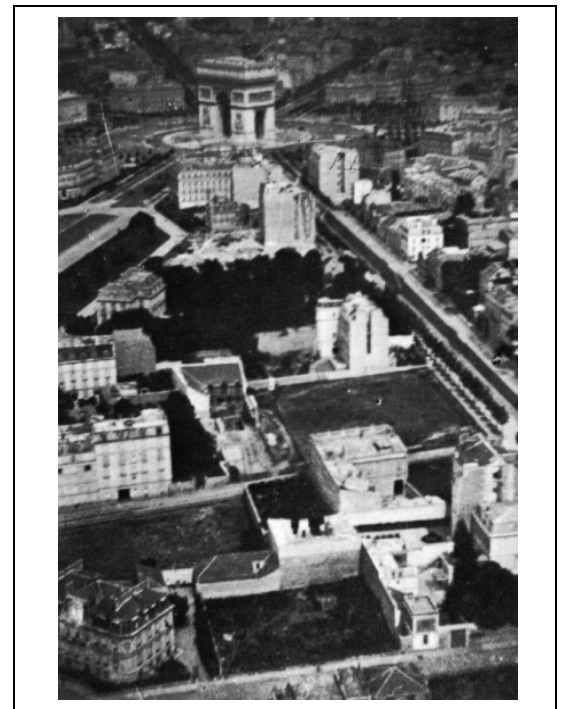

FIGURA 11 - Vila Petit Bicètre perto de Paris.

FONTE: JENSEN, 2009

Em 1898, surgem as câmeras fotográficas desenvolvidas no levantamento aéreo. Dando-se destaque à Rússia, pioneira na obtenção de fotografias com sobreposições de horizonte a horizonte.

Os aviões são construídos rapidamente e aperfeiçoados ao longo da primeira década do século XX. Os irmãos Wright satisfazem as especificações militares viabilização assim, o fornecimento de fotografias para o exército americano.

Os rápidos avanços no desenvolvimento do mapeamento fotográfico foram destacados pela Primeira Guerra Mundial. Em 1909, se originou as fotografias aéreas com o Rodríguez, A. C. M. 
uso do filme infravermelho proporcionando a identificação de áreas camufladas de folhagem natural.

Em 1911 o exército francês utilizou fotografias aéreas para planejar suas ações durante a crise marroquina, e pelo início da guerra, o exército alemão já estava usando câmeras em zepelins.

O britânico Royal Flying Corps utilizou extensivamente as fotografias aéreas no ano em que as forças britânicas atacaram Neuve-Chapelle. A manobra foi realizada com base em mapas elaborados exclusivamente a partir de reconhecimento fotográfico, a primeira dessas medidas já tomadas.

A Alemanha, logo após a abertura das hostilidades, havia começado a fotografar toda a região ocidental numa base quinzenal. Até o final da guerra, o exército havia produzindo cerca de quatro mil fotos por dia.

E antes da Segunda Guerra Mundial, as técnicas de fotografias aéreas foram se aprimorando cada vez mais para a aplicação em levantamentos de recurso naturais, tais como formações geológicas, florestais, solos, agricultura e na confecção de mapas cartográficos (LIU, 2006).

Com advento da evolução da ciência e da tecnologia espacial, ao lado das fotografias aéreas foram sendo desenvolvidos por modernos equipamentos sensores a bordo de satélites que "fotografam a Terra" com detalhes a centenas de quilômetros de distância (NOVO, 1989).

Os satélites evoluíram logo após a Segunda Guerra Mundial, e os Estados Unidos foram os que mais investiram nas tecnologias espaciais. Criando um Centro de Pesquisas "National Aeronautics and Space Administration - NASA" em 1958 (LIU, 2006).

Durante os anos 50 muitos satélites foram lançados ao espaço para usos militares e civis. Para a comunidade acadêmica de pesquisas somente foram disponibilizados apenas os de uso civil orientados ao SR e às aplicações meteorológicas. Existiam as plataformas tripuladas que coletavam fotografias da superfície terrestre por espaçonaves e as nãotripuladas que capturavam imagens da Terra por satélites em orbitas estipuladas previamente (NOVO, 1989).

A primeira espaçonave que obteve fotografias foi a do satélite Mercury em 1961. Depois, foram utilizadas missões da série Gemini com a coleta de imagens com filme infravermelho especificamente estabelecido para o reconhecimento dos recursos naturais.

Somente em 1967 foram obtidas as fotografias coloridas para o levantamento e estudo dos recursos terrestres abordo das missões da série Apollo 6. O Apollo 9 apoiou as 
análises dos dados obtidos para fortalecer o desempenho do Programa ERTS, mais conhecido como Landsat, o qual foi o primeiro satélite lançado orientado ao SR não tripulado (NOVO, 1989).

Em 1973, foi lançada a estação espacial Skylab pela NASA que permitiu a utilização da coleta de dados por diferentes sistemas sensores desde o infravermelho passando pelo visível, microondas até o radar.

Atualmente, temos o Space Shuttle (ônibus espacial) com capacidade para executar missões e retornar a Terra. Sua primeira coleta de informações foi em 1981 e sua ultima em 2000 quando se iniciou a utilização da interferometria com apoio de duas antenas que permitem a avaliação do perfil de altitude para a criação do modelo digital tri-dimensional da Terra (NOVO, 1989; VALERIANO, 2004).

O ERTS mais conhecido como Landsat foi lançado em 1975 e é o primeiro satélite da série Landsat. Sua construção foi um melhoramento do NIMBUS possuindo dois sensores o MSS (Multispectral Scanner Subsystem) e o RBV (Return Beam Videocon). Desde então já foram lançados cerca de 7 satélites da série Landsat.

O Landsat 5 apesar de lançado em 1984 ainda continua operando, o qual possui dois sensores o TM (Thematic Mapper) e o MSS. O Landsat 7 com o sensor ETM ${ }^{+}$(Enhanced Thematic Mapper) foi o ultimo lançado em 1999.

Mas, não foram apenas os americanos que desenvolveram e construíam os satélites. Outros países se sentiram na necessidade de desenvolvimento de sua própria tecnologia espacial como os franceses com a série SPOT em 1985. E também os brasileiros com apoio dos chineses no Programa Missão Espacial Completa Brasileira (MECB), que em 1993 lançaram o CBERS (China Brazil Earth Resources Satellite).

Em 1999 foi lançada a primeira plataforma TERRA do Programa EOS (Earth Observing System) que visa o estudo e entendimento dos processos de mudanças globais envolvendo investigações sobre o ciclo da água, ciclo de energia, oceano, química da troposfera, as três camadas da estratosfera, interação dos ecossistemas terra-água, geleiras e os processos da própria Terra (RUDORFF et al., 2007).

Do Programa EOS surge seu principal instrumento, o sensor MODIS (ModerateResolution Imaging Spectroradiometer) percussor do sensor AVHRR (Advanced Very High Resolution Radiometer) da série NOAA (National Oceanic and Atmospheric Administration) administrado para o monitoramento de tempo e clima. Este sensor também é percussor do CZCS (Coastal Zone Color Scanner) que captava variações sutis da refletância nas águas oceânicas. 
A segunda plataforma do Programa EOS chamada ACQUA foi lançada em 2002 e seu principal objetivo era complementar os estudos e as pesquisas para a plataforma TERRA como a evaporação dos oceanos, vapor d água na atmosfera, nuvens, precipitação, umidade da superfície da terra, gelo no mar, gelo na terra e cobertura de neve. Além, de fluxos de energia radiativa, aerossóis, cobertura vegetal, fitoplâncton e matéria orgânica dissolvida nos oceanos, e temperaturas: do ar, da terra, e da água (RUDORFF et al., 2007).

O Sensoriamento Remoto (SR) compreender o campo de captar, explorar e apresentar fotografias, imagens ou dados obtidos por uma máquina comum de fotografia, balões e/ou aviões (câmeras) ou satélites (sensores) da paisagem ou superfície terrestre sem o contato físico direto.

Na literatura são encontradas várias definições do que é SR. Para LILLESAND e KIEFER (1987), o SR é a ciência de obter informações de um determinado objeto, área ou fenômeno através da análise dos dados adquiridos sem o contato direto com os objetos investigados. NOVO (1989) define ainda o SR como sendo a utilização de modernos sensores, a bordo de aeronaves, espaçonaves, com o objetivo de estudar o ambiente terrestre mediante o registro e da análise das interações entre a Radiação Eletromagnética (REM) e as substâncias existentes na superfície terrestre em suas mais diversas manifestações.

NOVO (1989) destaca que o SR é definido como sendo a tecnologia que permite a aquisição de informações sobre objetos sem o contato físico com eles. Os objetos que são mencionados nesta definição podem ter aspectos naturais como: um rio, uma área de agricultura, etc., ou artificiais como: uma cidade, uma casa, uma indústria, um carro, etc.

E para se compreender, medir, identificar, interpretar e analisar estes objetos no espaço geográfico é necessário pelo menos conhecer suas propriedades físico-químicas. Ou seja, todo objeto encontrado na natureza se apresenta com formas, quantidades, qualidades e aspectos diferentes entre si, sem falar em suas outras características físicoespecíficas.

A identificação destas características nestes objetos é proveniente da quantificação de energia solar ou radiação eletromagnética ou energia eletromagnética (REM) quando esta incide sobre a superfície da Terra. E para isso se utiliza como fonte de radiação o $S O L$ no caso de "Sensores Passivos", que estão a bordo de aeronaves e satélites.

Existem também os "Sensores Ativos" presentes nos radares e no laser que são capazes de emitirem sua própria energia e receberem um sinal de retorno. Os quais podem detectar informações sobre a superfície terrestre sob qualquer condição atmosférica diferindo dos sensores passivos que não apresentam esta vantagem. 
A REM é uma forma de transmissão da energia que consiste na aceleração de uma carga elétrica que provoca perturbações no campo Elétrico (E) e Magnético ( $M)$, se propagando (C) no vácuo (FIGURA 12) (NOVO,1989). Quando essa radiação interage com o objeto, o resultado desta interação dependerá das propriedades elétricas e magnéticas deste.

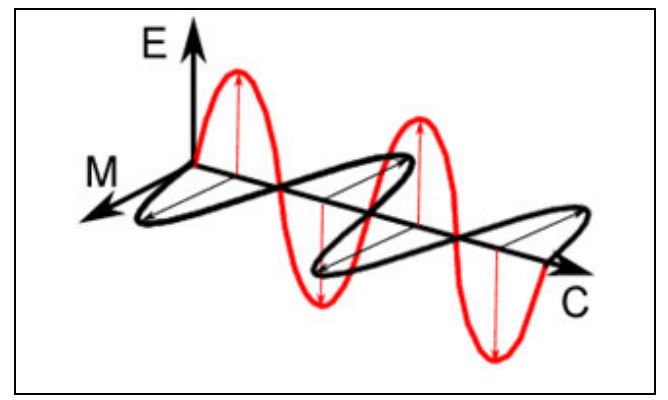

FIGURA 12 - Esquema de uma onda eletromagnética.

FONTE: MOREIRA (2001), p.20

A REM se propaga em forma de ondas eletromagnéticas com velocidade da luz (300.000km por seg.). Essa radiação é medida em frequência e comprimento de onda.

A frequência de onda corresponde ao número de vezes que uma onda se repete por unidade de tempo. Ou seja, quanto maior for o número de ondas maior será a frequência e vice-versa. Já o comprimento de onda é a distância entre dois picos de ondas sucessivas. Quanto mais distantes estiverem maior será o comprimento e vice-versa. A frequência de onda é diretamente proporcional à velocidade de propagação e inversamente proporcional ao comprimento de onda.

A REM pode ser representada por diversas regiões de radiações presentes no espectro eletromagnético. Na verdade, esse espectro representa a distribuição da REM por regiões conforme seu comprimento de onda e frequência. Apresentamos detalhadamente esta distribuição através da FIGURA 9 no item da Cartografia Temática.

O espectro eletromagnético compreende desde as ondas maiores como as ondas de rádio de baixa frequência até as ondas menores como as dos Raios $X$ de alta frequência (FLORENZANO, 2002).

Existem ondas na região da faixa do visível localizadas entre o Infravermelho e o Ultravioleta (Ver FIGURA 9). Essa região é a única visível ao olho humano sendo ele capaz de distinguir cores o vermelho ao violeta. A região do Infravermelho é subdividida em: Próximo, Médio e Distante. Já a região do Ultravioleta é capaz de detectar vapor de mercúrio que escapa dos depósitos de minério localizados abaixo da superfície terrestre (MARCHETTI \& GARCIA, 1986). 
A REM após incidir na atmosfera, atravessando-a, atinge os objetos ou alvos na superfície terrestre e interage com os mesmos. Como resultado dessa interação, a energia incidente é fracionada em três componentes, ou seja; parte é absorvida, parte é transmitida e parte é refletida de volta para o espaço ou sensor/satélite (FIGURA 13). Além disso, os alvos também emitem a REM, resultante de reações físico-químicas que ocorrem ao nível atômico e molecular de cada alvo. Assim, é possível analisar as condições dos alvos na superfície terrestre com o emprego de sensores que captam a radiação refletida ou emitida pelos mesmos.

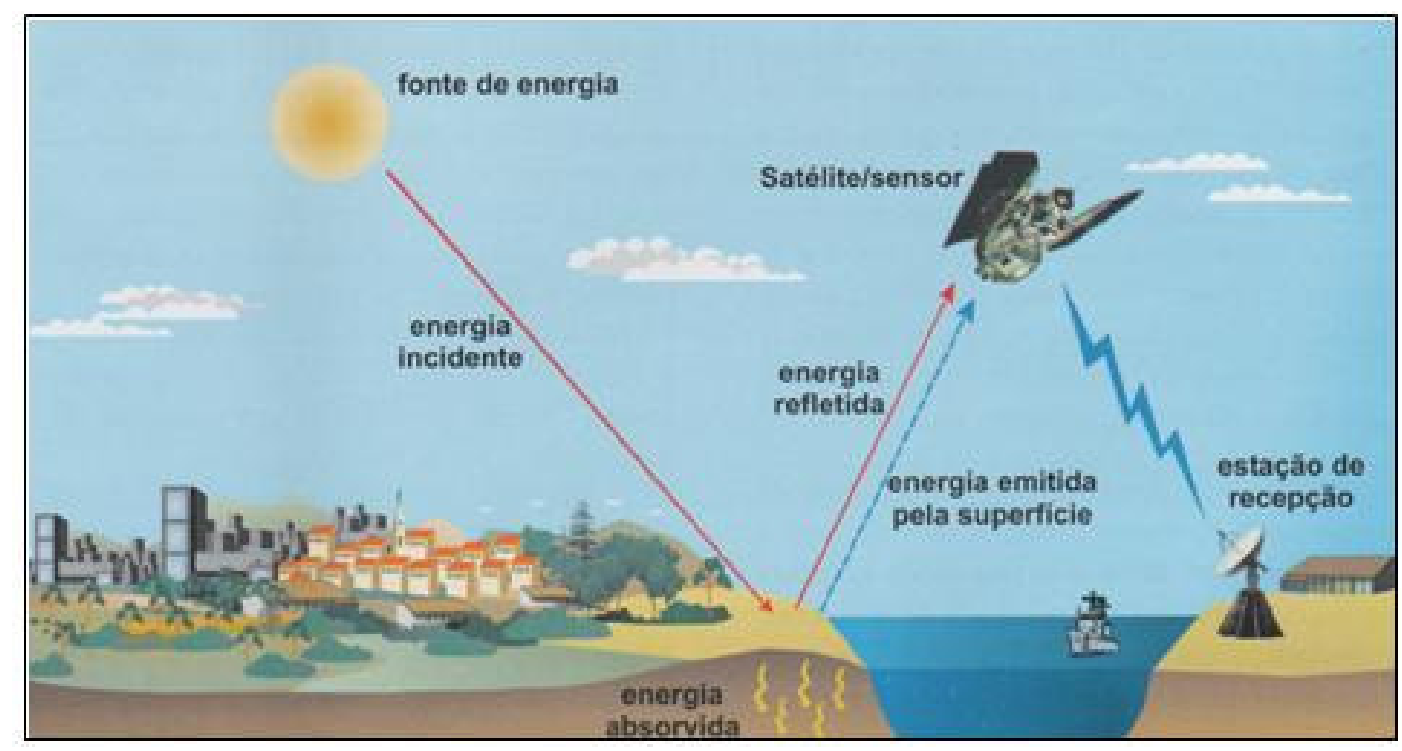

FIGURA 13 - Obtenção de imagens por SR.

FONTE: FLORENZANO (2002), p.9

Os estudos utilizando o SR favorecem algumas propriedades como a visão sinóptica, que permite a observação dos alvos de forma global incluindo áreas de difícil acesso.

Outra propriedade muito importante no SR são os tipos de resolução, como a Espectral, que possibilita o estudo e caracterização do comportamento espectral dos diferentes objetos encontrados na superfície; a Espacial, onde é determinada a menor distância entre dois objetos que o sensor é capaz de identificar como diferentes entre si; a Radiométrica, que define a sensibilidade do sensor, isto é, detecta a variação da energia (REM) em gradações de níveis de cinza; e finalmente a Temporal, referente à frequência na passagem do satélite sobre uma mesma área (SIMONETT, 1983).

O nível de aquisição dos dados em SR está inteiramente ligado à altitude do sensor. Dependendo da altitude haverá diferenças na dimensão da área detectada, na interferência dos fatores ambientais, na REM registrada pelo sensor, assim como no nível de informação.

Existem basicamente três níveis de coleta da REM por SR: Laboratório/Campo, Aeronave ou Orbital (NOVO, 1989). 


\section{1) NIVEL DE LABORATÓRIO/CAMPO:}

Podemos citar o uso dos espectroradiômetros que trabalham com a porção reduzida da matéria sem a interferência de fatores ambientais (FIGURA 14). Estes sensores de medição têm o intuito de determinar a curva ou assinatura espectral de um determinado alvo como, por exemplo: a vegetação, os solos, as culturas agrícolas e a água.

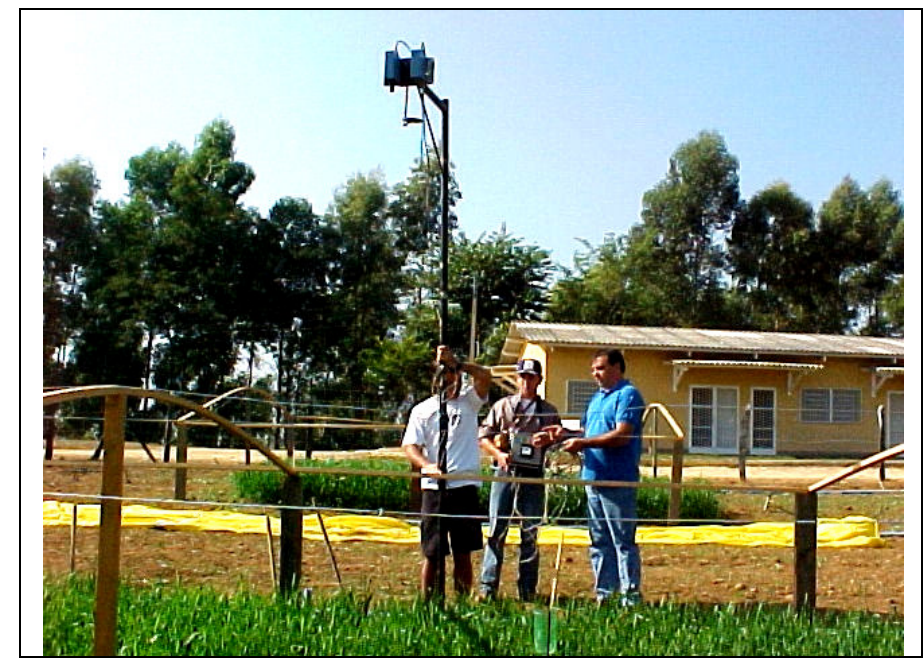

FIGURA 14 - Captura de dados no campo pelo espectroradiômetro.

FONTE: MOREIRA (2001), p. 118

As diversas formas de obtenção do comportamento espectral dos alvos permitem a realização da fotointerpretação destes para uma precisa e perfeita identificação do alvo detectado, o qual será parte integrante do levantamento para a confecção do mapa de uso e cobertura da terra.

a) Vegetação:

Para o estudo do comportamento espectral da vegetação é preciso considerar dois aspectos: primeiro das folhas como entidades independentes e segundo como um dossel. Ou seja, um conjunto de diferentes tipos de elementos da vegetação como: folhas, galhos, frutas, flores etc. (GOEL, 1988). As ocorrências de vegetação podem se dar em forma de: matas ou culturas e estão dispostas em uma mesma área de iguais (homogênea) ou diferentes (heterogênea) espécies.

As propriedades espectrais da vegetação podem ser representadas por processos de absortância, reflectância e transmitância, podendo cada uma ser hemisférica ou bidirecional (SLATER, 1980).

Mas, para representarmos estes processos temos que tomar como exemplo uma folha. E depois, transportar esse conhecimento em um conjunto delas como no caso de um 
dossel. Assim, a energia radiante incidente (I), ao interagir com a folha, é parcialmente absorvida $(A)$, transmitida $(T)$ e refletida $(R)$.

A energia absorvida seletivamente em determinados comprimentos de onda pelos pigmentos das plantas é, em parte, dissipada na forma de calor ou fluorescência, sendo que apenas uma pequena parcela da energia é armazenada em forma de compostos orgânicos através da fotossíntese (GATES et al., 1965).

De maneira geral, esse alvo se comporta com uma alta absorção da REM por parte dos pigmentos existentes nos cloroplastos na região do visível ( $V=0,45-0,70 \mu \mathrm{m})$. Eles são os responsáveis pela baixa reflectância da vegetação na faixa do visível (V). Esses pigmentos são a clorofila, os carotenos e as xantofilas presentes nas folhas em percentagens variadas (KUMAR, 1972).

Já na região do infravermelho próximo (IVP= 0,7-1,3 $\mu \mathrm{m})$, a energia radiante interage com a estrutura dos elementos presentes na vegetação, a reflectância espectral é geralmente constante e tem valores altos, e o espalhamento da REM é considerável. A absorção por parte da água é também muito baixa e tem pouca influência na sua reflectância.

A região do infravermelho médio (IVM=1,3-2,6 $\mu \mathrm{m}$ ) é dominada pela absortância das moléculas da água. E o infravermelho termal (IVT=3,0-20,0 $\mu \mathrm{m}$ ), a energia resulta fundamentalmente de vibrações moleculares devido à temperatura dos corpos. Assim, a radiação termal da vegetação depende da energia emitida, de sua emissividade e temperatura absoluta, encontrando-se intrinsecamente relacionada com o ambiente circundante, com a fisiologia foliar e com a disponibilidade hídrica.

Agora, a interação da REM com toda a cobertura vegetal (dossel) de uma região é bastante complexa devido aos próprios parâmetros que compõem a arquitetura do dossel, e o fato de ele ser geralmente composto por diferentes espécies vegetais. Pois, segundo GOEL (1988) já mencionado anteriormente, esse dossel tem os seguintes elementos da vegetação: folhas, galhos, frutas, flores etc.

O fluxo de radiação solar incidente sobre um dossel é constituído por duas partes: uma fração da radiação que não é nem absorvida e nem espalhada pela atmosfera, denominada fluxo direto, e outra fração espalhada pela atmosfera na direção descendente e que incide sobre o dossel de forma difusa, denominada de radiação difusa ou do céu.

Segundo GOEL (1988), o fluxo solar incidente sobre um dossel e sua radiância, ou seja, o fluxo que atinge o sensor depende não só das propriedades de absorção ou 
espalhamento dos elementos que compõem a vegetação, como também da orientação e densidade dos elementos.

O sensor recebe vários tipos de fluxos:

1. Fluxo espalhado por um elemento único da vegetação (espalhamento simples) num instante determinado de tempo;

2. Fluxo espalhado por diferentes elementos da vegetação em diferentes momentos de tempo (espalhamento múltiplo) que não atingiu o solo;

3. Fluxo refletido pelo solo que não é interceptado por outro elemento da vegetação, ou é interceptado e espalhado na direção do sensor.

A reflectância do dossel é produto da interação entre a radiação solar, a atmosfera, os elementos da vegetação e o solo. A análise da reflectância proveniente do dossel é muito complexa devido ao grande número de variáveis envolvidas (KUMAR, 1972; PINTER et al., 1985; GOEL, 1988; CURRAN \& WARDLEY, 1988).

Segundo COLWELL (1974), o fator de reflectância espectral bidirecional de folhas é o parâmetro fundamental para a caracterização do dossel. Outros parâmetros são: transmitância das folhas, quantidade e arranjo do dossel (galhos, frutos etc.), características do solo, ângulo zenital solar, ângulo de visada e ângulo azimutal relativo (da fonte e do sensor).

Para uma melhor compreensão da importância e influência de cada um destes parâmetros, no sinal que finalmente atinge o sensor, foram desenvolvidos diferentes modelos matemáticos baseados na interação da radiação com o dossel.

Existem, assim, numerosos modelos que descrevem esta interação como, por exemplo, os modelos de EGBERT (1977), JACKSON et al. (1979), OTTERMAN (1981 \& 1984), JUPP et al. (1986), entre outros proposto por VERHOEF e BUNNIK (1981) e também por GOEL (1988).

O modelo de reflectância do dossel fornece a conexão lógica das características botânicas e biofísicas do dossel, da geometria da interação radiométrica e das mudanças resultantes da radiação refletida (GOEL, 1988).

As folhas constituem o elemento dominante no processo de transferência de energia do dossel. Segundo KIMES e KIRCHNER (1983), a estrutura do dossel pode ser matematicamente descrita por diferentes parâmetros físicos como: a distribuição das plantas sobre o terreno, o Índice de Área Foliar (IAF), a densidade espacial das folhas e a distribuição da inclinação azimutal das folhas. 
Para o SR, a estrutura do dossel é de grande importância, pois descreve como é espalhada ou refletida a radiação por cada elemento (folha) individualmente.

b) Solos:

O comportamento espectral dos solos não é facilmente detectável pelos sistemas sensores dos satélites, pois juntamente com ele encontramos os usos que neles existem. Podendo ser de usos agrícolas, coberturas vegetais (florestas ou mangues), ocupações urbanas, indústrias entre outros.

Com o advento das fotografias aéreas iniciaram-se estudos quanto às informações sobre os solos, a saber: como a cor, o tipo de cobertura vegetal, uso agrícola, afloramentos rochosos, paisagem, padrões de drenagem que resultam em um melhor discernimento ou interpretação das características topográficas que o originaram ou como se constituem. Além de sua classificação, tipos de processos erosivos sofridos e inclusive sua umidade superficial.

Desta forma, os principais parâmetros que influenciam o comportamento espectral dos solos são os seguintes:

- Umidade: geralmente os solos se apresentam mais escuros quando úmidos do que quando secos. Ou seja, em tons de cinza escuros (solos úmidos) e tons claros (solos secos) na imagem.

Os solos úmidos têm uma coloração mais escura, pois a absorção da REM é maior devido à presença de água que apresenta uma diminuição da reflectância na região do visível (V) e do infravermelho próximo (IVP) do espectro eletromagnético, o que os difere completamente em relação aos solos secos.

Na região do infravermelho termal (IVT) a umidade é a maior responsável pelo comportamento do solo, ou seja, é inversamente proporcional à sua temperatura. Quanto maior o conteúdo de umidade, maior será sua inércia térmica, logo sua temperatura durante o dia será menor que a de um solo seco.

- Matéria orgânica: na medida em que o conteúdo esse parâmetro aumenta, a reflectância do solo diminui, no intervalo entre 0,4 e 2,5 $\mu \mathrm{m}$ (Visível ao Infravermelho Termal) (HOFFER \& JOHANNSEN, 1969).

Segundo PALÁCIOS-ORUETA e USTIN (1998) os altos teores de matéria orgânica estão relacionados com a estrutura e a capacidade de retenção de água no solo. O que pode originar uma redução da reflectância nas faixas de 0,7 a 0,75 $\mu \mathrm{m}$ (Visível) (CURRAN et 
al., 1990) e ainda produz interferências nas bandas que refletem o conteúdo de minerais como Manganês (Mn) e o Ferro (Fe).

Para CHUVIECO (1996) na região do Termal os solos com alto conteúdo de matéria orgânica se apresentam com valores menores de condutividade térmica e descrevem uma melhor diferença de temperatura entre dados coletados no período noturno ou diurno.

- Granulometria: o tamanho e a forma das partículas, bem como o tamanho e a forma dos agregados do solo (resultantes de uma trituração branda) parecem influir na reflectância do solo de várias maneiras.

A textura do solo influencia bastante suas propriedades óticas, ou seja, nos solos cuja rugosidade e o diâmetro das partículas são maiores, a luz incidida fica totalmente apreendida entre seus espaços livres, e assim ocorre uma relativa diminuição no retorno da radiação emitida e logo capturada pelo sensor.

Para STONER e BAUMGARDNER (1981) e VISCARRA-ROSSEL e MC BRATNEY (1998) as características de estrutura, textura e conteúdo de umidade do solo estão totalmente relacionadas entre si. Os solos de estrutura frágil com partículas grossas (areia) têm baixo conteúdo de umidade e de matéria orgânica, logo alta reflectância. Enquanto que os solos de partículas mais finas (argilosos) têm maior retenção de umidade e maior conteúdo de matéria orgânica, conseqüentemente irão ter baixa reflectância.

- Óxidos de Ferro: são muito importantes para solos tropicais altamente intemperizados. O tipo e a quantidade relativa de óxidos de ferro influenciam as cores dos solos, que variam de vermelhos a amarelos, os quais são ricos em argilas sesquioxídicas.

Os solos com elevado conteúdo de ferro poderiam ser facilmente distinguidos pela inflexão característica dada pelo $\mathrm{Fe}_{2} \mathrm{O}_{3}$ (FORMAGGIO, 1999).

O conteúdo de óxido de ferro livre no solo é bastante significativo (em termos de influência espectral) tanto no visível (V) quanto no infravermelho próximo (IVP). Porém, a significância aumenta com o aumento dos comprimentos de onda e a presença de $\mathrm{MO}$ não diminui a contribuição do ferro para a reflectância do solo (MONTGOMERY, 1979).

- Mineralogia de argila: nos espectros dos minerais de argila dos grupos Montmorilonita e Caulinita, as principais feições de absorção se devem à presença de água.

As bandas de absorção no Infravermelho Médio de 1,4 e 1,9 $\mu \mathrm{m}$ (absorção muito forte) ocorrem devido à presença de água molecular confinada, típica das Montmorilonitas. E no intervalo centrado no Infravermelho Médio em 1,4 e 2,2 $\mu$ m (absorção forte) são típicas da reflectância da Caulinita, enquanto que a falta de água confinada em quantidade apreciável resulta em somente uma banda de absorção em 1,9 $\mu \mathrm{m}$ (absorção fraca). 
Segundo PIZARRO et al. (2001) os solos de alto teor de argila apresentam valores altos de reflectância na faixa espectral do vermelho devido à concentração de óxido de ferro. Logo sua cor será mais escura do que normalmente são os solos, devido à reflectância ser menor na faixa do visível.

- Material de origem: as curvas de reflectância para solos desenvolvidos de calcários, de argilitos e de arenitos exibem formas características contrastantes.

As intensidades de reflectância das rochas ígneas diminuem a partir das formas ácidas, passando pelas intermediárias, pelas básicas e até as ultrabásicas, as quais sempre mostram uma banda de absorção bem definida de ferro-ferroso próximo de 1,0 $\mu \mathrm{m}$ (IVP).

c) Culturas Agrícolas:

O comportamento espectral das culturas agrícolas é bastante distinto devido às suas próprias propriedades específicas e também as suas condições físicas como: déficit hídrico, senescência, floração, estresse, doenças, ataque de pragas, tipo de manejo, etc. Ou ainda em relação a sua forma e tamanho das plantas, folhas, flores e frutos.

A geometria de uma planta pode determinar o tipo de estrutura do dossel e a quantidade maior ou menor de sombra criada, o que irá proporcionar uma coletânea de variabilidade e diversidade de tons, texturas e cores diferenciadas.

Assim, como existem diferenças sutis que não são detectáveis nos sinas de retorno ao sensor da energia emitida. Esse tipo de característica única identificada na região do vermelho $(\mathrm{V})$ e acaba proporcionando uma resposta semelhante à outra cultura que não é a que se está analisando ou a verdadeira. A resolução deste impasse acaba sendo a utilização de faixas na região do infravermelho próximo (IVP).

As culturas agrícolas apresentam uma baixa reflectância no período de plantio, pois como ainda são muito jovens e tem poucas folhas, o solo é que reflete mais REM do que a cultura. Esta condição é modificada quando a cultura atinge seu ápice no desenvolvimento e cobre todo o solo passando a ter uma alta reflectância.

Podemos também mencionar os tipos de manejo que influenciam bastante 0 comportamento espectral das culturas. Podemos analisar como exemplo a aplicação da técnica de plantio direto por anos em uma determinada cultura com a de plantio convencional em outra, onde as diferenças serão fatores decisivos. Pois, segundo MCMURTREY et al. (1993) no plantio direto a quantidade de resíduos das culturas é bastante significativa enquanto que o convencional é representado apenas pelas características espectrais do tipo de solo. 
Em experimentos de análises dos resíduos da cultura de milho, trigo e soja partidos estudado por estes autores se observaram que nas regiões do azul (A), vermelho (V) e infravermelho próximo (IVP) as respostas destes resíduos são maiores, logo solos mais escuros e em solos mais claros menores devido à resposta exclusivamente do solo nas épocas pós-colheita.

Segundo MOREIRA (2001) existe culturas que devido sua estrutura foliar não cobrem todo o solo e também têm sua forma de plantio com grande espaçamento como é o caso da cultura do café e citrus (laranja, limão, tangerina, etc.). Os quais se apresentam com seu comportamento espectral específico adicionada com a contribuição da reflectância do solo.

Já a cultura da cana-de-açúcar nas regiões do visível apresenta baixa reflectância devido à absorção da radiação incidente pelos pigmentos das folhas e em especial nas regiões do Azul (A) e Vermelho (V). No entanto, na região do Infravermelho Próximo (IVP) e Infravermelho Médio (IVM) essa reflectância é alta e vai gradativamente aumentando devido principalmente a quantidade de folhas que sofrem múltiplas reflexões da radiação incidente recebida nos espaços intracelulares do mesófilo foliar (RUDORFF \& BATISTA, 1985).

Os autores destacam que esse aumento no número de folhas ou aumento do Índice de Área Foliar (IAF) são fatores preponderantes na reflectância da planta na região do IV. E na cana o acúmulo de matéria seca (MS) tem um comportamento sigmodal, o qual se divide em três fases: crescimento lento (inicial), crescimento rápido (intermediária) possuindo cerca de 70 a $80 \%$ da MS total e final, onde o crescimento volta a ser lento para haja o acúmulo de sacarose nos colmos (EDGERTON, 1958; PARANHOS, 1987).

Na FIGURA 15 a imagem apresentada é do sensor TM do satélite Landsat 5 na composição R4G5B3, na qual observamos o comportamento espectral de áreas com plantio de cana (a), presença de cana cortada crua (b) e de queimadas para o corte (c).

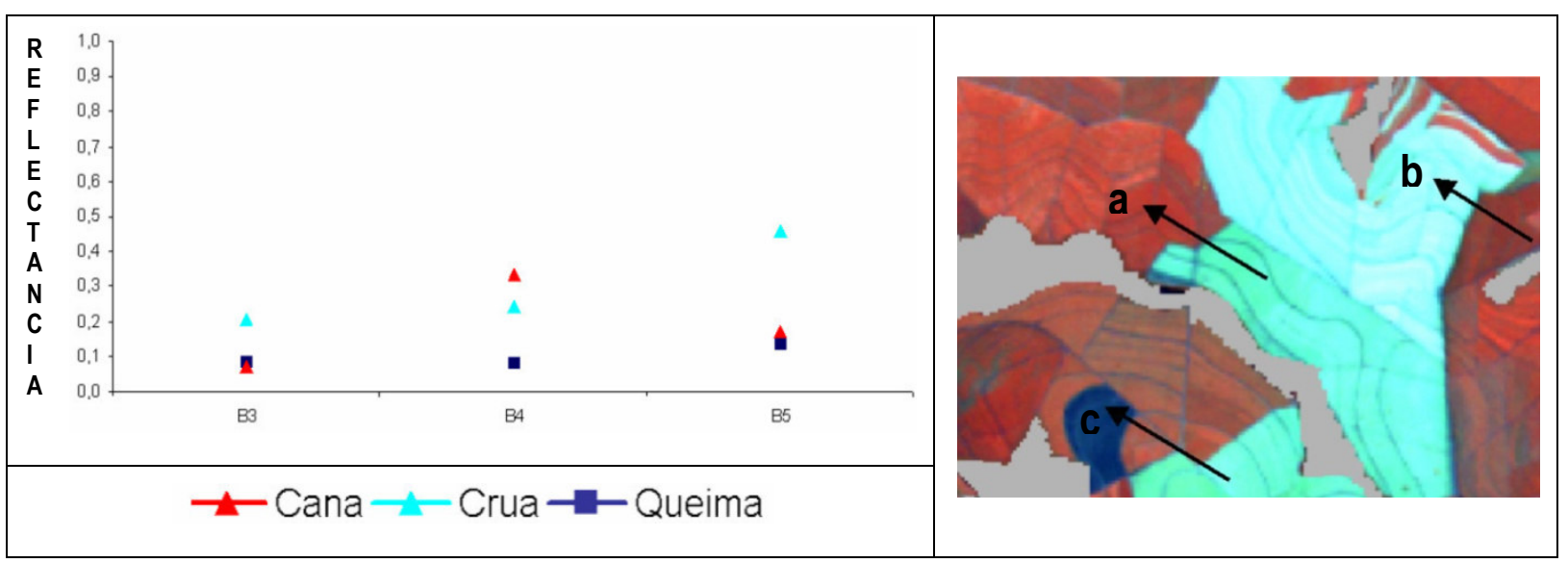

FIGURA 15 - Resposta espectral da cana-de-açúcar. 
FONTE: AGUIAR (2007), pg 19.

Na banda 3 a reflectância dessa cultura é baixa em decorrência da absorção da radiação incidente pelos pigmentos das folhas. Já no Infravermelho próximo ou banda 4 ela é alta e aumenta gradativamente da cana como aumento da quantidade de folhas em função das múltiplas reflexões da radiação incidente nos espaços intracelulares do mesófilo foliar.

Mas, na banda 5 a reflectância diminui em função da absorção pela água nas folhas. $\mathrm{E}$ as áreas de queimadas para o corte apresentam baixa reflectância em todas as bandas devida a presença da cinza decorrente da queima. Em contrapartida, as áreas de cana colhida têm alta reflectância pela presença de restos de culturas como as folhas secas, ou seja, decorrência da redução do teor de água do interior das células das folhas mortas (AGUIAR et al., 2007)

O déficit hídrico é outro fator que afeta muito o comportamento espectral das culturas. Podemos citar como exemplo a soja, onde segundo SHORT (2008), a REM é progressivamente diminuída na faixa do infravermelho próximo (IVP) e aumentada no infravermelho médio (IVM) evidenciando não somente a perda de água (estresse hídrico), mas também o desarranjo do tecido intercelular diminuindo assim a concentração de clorofila nas folhas.

Como exemplificação se apresenta na FIGURA 16, a resposta espectral das culturas de soja, milho e algodão na imagem do sensor ETM+ do satélite Landsat 7 na composição R4G5B3. Nota-se que a cultura de soja tem um alto nível digital na banda 4 (IVP) quase o dobro da cultura do milho (YI, 2005).

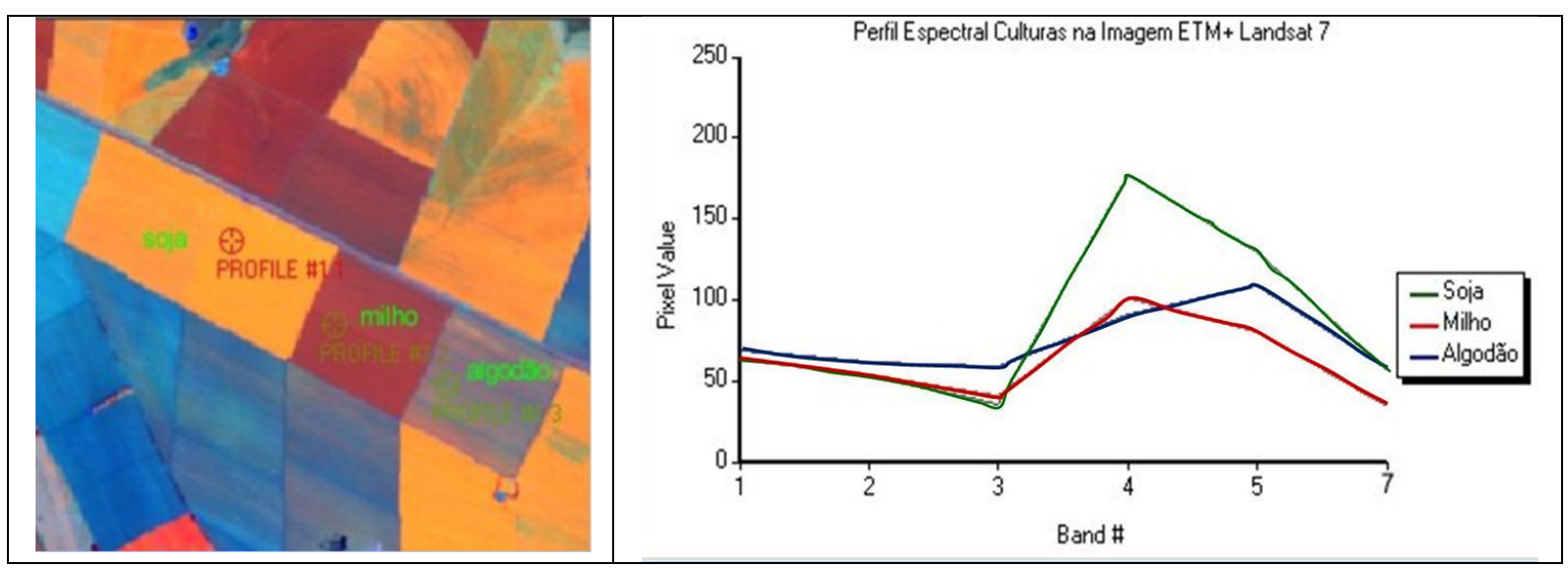

FIGURA 16 - Perfil espectral das culturas de soja, milho e algodão.

FONTE: YI (2005), p. 41

Segundo YI (2005) na cultura do algodão ainda existe bastante influência do solo devido essa cultura se encontrar em fase de desenvolvimento vegetativo (pré-floração), 
onde a mesma ainda está no inicio de fechamento do dossel. E o maior valor de resposta espectral dessa cultura está discriminado na banda 3 na faixa do vermelho (V).

No infravermelho vermelho próximo (banda 4) a cultura de algodão encontra-se com menor absorção da radiação devida simplesmente à sua grande atividade fotossintética. Em suma nesta banda os valores digitais são bem distintos entre si nas três culturas.

d) Água:

O comportamento espectral da água é caracterizado em seus diferentes estados físicos: líquido, gasoso (nuvens) ou ainda sólido (neve) (NOVO, 1989). E em cada um destes estados físicos a REM é absorvida de forma diferente uma da outra.

No estado líquido, a água apresenta uma baixa reflectância $(\mathrm{V}=0,38$ a 0,70 $\mu \mathrm{m})$, devido a sua alta absorção da REM em quase todas as faixas do espetro eletromagnético (MOREIRA, 2001).

A Água pode absorver ou pode refletir e ainda retro-espalhar toda a energia solar nela incidente devido principalmente às partículas existentes. Ou seja, a matéria orgânica ou inorgânica presente na água pode influenciar diretamente nesta absorção.

Quando a concentração de matéria orgânica encontrada na água aumenta consideravelmente ocorre um decréscimo na reflectância na faixa do visível (MANTOVANI, 1993). Já a presença de partículas inorgânicas (rochas e solos) influência no aumento da reflectância da água devido ao número de partículas (grânulos) nas faixas do vermelho ao infravermelho próximo (NOVO, 1989).

STEFFEN et al. (1992) mediram a reflectância da água em três pontos no estado de São Paulo: no reservatório de Barra Bonita (formado pelo Rio Piracicaba e Tietê), no Rio Tietê e no Rio Piracicaba.

Estes autores concluíram que o Rio Tietê se apresenta com reflectância típica de água com elevada concentração de material inorgânico em suspensão (alta reflectância no vermelho). Já no Rio Piracicaba a reflectância da água é baixa com pico no verde, o que pressupõem forte presença de material orgânico em suspensão. Enquanto que em Barra Bonita se visualiza claramente a transição das águas dos dois distintos rios (FIGURA 17). 


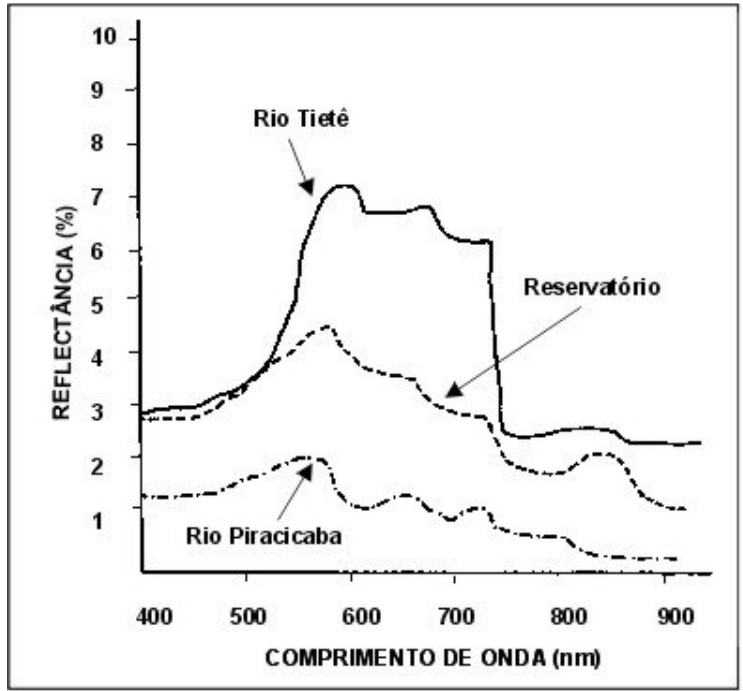

FIGURA 17 - Curvas de reflectância dos Rios Tietê, Piracicaba e Reservatório de Barra Bonita (SP). FONTE: Adaptada de STEFFEN et al. (1992).

A nuvem apresenta uma altíssima reflectância da faixa do Visível até o Infravermelho Termal (0,38 a 2,5 $\mu \mathrm{m})$, e a neve apresenta reflectância ainda maior que a nuvem (IVP=0,7 a $1,2 \mu \mathrm{m}$ e IVM=1,2 a $1,4 \mu \mathrm{m})$.

e) Sombras:

O comportamento espectral das sombras tanto topográfico como de nuvens se apresenta de forma linear com valores de ND (número digital) ou nível de cinza próximo a zero, não se obtendo informações devido à presença de pouquíssima radiação solar (CRÓSTA, 1992). No entanto para o estudo de formas de relevo e feições geológicas, as sombras topográficas são de grande utilidade para a análise das estruturas geológicas.

A pouca REM refletida das áreas sombreadas e representada em tons de cinza escuro podem ajudar como auxílio na separação de diferentes tipos de vegetação. Ou ainda ter um fator negativo devido à difícil identificação e delimitação dos limites dos talhões dos diferentes alvos de uso e ocupação do solo.

\section{2) NÍVEL DE AERONAVE:}

Este nível de coleta registra a REM de vários objetos, ou seja, de um arranjo deles na cena. Podemos tomar como exemplo a tomada de fotos por um avião a 1000 metros de altura, onde alvos pequenos como um automóvel em uma rua poderá ser visto pelo sensor.

\section{3) NÍVEL ORBITAL:}

Observamos que neste nível a REM registrada compreende a integração da resposta de diferentes objetos em cada elemento de resolução do terreno. Como por exemplo, as 
imagens de um satélite a uma altitude de $920 \mathrm{~km}$ da superfície terrestre que provavelmente representará em um único sinal a integração de diversos objetos de dimensões variáveis como: florestas, rios, cidades entre outros de cada porção do terreno.

Existe uma grande diversidade de imagens de satélite a nível Orbital, porém nos concentraremos apenas naquelas que estarão envolvidas neste trabalho de pesquisa como: imagens dos sensores MODIS do satélite TERRA, CCD do satélite CBERS, do Produto GEOCOVER e da Missão Topográfica por Radar Interferométrico (SRTM).

\section{Satélite TERRA:}

As imagens deste sensor serão utilizadas para realizar o mapeamento do uso e cobertura da terra devida sua melhor resolução e da aquisição diária de suas imagens.

Foram feitos diversos levantamentos bibliográficos que nos convenceram que este sensor é um dos mais aplicados ao uso e cobertura da terra conforme dados técnicos e específicos aqui descritos.

A abordagem sobre as imagens do sensor MODIS do Projeto EOS (Earth Observing System) será de forma mais sucinta e resumida possível. Pois, elegemos aqui apenas alguns dos parâmetros e características mais importantes para o entendimento de como serão identificadas as formas de uso e cobertura da terra.

O Satélite "TERRA", lançado em dezembro de 1999, possui a bordo cinco sensores: MODIS, MISR, ASTER, CERES e MOPITT. Os quais têm como finalidade promover observações globais e também o entendimento científico das seguintes prioridades (NASA, 2008):

1. Mudanças na cobertura da terra e produtividade global, incluindo tendências e modelos em escala regional, biodiversidade e produtividade primária global;

2. Predição de clima sazonal e interanual com objetivo de melhorar os cálculos do tempo e da extensão geográfica de anomalias climáticas;

3. Perigos naturais incluindo a caracterização de desastres e redução de riscos como: queimadas, vulcanismos, inundações e estiagens;

4. Estudo da variabilidade climática em longo prazo com intuito de ajudar os cientistas a identificar os mecanismos e fatores que determinam as variações climáticas, incluindo os impactos das alterações humanas;

5. Estudo do ozônio atmosférico para auxiliar os cientistas a detectar mudanças com suas causas e conseqüências. 
Em maio de 2002, o Programa EOS lançou um segundo Satélite chamado de "ACQUA" com horário de passagem às 13h30min (PM) e carregando à bordo os sensores: MODIS, AMSU, HBS, AMSR-E e CERES.

O principal sensor do Programa EOS é o MODIS (Moderate Resolution Imaging Spectroradiometer), o qual possui 36 bandas espectrais e resolução radiométrica de 12 bits.

Segundo BARKER et al. (1992) o MODIS apresenta inúmeras características e por isso é considerado um dos sensores mais importantes do Programa EOS. Podemos apontar as principais, entre elas:

a) Ampla cobertura espacial e espectral;

b) Continuidade nas tomadas de medidas nas regiões espectrais que vem a complementar as estimadas por outros satélites. Como no caso dos dados do Satélite NOAA/AVHRR usado na meteorologia e monitoramento da temperatura da superfície do mar, gelo e vegetação, e do Coastal Zone Color Scanne (CZSC) utilizado para monitorar a biomassa oceânica e os seus padrões de circulação;

c) É o principal sensor dos satélites do Programa EOS para o direcionamento de pesquisas das mudanças globais.

O Satélite "TERRA" é conhecido como o EOS-AM e o "ACQUA" como EOS-PM por capturarem imagens da superfície da terra nos horário da amanhã e tarde, respectivamente. E os mesmos foram construídos e projetados com o intuito de promoverem diversos estudos em três áreas distintas e interligadas entre si: na atmosfera, no oceano e na terra.

O sensor MODIS é superior quando comparado a outros sensores de SR em relação a intervalos de revisita. Podemos analisar esta informação na TABELA 6.

TABELA 6 - Intervalos de revisita de alguns satélites de SR.

\begin{tabular}{c|c|c|c}
\hline \hline SATÉLITE & SENSOR & $\begin{array}{c}\text { INTERVALO DE REVISITA } \\
\text { (dia) }\end{array}$ & $\begin{array}{c}\text { PASSAGEM NO EQUADOR } \\
\text { (hora) }\end{array}$ \\
\hline Landsat 5 e 7 & TM e ETM $^{+}$ & 16 & $09: 45$ e 10:00 \\
\hline SPOT & HRV e Vegetation & 26 (Nadir) e 4 a 5 (Orientado) & $10: 30$ \\
\hline TERRA / ACQUA & MODIS & 2 & $10: 30$ e 13:30 \\
\hline TERRA & ASTER & 16 & $10: 30$ \\
\hline \hline
\end{tabular}


FONTE: Adaptado de SCHOWENGERDT (1997).

Segundo BARKER et al.(1992) o posicionamento das bandas do sensor MODIS no espectroeletromagnético são direcionadas para as aplicações terrestres, observações oceânicas e para as medições atmosféricas. E também para a cobertura da terra na porção termal favorecendo a sua utilização por diversos campos das ciências naturais (TABELA 7).

TABELA 7 - No. de bandas e resolução espectral do Sensor MODIS.

\begin{tabular}{c|c|c|c}
\hline \hline APLICAÇÃO & BANDAS & BANDAS & $\begin{array}{c}\text { RESOLUÇÃO } \\
\text { ESPACIAL (m) }\end{array}$ \\
\hline Superfície Terrestre/Nuvem & 1 e 2 & $\begin{array}{c}\text { Vermelho e } \\
\text { Infravermelho Próximo }\end{array}$ & 250 \\
\hline Propriedades da Superfície/Nuvem & 3 á 7 & $\begin{array}{c}\text { Azul, Verde e } \\
\text { Infravermelho Médio }\end{array}$ & 500 \\
\hline Cor dos Oceanos/ Fitoplâncton/Bioquímica & 8 á 16 & $\begin{array}{c}\text { Azul, Verde, Vermelho e } \\
\text { Infravermelho Próximo }\end{array}$ & 1000 \\
\hline Vapor d'água Atmosférico & 17 á 19 & Infravermelho Próximo & 1000 \\
\hline \hline
\end{tabular}

FONTE: Adaptado de BARKER et al. (1992, p. 3-4) e LILLESAND e KIEFER (1994, p. 516).

Já as bandas de 20 a 36 restantes estão localizadas no Infravermelho médio, distante e no Termal com resolução espacial de 1000 metros. Onde, na maioria utilizam-se para estudo de altitude de topo de nuvens, temperatura atmosférica, cirrus, vapor d água, ozônio entre outros (BARKER et al.,1992 e LILLESAND \& KIEFER, 1994).

O MODIS é um sensor diferenciando dentre tantos devido exclusivamente ao seu alto desempenho em rastrear um amplo conjunto de sinais vitais da Terra. Segundo KING et al.(1992) este sensor tem capacidade de medir o percentual da superfície do planeta coberto por nuvens quase que diariamente.

Este sensor tem uma alta sensibilidade radiométrica desempenhando assim uma excelente resposta para cada banda, o que vem a suprir as necessidades da comunidade científica (STRAHLER et al., 1996). O que antes não era viabilizado por nenhum outro sensor anterior ao MODIS.

As bandas do Sensor MODIS de estudo da Superfície Terrestre são importantes, pois possibilitam uma perfeita detecção dos alvos ou objetos desde que haja certa habilidade na discriminação dos processos de mudanças do uso e cobertura da terra. Pois, as mudanças ocorrem baseadas por distúrbios naturais ou de origem humana (antrópica).

Porém, algumas das mudanças no uso e cobertura da terra relacionada especificamente por alterações antrópicas não são detectáveis facilmente em bandas de resolução espacial maiores que 250 metros no Sensor MODIS. Para TOWNSHEND e JUSTICE (1998) apenas as alterações antrópicas que se aproximam a uma escala próxima 
a resolução de 250 metros, o são. Ou seja, para se ter uma perfeita identificação das mudanças no uso influência antrópica se aconselha a utilização de bandas no visível e no infravermelho próximo (as quais apresentam resolução de 250 metros).

Esta resolução tem sido amplamente utilizada na detecção de conversão da cobertura vegetal por ações antrópicas ou por desmatamento de florestas sob a influência de processos naturais como queimadas e inundações (ANDERSON et al., 2003).

O levantamento ou monitoramento dos tipos de uso e cobertura da terra por determinado sensor ou satélite dependerá única e exclusivamente do tamanho da área, e de quais alvos ou objetos pretende-se delimitar (escala). Para se ter noção de algumas resoluções espaciais atualmente utilizadas pela comunidade científica, veja a TABELA 8.

TABELA 8 - Relação da escala cartográfica versus resolução espacial.

\begin{tabular}{c|c|c}
\hline \hline ESCALA CARTOGRÁFICA & $\begin{array}{c}\text { RESOLUÇÃO } \\
\text { ESPACIAL(m) }\end{array}$ & SATÉLITE/SENSOR \\
\hline $1: 1.500 .000$ & 1.000 & TERRA/MODIS, NOAA/AVHRR \\
\hline $1: 500.000$ & 500,250 & TERRA/MODIS, ENVISAT \\
\hline $1: 100.000$ & 50 & SPOT 4/VEGETATION \\
\hline $1: 80.000$ & 30 & LANDSAT/TM \\
\hline $1: 50.000$ & 20 & LANDSAT/ETM, SPOT/HRV \\
\hline $1: 25.000$ & 10 & LANDSAT/ETM, SPOT/HRV, ASTER \\
\hline $1: 12.000$ & 5 & SPOT 5 \\
\hline $1: 5.000$ & 2,5 & IKONOS \\
\hline $1: 2.000$ & 0,60 & QUICKBIRD \\
\hline $1: 1.000$ & 0,40 & WORLD VIEW, AEROFOTOGRAMETRIA \\
\hline $1: 500$ & 0,20 & AEROFOTOGRAMETRIA \\
\hline \hline
\end{tabular}

FONTE: Adaptado de http://www.maplanbrasil.com.br/frames/faq frame.htm (2008).

Os detectores do sensor MODIS são distribuídos em quatro faixas de comprimento de onda (Visível, Infravermelho Termal, Médio e Próximo) na direção de vôo para se obter a mesma localização da Terra (tomadas do mesmo alvo) nas diferentes bandas e horários. (WOLFE et al., 2002).

O tamanho de cada cena obtida pelo sensor MODIS da superfície terrestre é definida como um "Tile" (quadrado). E corresponde a menor unidade de processamento referente aos níveis 2G, 3 e 4, é uma área geocodificada (cena) de 1200 x 1200 km (FIGURA 18). 


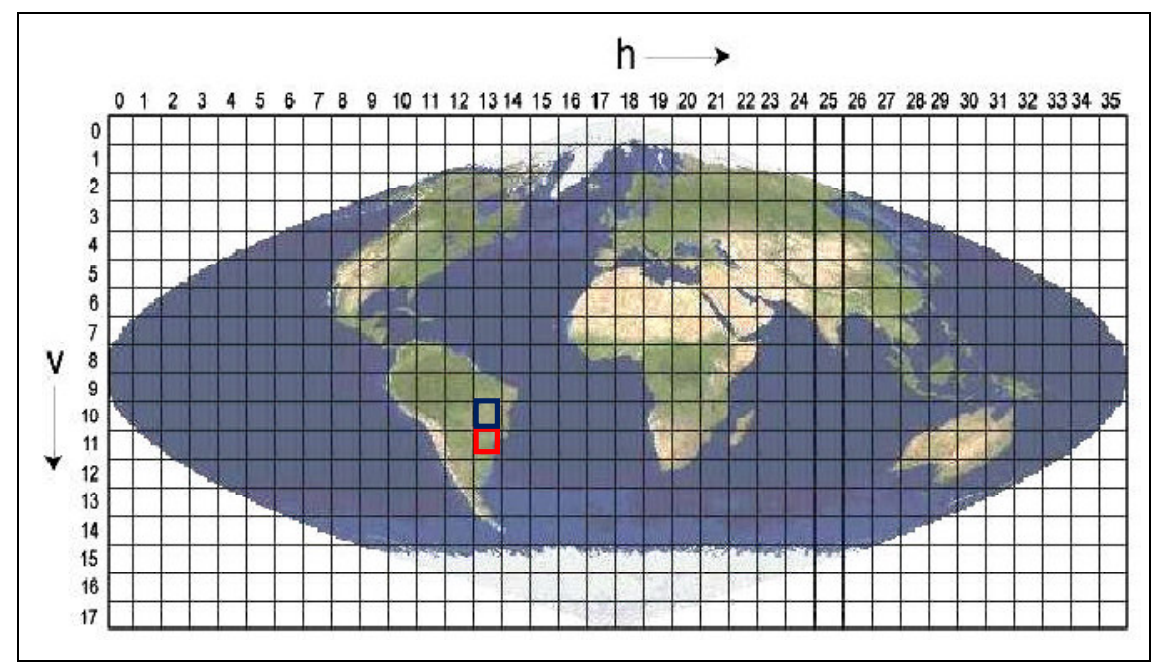

Figura 18 - Tiles MODIS h13v10 e h13v11 que cobrem o estado de São Paulo.

FONTE: NASA (2008).

A FIGURA 19 mostra o mosaico (composição) de 16 dias de imagens diárias (27 Jul a 11 Ago/2009) do sensor MODIS (MOD 13) do satélite TERRA do estado de São Paulo. As imagens se encontram em duas diferentes composições coloridas (RGB), a primeira R2G3B1; e a segunda R3G2B1. Onde, a banda 1 pertence a região do Azul, a 2 a região do Vermelho (Visível); e a 3 à região do IVP (Infravermelho Próximo) respectivamente.

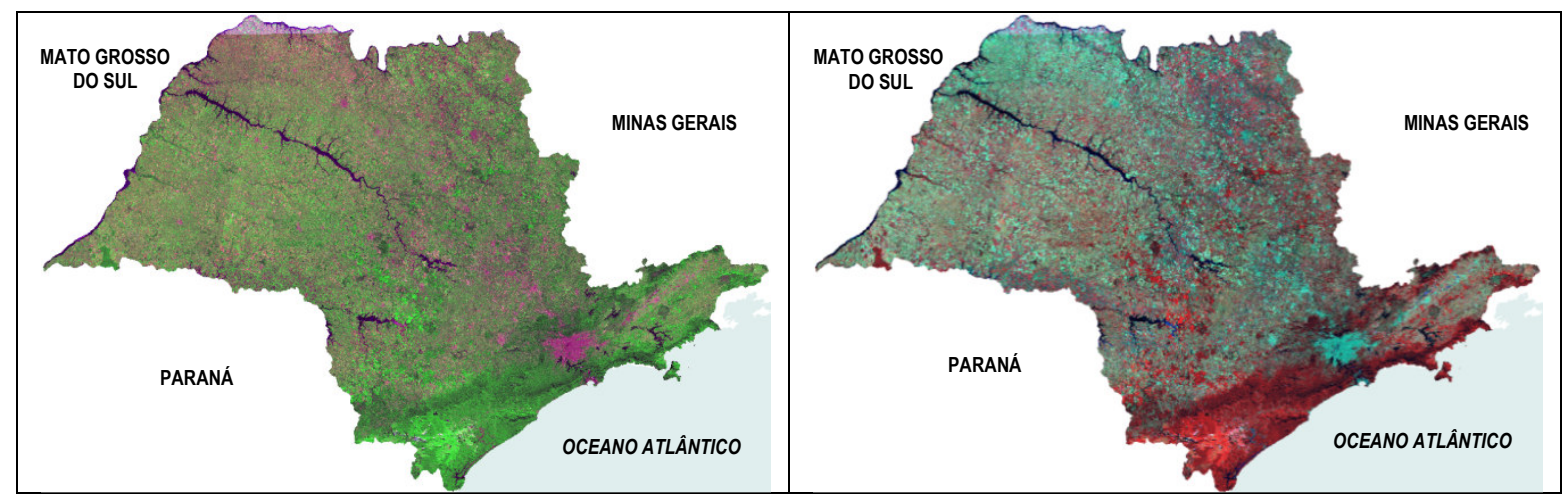

Figura 19 - Mosaico de imagens MODIS (MOD13) do estado de São Paulo.

FONTE: NASA (2009).

A garantia de qualidade (Quality Assurance) dos dados do MODIS é controlada pela EOS Data Information System (EOSDIS). Todo o suporte computacional relacionado ao processamento, distribuição e arquivamento de dados, assim como o intercâmbio de informações e resultados entre as comunidades científicas (JUSTICE et al., 2002).

Os produtos do sensor MODIS são úteis para a quantificação e detecção das mudanças da cobertura terrestre incluindo os processos naturais e antrópicos (humanos) em diversos modelos regionais e globais existentes (STRAHLER et al.,1999). 
Existem 44 produtos MODIS divididos em cinco categorias de aplicação: Calibração, Atmosfera, Continente, Criosfera e Oceano para o desenvolvimento de pesquisas em diversas disciplinas como: Geografia, Cartografia, Agronomia, Oceanografia, Biologia, etc.

No entanto, iremos nos centrar nos produtos MODLAND derivados da categoria Continente. Os quais estão subdivididos em três áreas de estudo: Balanço energético, Vegetação e Cobertura da terra.

Para o Balanço Energético existem seis produtos MODIS, a saber: MOD09, MOD10, MOD11, MOD29 e MOD43.

$\mathrm{Na}$ TABELA 9 estão dispostos os produtos MODIS gerados para o estudo da vegetação e da cobertura da terra, com suas respectivas aplicações e resoluções (espacial e temporal) acerca da área continental da Terra.

TABELA 9 - Alguns produtos da área continental do MODIS.

\begin{tabular}{|c|c|c|c|c|}
\hline \multirow{2}{*}{ ESTUDO } & \multirow{2}{*}{ CÓDIGO } & \multirow{2}{*}{ NOME POR EXTENSO } & \multicolumn{2}{|c|}{ RESOLUÇÃO } \\
\hline & & & TEMPORAL & ESPACIAL \\
\hline \multirow{3}{*}{ VEGETAÇÃO } & MOD13 & $\begin{array}{l}\text { MODIS/Terra Vegetation Indices L3 Global } \\
\text { ISIN Grid }\end{array}$ & 16 Dias & $\begin{array}{l}250 m \\
500 m\end{array}$ \\
\hline & MOD15 & $\begin{array}{l}\text { MODIS/Terra Leaf Area Index/FPAR L4 } \\
\text { Global ISIN Grid }\end{array}$ & \multirow{2}{*}{8 Dias } & \multirow{2}{*}{$1 \mathrm{Km}$} \\
\hline & MOD17 & $\begin{array}{l}\text { MODIS/Terra Net Photostnthesis L4 Global } \\
\text { ISIN Grid }\end{array}$ & & \\
\hline \multirow{3}{*}{$\begin{array}{l}\text { COBERTURA } \\
\text { DA TERRA }\end{array}$} & MOD12 & $\begin{array}{l}\text { MODIS/Terra Land Cover Type L3 Global } \\
\text { ISIN Grid }\end{array}$ & 96 Dias & \multirow{2}{*}{$1 \mathrm{~km}$} \\
\hline & MOD14 & $\begin{array}{l}\text { MODIS/Terra Thermal Anomalies/Fire Daily } \\
\text { L2 Swarh } 1 \mathrm{~km}\end{array}$ & $5 \mathrm{Min}$ & \\
\hline & MOD44 & $\begin{array}{l}\text { MODIS/Terra Vegetation Cover Conversion } \\
\text { L4 Global SIN Grid }\end{array}$ & 32 Dias & $250 \mathrm{~m}$ \\
\hline
\end{tabular}

FONTE: Adaptado de ROY et al.(2002, p.64).

O produto relacionado à vegetação, o MOD13 (Índices de Vegetação) foi o adquirido para o desenvolvimento deste trabalho de pesquisa na resolução espacial de 250 metros pela NASA (2009).

Este produto se apresenta de forma a comparar a partir de dados consistente os dados temporais e espaciais sobre as condições da vegetação global, fazendo a monitoração da atividade fotossintética da vegetação para averiguar a detecção de mudanças e também nas interpretações biofísicas e fenológicas.

Segundo HUETE et al. (2002) o produto MOD13 possui dois índices de vegetação, o NDVI (Normalized Difference Vegetation Index ou Índice da Diferença Normalizada) e EVI 
(Enhanced Vegetation Index ou Índice de Vegetação Melhorado), os quais produzem globalmente imagens com $1 \mathrm{~km}, 500 \mathrm{~m}$ e $250 \mathrm{~m}$ de resolução espacial nas composições com período de 16 dias.

Os autores esclarecem que o NDVI é sensível à clorofila, porém o EVI é às variações na resposta estrutural do dossel incluindo o índice de área foliar ( $\mathrm{LAI}$ ), a fisionomia da planta e também a arquitetura do dossel. E estes dois índices são importantes e complementares para os estudos globais de vegetação, pois fornecem informações mais precisas sobre a detecção de mudanças vegetais, assim como dos parâmetros biofísicos do dossel.

Os produtos MOD15 e MOD17 são indicados nos estudos para gerar a estimativa de rendimento de colheita, produtividade de florestas e alguns produtos relacionados intimamente ao crescimento da vegetação (NASA, 2008).

Agora, os produtos MOD12, MOD14 e MOD44 relacionados à cobertura da terra são utilizados para a construção de mapas globais e regionais no auxilio de pesquisas na superfície terrestre como, por exemplo, a modelagem de ecossistemas ou monitoramento de queimadas.

\section{Satélite $\underline{C B E R S}$ :}

Para executarmos o mapeamento do uso e cobertura da terra do estado de São Paulo utilizaremos o mosaico de imagens do satélite CBERS para averiguaremos dúvidas de fotointerpretação. O mosaico CBERS na resolução espacial de 90 metros (reamostrados) pertence ao Projeto CANASAT (RUDORFF et al., 2009).

A utilização das imagens CBERS proporcionará uma melhor visualização dos tipos de uso que representaram dúvidas durante a fotointerpretação. A escolha destas imagens se deve pela sua alta resolução espacial.

Ficou resolvido de não usar as imagens do CBERS em contrapartida das imagens do MODIS (Moderate Resolution Imaging Spectroradiometer) simplesmente porque as imagens do satélite CBERS ainda se encontram em adequação e controle de dados (correções de geodésia e posicionamento). Sem mencionar no grande número de imagens (faixa de cobertura de $113 \times 113 \mathrm{~km}$ ) que seriam necessárias para a cobertura total do estado de São Paulo em escala pequena.

Diversos pesquisadores vêm trabalhando e testando estes produtos (imagens) deste satélite. Porém, um dos erros mais comuns está relacionado ao posicionamento geodésico, o qual foi em parte resolvido pelo produto GEOCOVER. 
Desta forma, para que possamos usufruir e extrair alguns dados provenientes das imagens do satélite CBERS necessitamos compreender e saber das funcionalidades, características e principalmente dos tipos de produtos oferecidos.

A cooperação científica e tecnológica espacial entre o Brasil e a China resultou na criação do Programa CBERS (China Brazil Earth Resources Satellite Sino-Brasileiro de Recursos Terrestres).

Nos satélites CBERS-1 e 2 existem três sensores à saber: uma câmara CCD (Couple Charged Device), o IR-MSS (InfraRed MultiSpectral Scanner) e o WFI (Wide Field Imager). Existe ainda um sistema de coleta de dados ambientais que retransmite dados em tempo real para pequenas estações autônomas terrestres.

Destes, a câmara CCD é o sensor que nos interessa. Ela cobre uma faixa de $113 \mathrm{x}$ 113 km com resolução de 20 metros nos canais multiespectrais e de 10 metros na pancromática. O CCD possui uma capacidade adicional de apontamento lateral de mais ou menos $32^{\circ}$ aumentando a freqüência de observação ou visão estereoscópica para uma determinada área.

A faixa de cobertura dos sensores de qualquer satélite nos permite determinar quantas imagens necessitaremos para cobrir a área de interesse. E, além disso, permiti dimensionar em que melhor escala se poderá desenvolver nossa pesquisa.

A coleta de dados da câmara CCD varia de 26 dias (CBERS, 2008).

A periodicidade também é importante para a identificação das mudanças ocorridas no espaço geográfico. Facilitando o estudo e o monitoramento dos fenômenos naturais ou humanos ocorridos na região.

No próximo ano está previsto o lançamento CBERS 4 e segundo INPE (2008) a série destes satélites trouxe a comunidade científica e acadêmica avanços significativos ao Brasil. O que estamos falando é de cerca de 15.000 usuários de 1.500 instituições que vêm utilizando estas imagens para diversos estudos.

\section{Produto GEOCOVER:}

Este produto será abordado neste trabalho de pesquisa devido às correções de posicionamento geodésico realizada nas imagens do CBERS. Além disso, o mesmo ainda 
também pode nos dá suporte quanto aferição de dúvidas de fotointerpretação durante a edição do mapa de uso e cobertura da terra do estado de São Paulo.

Queremos destacar que todos os dados de imagens e vetoriais terão que estar devidamente georreferenciados, pois do contrário não poderemos obter nenhum cálculo de medida ou distância entre outros necessários para o desenvolvimento e conclusão deste trabalho de pesquisa.

O Produto GEOCOVER é uma coleção de imagens do satélite Landsat de alta resolução ortorretificadas que cobre toda a superfície terrestre do mundo com exceção da Antártida. Com este produto podemos estudar e desenvolver pesquisas de Uso e Cobertura do Solo para diversas áreas como: avaliação ambiental, planejamento, gestão de terras, recursos naturais e muitas outras das ciências da Terra (LANDCOVER, 2008).

O primeiro Produto GEOCOVER é um Mosaico de composição R5G4B2 com imagens ortorretificadas do satélite Landsat 5 na projeção Universal Transverse Mercator (UTM)/World Geodetic System 1984 (WGS84) com tamanho de pixel de 28,5 e 30 metros de resolução espacial. Outro Mosaico ortorretificado é do satélite Landsat 7 sensor $\mathrm{ETM}^{+}$ resolução espacial de 14,25 metros.

A USGS (United States Geological Survey) utilizou cerca de 8500 cenas do Landsat 7 para criar o mosaico de toda a superfície terrestre. Este mosaico originou a construção dos mapas de base do Google EARTH. E hoje o mesmo é muito utilizado em pesquisas acadêmicas, privadas e do governo, como o INPE que as utiliza para o georreferenciamento de imagens do satélite Landsat e também do CBERS. No caso do CBERS trata-se da aquisição de imagens ainda com alguns acertos de geodésia e posicionamento.

\section{Missão Topográfica por Radar Interferométrico ( $\underline{\text { SRTM}})$ :}

O Objetivo principal da descrição dos dados coletados pelo Ônibus Espacial Endeavour (Space Shuttle Endeavour) é a construção a partir de grades de MNT (Modelo Numérico do Terreno) das curvas de nível e, por conseguinte do mapa de Relevo e a declividade da área de estudo. Com o intuito de identificar as áreas de difícil acesso como as serras entre outros, as quais ainda se preservam e conservam regiões com remanescentes florestais.

Deve-se lembrar que esses dados não apresentam registros da planimetria como os rios, lagos, litoral, etc. A resposta é bem simples em quanto tempo poderemos conseguir os dados de curvas de nível de uma área pela digitalização ou compilação destes dados??

Em se tratando de uma área territorial de $248.209,426 \mathrm{~km}^{2}$, a do estado de São Paulo, seria necessária a contratação de pessoas treinadas para digitalizar em uma escala 
1: 500.000 a quantia de 11 cartas topográficas. Isso sem mencionar que em algumas cartas existem erros grosseiros de digitalização, onde uma carta não coincide com outra.

Com o exposto acima temos convicção que os dados do SRTM se tornaram o melhor dispositivo encontrado nos dias de hoje para facilitar a compilação de curvas de nível de grandes áreas.

Desta forma, os dados do SRTM nos fornecerão informações a respeito das características topográficas e da altitude das estruturas geológicas da área de estudo com o intuito de melhorar a qualidade da fotointerpretação.

Segundo, o serviço militar (DSG) que confecciona os levantamentos topográficos do Brasil, bem como, depois da restituição e reambulação, os layers ou fotolitos das cartas topográficas será muito difícil no futuro a utilização de outro dado tão completo e rápido que represente e possibilite a elaboração do relevo da superfície terrestre.

O Projeto SRTM é pioneiro na utilização da interferometria a bordo do Ônibus Espacial Endeavour (Space Shuttle Endeavour) e encontra-se a uma altura de vôo de 233 $\mathrm{km}$ com uma inclinação de 57‥ Neste Ônibus (FIGURA 20) existe um conjunto de duas antenas que permitem a avaliação do perfil de altitude para a criação do modelo digital tridimensional da Terra entre as latitudes $60^{\circ} \mathrm{N}$ e $58^{\circ} \mathrm{S}$ (VALERIANO, 2004).

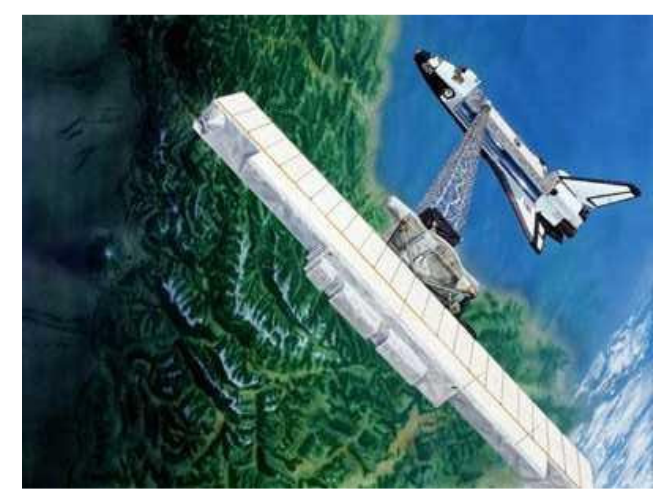

FIGURA 20 - Esquema de aquisição dos dados SRTM.

FONTE: ESTEIO (2005).

Esse tipo de interferometria é uma técnica de imageamento ativa, onde o radar emite o sinal por uma antena central e registra as características de retorno deste. Assim, esse retorno é capturado por duas outras antenas que ficam alocadas a certa distância uma da outra, as quais são comparadas entre si gerando o MDE (MELGAÇO et al., 2005).

A Missão Topográfica por Radar Interferométrico foi realizada no período de 11 a 22 de fevereiro de 2000, a qual coletou cerca de 12,4 Terabytes de dados brutos sobre a topografia de $80 \%$ das áreas emersas do planeta (FILHO, 2004). 
Os dados do SRTM são disponibilizados gratuitamente pela United States Geological Survey (USGS, 2008) com resolução espacial de 92,72 metros (http://seamless.usgs.gov). Mas, na verdade a grade retangular original do SRTM da América do Sul encontra-se com resolução de 30 metros, até hoje nenhuma informação foi fornecida quanto à redução da densidade de pontos dessa grade para 92,72913 metros (NÓBREGA et al, 2005).

De acordo com informações do Centro Aeroespacial Alemão (http://www.dlr.de/SRTM) as imagens com a resolução de 30 metros estão sendo comercializadas. Porém, os pesquisadores do INPE (INPE, 2000) asseguram que estes dados comercializados não são os mesmos fornecidos pela United States Geological Survey (USGS, 2008).

\section{A evolução histórica das aplicações do SR}

A evolução histórica das aplicações do SR vem a partir do uso das fotografias aéreas que eram comumente sobrepostas e utilizadas na confecção de mapas topográficos planialtimétricos, resultando ainda em imagens tridimensionais com apoio de estereoscópicos. Mas, existem muitos parâmetros a ser considerada para se relatar toda essa era cronológica. Neste sentido faremos uma rápida abordagem tendo em vista o foco principal deste trabalho de pesquisa.

Segundo MARCHETTI e GARCIA (1986), essas fotografias coloridas ou em infravermelho eram usadas para o mapeamento de solos e florestas, inventários de culturas e exploração geológica.

Já as fotografias de altas altitudes como as de satélite possibilitavam a análise de leves padrões de tonalidade na água do oceano, o que trazia o entendimento sobre as correntes marítimas e como os nutrientes eram trazidos para alimentar a fauna da região.

As imagens termais providas dos satélites eram outros produtos importantes no auxílio do combate ao fogo devido à identificação de focos de incêndios na floresta, em pilhas de carvão ou em veios subterrâneos de carvão. Ou em áreas de ocorrência natural de atividade térmica como vulcões (MARCHETTI \& GARCIA, 1986).

As imagens de Radar também proporcionaram grandes auxílios para estratégias militares. E um dos exemplos mais importantes históricos destas imagens é o Projeto RADAMBRASIL iniciado na Amazônia no levantamento e reconhecimento dos recursos naturais.

Os dados SR atrelados com o uso dos Sistemas de Informação Geográficas (SIG), os quais permitem a integração e transformação de dados espaciais com o favorecimento do alcance da precisão e generalização cartográfica. Tornaram-se sem dúvida uma grande 
união para a constituição da realidade da variabilidade de escalas e resoluções observadas nos produtos adquiridos ao longo do processo histórico.

Portanto, a evolução da tecnologia espacial vem a acrescentar um grande ícone para análise, levantamento e acompanhamento da evolução histórica de transformações e impactos observados desde a elaboração dos mapas antigos até os dias de hoje com surgimento das imagens orbitais de alta resolução espacial no planeta Terra.

Abaixo temos a TABELA 10 mostrando os principais estudos por áreas de atuação que podemos desenvolver com o uso desta tecnologia espacial:

TABELA 10 - Estudos por áreas de atuação da tecnologia espacial.

\begin{tabular}{|c|c|}
\hline ÁREA DE ATUAÇÃO & ESTUDOS DESENVOLVIDOS \\
\hline VEGETAÇÃO & $\begin{array}{l}\text { Identificação de áreas de florestas, alterações florestais em parques, reservas, } \\
\text { florestas nativas ou implantadas, quantificações de áreas, sinais de queimadas } \\
\text { recentes }\end{array}$ \\
\hline AGRICULTURA & $\begin{array}{l}\text { Identificação de campos agrícolas, quantificação de áreas, monitoramento do } \\
\text { desenvolvimento e da expansão agrícola, quantificação de pivôs centrais, auxílio em } \\
\text { previsão de safras, fiscalizações diversas. }\end{array}$ \\
\hline MEIO AMBIENTE & $\begin{array}{l}\text { Identificação de anomalias antrópicas ao longo de cursos d água, reservatórios, } \\
\text { florestas, cercanias urbanas, estradas; análise de eventos episódicos naturas } \\
\text { compatíveis com a resolução da Câmera, mapeamento de uso do solo, expansões } \\
\text { urbanas }\end{array}$ \\
\hline ÁGUA & $\begin{array}{l}\text { Identificação de limites continente-água, estudos e gerenciamento costeiros, } \\
\text { monitoramento de reservatórios }\end{array}$ \\
\hline CARTOGRAFIA & $\begin{array}{l}\text { Dada a sua característica de permitir visadas laterais de até } 32^{\circ} \text { a leste e a oeste, } \\
\text { em pequenos passos, possibilita a obtenção de pares estereoscópicos e a } \\
\text { conseqüente análise cartográfica. Essa característica também permite a obtenção } \\
\text { de imagens de certa área no terreno em intervalos mais curtos, o que é útil para } \\
\text { efeitos de monitoramento de fenômenos dinâmicos }\end{array}$ \\
\hline $\begin{array}{l}\text { GEOLOGIA E } \\
\text { SOLOS }\end{array}$ & Apoio a levantamentos de solos e geológicos \\
\hline EDUCAÇÃO & $\begin{array}{l}\text { Geração de material de apoio a atividades educacionais em geografia, meio } \\
\text { ambiente, e outras disciplinas }\end{array}$ \\
\hline
\end{tabular}

\section{Processamentos Digitais de Imagens (PDI)}


Os processamentos digitais envolvidos nas imagens dos sensores remotos são indispensáveis para a identificação e visualização dos objetos da superfície da terra presentes nas imagens capturadas por aqueles.

As imagens apresentam várias distorções espaciais causadas pelos movimentos dos satélites, não tendo nenhuma precisão cartográfica em relação ao posicionamento dos objetos (x-latitude e y-longitude) na superfície terrestre. A aplicação de técnicas de processamento digital de imagens permite ajustar com novos arranjos numéricos que possibilitam a extração de informações confiáveis das imagens.

As técnicas de processamento de imagens orbitais têm como função corrigir, restaurar, realçar e individualizar feições de interesse presentes nas imagens coletadas da superfície terrestre (SCHOWENGERDT, 1997; LILLESAND \& KIEFER, 1994).

A aplicação destas técnicas proporciona às imagens dos sensores remotos uma melhor qualidade tanto visual como dos dados. Além, de proporcionar uma extração confiável e efetiva dos dados contidos e capturados pelos sensores.

O nível de pré-processamento varia desde produtos com correção radiométricas, atmosféricas e geométricas simples utilizando as efemérides do satélite até aos níveis de correção geométrica com pontos de controle (coordenadas) fornecidos pelo usuário.

O conceito de correção radiométrica, de forma ampla, pode ser entendido como aquelas técnicas de processamento digital que modificam os níveis digitais (ND) originais da imagem para aproximar seus valores da condição ideal (CHUVIECO, 1996).

Já para CARVALHO et al.(2001) a correção radiométrica visa a conversão dos ND das imagens em valores de radiância para compensar as diferenças entre ganho e "off-set" em cada banda espectral.

Este tipo de correção de forma geral é primário sendo executada pelo pessoal técnico encarregado do processamento dos dados recebidos diretamente da estação receptora. Ela abrange a remoção de ruídos derivados do sensor e/ou da recepção do sinal como perda de linhas ou pixels isolados sem informação ou com informação errônea, e a remoção do ruído ocasionado pelas diferenças de calibração dos detectores do sensor.

A correção geométrica primária da imagem também é realizada muitas vezes na estação de recepção a partir das efemérides do satélite e os parâmetros do sistema sensor. Esta correção elimina erros sistemáticos como a rotação e a curvatura da superfície física da Terra, além da inclinação orbital.

Este tipo de correção visa compensar ou corrigir erros causados pelo movimento do satélite (varredura) e da Terra, curvatura da Terra, variações na plataforma (altitude e 
velocidade) e efeitos panorâmicos (relacionados aos tamanhos dos "pixels" coletados fora do nadir).

Basicamente, a correção pode ser feita de forma específica durante a aplicação de modelos matemáticos para a correção do tipo de fonte de erro, ou ainda no relacionamento matemático entre a localização do "pixel" e a coordenada deste ponto por sistema de coordenadas geográficas (MATHER, 1987 ; RICHARDS, 1993).

$\mathrm{Na}$ verdade, o conceito de correção geométrica tem como função modificar a localização ou posição espacial dos pixels que compõem uma imagem. Ou seja, essa modificação nas posições dos pixels da imagem está relacionada com o processo de georeferenciamento da mesma.

Segundo CRÓSTA (1992), a correção geométrica é definida como a transformação de uma imagem de modo que ela assuma as propriedades de escala e de projeção de um mapa. Essa correção calcula a relação entre dois sistemas de coordenadas pela definição de pontos de controle no terreno em um mapa.

A correção atmosférica é um processo de retificação dos ND da imagem para eliminar a influência da atmosfera na radiação eletromagnética (REM) durante o percurso fonte - alvo - sensor. Essa radiação é afetada durante o percurso citado por retroespalhamento e absorção de gases e aerossóis.

A correção da interferência da atmosférica é importante para minimizar os efeitos de espalhamento e também em relação às mudanças de geometria satélite-sol (sombreamento topográfico). A atmosfera tem alta influência na resposta dos alvos pela sua absorção ou espalhamento.

Os efeitos de absorção e espalhamento da atmosfera são fenômenos ocasionados por partículas em suspensão e por moléculas de gases existentes na atmosfera. O que pode reduzir o sinal proveniente pelo alvo ocasionando um baixo contraste nas imagens orbitais (SLATER, 1980).

Para CHEN et al.(1986) existem modelos que corrigem o efeito da atmosfera nas imagens como modelos que simulam as propriedades ópticas da atmosfera ou utilizam alvos presentes na área imageada com valores de reflectância conhecida.

Mas, existem correções simples como as técnicas de realce que normalmente melhoram apenas visualmente os dados de imagem original ou bruta (sem contraste). Este tipo de correção apenas realiza a distribuição dos valores de ND que se encontram concentrado apenas em uma parte da variação tonal permitida $(0-255)$. 
A diferenciação dos alvos tem uma grande importância para a interpretação das imagens melhorando a qualidade visual e enfatizando as características de interesse para um estudo específico. A principal vantagem desta técnica é que este procedimento de processamento não altera o padrão de resposta do histograma original, simplesmente expande suas extremidades (CRÓSTA, 1992).

Existem varias manipulações de contraste podemos citar algumas operações como: Mínimo e Máximo ou Linear, Raiz Quadrada, Quadrado, Logaritmo, Negativa e Equalizações (INPE, 2000).

Todos estes tipos de contraste citados são classificados como modificações da escala de cinza, ou seja, operações pontuais. Existem também as filtragens que fazem parte das operações locais que podem ser divididas em: Lineares e Não-lineares. E em cada um destas operações existem subdivisões que podem proporcionar a eliminação de ruídos sem muita alteração nas imagens, realçar suas características, suas direções e feições pela utilização de mascaras entre outras funções.

Continuando com as técnicas de processamento de imagens orbitais falaremos das seguintes: a) Índices de Vegetação, b) Modelo Linear de Mistura Espectral, c) Segmentação e d) Classificação Digital das Imagens.

a) Índices de Vegetação:

Nos estudos geográficos, onde a vegetação é uma componente do espaço que necessita de uma abordagem, os Índices de Vegetação (IV) estão diretamente relacionados com o comportamento espectral da vegetação. E têm grande importância na determinação da densidade de fitomassa foliar fotossinteticamente ativa por unidade de área. Estes índices possibilitam o estudo e monitoramento da cobertura vegetal da superfície terrestre.

O intuito da geração destes índices é quantificar a densidade da cobertura vegetal realçando o contraste de superfícies diferentes da vegetação. Como por exemplo, a discriminação de uma área contendo floresta e outra de mata ciliar ou desmatamento (solo desnudo).

Porém, antes da obtenção dos índices é necessária à aplicação de correções atmosféricas e radiométricas, e posteriormente a correção geométrica (correções já apresentadas anteriormente). A geração destes índices é realizada por operações aritméticas entre as bandas espectrais dos sensores dos satélites.

As bandas espectrais que têm maior evidência de contraste da vegetação estão localizadas na região do vermelho (Faixa do Visível) e do infravermelho próximo (IVP). Estas são as mais importantes por estarem presentes em todos os satélites de SR e Rodríguez, A. C. M. 
principalmente por fornecerem mais de 90\% das informações contidas na vegetação (KAUTH \& THOMAS, 1976; TUCKER, 1979; JACKSON, 1983; BARET et al., 1989; MOREIRA, 1997).

A aplicação dos IV envolve a combinação de dados de duas ou mais bandas espectrais dependendo da relação de estudo com os parâmetros da vegetação como, por exemplo, o Índice de Área Foliar (LAI) e a Fração Absorvida da Radiação Fotossinteticamente Ativa (FAPAR) envolvidas em estudos florestais e agronômicos (MORAN et al., 1995).

A presença de maior contraste na região do IVP e menor no vermelho são indicadores de alto vigor ou grande densidade de cobertura vegetal. Quanto maior o IV, mais densa é a fitomassa verde, ou seja, à medida que aumenta a quantidade de vegetação aumenta também a reflexão na banda do IVP e diminui consideravelmente a reflexão na banda do vermelho fazendo com que o aumento da razão seja potencializado realçando assim a vegetação (KAZMIERCZAK, 1996).

Os cálculos para o IV são realizados pelos dados espectrais das imagens com os valores digitais (ND), de reflectância ou de radiância. A partir dos dados digitais da imagem, os valores obtidos são considerados apenas relativos impossibilitando sua utilização como referência. Os quais não podem estabelecer nenhuma correlação com índices advindos de valores de reflectância ou radiância, ou mesmo com os parâmetros biofísicos da vegetação (JACKSON \& HUETE, 1991).

A redução do número de bandas (dimensionalidade espectral) no índice, obtenção do índice com valores físicos altamente correlacionados com variáveis na agricultura e a redução do efeito do relevo (declividade e orientação) na caracterização espectral de alvos são algumas das vantagens para a utilização do índice de vegetação em estudos de levantamento do uso e cobertura da terra (JACKSON \& HUETE, 1991; MOREIRA, 1992; CHUVIECO, 1996).

Existem vários índices para estudo da vegetação e em FLEMING (2001) cita alguns indices como: SR (Simple Ratio), SAVI (Soil Adjusted Vegetation Index), ARVI (Atmospheric Resistant Vegetation Index), GARI (Green Atmospherically Resistant Vegetation Index), NDVI (Normalized Difference Vegetation Index) e o EVI (Enhanced Vegetation Index).

No entanto iremos falar apenas dos índices que foram empregados neste trabalho de pesquisa como o NDVI (Normalized Difference Vegetation Index) e o EVI (Enhanced Vegetation Index).

Historicamente o NDVI proposto por ROUSE et al. (1973) foi aplicado nas imagens do satélite LandSat (MSS7 e MSS5) para o monitoramento da vegetação na região central Rodríguez, A. C. M. 
(Great Plains) dos Estados Unidos. Este índice tem uma relação normalizada pela razão da diferença da reflectância das bandas do Infravermelho Próximo (pnir) com o Vermelho (pred) pela sua própria somatória (DEERING et al., 1975).

O NDVI é o responsável pela construção das bases de dados globais pelo sensor AVHRR ("Advanced Very High Resolution Radiometer") a bordo do satélite NOAA ("National Oceanic and Atmospheric Administration") (JACKSON, 1983; JENSEN, 1996 e HUETE et al., 1999). Este índice é um dos mais antigos utilizados pela comunidade acadêmica.

O NDVI é utilizado em estimativas de produção primária, monitoramento de padrões de seca e de florestas tropicais, além de correlacionar as variáveis ambientais como precipitação, temperatura e tipos de solos. Este índice é calculado a partir dos números digitais (DN), de radiância ou de reflectância, pois não apresenta unidades de grandeza.

Já o EVI proposto por HUETE et al. (1994 \& 1997) está centrado desde a criação do Projeto MODIS, mas especificamente no seu produto MOD13. O objetivo é a redução dos fatores de ruído das assinaturas espectrais coletadas pelo sensor.

Assim, foram criados modelos com base na função de reflectância bidirecional (BRDF) com intuito de reduzir ao mesmo tempo o efeito de fundo (solo) e principalmente a influência atmosférica.

O EVI é na verdade um índice otimizado que reduz a influência da atmosfera baseando-se na premissa de quanto maior a concentração de aerossóis maior será a diferença de valores de radiância entre as bandas do azul e vermelho (KAUFMAN \& TANRÉ, 1992). LIU e HUETE (1995) afirmam que tanto a influência da atmosfera como a do solo devem ser anuladas simultaneamente devido às mesmas serem interativas.

O EVI utiliza as mesmas bandas do NDVI e mais a banda do azul (blue), além da correção dos aerossóis e efeito de fundo $\left(\mathbf{C}_{1}\right.$ e $\left.\mathbf{C}_{2}\right)$; fator de ganho $(\mathbf{G})$ igual dois e meio $(2,5)$; e também um fator de correção da influência do solo que na verdade se trata do ajuste para o substrato (L) igual a um (1) para os coeficientes de correção do espalhamento atmosférico $\mathbf{C}_{1}$ e $\mathbf{C}_{2}$ igual a seis $(6)$ e, sete e meio $(7,5)$ respectivamente (TABELA 11).

TABELA 11 - Os índices EVI e NDVI.

\begin{tabular}{|c|c|c|}
\hline ÍNDICE DE VEGETAÇÃO & REFERÊNCIA & DEFINIÇÃO \\
\hline NDVI ("Normalized Difference Vegetation Index") & $\begin{array}{l}\text { ROUSE et al. (1973) } \\
\text { ÍNDICE DE RAZÃO }\end{array}$ & $\frac{\text { pnir - pred }}{\text { pnir + pred }}$ \\
\hline EVI ("Enhanced Vegetation Index") & $\begin{array}{l}\text { HUETE (1994 \&1997) } \\
\text { ÍNDICE DE RAZÃO }\end{array}$ & $\frac{(\text { pnir }- \text { pred })}{\left(\text { pred }+C_{2} L+\rho n i r+C_{1} \rho a\right)}{ }^{*} G$ \\
\hline
\end{tabular}

FONTE: Adaptado de FLEMING (2001). 
A FIGURA 21 mostra o mosaico (composição) de 16 dias de imagens (27 Jul à 11 Ago/2009) do NDVI e EVI do sensor MODIS do satélite TERRA do estado de São Paulo.

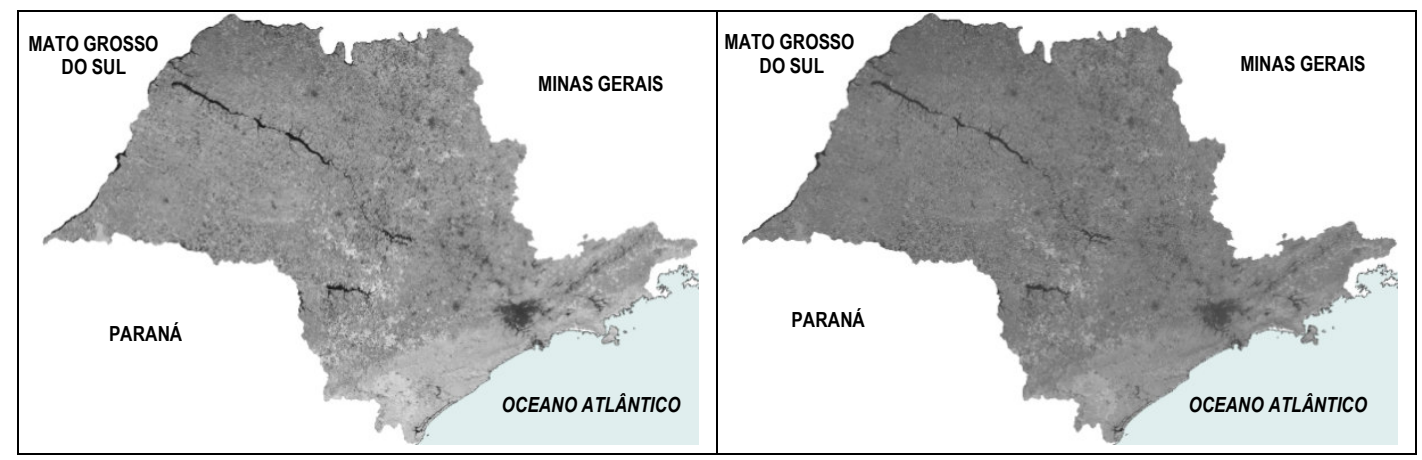

Figura 21 - Mosaico de imagens NDVI e EVI (MODIS) do estado de São Paulo.

FONTE: NASA (2009).

b) Modelo Linear de Mistura Espectral (MLME):

O MLME é um modelo matemático utilizado para melhor identificar os alvos num produto SR. Esse modelo propicia uma fotointerpretação com maior rapidez e precisão no levantamento de tipos de uso e cobertura da terra.

O comportamento espectral dos alvos frente à REM já foi descrito anteriormente, porém é necessário recordarmos alguns conceitos importantes para entendermos melhor sobre a aplicação do MLME nas imagens de satélite.

Das imagens de satélite de SR são coletados dados por um sistema sensor que capta a radiância dos alvos ou objetos contida dentro de cada elemento de resolução do sensor chamado "pixel" (picture element).

Dentro do pixel, essa radiância é resultado basicamente das características dos sensores e também das características espectral e espacial dos objetos imageados por este (SHIMABUKURO \& SMITH, 1988). Entretanto, a radiância coletada de uma determinada área da superfície terrestre é a soma das radiâncias de todos os objetos dentro do campo de visada instantânea (Instantaneous Field of View - IFOV) do sensor.

A integração ou soma dessas radiâncias provenientes de diferentes objetos dentro do IFOV representa na verdade uma combinação linear de diversos tipos de cobertura do terreno no pixel. Ou seja, é o valor do pixel e este não representa o valor de apenas um objeto, porém da interação de vários (VERONA, 2002).

Cada objeto registrado pelo IFOV na superfície terrestre apresenta suas características físico-químicas próprias, definindo-se assim uma assinatura espectral única à REM. Portanto, a radiação detectada pelo sensor no pixel será sempre a mistura de 
diferentes assinaturas espectrais como: solo, água, vegetação, área urbana, etc., mais a contribuição atmosférica (SHIMABUKURO \& SMITH, 1988).

Os problemas de mistura identificados no pixel determinam que ele não seja representativo de nenhum objeto detectado na superfície. Portanto, o pixel é considerado como uma combinação linear de assinaturas espectrais de cada componente ou objeto existente na mistura (WATRIN et al., 2003).

Devido a essa combinação linear espectral é difícil encontramos pixels totalmente puros nas imagens de satélite (RODRIGUEZ YI et al., 1998). Por isso, necessitamos identificar as proporções das diferentes assinaturas espectrais que compõem um pixel.

O MLME estima as proporções dos componentes existentes no pixel como: solo, vegetação e água ou sombra a partir de suas assinaturas espectrais identificadas nas imagens de satélite, gerando imagens-fração solo, vegetação e sombra (SHIMABUKURO \& SMITH, 1988).

Para a análise e obtenção das respostas espectrais das componentes de mistura é necessária a captura pelo cursor do mouse dos valores de assinatura espectral na própria imagem. Esses valores obtidos da imagem são os pixels puros, os quais são representativos das porções da vegetação, do solo e da água na superfície terrestre (FIGURA 22).

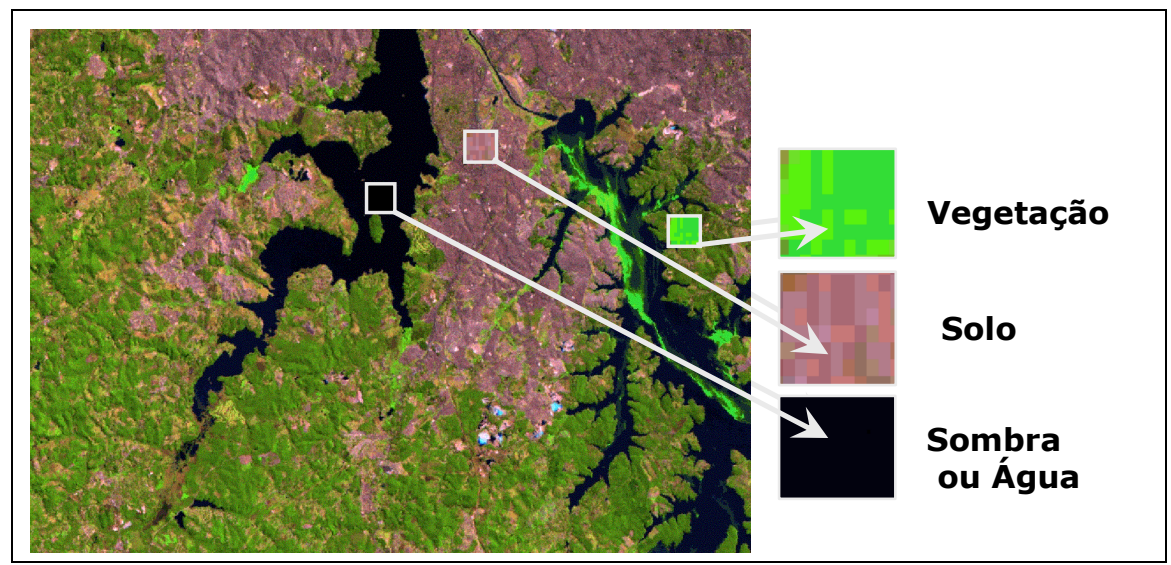

FIGURA 22 - Captura de pixels puros diretamente na Imagem Landsat.

Os principais métodos para estimar as proporções das componentes (vegetação, solo e sombra) dentro de um pixel baseado no critério de Mínimos Quadrados são: Mínimos Quadrados com Restrições, Mínimos Quadrados Ponderado e a Combinação entre Transformação de Principais Componentes e Mínimos Quadrados.

O método dos Mínimos Quadrados com Restrições é simples e rápido utilizado quando o número de componentes é igual a três. O Ponderado é mais geral.

Já a Combinação entre Transformação de Principais Componentes e Mínimos Quadrados diminui o número de equações no sistema aplicando primeiramente uma 
transformação de principais componentes seguida pelo método de estimação por Mínimos Quadrados. Este critério apresenta como vantagem a rapidez computacional para um número de componentes diferente de três (INPE, 2008).

Após a estimação das proporções de cada componente dentro dos pixels, geramse como produto novas bandas a partir das originais referentes às imagens-fração vegetação, solo e sombra (FIGURA 23).

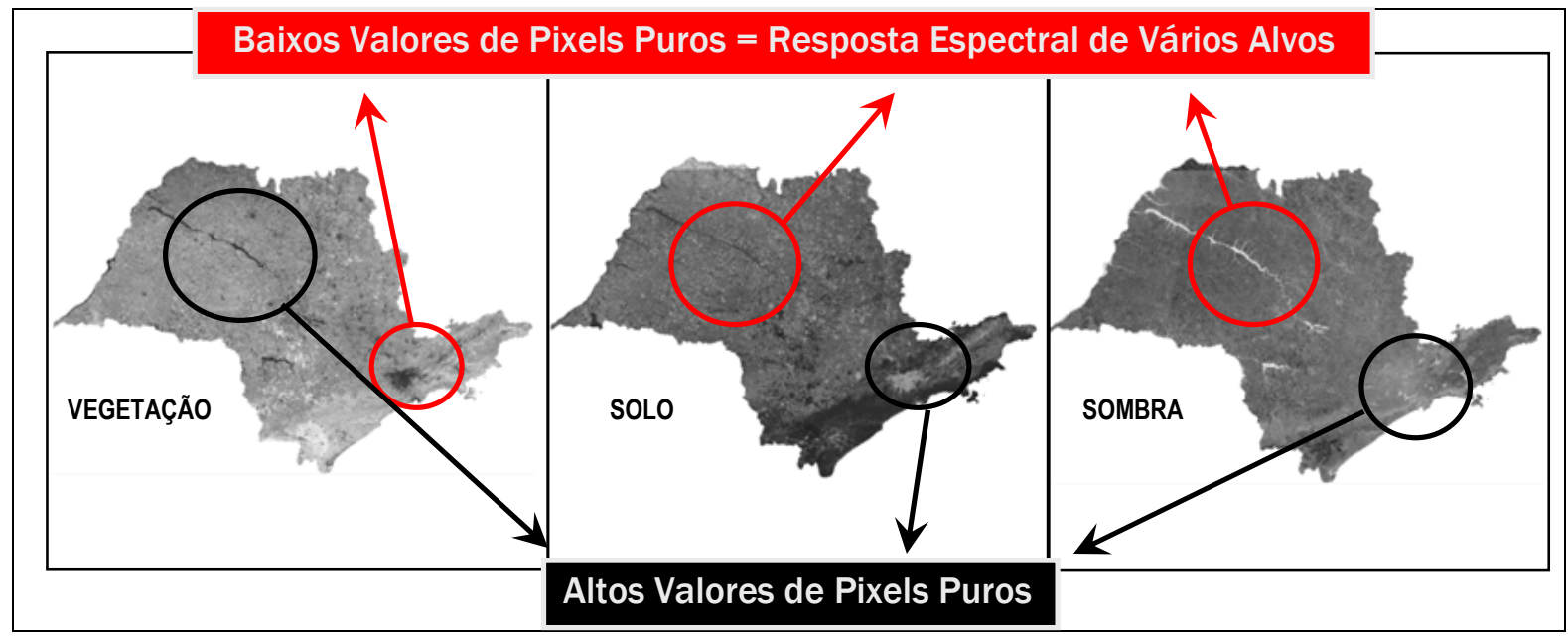

FIGURA 23 - Captura do pixel puro (vegetação, solo e água).

O MLME apresenta como objetivos básicos (1) reduzir o volume de dados a serem utilizados no processamento digital de imagens, e (2) realçar os alvos de interesse de um determinado estudo.

Dentre as aplicações do MLME no estudo da vegetação e uso e cobertura da terra podemos destacar vários artigos como: PEREIRA et al. (1998), VERONA (2002), MELLO et al. (2003), HAYASHI et al. (2003) e SHIMABUKURO et al. (1999), pois houve considerável aumento no desenvolvimento de amplas pesquisas científicas nos últimos anos.

c) Segmentação:

Para executamos a classificação digital nas imagens se necessita inicialmente identificar as regiões homogêneas existentes pela técnica de segmentação. Essa técnica é basicamente um processamento de análise de imagens digitais, onde nestas são divididas as regiões espectralmente homogêneas que correspondem a áreas de interesse de uma pesquisa.

A segmentação pode ser realizada das seguintes formas: por Crescimento de Regiões e por Detecção de Bordas e Bacias. Daremos destaque apenas ao Crescimento de Regiões por esta ter sido aplicada neste trabalho de pesquisa. No entanto, para qualquer informação sobre a Detecção de Bordas e Bacias procurar por ERTHAL et al. (1991) e ERTHAL (1998). 
O Crescimento de Regiões divide a imagem em um número de regiões homogêneas. Onde, cada uma destas é identificada por um rótulo que originará uma imagem final rotulada. Essas regiões são agrupadas em áreas espacialmente adjacentes por um critério de similaridade contendo um pixel ou um conjunto de pixels (INPE, 2000).

$\mathrm{Na}$ verdade, este método consiste na agregação de pixels com propriedades similares em conjuntos denominados regiões, cujas bordas definem os seus contornos. A extração destas bordas é realizada pelo algoritmo de ERTHAL et al. (1991).

Desta forma, uma região é um conjunto de pixels adjacentes que exibe uma homogeneidade com relação aos seus atributos (ND), tais como: média, variância, área, perímetro, excentricidade e linearidade média de bordas.

A segmentação por crescimento de regiões é realizada nas imagens em níveis de cinza baseado em suas características intrínsecas como a descontinuidade e a similaridade entre as regiões. A descontinuidade está relacionada com a mudança dos níveis de cinza enquanto que a similaridade está ligada à união dos pixels em função de sua semelhança nos níveis de cinza em relação aos seus pixels vizinhos (ERTHAL, 1998).

$\mathrm{Na}$ aplicação dessa técnica é necessário definir dois limiares:

\section{1 - Limiar de Similaridade:}

Este representa o limiar abaixo do qual duas regiões são consideradas similares, e então agrupadas em uma única região. Este limiar é definido pela distância Euclidiana mínima entre as médias das regiões consideradas (ERTHAL et al., 1991).

Esse limiar é muito importante, pois é ele quem determina a precisão da segmentação. Caso este limiar seja muito baixo, o segmentador atribuirá muitos pixels às regiões de igual condição, porém se ele for muito alto, os pixels serão incorretamente agregados em diferentes regiões (MOURA, 2000).

\section{2 - Limiar de Área:}

É o valor de área mínima, dado em número de pixels, para que uma região seja individualizada. Ao final da segmentação, se obtém uma representação simbólica da imagem: uma lista de regiões com seus atributos, uma lista de arcos (fronteira entre duas regiões) com seus atributos (força e orientação média das bordas) e uma lista de nós (ponto de encontro de três ou mais regiões) (ERTHAL et al.,1991).

A FIGURA 24 mostra os contornos das regiões extraídas de uma imagem obtida pelo algoritmo de crescimento de regiões sobreposto à imagem original. 


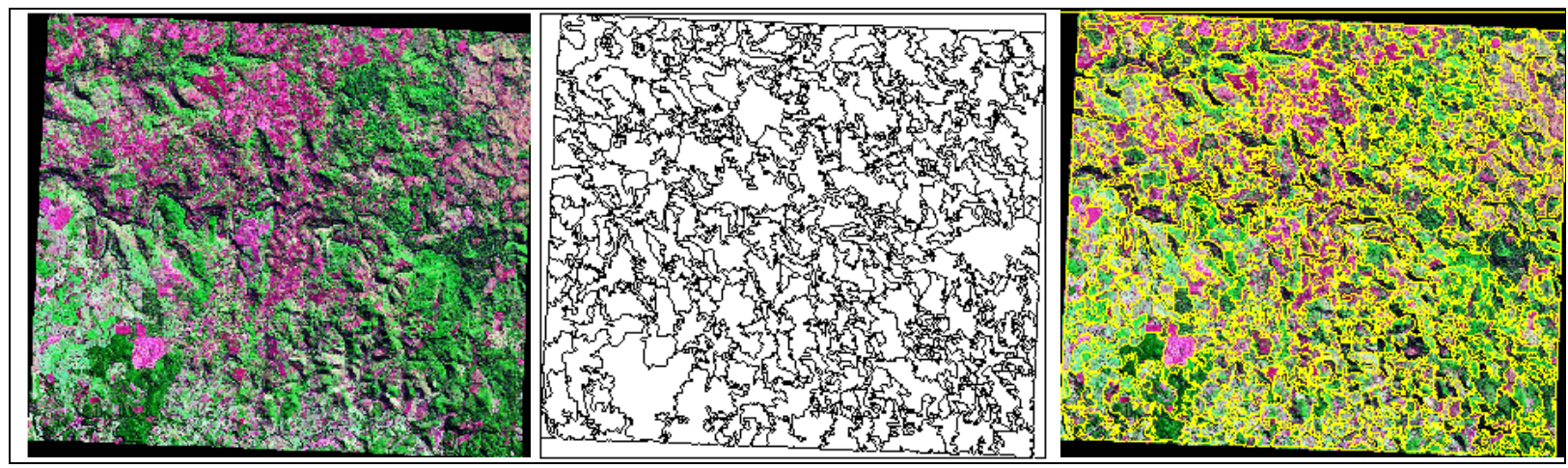

FIGURA 24 - Imagem original + segmentação + imagem segmentada.

A segmentação de imagens digitais tem grande importância por que veio para aperfeiçoar a tradicional interpretação visual. O que satisfatoriamente substituir inúmeras etapas da dessa interpretação restando ao foto intérprete apenas a associação dos polígonos gerados á suas respectivas classes temáticas.

d) Classificação Digital das Imagens:

A Classificação Digital das Imagens do SR vem a ser os procedimentos utilizados para separar e identificar os objetos na superfície terrestre detectado pelos sensores dos satélites. Ou seja, cada pixel ou região presente em uma imagem digital é associado a uma determinada classe que descreve um determinado uso como: a área urbana, tipos de florestas, tipos de solos, culturas agrícolas e outras feições de interesse.

CRÓSTA (1992) descreve que essa classificação é um processo que extrai informações das imagens digitais para o reconhecimento de padrões espectrais e objetos homogêneos com o auxílio da inspeção visual humana.

O INPE (2000) descreve que o processo de classificação pode ser basicamente dividido em dois tipos de classificadores: classificadores por pixel e os por região.

Os classificadores por pixel que utilizam as informações espectrais isoladas referentes a cada pixel para agregar as regiões homogêneas, podemos citar os mais comuns como: Máxima Verossimilhança (MAXVER), Distância Mínima e Método do Paralelepípedo.

Enquanto que os classificadores por região utilizam não somente as informações espectrais de cada pixel, mas também as informações espaciais que envolvem a relação entre os pixels e seus vizinhos. Procurando simular o comportamento de um foto intérprete em relação ao reconhecimento das regiões homogêneas na imagem pelas propriedades espectrais e espaciais de cada cena (INPE, 2000).

A classificação por regiões é feita primeiramente com a partição em regiões da imagem pela segmentação. E posteriormente, em cada região é feita associação de uma Rodríguez, A. C. M. 
classe, onde todos os pixels existentes em uma determinada região são agrupados a uma mesma classe.

Assim, para um melhor entendimento do processo de classificação por regiões abaixo são descritos os passos a serem seguidos para este procedimento (BINS et al., 1992):

\section{I - Extração de Regiões}

Esta etapa se extrai as informações de média e variância de cada região, definida na segmentação, considerando as bandas a serem utilizadas na classificação.

\section{II - Treinamento}

É necessário quando a classificação é supervisionada. Consiste em obter amostras de regiões representativas de cada classe de interesse. Essas amostras representam polígonos que delimitam uma determinada região pertencente a uma classe ou tema.

\section{III - Análise das Amostras}

A análise permite verificar a qualidade das amostras adquiridas, com base nas matrizes de confusão.

\section{IV - Classificação}

A classificação por regiões consiste em identificar e rotular uma classe determinando um grupo de regiões, e atribuindo uma determinada cor. Existem dois tipos classificadores por regiões: o ISOSEG (não-supervisionado) e o BHATTACHARRYA (supervisionado).

O ISOSEG é um algoritmo de agrupamento de dados não-supervisionado que é aplicado em um conjunto de regiões caracterizadas por seus atributos estatísticos de média, matriz de covariância e área. Essas regiões são agrupadas levando em consideração certa medida de similaridade entre si, utilizando a distância de Mahalanobis entre as classes e as regiões selecionadas a uma relação de pertinência com essas respectivas classes.

Já o BHATTACHARRYA utiliza as amostras de treinamento para estimar a função densidade de probabilidade para as classes apontadas. Depois, avalia cada região através da distância de Bhattacharrya para cada classe selecionada. Então, a classe que apresentar a distância menor será atribuída ou agregada à região avaliada (INPE, 1999).

\section{$V$ - Mapeamento para Geoclasses}

As geoclasses são chamadas de temas, ou seja, representam as classes prédeterminadas pelo foto interprete. O mapeamento é resultante da classificação que associa as geoclasses previamente definidas pelo foto intérprete. Segundo INPE (1999), o mapeamento permite transformar a imagem classificada (modelo imagem) para uma 
imagem raster do modelo temático, onde as geoclasses utilizadas são as correspondentes às informações identificadas na superfície terrestre.

O modelo temático é o mapa propriamente dito, o qual é representado por símbolos gráficos ou cores. Onde, cada cor estará relacionada a uma única classe pré-definida pelo usuário ou foto intérprete durante o Treinamento.

Existem na literatura vários trabalhos que utilizaram a segmentação e classificação digital para monitorar ou mapear uso e cobertura da terra, tipos de vegetação, avaliar plantio de diversas culturas agrícolas, entre outras (SHIMABUKURO et al., 1997; RODRIGUEZ YI et al., 1998; MOREIRA et al., 1998; RODRIGUEZ \& MOREIRA, 2001; MOREIRA \& SOUZA, 2001; MELLO et al., 2003).

\subsubsection{Sistema de Informações Geográficas (SIG)}

A utilização de um SIG neste trabalho de pesquisa tem como objetivo reunir o maior número de dados acerca do estado de São Paulo. E desta forma efetuar combinações, integrações e transformações acerca dos dados espaciais contidos no Banco de Dados Geográfico.

O SIG possibilitará o conhecimento, gerenciamento e atuação sobre os problemas relacionados com a geografia do estado de São Paulo. Assim, é necessário um breve levantamento histórico sobre o surgimento do SIG e alguns conceitos.

Historicamente, a relação que existe entre a sociedade e o SIG vem desde o século XVIII. Pois, a necessidade de representação dos elementos cartográficos juntamente com seu posicionamento geográfico era naquela época de grande relevância.

Podemos citar: a representação de dados sobre a população, o fluxo de tráfego, a geologia e a topografia, sobrepostos num mesmo mapa base. O que resultou no "Atlas to Accompany the Second Report of the Irish Railway Commissioners" publicado em 1838 (PARENT \& CHURCH, 1987).

E em 1954 durante pesquisas médicas do Dr. John Snow na tentativa de descobrir a ocorrência da epidemia de cólera que alastrava o centro de Londres. O médico representou espacialmente os casos de morte por cólera, o que levou na identificação do poço d’água contaminado (TUFTE, 1997).

Mas, foi apenas por volta dos anos 60 que realmente surgiu o SIG. O seu objetivo era facilitar a sobreposição e combinação de diversos tipos de dados em um único mapa. $O$ que acarretou na reunião de diversos mapas em folhas transparentes gerando uma grande 
produção de papel e dificultando o armazenamento e atualização manual (CÂMARA et al., 1996b).

Desta forma, o investimento na construção de um SIG era fato. E as primeiras tentativas para seu desenvolvimento ocorreram na Grã Bretanha e nos Estados Unidos com objetivo de diminuir os custos de produção e atualização de mapas.

Mas, o primeiro SIG propriamente dito se desenvolveu no Canadá pelo Dr. Roger TOMLINSON (1998) durante a execução do mapeamento do uso do solo. Onde, foi desenvolvido o Canadian Geographic Information System (CGIS) pelo governo.

O primeiro SIG foi o sistema CAD cartográfico que desenhavam objetos e possuíam ligações bem rudimentares com o Banco de Dados, sem falar que manipulava pouca quantidade de dados (NEWELL \& THERIAULT, 1990).

Estes sistemas eram responsáveis pela recuperação de dados, classificação e simbolização automática, mas seu objetivo principal era a exibição de dados ao invés da análise. Pois, estes sistemas tinham uma estrutura simples de dados sem a criação de informações topológicas (COWEN, 1988).

Na década de 80 no Brasil surge à introdução ao SIG pelo professor Jorge Xavier da Silva da Universidade Federal do Rio de Janeiro (UFRJ). E em 1982 recebemos a visita do Dr. Roger TOMLINSON (1998), o pioneiro na criação do SIG, o que incentivou o aparecimento de vários grupos de pesquisas interessados no desenvolvimento de SIG (MOREIRA, 2001).

E década de 90, surgem os SIG baseados em banco de dados geográficos concebidos para uso em ambientes cliente/servidor, acoplado à gerenciadores de banco de dados relacional e com pacotes adicionais para processamento de imagens.

O SIG se diferenciava de um sistema CAD não apenas na automatização da função de desenho, mas também na criação e associação de atributos gráficos e não-gráficos de recursos cartográficos. A sua conceituação para o pioneiro TOMLINSON (1998) vinha da construção de mapas com a necessidade de apresentação de dados geográficos, ambientais ou demográficos separadamente ou em combinação.

Os atributos vinculados ao SIG representam relações de topologia pelos recursos de ponto, linha e área a partir de dados com ligação e configuração espacial. E é essa estrutura topológica existente que possibilita a realização de diversos tipos de análise de dados geográficos.

A principal importância do SIG é a manipulação de grandes volumes de dados que os métodos convencionais não resolveram. ARONOFF (1989) complementa que os SIG 
foram projetados para coleta, armazenamento, análise de objetos e fenômenos, onde a localização geográfica é uma característica importante ou crítica nas análises geo-espaciais.

Já CÂMARA et al. (1996b) dizem que os SIG comportam diferentes tipos de dados e aplicações em várias áreas de conhecimento como, por exemplo, cartografia, agricultura, manejo florestal, gestão ambiental, geografia, geologia, oceanografia, administração dos recursos naturais, monitoramento costeiro, planejamento regional e urbano entre outras.

Outras aplicações com os SIG são relatados por diversos autores como BURROUGH et al. (1998), SCHOLTEN e STILLWELL (1990) que afirmam a importância destes sistemas de relação espacial com objetos geográficos (topologia) facilitando assim a manipulação e análise de diversos estudos ambientais.

Segundo CÂMARA \& MEDEIROS (1996a), as principais características de um SIG são:

a) inserir e integrar, numa única base de dados, informações espaciais provenientes de dados cartográficos, censitários, cadastro urbano e rural, imagens de satélite, redes e modelos numéricos de terreno;

b) oferecer mecanismos para combinar as várias informações, através de algoritmos de manipulação e análise, bem como para consultar, recuperar, visualizar e plotar o conteúdo da base de dados georeferenciados.

A configuração de um SIG é composta de forma hierárquica e interligada uns aos outros a partir dos seguintes componentes: interface com usuário, entrada e integração de dados, funções de processamento gráfico e de imagens, visualização e plotagem, armazenamento e recuperação de dados organizados sob a forma de um banco de dados geográficos (CÂMARA et al., 1996b).

A FIGURA 25 indica o relacionamento destes componentes citados acima e suas interações encontradas na maioria dos SIG's. É claro que podem surgir diferenças devido as funções de seus objetivos e necessidades de forma distinta. Mas, em geral são estes componentes que mais aparecem na estrutura de um SIG. 


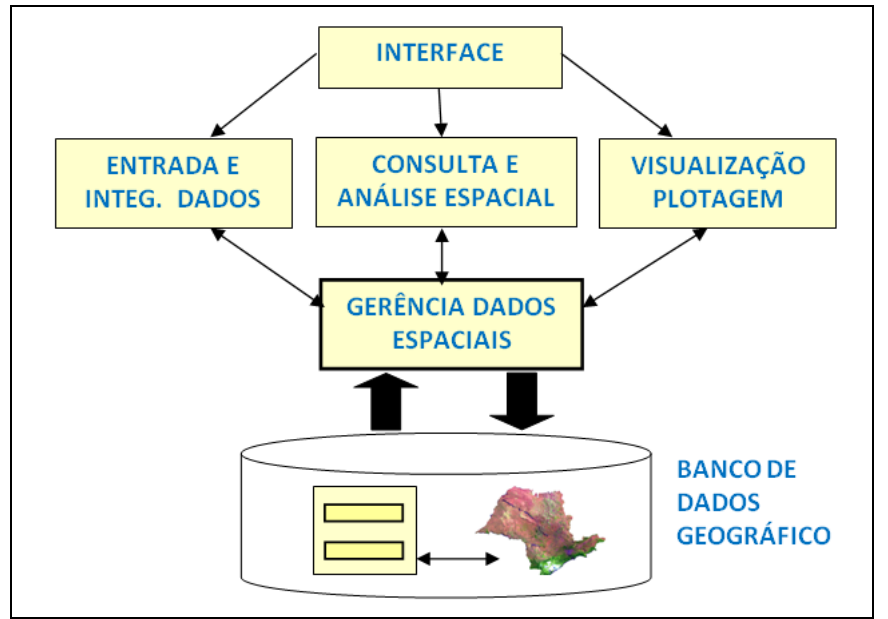

FIGURA 25 - Estrutura geral de um SIG.

FONTE: CÂMARA et al. (1996b), p. 24.

A interface com o usuário é composta por um conjunto de funções que servem de suporte de entrada e integração de dados, as quais podem ser adicionadas por menus.

Já a entrada e integração de dados envolvem os aspectos de aquisição de dados espaciais contidos em mapas, fotografias aéreas, imagens de satélite, dados de campo, dados digitalizados entre outras fontes. $\mathrm{E}$ a conversão dessa variedade de fonte de dados é de extrema importância para a alimentação do SIG (CÂMARA et al.,1996b) .

As funções de processamento gráfico e de imagens ou as consultas e análises espacial são chamadas de operadores analíticos que manipulam todo o conjunto de dados com o intuito de gerar novas informações. Os quais podemos dizer que compreendem os processamentos de tratamento dos dados, ou seja, consiste na aplicação dos algoritmos que realizam operações de pré-processamento, classificação e pós-processamento.

A visualização e plotagem é a própria visualização e impressão (plotagem) dos dados espaciais ou alfanuméricos, as mesmas são executadas a partir dos monitores de vídeos, impressoras e plotters.

Agora o armazenamento e recuperação de dados organizados sob a forma de um banco de dados geográficos é um conjunto de arquivos estruturados para facilitar o acesso à determinada informação ligadas a entidades do mundo real.

\section{Banco de Dados Cartográfico e Geográfico}

O Banco de Dados ou Base de Dados aqui descrito e construído neste trabalho de pesquisa tem com objetivo integrar, pesquisar e facilitar o acesso as informações (dados cartográficos e outros) que descrevem as entidades geográficas do estado de São Paulo. 
Em um mundo real é muito complexo tentar representar os fenômenos da natureza, assim como para o imediato e direto entendimento destes. Por isso necessitamos criar "modelos" dessa realidade com a intenção de torná-los similares com aspectos selecionados do mundo real.

O Banco de Dados é criado a partir desses modelos com o intuito de tentar conhecer essa natureza e seu estado nessa realidade. É claro, que parece ser muita pretensão do ser humano tentar modelar essa natureza com a desculpa de tentar entende-la. Mas, se voltarmos ao passado o homem já se utilizava desta forma de representar a natureza através dos mapas.

Desta forma, um Banco de Dados tem como fundamento principal promover uma visão abstrata dos dados que neles são inseridos. É claro que para o usuário que manipula estes dados é oculto em seus mínimos detalhes, assim como seu armazenamento (SILVA, 1999).

Segundo CÂMARA \& MEDEIROS (1996a) existem dois tipos distintos de Banco de Dados: a) o Convencional que tem forma simples contendo um número determinado de arquivos com dados alfanuméricos sem nenhuma referência geográfica e b) o Geográfico que além de armazenar dados alfanuméricos possui dados sobre a localização geográfica de determinada entidade.

O BD geográfico (BDG) possui uma coleção de entidades referenciadas espacialmente que atuam como modelo da realidade. Esse modelo na verdade tenta representar um conjunto selecionado de fenômenos da natureza na forma digital.

Segundo SILVA (1999) os BDG existentes em SIG possuem um conjunto de dados tabulares que estão intimamente relacionados a feições espaciais, com dados de referência geográfica ou não.

Para HANSEN (1989), de modo geral um banco de dados (BD) é uma estrutura que guarda registros de forma integrada ou partilhada, e permite que itens de dados individuais sejam usados por diferentes programas e faz a combinação de diversos conjuntos de dados.

$\mathrm{Na}$ verdade um sistema de BD é simplesmente um programa computacional normalmente de grande complexidade e que permite ao usuário mudanças de dados, atualizações, correções de erros, etc. Ele pode operar com dados: numéricos, alfanuméricos, datas entre outros.

Dentro de um BD existe separação bem distinta entre os programas de armazenamento físico dos dados com os programas de aplicação. Os programas e os dados são inteiramente independentes entre si. Ou seja, o usuário, programador ou 
especialista em aplicação não necessita ter conhecimento dos detalhes de como os dados foram armazenados, mas estes devem ser transparentes ao usuário.

Segundo SILVA (1999) é essa independência entre programas e dados que permite a execução de mudanças nos dados sem alteração nenhuma em outros componentes do sistema. Este autor exemplifica as mudanças de formato dos itens dos dados de real para inteiros ou operações aritméticas, entre outros.

Um BD possui linguagens para descrição, manipulação de dados e pesquisas de elementos espaciais da informação. Além disso, provê ferramentas de programação e tem estruturas particulares (HANSEN, 1989).

A estruturação de um BDG é feita exclusivamente pela Modelagem de Dados, a qual especifica o conjunto de aplicações necessárias para estruturar corretamente os dados armazenados (MOREIRA, 2001).

Essa estruturação guarda registros de forma integrada ou partilhada permitindo que itens de dados individuais sejam usados por diferentes programas, além de possibilitarem a combinação com diversos conjuntos de dados.

Mas, antes de falarmos da estruturação dos BDG é conveniente conhecermos os conceitos espaciais relacionados a ele como: entidade, tipos e classes de entidade, objeto, símbolo entre outros. Assim, teremos facilidade no relacionamento destes conceitos com as feições espaciais (SILVA, 1999).

A entidade corresponde a um objeto que existe e é perfeitamente distinguível de outros objetos (KORTH \& SILBERSCHATZ, 1994). E essa se refere a uma unidade "mapeável" que tem um identificador (nome ou código) e possui uma dimensão dependendo de sua escala (DCDSTF, 1988). Podemos citar um determinado tipo de agricultura ou um tipo de floresta ou ainda o grau de adensamento de uma cidade.

Os tipos de entidade podem ser representados por pontos, linhas, áreas e volume. Como exemplos têm: pontos - o número de aeroportos; linhas - o número de estradas federais; áreas - o número de polígonos de culturas diversas e volume - o volume em $\mathrm{m}^{3}$ dos açudes de uma região.

As classes de entidade equivalem à categoria da entidade com certa similaridade como, por exemplo, a classificação dos aeroportos em pequeno e grande porte ou das culturas perenes e anuais.

O objeto trata de uma representação digital do todo ou de parte de uma entidade. $\mathrm{Na}$ superfície da Terra todas as coisas que vemos são objetos em BDG. Ou seja, se a entidade 
é uma organização conceitual de um fenômeno, um objeto é uma representação digital desse fenômeno (DCDSTF, 1988).

Já o símbolo é a representação gráfica desse objeto, onde segundo MUEHRCKE (1978) é composta por um ou mais de sete elementos gráficos primários como: cor, tamanho, forma, espaço, orientação, valor e localização.

O fator geográfico é a ocorrência particular de uma entidade. Ou seja, o aeroporto de Congonhas ou a rodovia SP-270 no estado de São Paulo. E o fenômeno geográfico é a combinação de diversas entidades que formam uma unidade complexa.

Os atributos são as características descritivas de uma entidade como, os portes (capacidade) de aeroportos no estado de São Paulo. As classes de atributos é a categorização por similaridade de atributos como, as companhias que operam nesse aeroporto. E o valor de atributos é uma medida particular de um atributo para um fato de uma entidade geográfica como, o numero de vôos diários desse aeroporto.

E considerando a superfície da Terra podemos também contar com fenômenos geográficos bem definidos e demarcados, os quais têm as seguintes categorias de informações para algumas entidades especificas como: identificador, posição, propriedade espacial, características dos atributos e função da entidade.

O identificador dá o significado a cada entidade e pode ainda ter nomes geográficos particulares ou não, onde podem ser substituídos por códigos únicos.

A posição é descrita pelo tipo de estrutura adotada para as entidades espaciais como as coordenadas geográficas ou planas, e se utilizam de modelos adotados para realizar medições de distância como o datum ou o geóide.

A propriedade espacial é a que permite a categorização das entidades e ela se utilizam da posição como propriedade espacial, assim como da forma, área, volume entre outros.

As características dos atributos são as descrições das entidades para identificar um comportamento em um determinado tempo e também uma condição. E finalmente a função da entidade que se descreve como sendo o comportamento fiel das entidades.

Na TABELA 12 exemplificamos alguns tipos de dados identificados como entidades espaciais para um melhor entendimento:

TABELA 12 - Tipos de dados identificados como entidades. 


\begin{tabular}{c|c|c|c|c|c}
\hline \hline ENTIDADES & IDENTIFICADOR & $\begin{array}{c}\text { POSIÇÃO } \\
\text { (coordenadas) }\end{array}$ & $\begin{array}{c}\text { PROPRIEDADE } \\
\text { ESPACIAL }\end{array}$ & $\begin{array}{c}\text { VALOR DO } \\
\text { ATRIBUTO }\end{array}$ & $\begin{array}{c}\text { FUNÇÃO DO } \\
\text { ATRIBUTO }\end{array}$ \\
\hline FERROVIAS & Códigos & Dos pontos finais & $\begin{array}{c}\text { Conexão de } \\
\text { duas cidades }\end{array}$ & $\begin{array}{c}\text { Volume de } \\
\text { tráfego }\end{array}$ & Uso \\
\hline AQUíFERO & Nome & $\begin{array}{c}\text { Para localizar na } \\
\text { superficie }\end{array}$ & Volume & $\begin{array}{c}\text { Qualidade da } \\
\text { água }\end{array}$ & $\begin{array}{c}\text { Mudanças de nível } \\
\text { de água }\end{array}$ \\
\hline POÇOS & ID-número & $\begin{array}{c}\text { Para localizar na } \\
\text { superficie }\end{array}$ & Profundidade & $\begin{array}{c}\text { Tamanho do } \\
\text { furo }\end{array}$ & Destinação \\
\hline ILHAS & Nomes & Do perímetro & Área total & Composição & Lazer \\
\hline \hline
\end{tabular}

FONTE: DCDSTF (1988).

\section{SISTEMA - SPRING}

A escolha pelo SIG software SPRING para o tratamento dos dados espaciais do estado de São Paulo é explicada devido sua disponibilidade gratuita e por ser um produto brasileiro de grande aceitação a nível nacional e internacional. Além de sua fácil interação com o usuário, funcionalidades, versatilidade, sistema amigável com outros softwares do mercado, aplicabilidade e apoio técnico por parte dos desenvolvedores no INPE (CÂMARA et al., 1996b).

FELGUEIRAS (2006) descrevendo este software diz que os dados geográficos são representados digitalmente de acordo com estruturas matriciais e vetoriais. Onde a primeira armazena dados de imagens, mapas temáticos e informações de modelos numéricos do terreno. Essa definição está mais ligada ao software SPRING, onde o autor citado faz parte da equipe de construção do mesmo.

E a segunda guarda pontos, linhas, e polígonos, as quais constituem as informações temáticas (mapas de solo, mapas de drenagem, etc.), cadastrais (cadastros urbanos, rurais, etc.), redes (redes viárias, redes de drenagem, etc.) e também modelos numéricos de terreno - MNT como pontos, 3D, isolinhas e TIN.

O SPRING surgiu da evolução do antigo sistema SITIM (Sistema de Tratamento de Imagens) criado em 1986 pela Divisão de Processamento de Imagens - DPI do Instituto Nacional de Pesquisas Espaciais - INPE e financiado pelo Ministério da Ciência e Tecnologia - MCT.

O SITIM era um sistema operacional em MS-DOS que operava em um microcomputador pessoal, compatível com IBM-PC. E tinha o objetivo de integrar as imagens digitais com mapas e com outras medições realizadas no terreno (INPE, 2008).

Em conjunto com o SITIM foi desenvolvido também pela DPI um Sistema de Informação Geográfica, o SGI. Assim, os dois sistemas SITIM e SGI operavam integrados 
originando o famoso SITIM/SGI utilizados naquela época por mais de 150 universidades e institutos de pesquisa até por volta de 1994 (FELGUEIRAS, 2006).

As pesquisas voltadas na construção do SPRING já tinha se iniciado desde o ano de 1991. A DPI tinha em mente suprir as necessidades da busca de soluções acerca de problemas específicos da realidade brasileira. E para isso o domínio tecnológico entre a equipe se tornou uma meta para enfrentar novos desafios detendo de total autonomia na criação de um novo SIG.

É claro que foram utilizados e pesquisados vários SIG's existentes no mercado para a construção bases e alicerces na construção do SPRING. E o principal objetivo era atender as ciências terrestres, assim surgem às primeiras versões que eram absolutamente utilizadas internamente nas dependências do INPE.

Mas, logo com a divulgação deste software começou a sua difusão e atualmente contamos com a sua utilização por dezenas de instituições governamentais, não governamentais, empresas públicas e privadas no Brasil e em outros países (FELGUEIRAS, 2006).

O SPRING encontra-se distribuído gratuitamente pela Internet no site:<http://www.dpi.inpe.br/spring> em português, inglês e espanhol desde 1996. E para adquiri-lo basta apenas se cadastrar o que constitui um grande avanço em relação aos programas (SIG's) utilizados em levantamento de recursos naturais.

Segundo FELGUEIRAS (2006) conta-se com mais de 72.500 usuários do mundo inteiro cadastrados na página de download do SPRING. E só no Brasil nos aproximamos de $70 \%$ cadastrados. Mas, este autor ressalta que o simples download não garante sua utilização. O que acontece é que um único usuário faz o download e distribuir para um grande numero de computadores utilizados por vários usuários.

Neste site não se encontra apenas a disponibilização da versão mais atualizada, mas também de versões antigas juntamente com acesso a banco de dados já construídos com algumas informações geográficas de vários estados e municípios brasileiros.

O SPRING permite o intercâmbio de informações com outros softwares como, por exemplo: ENVI, PCI, IDRISI, Maptitude, Erdas, Ermapper, Ilwis entre outros.

Sua concepção em um SIG de segunda geração tinha como objetivo trabalhar em ambiente cliente-servidor intencionalmente para ser acoplado a diversos sistemas gerenciadores de banco de dados. O que se tratava de um conjunto de ferramentas voltadas ao tratamento de informações espaciais. E que tinha como geração de saída: mapas 
convencionais, relatórios, arquivos digitais, e outros. Assim, os recursos podiam ser armazenados, gerenciados, manipulados e analisados (INPE, 1999).

A projeção deste software atende aos seguintes objetivos: dar suporte a um banco de dados geográficos de grande porte sem estar limitado pelos recortes das projeções cartográficas; aprimorar a integração de dados geográficos com a introdução do conceito de modelagem de geo-campos e geo-objetos; obter escalabilidade, ou seja, ser capaz de operar com funcionalidade plena tanto em microcomputadores pessoais, quanto em estações de trabalho dedicadas; e dispor de uma interface que combine aplicações comandadas por menus e uma linguagem de manipulação e consulta espacial, denominada Linguagem Espacial para Geoprocessamento Algébrico (LEGAL) (BARBOSA, 1997).

O SPRING opera com um banco de dados geográficos, armazenando a geometria dos mapas em arquivos e os atributos dos dados em um sistema gerenciador de bancos de dados (SGDB). Esse banco tem uma estrutura do tipo convencional como Dbase, Access, Oracle ou MySQL que utiliza um modelo de dados relacional com os componentes descritivo do objeto geográfico armazenado separadamente.

Os atributos convencionais no SPRING são guardados em seu banco de dados através de tabelas e os dados espaciais são identificados por uma conexão que é feita pelos identificadores chamados "id".

O modelo de dados utilizado dentro do SPRING tem como princípio os conceitos de geo-campo e geo-objeto.

Geo-campo representa a distribuição espacial de uma variável que possui valores em todos os pontos pertencentes a uma região geográfica. E Geo-objeto é o único elemento que possui atributos não espaciais e está associado a múltiplas localizações geográficas e representações gráficas, as quais a sua localização é exata e seu objeto distinguível do entorno (CÂMARA \& MEDEIROS, 1996a).

Segundo INPE (1999), algumas das principais características do SPRING são:

- Integrar, numa única base de dados, informações espaciais provenientes de fontes cartográficas, dados de censo, cadastro urbano e rural, imagens de satélite, redes e modelos numéricos de terreno.

- Oferecer mecanismos para combinar as várias informações, através de algoritmos matemáticos de manipulação e análise, além de ferramentas para consultar, recuperar, visualizar e plotar o conteúdo da base de dados geocodificados. 
Além destas características, o banco de dados do SPRING pode suportar um grande volume de dados em diversas escalas, projeções e fusos, com a capacidade de assegurar a identidade dos objetos geográficos.

O Banco de dados do SPRING é onde se armazena todos os dados geográficos manipulados através de projetos, os quais são compostos por todos os dados disponíveis neste banco.

Nos projetos os dados são organizados por categorias, as quais podem ser de seis tipos diferentes: Imagem, Temático, Numérico, Objeto, Cadastral e Não-Espacial. Os dados podem ainda ser divididos em modelos como geo-campo em categorias de Imagem, Temático e Numérico, e como geo-objeto em categorias do tipo Objeto, Cadastral, NãoEspacial e Rede, onde os mesmos são armazenados e visualizados por planos de informação (PI).

Já para FELGUEIRAS (2006) o SPRING apresenta como propósito geral as funcionalidades de entrada e saída de dados geográficos, de gerenciamento de uma base de dados geográfica, de processamento de imagens digitais, de modelagem numérica de terreno, de tratamento de dados temáticos, cadastrais e de redes.

Este sistema constitui-se de quatro aplicativos, módulos ou programas executáveis, o IMPIMA, utilizado para leitura, importação e conversões de imagens de sensoriamento remoto; o SPRING, programa principal do sistema onde são modelados e processados os dados; SCARTA, que permite a elaboração de documentos cartográficos a partir de dados previamente tratados no programa SPRING e também o IPLOT responsável pela impressão dos mapas ou cartas (INPE, 2000).

O SPRING é um programa criado fundamentalmente para aplicações ambientais, integrando dados de imagens de satélites, mapas temáticos, cadastrais e modelos numéricos de terreno.

Este software foi desenvolvido em linguagem $\mathrm{C}++$ para sistemas operacionais compatíveis com Windows e com Unix. E é baseado em sistemas de janelas com barra principal de menus o que favorece a escolha e ativação das funções do sistema. A ativação deste software permite a interação com o usuário a partir da inserção dos parâmetros exigidos por cada função.

Todos os parâmetros inseridos pelo usuário no SPRING são previamente verificados com o intuito de alertar-lo de possível erro ou dados inválidos. As janelas contem ainda botões de executar e fechar facilitando a operacionalidade do software com o usuário no caso de desistência de determinada execução de função. 
O SPRING vem sendo utilizado em várias áreas de aplicação como a agricultura, manejo florestal, gestão ambiental, geografia, planejamento urbano e regional, oceanografia dentre outros. E seu desenvolvimento é de extrema importância para um país continental como o Brasil, pois traz o conhecimento, gerenciamento e possibilita o investimento nos problemas relacionados a sua geografia (FELGUEIRAS, 2006).

Segundo MOREIRA (2001) o SPRING é conhecido pelo conjunto significativo de projetos ambientais envolvidos como o levantamento dos remanescentes da Mata Atlântica Brasileira pela SOS Mata Atlântica (2003), a cartografia fito-ecológica de Fernando de Noronha realizada pelo NMA/EMBRAPA e o mapeamento das áreas de risco para plantio de toda a Região Sul do Brasil como culturas de milho, trigo e soja realizados pelo CPAC/EMBRAPA.

Podemos citar ainda, o estudo das características geológicas da bacia do Recôncavo com a integração de dados geofísicos, altimétricos e de SR conduzido pelo CENPES/Petrobrás e também estudos nas áreas agrícolas realizado por ASSAD e SANO (1993). 


\section{III - ÁREA DE ESTUDO}

A Terra não é estática, ela está em contínuas modificações ao longo do tempo, e por isso é importante o conhecimento de suas características ambientais e sociais. Os atributos físicos como a geologia, a geomorfologia, hidrografia, pedologia, cobertura vegetal entre outros devem ser tomados como um todo integrado pela força climática.

Os atributos sociais, no caso a sociedade, são ativos e sofrem influências do meio construído e modificado no espaço geográfico. Este espaço é dinâmico e os atributos que nele existem interagem de forma complexa nesse movimento determinando o próprio meio (MORAES, 2002).

Segundo DE MARTONNE (1953), precursor da geografia científica, o estudo de uma região se satisfaz quando se tem conhecimento do conjunto de todas as características ambientais e sociais do planeta Terra. Portanto, a Terra é tomada como um todo indissociável e suas características são elementos que se interrelacionam (SANTOS, 1985).

Desta forma, para o estudo do uso e cobertura da terra, o conhecimento das características ambientais e sociais é de grande representatividade. Pois, as mesmas objetivaram neste trabalho de pesquisa, numa visão integrada, dar subsídios para entender, utilizar e avaliar a sociedade em intercâmbio material com a natureza mediado pelo trabalho do homem.

\subsection{LOCALIZAÇÃO E SITUAÇÃO GEOGRÁFICA.}

CORRÊA (2003) diz que o espaço geográfico tem um conceito muito amplo e vago. Ele se refere a uma porção no planeta Terra correspondente pela natureza em conjunto com homem e também pela referencia de localização geográfica.

A área de estudo está localizada na região sudeste do Brasil entre os paralelos $19^{\circ} 30^{\prime}$ e $25^{\circ} 30^{\prime}$ sul e entre os meridianos $43^{\circ} 30^{\prime}$ e $54^{\circ} 00$ Oeste de Greenwich (FIGURA 26). O estado de São Paulo faz fronteira ao norte com Minas Gerais, ao nordeste com Rio de Janeiro e parte de Minas Gerais, a leste com o Oceano Atlântico com aproximadamente 622 km de costa marítima, a oeste com o estado de Mato Grosso do Sul e ao sul com o Paraná. 


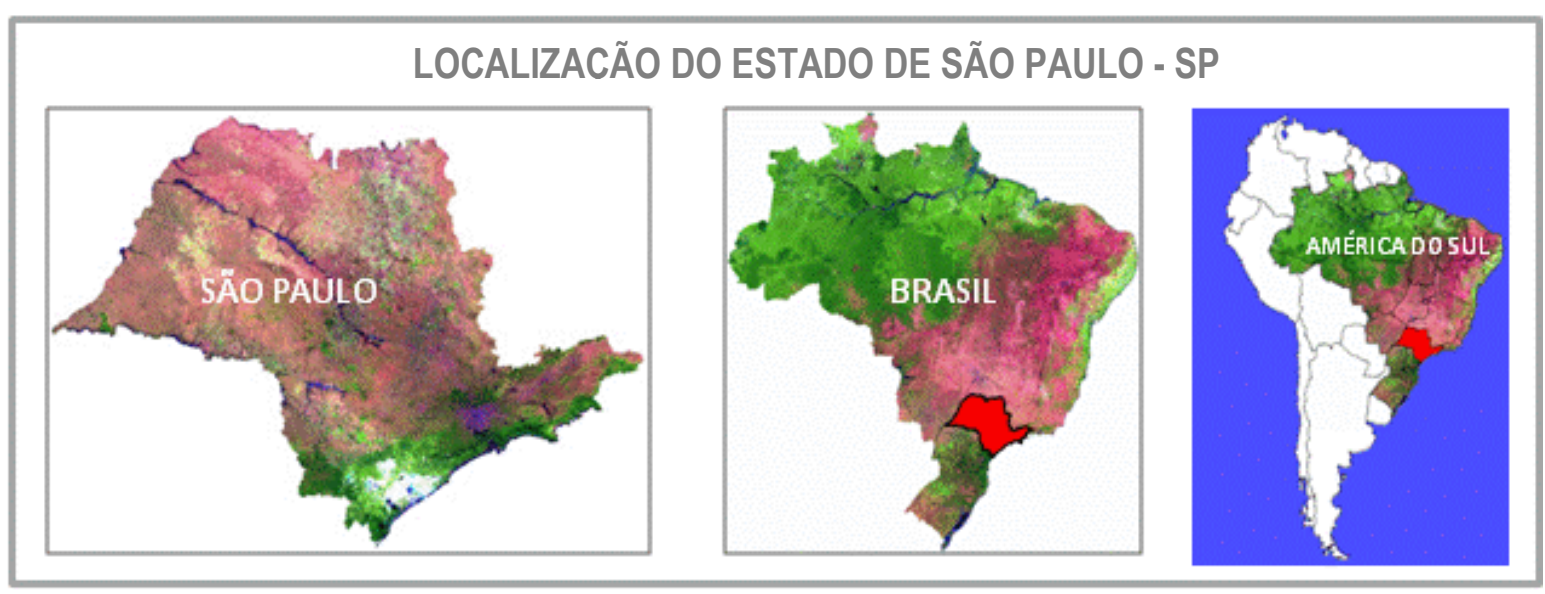

FIGURA 26 - Localização do estado de São Paulo.

O estado possui 645 municípios distribuídos num território de 248.209,426 km² e suas principais cidades, sede municipais, são: São Paulo (capital), Campinas, Guarulhos, Santo André, Osasco, São Bernardo do Campo, São José dos Campos, Araraquara, Ribeirão Preto, Santos, Sorocaba, Diadema e Jundiaí. (FIGURA 27). E seus principais rios são: Tietê, Paranapanema, Grande, Turvo, Pardo, do Peixe, Paraíba do Sul e Piracicaba (FIGURA 28).

São Paulo é o estado com a maior população do Brasil. Conta com mais de 40 milhões de habitantes, é a terceira unidade administrativa mais populosa da América do Sul. Ele possui o maior parque industrial, logo a maior produção econômica com mais de $31 \%$ do PIB do país (SÃO PAULO, 2010).

A população é a mais diversificada do Brasil compreendida por descendentes de imigrantes de italianos e portugueses, mas existe grande influência de ameríndios e africanos e por outras migrações, como árabes, alemães, espanhóis e japoneses. Segundo registros da imigração são cerca de 3 milhões pessoas vindas de diferentes estados e países, o que aufere ao estado o mais cosmopolita da America do Sul.

A construção do estado de São Paulo teve a colaboração de povos de todas as partes do Brasil e do mundo, ele detém da melhor infra-estrutura e mão-de-obra qualificada. O estado possui grandes indústrias e ainda é produtor de alta tecnologia. Dentre todos os estado do Brasil é o mais rico e tem alto Índice de Desenvolvimento Humano (IDH) superado apenas por Santa Catarina e pelo Distrito Federal. 


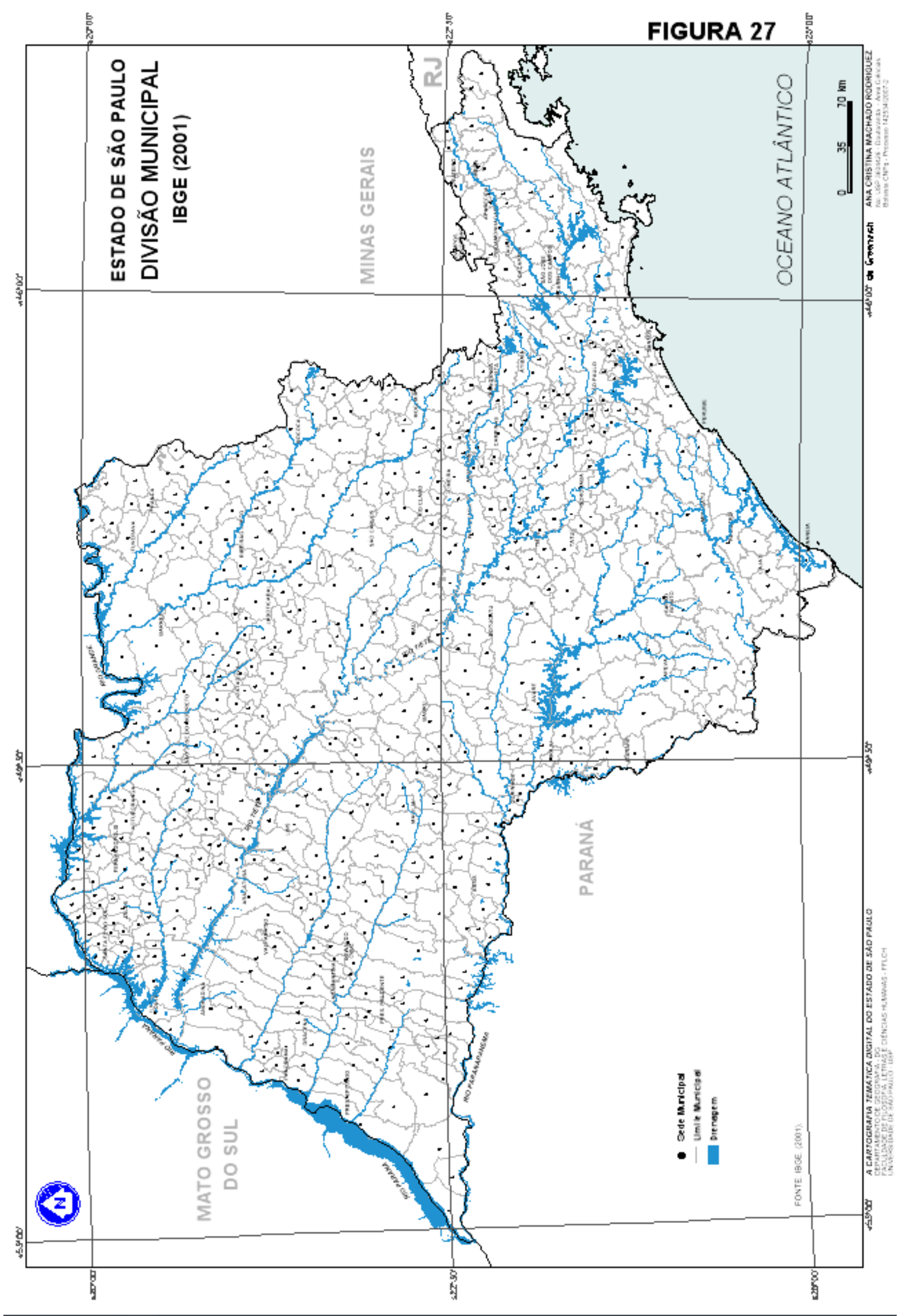




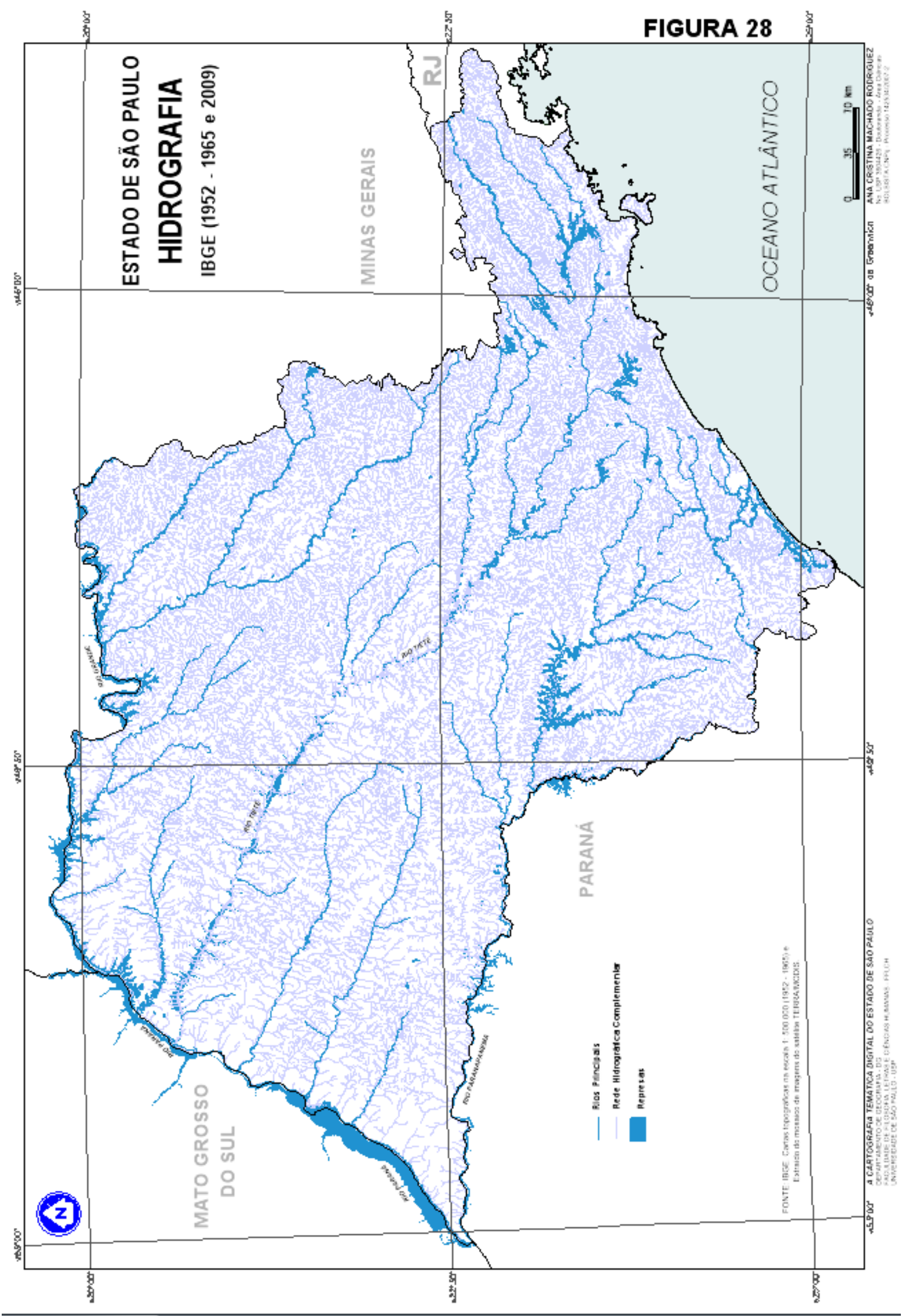




\subsection{CARACTERÍSTICAS AMBIENTAIS}

\subsubsection{GEOLOGIA}

O estudo da geologia é essencial para o conhecimento das distintas fases da história física da Terra, assim como sua composição, estrutura, propriedades físicas, evolução e os processos que lhe dão forma.

A geologia do estado de São Paulo está dividida nas seguintes unidades litoestratigráficas (IPT, 1981) (FIGURA 29):

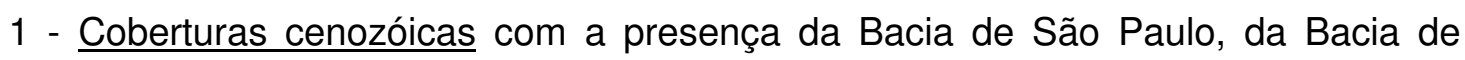
Taubaté e Coberturas terciárias;

2 - Bacia do Paraná e Vulcanismo Mesozóico apresentando as sequências sedimentares do Grupo Bauru, Formação Caiuá Grupo São Bento (Derrames de basalto), Grupo Passa Dois, Grupo Tubarão e Grupo Paraná;

3 - Embasamento Pré-Cambriano e Eopaleozóico com os Corpos alcalinos, Epimetamorfitos da formação Eleutério, Proterozóicos (superior, médio e inferior) e Arqueano.

Os depósitos terciários da Bacia de São Paulo que abrangem sedimentos referidos às formações São Paulo e Itaquaquecetuba representam um conjunto sedimentar paleogeno que inclui um sistema basal de leques aluviais e canais entrelaçados, sistema lacustre (em parte sincrônico com os anteriores) e sistema fluvial meandrante de topo.

A Bacia de Taubaté é uma depressão alongada na direção SW/NE e encravada entre as Serras do Mar e da Mantiqueira. Ela tem o mais espesso registro sedimentar aluvial-lacustre do Oligoceno quando comparado com as bacias menores que compõem o denominado Sistema de Riftes da Serra do Mar.

O estado de São Paulo tem a maior parte de seu território localizado na Bacia do Paraná. E a evolução geológica desta é resultado de vários processos estruturais e tectônicos que se manifestaram por arqueamentos, flexuras e alinhamentos do embasamento assumindo um comportamento ora marginal, ora transversal à bacia, ou ainda constituindo altos e embaciamentos internos.

RICCOMINI (1991) completa que esse fato contribuiu para os processos de compartimentação e sedimentação da bacia, influenciando no comportamento do substrato basáltico que veio a acomodar os sedimentos cretáceos Bauru. 
Os sedimentos do Grupo Bauru localizam-se discordantemente sobre os basaltos da Formação Serra Geral e segundo DAEE (1990) a mesma ocupa 47\% do estado de São Paulo. O Grupo Bauru é composto por unidades suprabasálticas cretáceas e estas estão arranjadas em duas versões de divisão estratigráfica.

Na proposta clássica de subdivisão estratigráfica dos sedimentos do Grupo Bauru elaborada por SOARES et al. (1980) elevou-se a Unidade Bauru à categoria de Grupo e o subdividiram nas formações Caiuá, Santo Anastácio, Adamantina e Marília.

No estado de São Paulo a formação que se apresenta é a Caiuá e esta ocorre de forma progressiva e transicional progredindo tanto vertical como lateralmente. Os sedimentos presentes nesta formação são depositados em ambiente fluvial, afloram em pequena extensão na região do Pontal do Paranapanema e nas proximidades do Rio Paraná (RICCOMINI, 1991).

Os depósitos vulcano-sedimentares do Grupo São Bento pertencente à idade triássicocretácea é se subdvidide em dois grandes pacotes de natureza distintas. Estratigraficamente posicionados abaixo se encontram os sedimentos fluvio-eólicos pertencentes às Formações Pirambóia e Botucatu.

Acima, e em discordância com estes sedimentos, encontram-se os derrames vulcânicos da Formação Serra Geral. Nos estados de São Paulo e Minas Gerais, este pacote vulcano-sedimentar assenta-se discordantemente sobre os depósitos do Grupo Passa Dois. (PETRI \& FÚLFARO, 1983).

O Grupo Passa Dois foi formado durante o Permiano e tem sua distribuição cronoestratigráfica decrescente. Neste grupo existe a presença de calcários, folhelhos e fósseis, a mesma é ainda dividida nas formações Irati e Corumbataí localizadas no centro leste do estado de São Paulo.

No Grupo Tubarão são registradas rochas que servem para lajes da região de Piracicaba e Itu. Ele é constituído de uma associação heterogênea de rochas clásticas, inclusive carvão, o qual é explorado na parte superior do Subgrupo Itararé.

A ocorrência deste grupo se evidencia desde o Uruguai até Goiás e é clara a sua presença em certas localidades depositada diretamente sobre o Pré-Cambriano. 


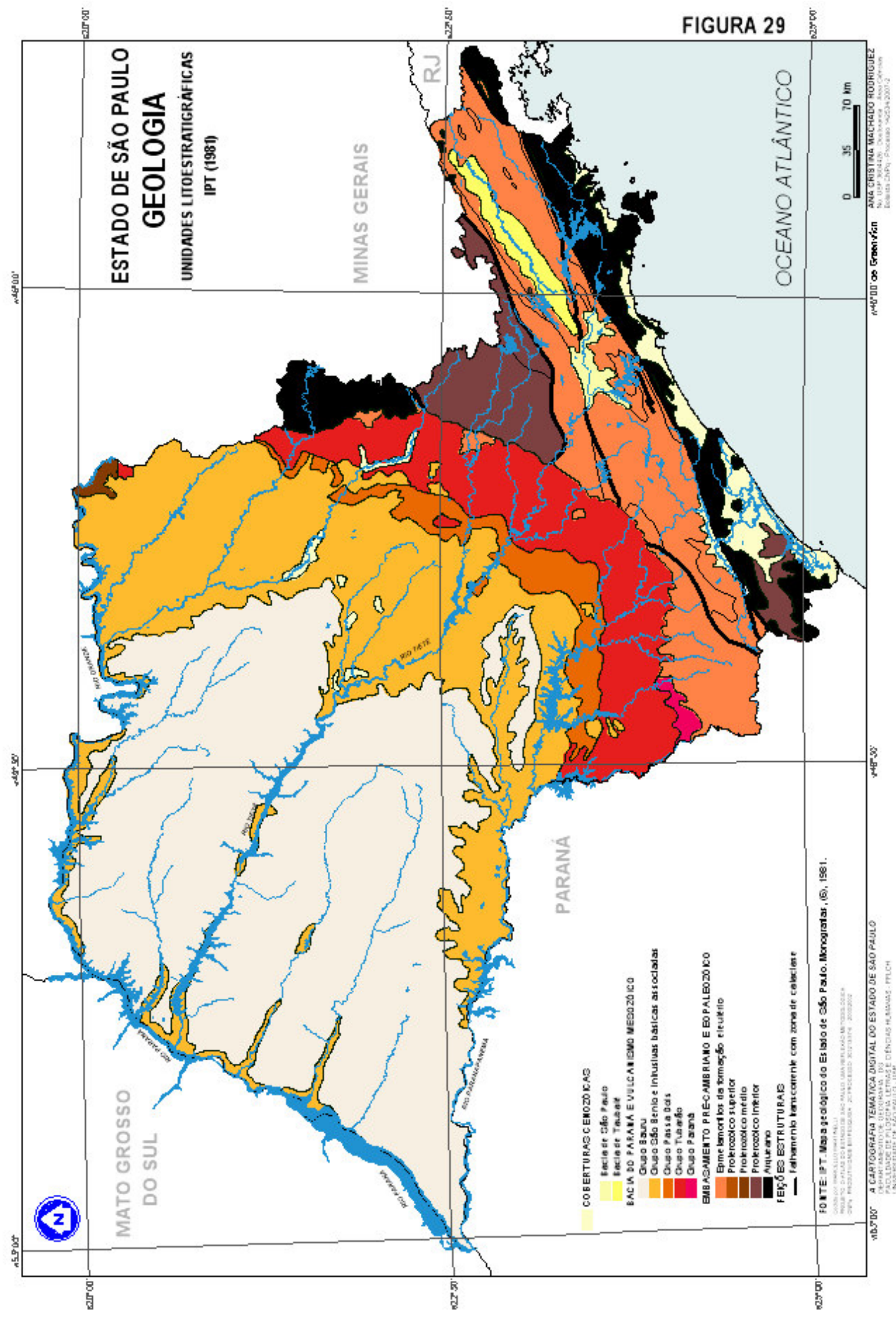




\subsubsection{GEOMORFOLOGIA}

O conhecimento da geomorfologia de uma região é indispensável, pois nos permite inferir os processos morfogenéticos atuantes em seu âmbito e assim nos possibilita analisar a distribuição espacial das formas topográficas e dos depósitos sedimentares.

Para MARTINELLI (2009) um mapa de geomorfologia tem por objeto a representação qualitativa, quantitativa e explicativa das formas do relevo. E este é o resultado da oposição entre forças endógenas (internas) e exógenas (externas) assinaladas pela escala do tempo geológico (CASSETI, 1991).

As divisões elaboradas por ALMEIDA (1964) ajudaram no primeiro mapeamento sistemático do relevo do estado de São Paulo organizado por PONÇANO (1981). Onde, os mesmos a partir da metodologia desenvolvida pelo "Commnonwealth Scientific and Industrial Research Organization - CSIRO" identificaram as regiões no estado por padrões recorrentes de topografia, solos e vegetação para a construção de um mapa síntese contendo os padrões morfológicos do relevo.

Os autores elaboram o mapa geomorfológico pela utilização do raciocínio de síntese, o qual excluía o registro exaustivo dos elementos constituintes transformando-os em uma fusão de tipos. Assim, os elementos eram identificados e delimitados formando conjuntos espaciais que agrupavam lugares, regiões ou áreas unitárias de análise caracterizadas por agrupamentos de atributos ou variáveis (MARTINELLI, 2009).

ALMEIDA (1964) identificou as províncias geomorfológicas do estado, onde as subdivisões de zonas referiam-se aos sistemas de relevo e as subzonas as suas unidades. O estado se dividia em cinco províncias geomorfológicas: Planalto Atlântico, Província Costeira, Depressão Periférica, Cuestas Basálticas e Planalto Ocidental (FIGURA 30).

O Planalto Atlântico compreende a faixa de rochas cristalinas que vai da região sul do estado (Guapiara) até a região nordeste, na divisa com o Estado de Minas Gerais (Campos do Jordão). A Província costeira inclui as baixadas litorâneas, as serras da costa (Serra do Mar, de Paranapiacaba e de Itatins) e os morros da costa e do Vale do Ribeira.

A Depressão periférica abrange a região que se estende desde o Planalto Atlântico para o oeste paulista, pelos vales do Médio Tietê, Paranpanema e Mogi-Guaçu. As Cuestas basálticas são formadas pelos remanescentes erosivos das camadas de rochas vulcânicas basáltica da Bacia do Paraná, na faixa que vai desde Ituverava e Franca a nordeste, até Botucatu e Avaré a sudoeste. E o Planalto ocidental que inclui os planaltos das regiões de Marília, Catanduva e Monte Alto. 


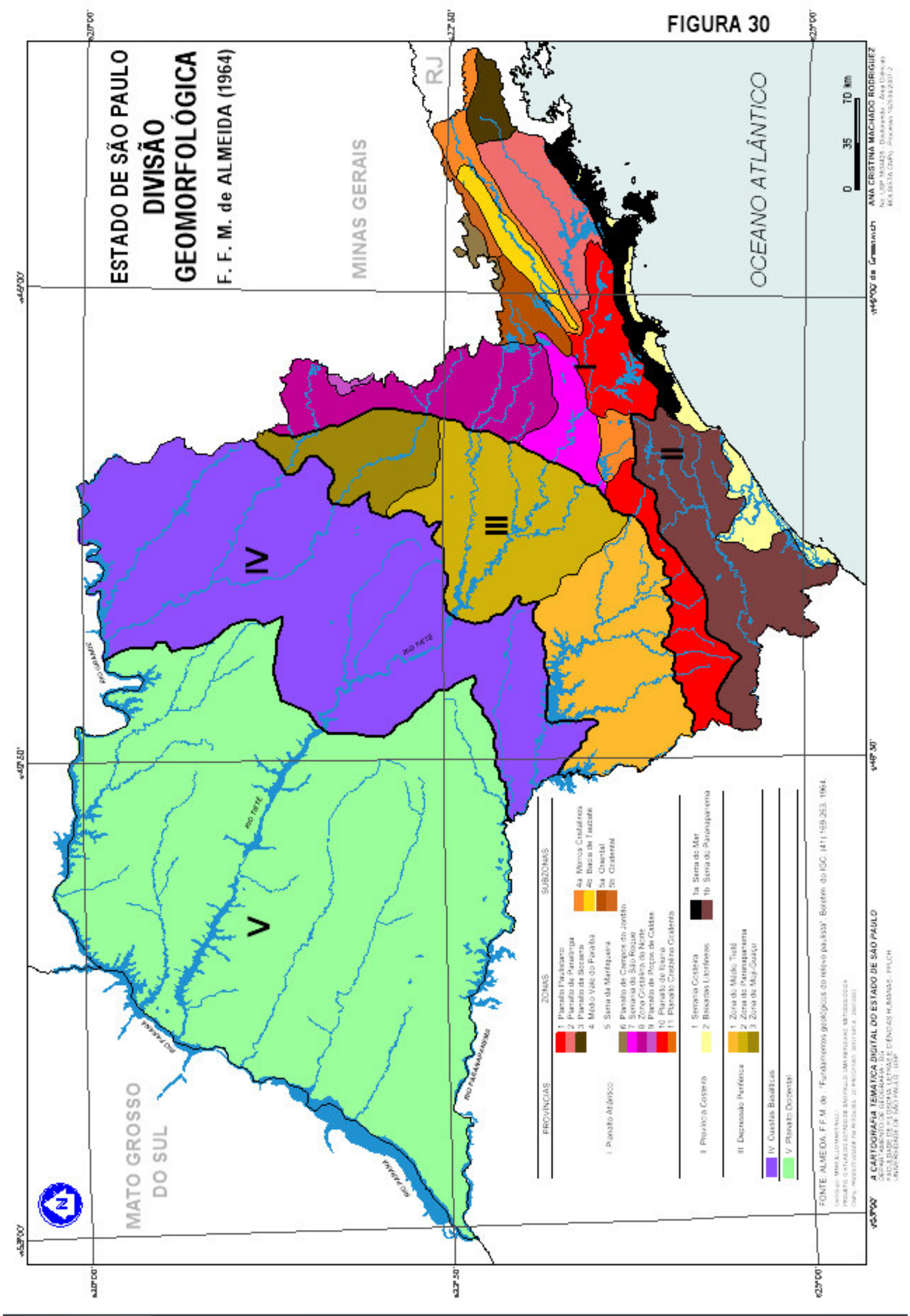


ALMEIDA (1981) relata que as tentativas para subdividir o relevo se iniciaram com MORAES REGO (1932). E logo depois se destacaram também, DEFFONTAINES (1935), MONBEIG (1949) e AB'SÁBER (1956) entre outros.

ROSS \& MOROZ (1997) elaboraram a macrocompartimentação do relevo do estado baseando-se pelo critério morfoclimático da classificação de AB'SÁBER associando a esta a estrutura geológica e a ação dos agentes externos do relevo (passado e presente). Eles consideraram que cada unidade geomorfológica de grande dimensão se difere na paisagem por suas características fisionômicas (morfologia), gênese e idade.

Os autores traçaram um embasamento teórico-metodológico no entendimento da gênese das formas do relevo terrestre a partir de conceitos de morfoestrutura e morfoescultura. Para a classificação das formas do relevo em morfoestrutural (estrutura geológica), morfoescultural (ação de agentes externos) e morfoclimática (clima e o relevo) foram criados também táxons que destacavam:

1) a forma de relevo (planalto, planície e depressão), 2) a estrutura geológica de onde os planaltos foram modelados (bacias sedimentares, núcleos cristalinos arqueados, cinturões orogênicos e coberturas sedimentares sobre o embasamento cristalino) e 3) as unidades morfoesculturais (planalto, planície e depressão) utilizando nomes locais e regionais de uma determinada área.

Segundo o IBGE (2005) a partir desta classificação existem (FIGURA 31):

- as morfoestruturas de depósito sedimentares inconsolidados Terciários e ou Quaternários;

- as morfoestruturas de bacias e coberturas sedimentares por Bacias e coberturas sedimentares litorâneas e por Bacia sedimentar do Paraná;

- as morfoestruturas de faixa de dobramentos e coberturas metassedimentares associadas por Faixas de dobramentos do Sudeste/Sul;

- as morfoestruturas de embasamento em estilos complexos por Embasamentos do Sudeste/Sul.

A classificação mencionada é uma síntese dos principais compartimentos classificados segundo os critérios de similitude de formas, altimetria relativa e gênese, ordenados em Domínios morfoestruturais, sob efeito de processos climáticos subatuais e atuais conforme IBGE (2005) apud MARTINELLI (2009). 


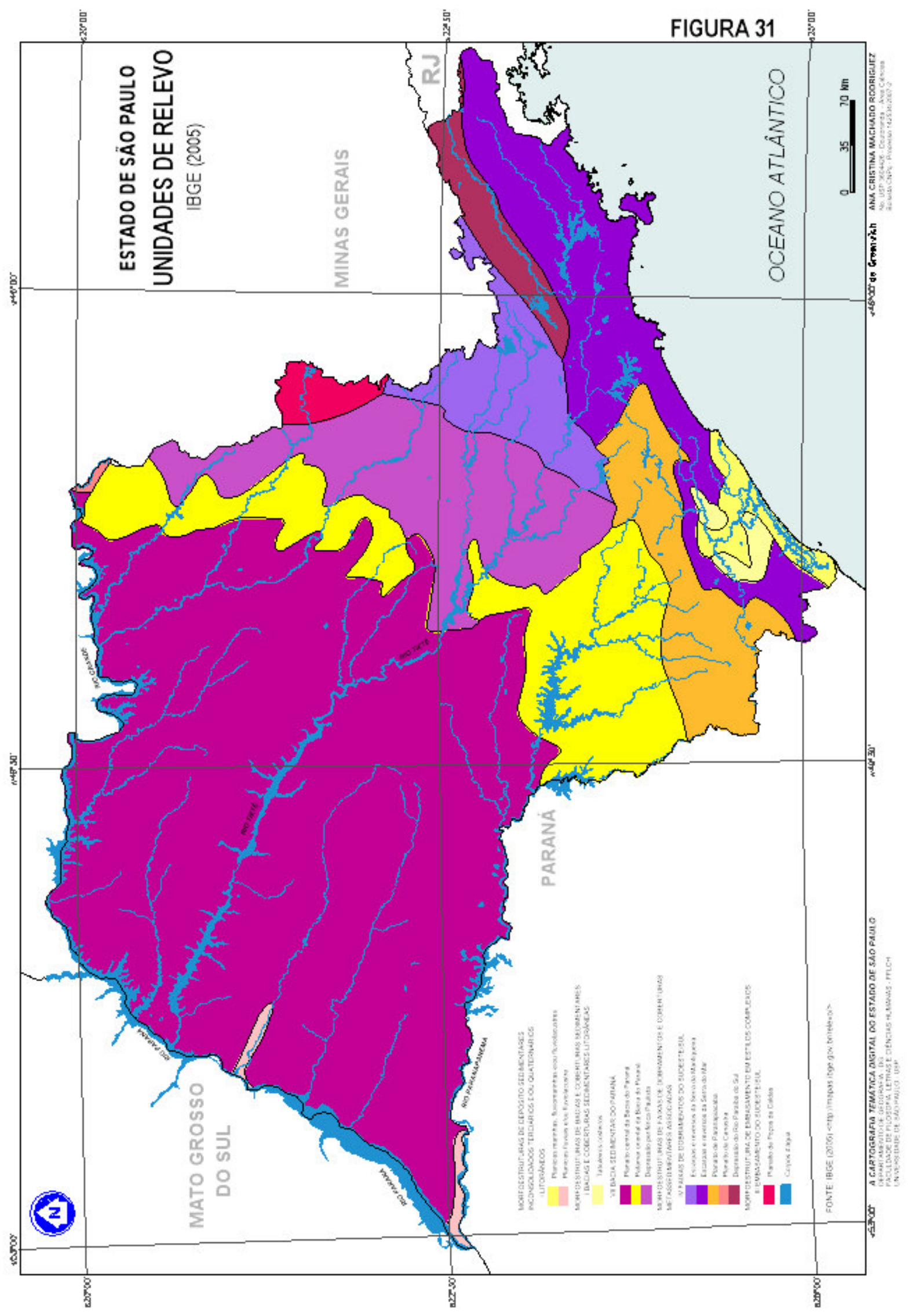




\subsubsection{HIDROGRAFIA}

A Bacia do estado de São Paulo mais importante é a do Rio Paraná que comporta grande potencial hidrelétrico da região e é claro de energia produzida. A produção de energia é favorecida pela existência de várias quedas d’água resultado de um perfil longitudinal acidentado. Nesta encontram-se instaladas as usinas de Itaipu, Furnas, Porto Primavera entre outras (AMBIENTE BRASIL, 2006).

O Rio Paraná é o principal curso d'água desta bacia e nele seus afluentes são os rios Grande, Paranaíba, Tietê, Paranapanema, Iguaçu dentre outros. Esse rio passa por todo o eixo central da Bacia do Paraná e possui uma área de 1,5 milhões de $\mathrm{km}^{2}$ situa-se na porção centro-leste da America do Sul abrangendo o nordeste da Argentina, o centrosul do Brasil, a porção leste do Paraguai e o norte do Uruguai.

Segundo a classificação do IGC (1985) existem cinco bacias no estado de São Paulo: Litoral compreendido pelo Ribeira de lguape e Bacias menores, Paraíba do sul, Paraná incluindo o Tietê, Peixe, Aguapeí, São José dos dourados e as bacias menores, Grande contando com Turvo, Pardo e as bacias menores e finalmente Paranapanema (FIGURA 32).

Existem 15 (quinze) barragens com construções de Usinas Hidrelétricas - UEH no estado de São Paulo (TABELA 13). Estas instalações abrigam grandes tubos inclinados que possuem turbinas e geradores que propiciam a geração de energia elétrica para todo o estado.

TABELA 13 - Relação das barragens do estado de São Paulo.

\begin{tabular}{l|l|l|r|r}
\hline \multicolumn{1}{c|}{ BARRAGENS } & \multicolumn{1}{|c|}{ LOCALIZAÇÃO } & \multicolumn{1}{|c|}{ MUNICÍPIO } & $\mathbf{k m}^{2}$ & $\mathbf{k m}^{3}$ \\
\hline UEH ROSANA (PR-SP) & $\begin{array}{l}\text { Rio Paranapanema, Bacia do } \\
\text { Rio Paraná }\end{array}$ & DIAMANTE DO NORTE - PR & 217 & 1.920 \\
\hline $\begin{array}{l}\text { UEH ÁGUA } \\
\text { VERMELHRA ( SP) }\end{array}$ & $\begin{array}{l}\text { Rio Grande, Bacia do Rio } \\
\text { Paraná }\end{array}$ & INDIAPORÃ - SP & 647 & 11.025 \\
\hline UEH DE BARIRI (SP) & Rio Tietê, Bacia do Rio Paraná & BARIRI - SP & 62,58 & 542 \\
\hline $\begin{array}{l}\text { UEH DE BARRA } \\
\text { BONITA (SP) }\end{array}$ & Rio Tietê, Bacia do Rio Paraná & BARRA BONITA - SP & 308 & 2.566 \\
\hline $\begin{array}{l}\text { UEH MARIMBONDO } \\
\text { (SP) }\end{array}$ & $\begin{array}{l}\text { Rio Grande, Bacia do Rio } \\
\text { Grande }\end{array}$ & FRONTEIRA - SP & 438 & 6.150 \\
\hline UEH CAPIVARA (SP) & $\begin{array}{l}\text { Rio Paranapanema, Bacia do } \\
\text { Rio Paraná }\end{array}$ & TACIBA - SP & 515 & 10.540 \\
\hline UEH CACONDE (SP) & Rio Pardo, Bacia do Rio Paraná & CACONDE - SP & 31,12 & 555 \\
\hline UEH IBITINGA (SP) & Rio Tietê, Bacia do Rio Paraná & IBITINGA - SP & 113,2 & 981 \\
\hline $\begin{array}{l}\text { UEH ILHA SOLTEIRA } \\
\text { (SP) }\end{array}$ & $\begin{array}{l}\text { Rio Paraná, Bacia do Rio } \\
\text { Paraná }\end{array}$ & ILHA SOLTEIRA - SP & 1.200 & 21.060 \\
\hline UEH JAGUARI (SP) & $\begin{array}{l}\text { Rio Jaguari, Bacia do Atlântico } \\
\text { Sul (trecho leste) }\end{array}$ & JACAREÍ - SP & 55 & 1.236 \\
\hline \hline
\end{tabular}




\begin{tabular}{l|l|l|r|r}
\hline \hline $\begin{array}{l}\text { UEH NOVA } \\
\text { AVANHANDAVA (SP) }\end{array}$ & Rio Tietê, Bacia do Rio Paraná & BURITAMA - SP & 210 & 2720 \\
\hline $\begin{array}{l}\text { UEH PORTO } \\
\text { PRIMAVERA (SP) }\end{array}$ & $\begin{array}{l}\text { Rio Paraná, Bacia do Rio } \\
\text { Paraná }\end{array}$ & ROSANA - SP & 2.250 & 20.000 \\
\hline UEH PROMISSÃO (SP) & Rio Tietê, Bacia do Rio Paraná & PROMISSÃO - SP & 530 & 7.408 \\
\hline $\begin{array}{l}\text { UEH COLÔMBIA (SP- } \\
\text { MG) }\end{array}$ & $\begin{array}{l}\text { Rio Grande, Bacia do Rio } \\
\text { Grande }\end{array}$ & GUAÍRA - MG & 140 & 1.524 \\
\hline $\begin{array}{l}\text { UEEH VOLTA GRANDE } \\
\text { (SP) }\end{array}$ & $\begin{array}{l}\text { Rio Grande, Bacia do Rio } \\
\text { Paraná }\end{array}$ & MIGUELÓPOLIS - SP & - & - \\
\hline \hline
\end{tabular}

FONTE: MINISTÉRIO DOS TRANSPORTES (2006). 


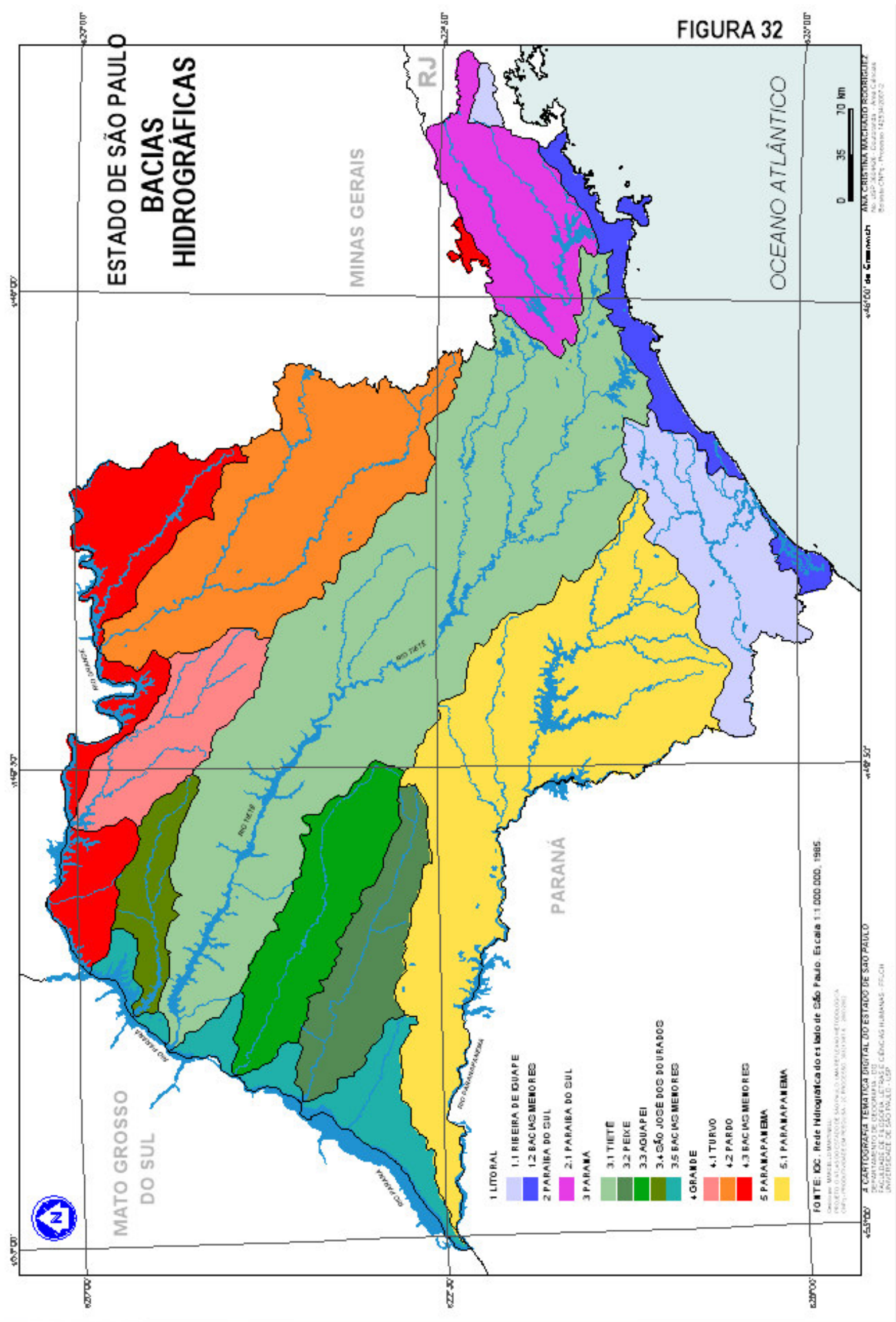




\subsubsection{CLIMA}

A primeira classificação de âmbito mundial a ser proposta foi a de KÖPPEN em 1918. A mesma envolvia parâmetros empíricos desenvolvidos a partir dos valores médios anuais ou mensais de temperatura e precipitação. MARTINELLI (2010) comenta que essa classificação (modo estático) não levava em conta causas como, pressão, ventos, massas de ar, frentes ou tempestades.

Segundo a CEPAGRI (2006) a partir da classificação climática de Koppën existem cerca de sete tipos climáticos diferentes que se resumem de forma evidente ao clima úmido. Mas, de acordo com o relevo existem só quatro tipos climáticos são mais evidentes: o Tropical Super-Úmido, o Tropical de Altitude, o Tropical Quente e Úmido e também o Sub Tropical Úmido.

O Tropical Super-Úmido (Aw) ocorre na baixada litorânea e encostas da Serra do Mar com temperaturas oscilantes entre 20 e $22^{\circ} \mathrm{C}$ com chuvas abundantes, principalmente em Santos (Itapanhaú), onde é registrado o mais alto índice de chuvas do país (4.154 $\mathrm{mm} / \mathrm{ano})$.

O Tropical de Altitude (Cwa) onde a maior parte do planalto está localizada neste tipo climático que é caracterizado por invernos secos e verões chuvosos apresentando temperaturas médias que podem ultrapassar a $20^{\circ} \mathrm{C}$. Enquanto que em regiões montanhosas a temperatura pode cair até $14^{\circ} \mathrm{C}$ como é o caso dos Maciços de Itatiaia e Campos do Jordão.

O Tropical Quente e Úmido (As) que é naturalmente encontrado na região noroeste do estado apresenta temperaturas registradas em 24ํㅜ (próximos dos rios Grande e Paraná) podendo diminuir ou aumentar de acordo com suas respectivas altitudes. $O$ índice pluviométrico é bastante variável entre 1.000 e 1.250 mm/ano.

E o Subtropical Úmido (Cfa) predominante da região sul Estado apresenta temperaturas entre 18 e $20^{\circ} \mathrm{C}$. Os verões são quentes e as chuvas bem distribuídas apresentando um índice pluviométrico de $1.500 \mathrm{~mm} / \mathrm{ano}$.

No entanto, MONTEIRO (1973) se baseando na dinâmica continental atmosférica vista por mecanismos de circulação ao nível continental conseguiu classificar os climas, expondo-os em um mapa de síntese, o da tipologia climática para o estado de São Paulo.

Nos mecanismos da circulação atmosférica, agora no âmbito regional, o autor indicou dois níveis: o de classificação climática e outro incluindo os fatores geomorfológicos com e sem a presença de período seco (FIGURA 33) (MARTINELLI, 2010) 


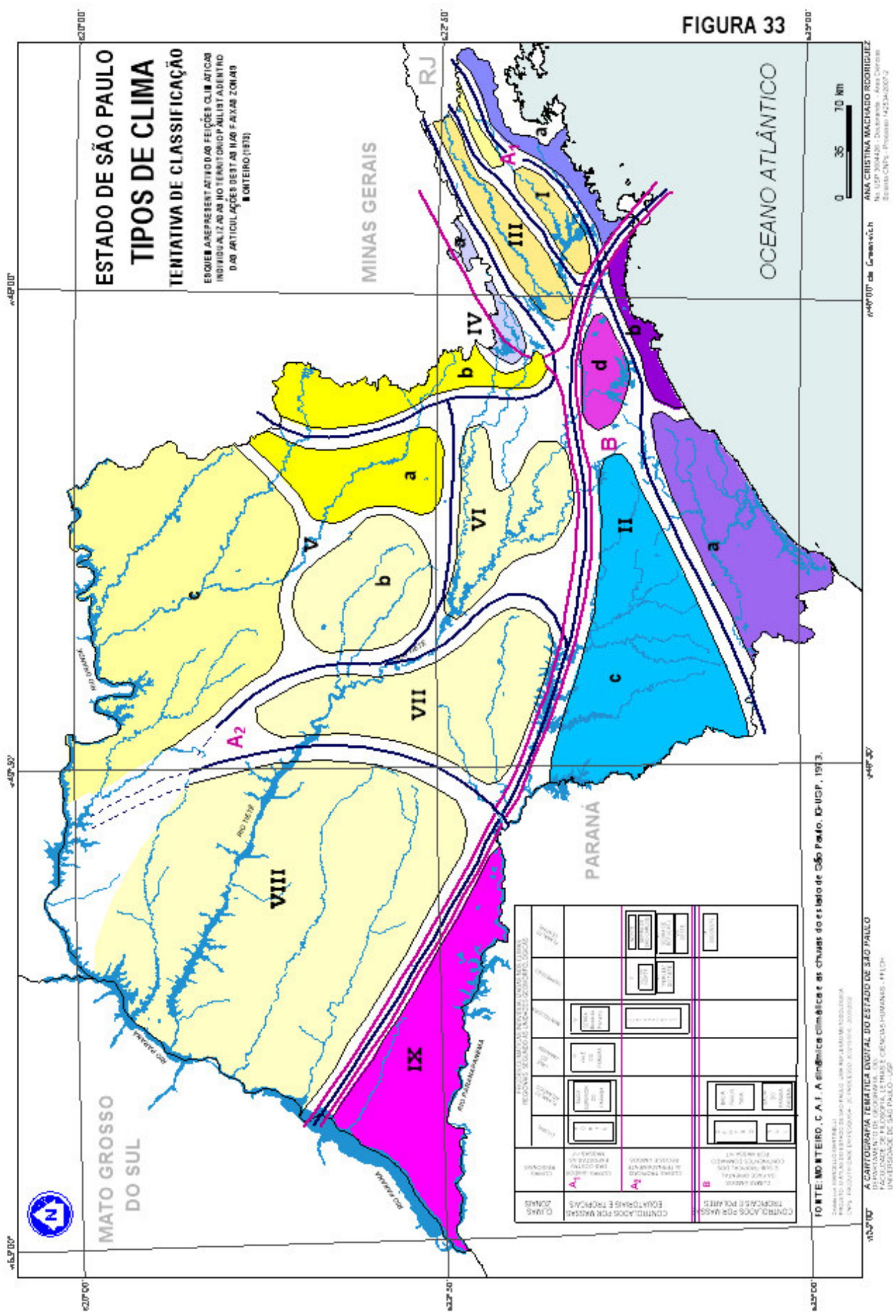


O primeiro traçaria um limite zonal por conta da co-participação das características do sul brasileiro (dotada de acentuada amplitude térmica, da incidência de sistemas meteorológicos contrastantes e farta pluviosidade no ano todo), do centro-oeste e sudeste contendo características peculiares de período seco.

No segundo, os níveis taxonômicos inferiores as subdivisões serão impostas por conta da influência da organização ecológica e da ação antrópica. Assim, a legenda foi organizada num quadro de dupla entrada com os três níveis de organização, a saber:

a) Climas zonais controlados por massas equatoriais e tropicais e climas controlados por massas tropicais e polares;

b) Climas regionais e climas úmidos das costas expostas às massas tropicais marítimas, climas tropicais alternadamente secos e úmidos e climas úmidos da face oriental e subtropical do continente dominada por massa tropical marítima; e

c) Feições climáticas individualizadas nos climas regionais, segundo as unidades atinentes ao Planalto Ocidental.

\subsubsection{PEDOLOGIA}

Os solos neste estado são formados em virtude de uma zona de transição entre as regiões de clima semi-árido e úmido situada ao norte de Minas Gerais, e também pela diversidade de relevo, vegetação e material de origem (LEPSCH, 2002).

Os solos existentes são classificados na classe dos Latossolos e dos Argissolos. Os Latossolos encontram-se basicamente em grande parte na região norte, leste e no centro do Estado, apresentando algumas consideráveis machas de Neossolos.

Os Neossolos estão presentes nas faixas litorâneas mais especificamente nas areias da orla costeira, remanescentes de antigas praias e dunas. E por vezes também são encontrados em partes serranas de declives excessivamente fortes impedindo um bom desenvolvimento dos solos (LEPSCH, 2002).

Já ao sul existe a predominância dos solos Argissolos, Latossolos e Cambissolos. Os Latossolos em algumas áreas são cobertos por cerrados se assemelhando ao Planalto Central.

Os Argissolos estão presentes em espaços com relevo do tipo mamelonar que são chamados de "mar de morros". Os mesmos são predominantes ainda no oeste do Estado, onde existe uma grande mancha de Latossolos localizada nos municípios de Araçatuba, Promissão e Penápolis (FIGURA 34) (OLIVEIRA et al., 1999). 


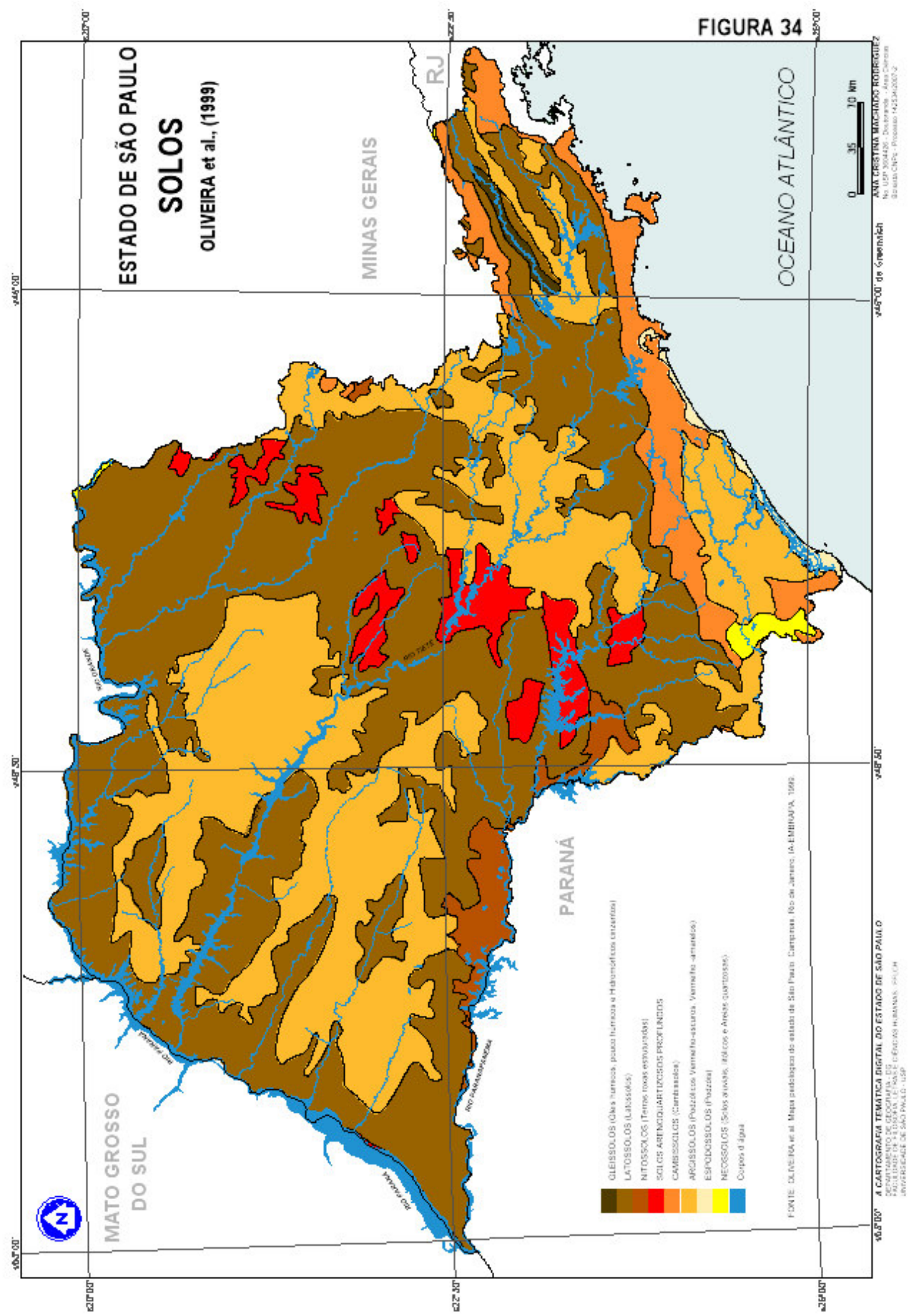


Segundo LEPSCH (2002) os solos Argissolos limitam a utilização para a agricultura devida sua topografia montanhosa, o que dificulta o trabalho com máquinas agrícolas gerando possíveis erosões. O que seria mais adequado nestas áreas seriam as culturas perenes, pastagens e reflorestamento.

Estes solos estão presentes ainda nos contrafortes das Serras do Mar e da Mantiqueira cobertos pela Mata Atlântica, a qual deveria estar sendo preservado, o que infelizmente, não vem ocorrendo nos últimos anos.

Existem ainda algumas áreas cobertas por florestas primitivas com a predominância de solos férteis, as chamadas "terras roxas", os quais estão presentes nos vales dos rios Parnaíba, Grande e Paranapanema, e em grande parte da região oeste de São Paulo.

\subsubsection{COBERTURA VEGETAL}

Segundo TROPPMAIR (1969) no estado de São Paulo a cobertura vegetal primitiva existente era Mata, Cerrados, Campos Limpos, Vegetação Litorânea, Vegetação de Araucária, Vegetação de Transição (Campo sujo), Ocorrências de áreas isoladas de Araucária e Predominância de Palmeiras (FIGURA 35).

$\mathrm{Na}$ classificação do RADAM (1981) foram descritas entorno de 10 classes da cobertura vegetal, a saber: Floresta Estacional Semidecidual (Vegetação secundária e Atividades agrícolas), Cerrado, Floresta Ombrófila densa (Vegetação secundária e Atividades agrícolas), Áreas de tensão ecológica (Atividades agrícolas), Florestas Ombrófila densa (Terras baixas), Floresta Ombrófila decidual (Submontana), Floresta Ombrófila mista (Vegetação secundaria e atividades agrícolas), Floresta Ombrófila densa (Montana), Floresta Ombrófila mista (Montana) e Áreas de tensão ecológica (Contato) (FIGURA 36). 


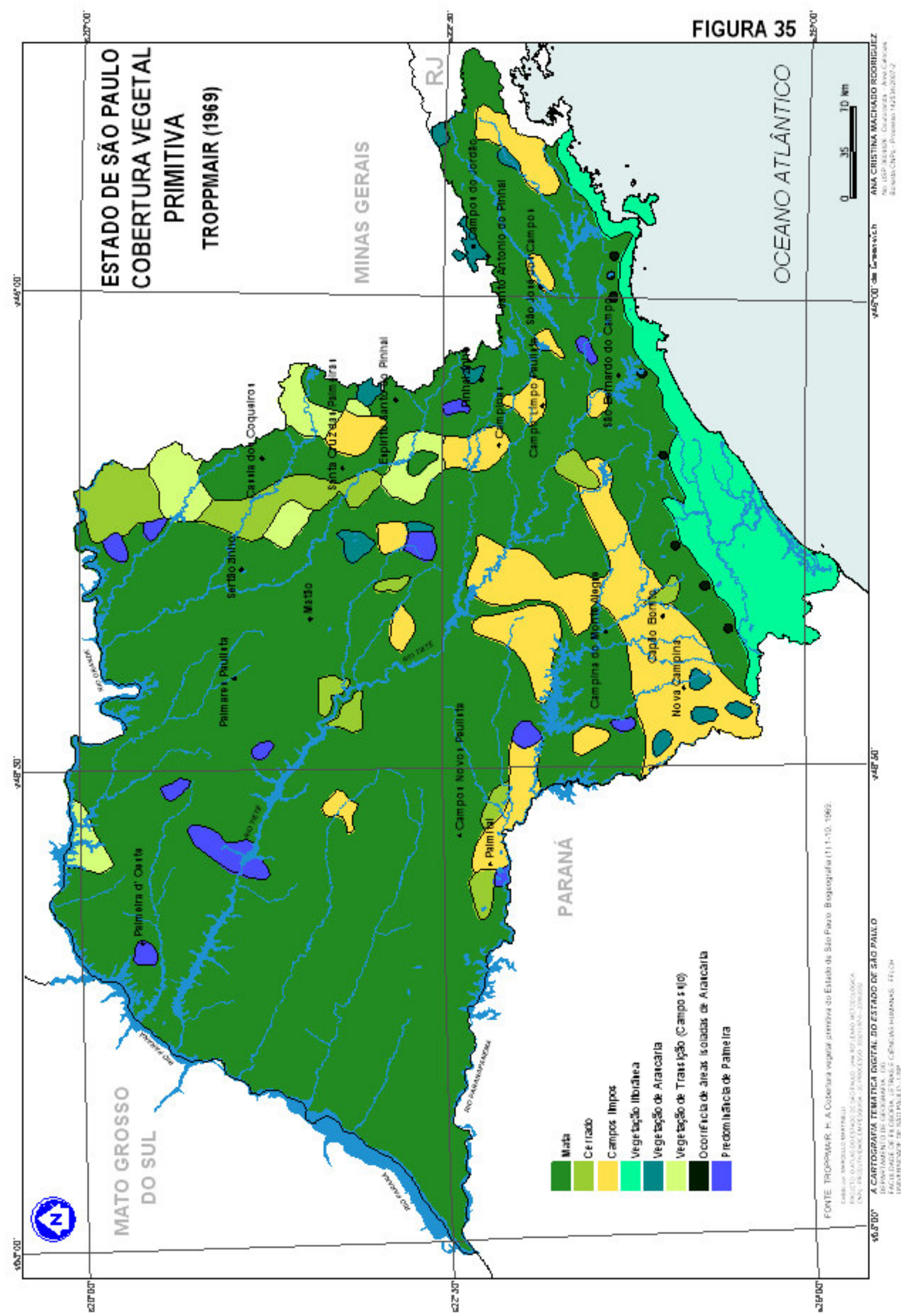




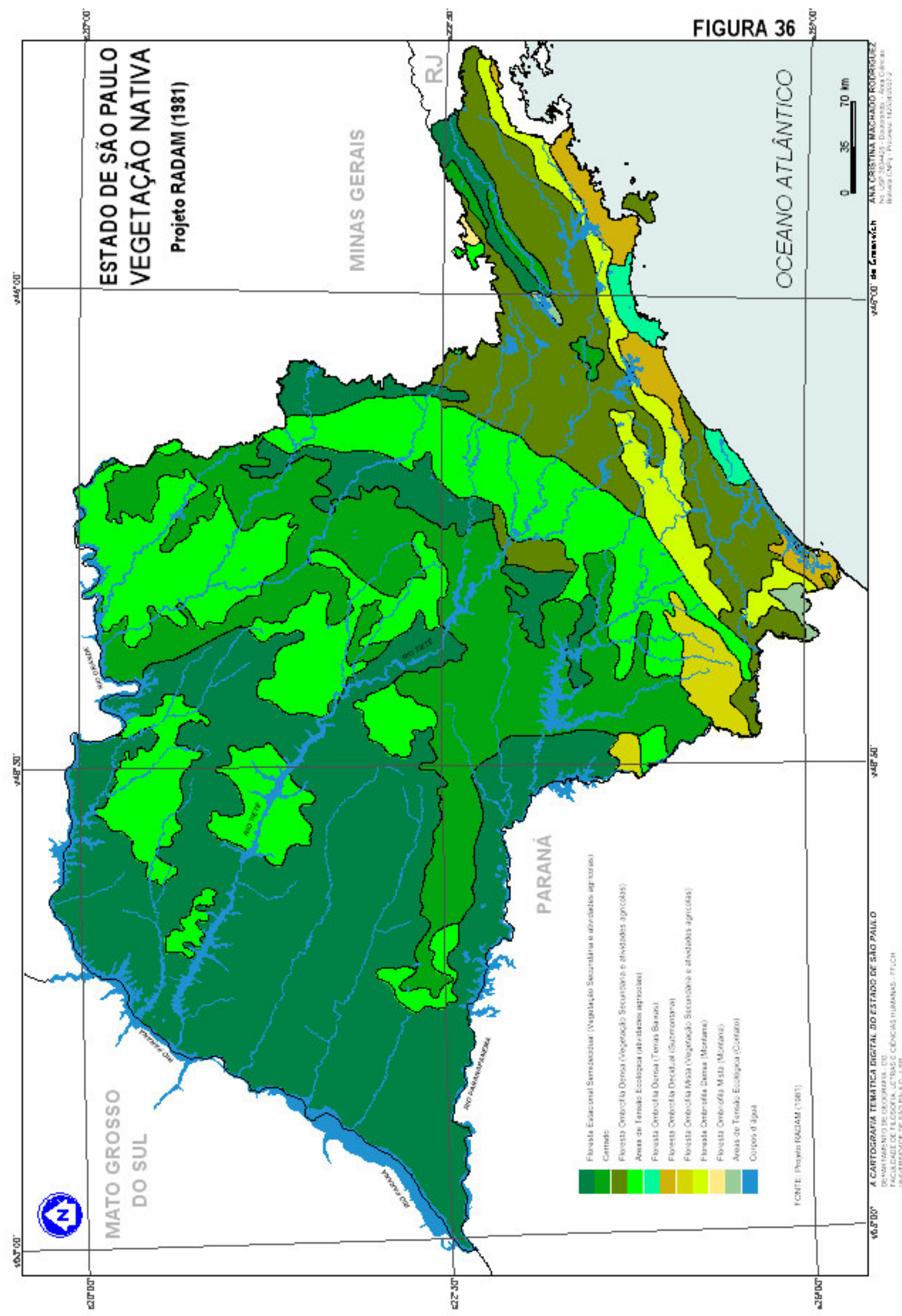


Os mapeamentos realizados por estes autores revelaram que cerca de $70 \%$ do estado de São Paulo era coberto por florestas. Hoje, depois de quase quatro décadas, o estado se encontra com menos de $82 \%$ do território coberto por florestas. $\mathrm{E}$ os remanescentes que ainda existem vêm sendo gradativamente devastados cedendo lugar para campos de cultivo ou ocupação urbana (FIGURA 37).

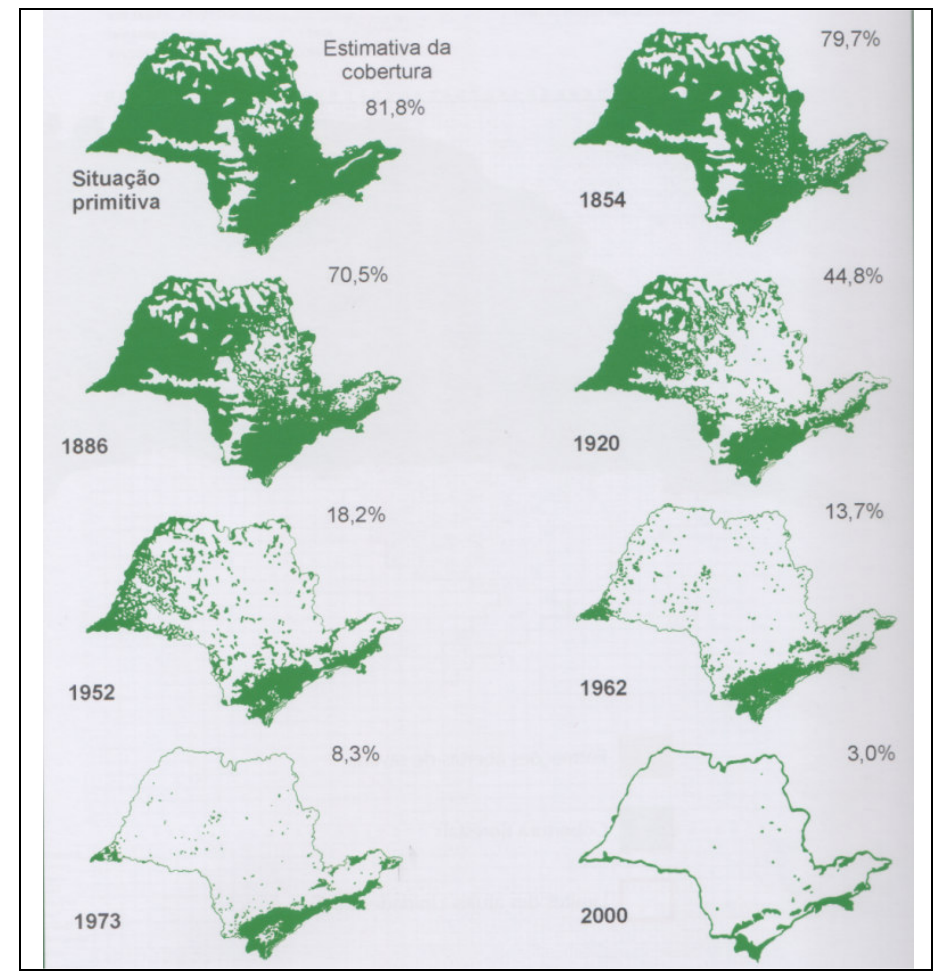

FIGURA 37 - Mapa de sequências do desmatamento no estado de São Paulo.

FONTE: VICTOR et al. (1979).

Atualmente, restam algumas florestas primitivas localizadas principalmente em encostas íngremes como a Serra do Mar e da Mantiqueira, que obviamente são de difícil acesso e também impróprias para o cultivo ou mesmo ocupação urbana.

Os remanescentes da vegetação primitiva paulista, a Mata Atlântica (Floresta Ombrófila Densa) é encontrada nestas serras ao longo da costa e também no rebordo do planalto. Essa vegetação é caracterizada por ser perene e bastante rica em epífitas e lianas, onde se encontra uma pluviosidade elevada. No interior do estado, de pluviosidade menor, encontra-se outro tipo de vegetação a mata semidecídua (Floresta Estacional Semidecidual) que contrasta com àquela desenvolvida em solos de arenitos e de terra roxa (AMBIENTE BRASIL, 2006).

Nas Serras de Mantiqueira e Bocaína existem ainda os pinheiros-do-paraná de floresta tropical, ou seja, presença de manchas de Floresta de Araucária (Floresta Ombrófila Mista). Existem ainda nas regiões interioranas de planalto entorno de 15\% do território 
paulista recoberto por Cerrado, onde na região sul encontra-se 1,3\% dessa vegetação característica dos campos gerais do Paraná.

\subsubsection{UNIDADES DE CONSERVAC̣ÃO}

No estado de São Paulo existem, além da capital, 644 municípios, onde encontramos a predominância de matas, trilhas, florestas, cachoeiras, cascatas, rios, estâncias climáticas e hidrominerais. O turismo ecológico conta com três estações e oito parques estaduais: Estação Ecológica Juréia-Itatins, Estação Ecológica de Bananal e a Estação Ecológica dos Chauás; Parque Estadual da Serra do Mar, Parque Estadual da Ilha do Cardoso, Parque Estadual de Ilha Bela, Parque Estadual de Pariquera Abaixo, Parque Estadual de Intervales, Parque Estadual do Vale do Ribeira, Parque Estadual de Iporanga e Parque Estadual de Apiaí.

O Litoral Paulista compreende em torno de $622 \mathrm{~km}^{2}$ de costa que são banhadas pelo Oceano Atlântico subdividido em litoral norte central e sul. Ao norte se encontram as praias de águas calmas, sendo algumas pouco habitadas com áreas de mata atlântica preservadas como Bertioga, Ubatuba, Caraguatatuba, São Sebastião e Ilha Bela.

E ao Sul situam-se santuários ecológicos e áreas de floresta tropical nativa (Estação Ecológica Juréia-Itatins) com a presença de cidades litorâneas de imensa beleza natural. Podemos citar as principais regiões de turismo como: Cananéia, Iguape, Ilha Comprida, Peruíbe. Na porção central encontra-se uma importante unidade litorânea, o Complexo Estuarino de Santos-São Vicente, hoje fortemente degradado, abrangendo os municípios de Santos, São Vicente, Praia Grande, Guarujá e Bertioga.

Existem também exuberantes cavernas no estado de São Paulo que tem atraído muitos turistas para a exploração e inclusão da prática de esportes radicais ligados ao meio ambiente. A proteção destes recursos ambientais é de extrema importância para a manutenção dos diversos ecossistemas existentes. Por isso, a legislação ambiental brasileira em nível municipal, estadual e federal apresenta disposições legais em termos de restrições de usos levando-se em conta as questões ambientais (MORAES, 1999).

A legislação ambiental não promove apenas a garantia de segurança de ambientes frágeis, tais como os manguezais, a restinga, a mata atlântica, mas também 0 desenvolvimento adequado de áreas urbanas. Por este motivo foram criadas as Unidades de Conservação (UC's) que regulamenta a preservação e conservação dos ambientes naturais. No estado de São Paulo as UC's são administradas pela SMA, e compreendem as Estações ecológicas, Estações experimentais, Parques estaduais, Florestas estaduais, Reservas estaduais, Viveiros florestais, Reservas biológicas, Parques ecológicos (INSTITUTO FLORESTAL, 2005) (FIGURA 38). 


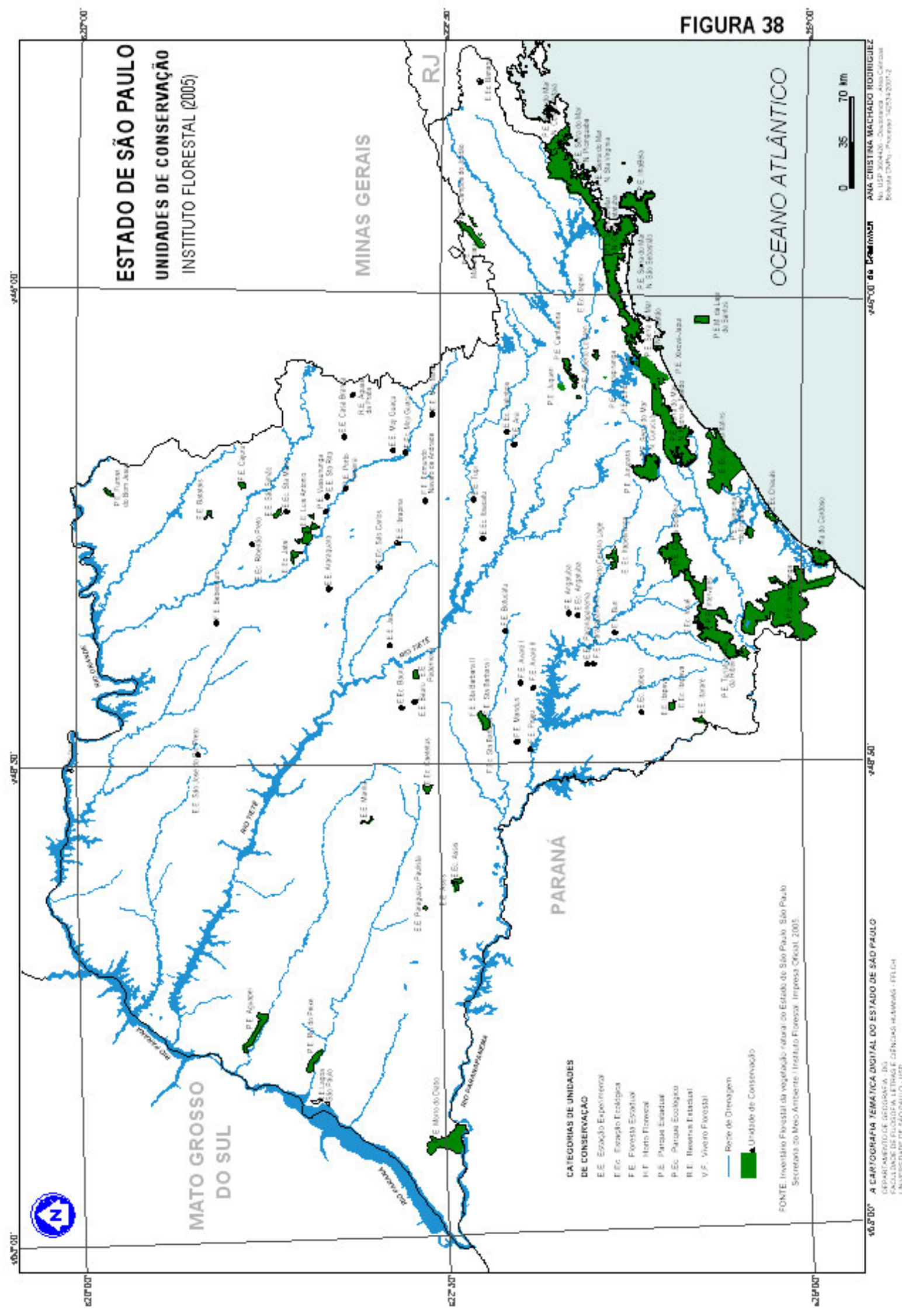


As UC’s de acordo com o Art. $2^{\circ}$ da Lei oㅜ 9.985 do SNUC (18/07/00), compreende o espaço territorial e seus recursos ambientais, incluído as águas jurisdicionais, com características naturais relevantes, legalmente instituídos pelo Poder Público, a qual tem como objetivo a conservação de limites definidos sob regime especial de administração aplicando garantias adequadas de proteção ambiental (SILVA, 2004).

No estado existem aproximadamente vinte (20) áreas de Preservação Ambiental (APA's), as quais foram instituídas pela Política Ambiental Federal e se constituem em unidades geográficas declaradas de interesse para a proteção ambiental, com a finalidade de assegurar o bem estar das populações humanas e conservar ou melhorar as condições ecológicas locais (art. $8^{\circ}$ da Lei Federal $n^{\circ}$ 6.902/81) (MORAES, 1999).

O Regulamento dos Parques Nacionais Brasileiros (RPNB) criado pelo Decreto № 84.017 de 21/09/79 considera os Parques como áreas geográficas extensas e delimitadas dotadas de atributos naturais e excepcionais como objeto de preservação permanente submetida à condição que não pode ser alienada e nem disposta no seu todo.

Atualmente, o Brasil com uma área territorial de $8.511 .996,3 \mathrm{~km}^{2}$ apresenta em torno de $8,13 \%$ de ocupação de áreas protegidas. Conforme dados do BRASIL (1984) a União gerencia um total de 184 UC's perfazendo cerca de 39.068.211 ha, o que correspondendo na verdade a $5 \%$ do território brasileiro.

O Regulamento dos Parques Nacionais Brasileiros (RPNB) criado pelo Decreto oㅡ 84.017 de 21/09/79 considera os Parques como áreas geográficas extensas e delimitadas dotadas de atributos naturais e excepcionais como objeto de preservação permanente submetida à condição que não pode ser alienada e nem disposta no seu todo.

Os Parques Nacionais correspondem a 360.325 ha, onde 45.000 ha pertencem ao Estado do Rio de Janeiro e 100.000 ha ao estado de São Paulo. Neste último, o maior Parque existente com aproximadamente $85.219,41$ ha é o Parque Estadual da Serra do Mar (PESM), e está sob a responsabilidade da Secretaria do Meio Ambiente (SMA).

Desta forma, por se tratar de um dos maiores parques faremos uma breve descrição sobre sua cobertura, leis, entre outros. Mas, os outros também têm significativa importância dentro do estado de São Paulo.

O PESM compreende toda a faixa litorânea abrangendo desde o Litoral Norte a partir da divisa com o Estado do Rio de Janeiro até o Litoral Sul com os municípios de Peruíbe e Pedro de Toledo (FIGURA 39). 


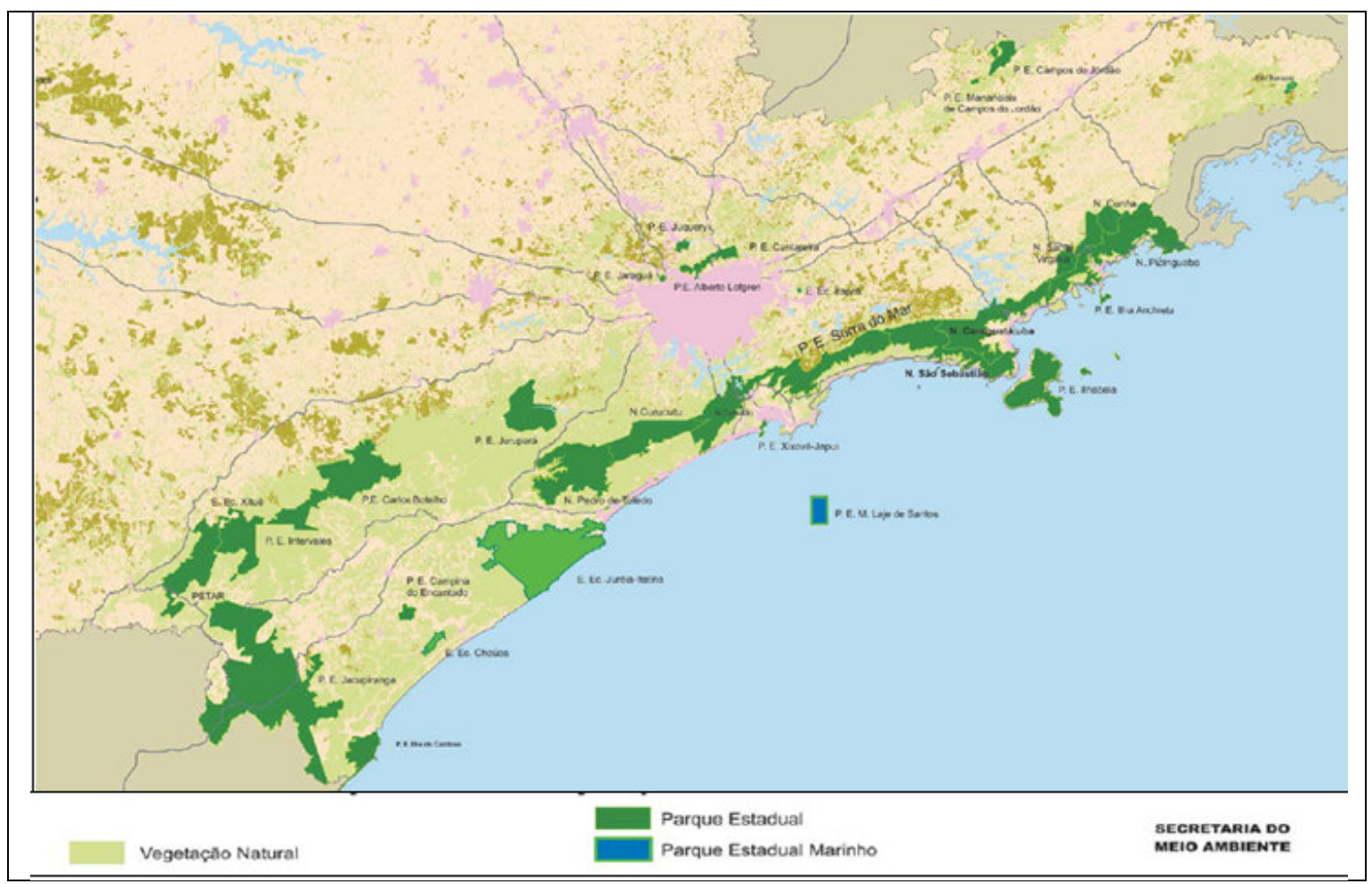

FIGURA 39 - Parque estadual da Serra do Mar (PESM).

FONTE: Secretaria do Meio Ambiente - SMA, SÃO PAULO (1998).

Este Parque que representa a maior porção contínua preservada de Mata Atlântica do Brasil abrange 28 municípios como: Ubatuba, Caraguatatuba, São Sebastião, São Vicente, Bertioga, Santos, Cubatão, Praia Grande, Mongaguá, Itanhaém, Peruíbe, Cunha, São Luiz do Paraitinga, Natividade da Serra, Paraibuna, Mogi das Cruzes, Suzano, Salesópolis, Biritiba Mirim, Santo André, São Bernardo do Campo, Ribeirão Pires, Rio Grande da Serra, São Paulo, Embu-Guaçú, Pedro de Toledo, Juquitiba e Barueri (SÃO PAULO, 1998).

O PESM é coberto pelas cabeceiras das bacias dos Rios Paraíba do Sul, Tietê e Ribeira de lguape em suas porções territoriais no Planalto Atlântico. E da área total do Parque apenas $30 \%$ das terras pertencem ao domínio do Estado, os restantes $70 \%$ estão sob ação discriminatória por iniciativa da Procuradoria Geral do Estado (PGE) e Instituto de Terras (ITESP).

O PESM é uma unidade de conservação com a maior área de florestas do domínio da Mata Atlântica associada a outros diversos ecossistemas, a qual contribui para a manutenção da diversidade biológica pelos bancos genéticos da flora e da fauna no estado de São Paulo. Ela é considerada como um ambiente de grande reposição da biodiversidade brasileira, porém vem sendo ameaçada pelo reflexo da ocupação e exploração desordenada de seus recursos naturais (MEIO AMBIENTE, 2004). 
A Mata Atlântica é uma floresta localizada em grandes altitudes sobre as serras litorâneas ao longo do Oceano Atlântico começando desde o Rio Grande do Sul e até o Nordeste. Esta mata é encontrada nas Serras do Mar e da Mantiqueira localizada nos Estados de São Paulo, Minas Gerais, Rio de Janeiro e Espírito Santo, onde em seu arredor se encontra segundo RIZZINI (1979) numerosas dependências mediterrâneas com formas de capões e matas de galeria.

Segundo a SOS Mata Atlântica (2003) pelo estudo do "Atlas da Evolução dos Remanescentes Florestais e Ecossistemas Associados", a área ocupada por domínio da Mata Atlântica com seus ecossistemas era de 8.682.412 ha em 1990 e de 8.182.095 ha em 1995, correspondendo a uma redução de 500.317 ha dos remanescentes, o que mostra uma taxa de desmatamento em torno de $5,76 \%$ ao ano.

O Decreto de no 750 de 10/02/93, além das Leis da Constituição Federal e Estadual menciona a disposição sobre o corte, a exploração e a supressão da vegetação primária ou nos estágios avançados e médios de regeneração da Mata Atlântica, e dão outras providências. Pois, a Mata Atlântica mesmo em seus estágios de recuperação e regeneração deve ser arduamente preservada permanentemente devido ao seu grande caráter de natureza ecológica e paisagística.

Entretanto, no Decreto de no 750 de 10/02/93 a Mata Atlântica é considerada como Patrimônio Nacional se evidenciando uma lei de sentido formal e material que pode possibilitar a utilização das florestas deste ecossistema. Desta forma, é necessário que o Congresso Nacional aprove leis para disciplinar o uso e a exploração racional e sustentável das florestas transformadas em Patrimônio Nacional, como é o caso da Mata Atlântica.

Neste sentido, a Câmara dos Deputados aprovou e encaminhou ao Senado Federal em 9/12/03 o Projeto de Lei no 3.285, dispondo sobre a utilização e proteção do bioma Mata Atlântica. Este projeto acolhe muitos princípios, conceitos e definições do Decreto de ํㅜ 750 de 10/02/93 e confere maior dimensão ao conceito do bioma Mata Atlântica (SILVA, 2004).

Entretanto, não basta existirem leis, decretos e resoluções elaboradas pelos governantes para a preservação das florestas, se precisa de investimento financeiro e empenho do governo federal, estadual e municipal, e também conscientização da população no sentido de frear a degradação do bioma Mata Atlântica. Pois, o levantamento feito pela organização da SOS Mata Atlântica indica que somente $8,8 \%$ da área original ainda remanescem revestidos com floresta preservada (ISA, 1995).

E Segundo GERAQUE (2006) publicado na Revista de Pesquisa FAPESP, a Mata Atlântica voltou a crescer através da regeneração da vegetação natural ao longo de dez anos, estes dados são do Instituto Florestal de São Paulo. Esse aumento representa Rodríguez, A. C. M. 
aproximadamente $2,86 \%$, o que corresponde a uma área de $808 \mathrm{~km}^{2}$ localizados no Vale do Paraíba e no litoral.

\subsection{CARACTERISTICAS SÓCIOECONÔMICAS}

\subsubsection{PROCESSO DE OCUPAÇÃO}

O conhecimento da colonização e fundação do estado de São Paulo ou de qualquer outro território é de fundamental importância para o entendimento da organização atual da estrutura social, econômica, política e ambiental brasileira.

A formação histórica do estado de São Paulo se iniciou durante a colonização em 1532 com a fundação da Vila de São Vicente (a mais antiga do Brasil) por Martin Afonso de Souza (AMBIENTE BRASIL, 2006). Em 1554, um grupo de jesuítas inaugurou o Colégio de São Paulo como núcleo da atual cidade de São Paulo. E no século XVII, devido ao grande isolamento da região os paulistas se aventuram pelo interior armados com bandeiras em busca de mão-de-obra indígena e ouro.

A economia naquela época era baseada exclusivamente na agropecuária de subsistência, isso até por volta do século XIX quando se deu o início da plantação de café. Essa cultura possibilitou aos paulistas um grande avanço no desenvolvimento da região com a vinda de um grande número de imigrantes provindos de várias regiões do Brasil e, mesmo do interior.

A imigração de outros estados do Brasil trouxe a presença de diversas etnias e classes sociais em São Paulo. Pois, devido à busca de melhoria de vida e a procura de emprego entre outros fatores favoreceram a imigração não somente de brasileiros como também de estrangeiros. O capital acumulado e o fornecimento de matéria-prima nesta nova fase possibilitam uma ótima capacitação dos imigrantes europeus gerando um crescimento industrial. E se intensificam também as condições de obtenção de energia elétrica.

Historicamente, a expansão da cultura cafeeira ocasionou a fundação de muitas vilas e cidades no estado de São Paulo. Com o emprego de técnicas rudimentares e o cultivo do café esgotavam-se os solos, logo os agricultores foram obrigados a avançar para o uso de novas terras. Deste modo, as lavouras desta cultura deixaram o Vale do Paraíba e expandiram-se, primeiro para o centro e centro-norte e depois para o oeste paulista, impulsionando a economia do Estado e incentivando a construção de ferrovias para o transporte do produto. A expansão da malha ferroviária e, posteriormente, a rodoviária, foi responsável pelo crescimento de muitas cidades no estado de São Paulo (FIGURA 40). 


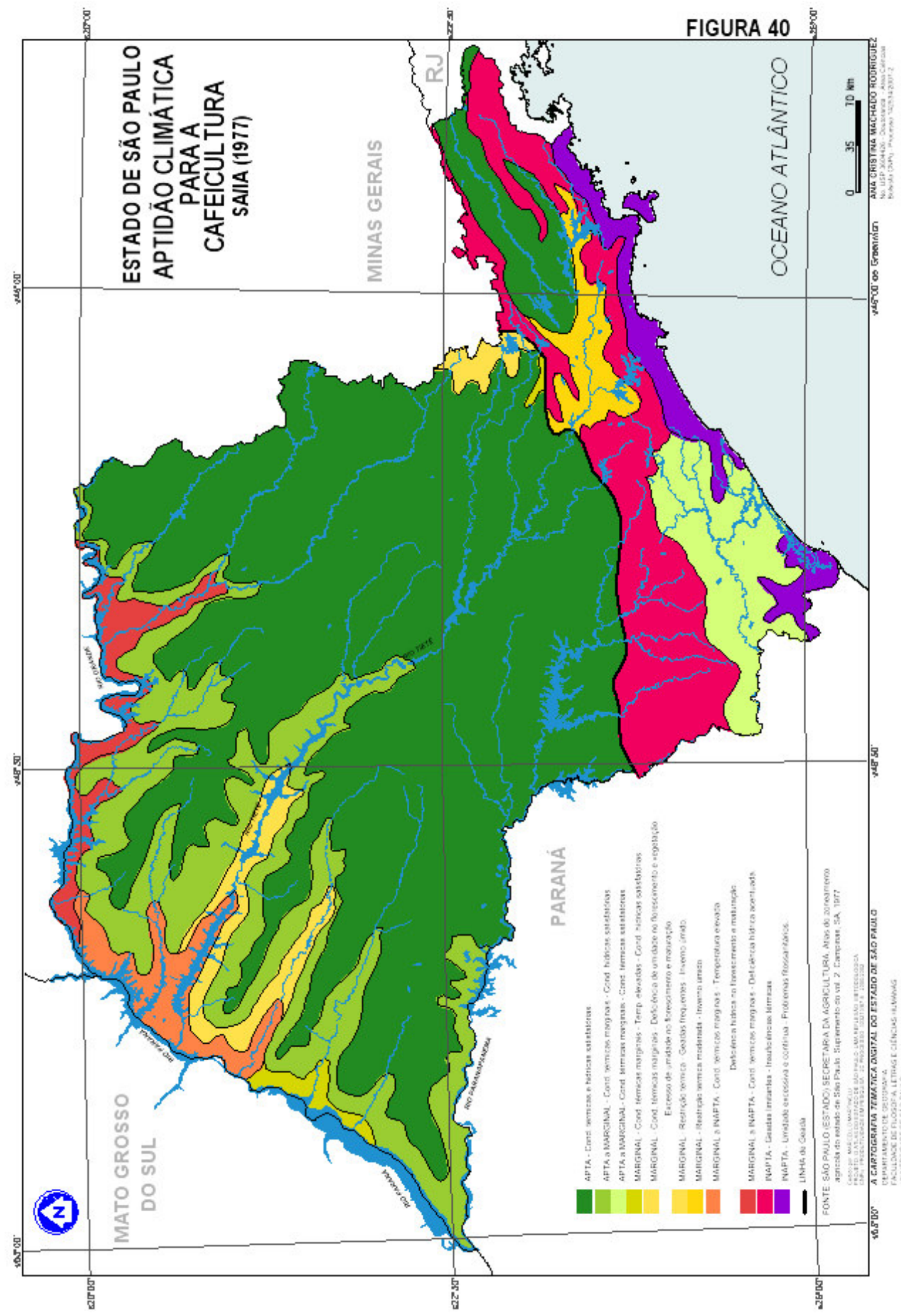


A proximidade da cidade de São Paulo, a capital, (principal centro consumidor) ao porto de Santos possibilitou o desenvolvimento econômico da região.

Portanto, o processo de urbanização originado em São Paulo pelo complexo cafeeiro adquiriu características particulares: uma rede urbana amplamente ramificada, articulada e hierarquizada, tendo no seu topo o comando da capital de São Paulo (estrategicamente situada no planalto entre o interior cafeeiro e o porto de Santos) e, nas suas pontas, pela extensão do seu sistema viário para além das fronteiras do estado, a comunicação com os estados vizinhos e seus mercados, possibilitando que se estendesse a área de influência paulista para muito além de seus limites político - administrativos.

Os capitais provenientes do café concentravam-se primeiramente na capital federal, a cidade do Rio de Janeiro, mas, com o crescimento da cultura cafeeira no interior de São Paulo e a exportação do produto pelo porto de Santos, passaram a se concentrar, principalmente, na capital paulista, o núcleo gerenciador do suporte da rede urbana recémformada.

A união de São Paulo com Minas Gerais no domínio da máquina eleitoral brasileira faz surgir uma política chamada "Café-com-leite". E durante a Revolução de 1930 a queda da liderança da oligarquia cafeeira promove a Revolução Constitucionalista de 1932, a qual é derrotada.

Mas, logo após a Segunda Guerra Mundial (1939-1945), o mercado consumidor nacional adquiriu dimensões consideráveis e atraentes para as multinacionais. A Região Metropolitana de São Paulo foi escolhida como o local de implantação de $80 \%$ dos investimentos estrangeiros, por reunir as melhores condições estruturais para a acumulação de capital, como: infra-estrutura urbana, energética e de transporte já desenvolvidas; concentrações demográficas quantitativamente densas para constituir mão-de-obra abundante e qualitativamente expressiva para funcionar como força de trabalho especializado; mercado consumidor com poder aquisitivo considerável, além de já concentrar as principais indústrias de base para as multinacionais.

Assim, o crescimento concentrado na Região Metropolitana de São Paulo ocorreu, principalmente, nos municípios localizados no entorno ao da capital paulista, notadamente no ABCD (Santo André, São Bernardo do Campo, São Caetano do Sul e Diadema). E no final dos anos 1950, mais de $40 \%$ de toda a produção industrial brasileira e quase $3 / 4$ da produção de bens de capital e consumo duráveis estava concentrada na Região Metropolitana de São Paulo (FIGURA 41). 


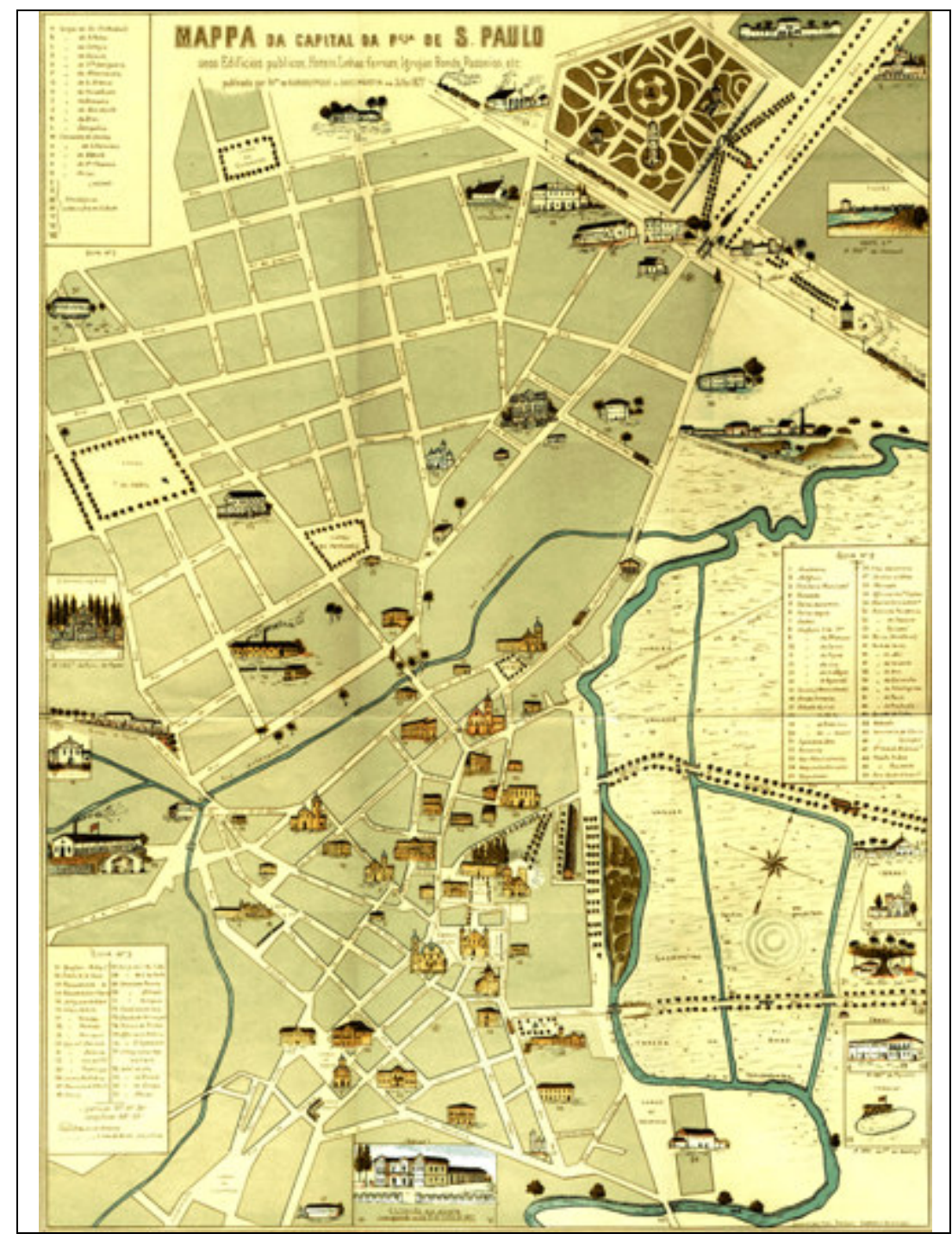

FIGURA 41 - Planta da cidade de São Paulo - SP.

FONTE: Comissão do IV Centenário da Cidade de São Paulo - SP (1954).

No entanto a partir da década de 1970, e intensificando-se nos anos 1980, inicia-se no estado de São Paulo uma dispersão das atividades industriais do aglomerado metropolitano, com as indústrias estruturando-se em direção dos traçados das principais vias de transporte rodoviário que partem da capital paulista rumo ao interior do estado.

E a principal causa de tudo isso era devido aos custos de aglomeração, como o alto preço do solo urbano, congestionamento da metrópole, aliados aos problemas de ordem ambiental e à deterioração das condições de vida provocados pela concentração industrial. Fase denominada de "interiorização da indústria paulista", utilizada por muitos autores para caracterizar a expansão industrial dos anos 1970 para o interior do estado.

Mas, a indústria paulista desde sua gênese, esteve presente no interior, haja vista que no final da década de 1920, cerca de $30 \%$ da produção industrial paulista era 
proveniente do interior, sobretudo das regiões de Sorocaba e de Campinas, que concentravam $21,2 \%$ dos operários do estado de São Paulo.

Segundo a SEADE (1988), os principais fatores que influenciaram decisivamente o crescimento industrial do interior paulista nas décadas de 1970 foram:

1) a modernização da agricultura com possibilidades de desenvolvimento de estruturação agroindustrial;

2) os investimentos estatais federais advindo da instalação de refinarias de petróleo em Paulínia e São José dos Campos, a consolidação do pólo petroquímico de Cubatão e a expansão da Companhia Siderúrgica Paulista (COSIPA), a instalação de plantas industriais no setor de eletrônica, informática e telecomunicações em Campinas, além do pró-álcool, projetos que estimularam a instalação de novas indústrias complementares;

3) a política estadual de construção de uma malha viária ampla e moderna, que diminuíram os custos de transportes e propiciaram novas vantagens para a localização industrial;

4) a elevação dos custos de aglomeração na Região Metropolitana de São Paulo.

Os anos de 1970 a 1980 correspondem a um período de desconcentração e não de descentralização, pois o que se transfere são apenas as unidades produtivas da metrópole para outras áreas, principalmente as mais próximas da capital e bem servidas por modernos meios de transporte.

No entanto, o comando decisório e a gestão das empresas continuam concentrados na metrópole paulista, bem como as linhas de maior conteúdo tecnológico, ou que, por diversas razões, demandassem uma mão-de-obra de maior qualificação. Já a descentralização industrial demanda não apenas a transferência de unidades produtivas, como também o processo decisório e o comando das empresas, o que não vem ocorrendo de modo geral.

Desta forma, adquiriu maior nitidez, nos anos 1980, a expansão da atividade industrial pelo entorno metropolitano seguindo os principais eixos rodoviários até uma distância de, aproximadamente, $250 \mathrm{~km}$ da capital, não se criando um novo centro industrial que fizesse com que a metrópole perdesse a sua posição de hierarquia. Mas, sem dúvida, um fenômeno novo estava em pleno vapor: um interior moderno e urbanizado passava a acolher a desconcentração relativa da indústria paulistana.

A região metropolitana de São Paulo não deixou de ser a principal área industrial do país, mas vem crescendo a ritmos mais lentos do que algumas regiões do interior do Estado e vai se especializando nas atividades do setor terciário e quaternário. 
Os serviços de alta tecnologia se concentram na metrópole, como é de praxe nas grandes metrópoles contemporâneas em todo o mundo. A diminuição no ritmo de crescimento metropolitano foi relativamente compensada pelo crescimento urbano-industrial de cidades e aglomerações urbanas que se encontram no interior do estado. Além do aumento industrial, o interior também teve suas atividades terciárias desenvolvidas, principalmente nas sedes regionais de Campinas, São José dos Campos, Sorocaba, Ribeirão Preto e Santos.

Assim, a expansão urbano-industrial da metrópole paulistana, se diversifica em direção à região de Campinas, à Baixada Santista, ao Vale do Paraíba e à região de Sorocaba, polarizando diversos centros urbanos importantes, seguindo os principais eixos rodoviários do estado de São Paulo, respectivamente: rodovias Anhangüera e Bandeirantes (SP 330 e SP 348); Anchieta e Imigrantes (SP 150 e SP 160); Presidente Dutra (BR 116) e a rodovia Castelo Branco (SP 280).

As vias de transporte de trânsito rápido associadas à infra-estrutura logística de comunicação por internet e fibras óticas, que proporcionam condições mais favoráveis para a localização industrial e a dinâmica interna das cidades em sua organização em forma de redes, constituem os eixos de desenvolvimento. Esses eixos estão associados a uma cadeia de núcleos urbanos, de diferentes tamanhos, situados ao longo de uma via de transporte de alta capacidade que estimula a localização da atividade industrial e facilita 0 estabelecimento de relações funcionais internas.

As vias de transporte de grande capacidade que constituem os eixos de desenvolvimento são autopistas (rodovias duplicadas), ferrovias modernas (eletrificadas) e infovias (cabos de fibra óptica, telefonia, rede mundial de computadores etc.).

A infra-estrutura de transporte adequada e de qualidade propicia condições mais favoráveis para a dinâmica econômica dos centros urbanos situados nas proximidades dos eixos, principalmente no tocante à localização das mais diversas atividades industriais, com as empresas buscando reduções do tempo necessário aos deslocamentos de matériasprimas e mercadorias, bem como o aumento da competitividade produtiva.

Enfim, no estado de São Paulo existem eixos ou regiões dentro de regiões de governo e administrativas com perfis socioeconômicos muito diferenciados, e as disparidades econômicas e sociais são muito claras: enquanto algumas áreas próximas à capital e bem servidas por determinados eixos rodoviários atraem os mais diversos investimentos públicos e privados, como as Regiões Administrativas de Campinas, Sorocaba, Vale do Paraíba, Ribeirão Preto e Região Central (São Carlos e Araraquara), outras regiões mais afastadas do entorno metropolitano, com vias de transporte mais 
precárias e que não apresentam vantagens de locomoção para o capital, como o Vale do Ribeira, Litoral Sul e o Pontal do Paranapanema, permanecem como áreas estagnadas economicamente ou com um crescimento muito inferior às áreas de maior dinamismo.

Além, da produção de produtos agrícolas e industriais, o estado de São Paulo é conhecido nacionalmente e internacionalmente por seu potencial de trabalho, negócios e desenvolvimento econômico. Onde, são valorizados ainda os seus lados culturais e também turísticos pela grande característica de beleza cênica e bucólica.

A Capital de São Paulo tem uma intensa vida cultural e artística, além do turismo que chega a realizar mais de 45 mil eventos por ano. Os principais pontos turísticos de São Paulo são parques, monumentos históricos, shoppings e também alguns bairros residenciais que ainda mantém suas tradições.

\subsubsection{USO E COBERTURA DA TERRA}

Este uso do território paulista é consoante com as inúmeras características naturais peculiares e particulares tornando o meio mais ou menos adequado à realização de determinada atividade. Estamos falando de suas próprias aptidões físicas que com sua degradação podem gerar áreas de maior fragilidade ambiental trazendo riscos ao meio ambiente.

O cultivo desacelerado da cana-de-açúcar é uma delas. A produção desta cultura só ganhou impulso na década de 70 por conta do automóvel bi-combustível, além da gasolina, o etanol. No estado de São Paulo nos anos 2003-2004 foram contabilizados cerca de 207.572.538 toneladas correspondendo a $61,35 \%$ da produção nacional e a $69,52 \%$ da produção na Região Centro-Sul (UNICA, 2005). E segundo o IBGE (2010) em 2006 essa produção nacional passou para 231.977.247 toneladas sinalando um maior crescimento na produção de bi-combustível.

O estado de São Paulo é caracterizado por diferentes usos e coberturas da terra, alguns hoje como o Município de São Sebastião foram transformados em solos desnudos e ocupados sem nenhuma infra-estrutura apropriada para controlar eventuais acidentes como desmoronamentos ou mesmo deslizamentos em épocas de chuvas torrenciais.

Segundo os estudos de SKOLONSKI et al. (1999) e EVA et al. (2002) os usos e coberturas da terra mais atuais existentes no Brasil são indicados pelas seguintes classes: Cobertura vegetal, extrativismo vegetal, agricultura, pecuária, agropecuária, mineração, área urbana e áreas especiais.

Enquanto que no estado de São Paulo dados segundo CHIARINI et al. (1978) afirmam que o primeiro levantamento do uso e cobertura da terra foi realizado em 1962 por 
aerofotografia na escala de 1:25.000. E a mesma era destinada para estudos no setor de agricultura. Os resultados foram apresentados em carta na escala de 1:1.500.00 segundo as convenções adotadas das folhas topográficas do Instituto Geográfico e Geológico - IGG (FIGURA 42).

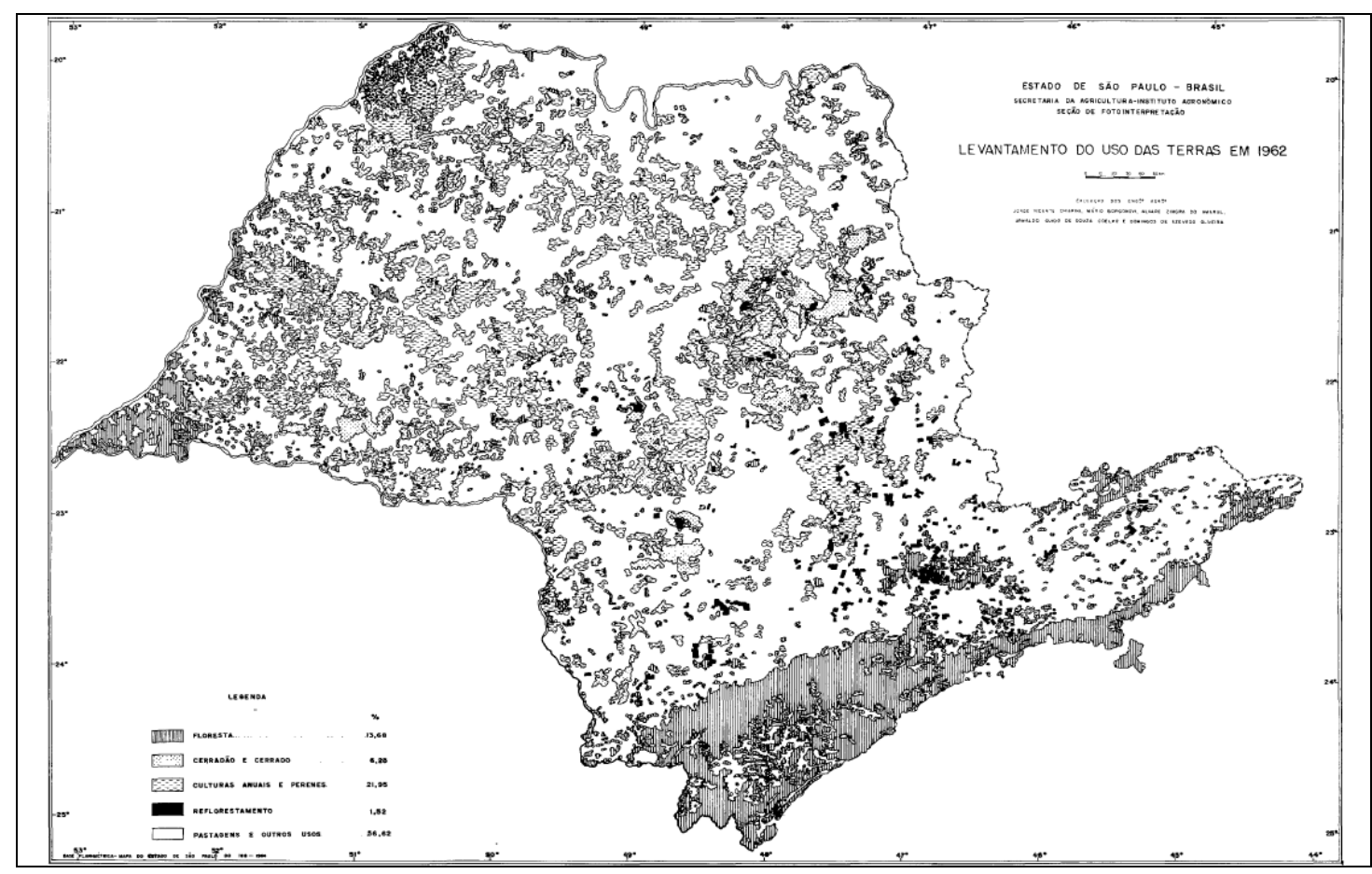

FIGURA 42 - Mapa do levantamento do uso das terras em 1962 do estado de São Paulo.

FONTE: CHIARINI et al. (1978).

$\mathrm{Na}$ TABELA 14 relacionamos as principais categorias de uso e cobertura da terra identificada neste levantamento, assim como a caracterização das mesmas no estado.

TABELA 14 - Tipos de usos da terra com sua caracterização no estado de São Paulo.

\begin{tabular}{c|l|l}
\hline No. & TIPO DE USO DA TERRA & \multicolumn{1}{c}{ CARACTERIZAÇÃO } \\
\hline 1. & FLORESTA & $\begin{array}{l}\text { Cobertura vegetal típica formada por florestas com declives } \\
\text { bastante pronunciados e de difícil acesso. }\end{array}$ \\
\hline 2. & REFLORESTAMENTO & Área reflorestada. \\
\hline 3. & CERRADÃO & $\begin{array}{l}\text { Razoável série de espécies vegetais com porte em torno de 10,0 } \\
\text { metros de altura composta por um andar de árvores esparsas que } \\
\text { alcançam 15m e no andar intermediário as árvores são mais densas } \\
\text { entorno de 3 a 12 metros se assemelhando muito com as florestas. }\end{array}$ \\
\hline 5. & CERRADO & $\begin{array}{l}\text { Constitui-se por árvores de porte médio e arbustos. Incluem-se } \\
\text { variações entre cerradão e campo, tais como cerradinho, campo } \\
\text { cerrado, campo sujo, etc. }\end{array}$ \\
\hline 5. & CAMPO & $\begin{array}{l}\text { Tipo de cobertura vegetal muito típica formada essencialmente por } \\
\text { gramíneas naturais. }\end{array}$ \\
\hline 6. & BANHADO & $\begin{array}{l}\text { Formado pelas várzeas que podem ou não apresentar-se } \\
\text { encharcadas. }\end{array}$ \\
\hline 7. & PASTAGEM & $\begin{array}{l}\text { A cobertura vegetal dominante é gramínea de forma similar com os } \\
\text { campos. }\end{array}$ \\
\hline \hline
\end{tabular}




\begin{tabular}{c|l|l}
\hline \hline 8. & CULTURA & Abrangem as culturas anuais, as semiperenes e as perenes. \\
\hline 9. & TERRAS NÃO AGRÍCOLAS & Abrangem as áreas urbanas, estradas, rios, lagos e represas. \\
\hline 10. & COBERTURA RESIDUAL & Compreendem as que não se enquadraram nas já descritas acima. \\
\hline \hline
\end{tabular}

FONTE: Adaptado de CHIARINI et al. (1978).

E segundo TROPPMAIR (1983) as principais classes existentes no estado de São Paulo são: Mata, Mangue, Cerrado, Hortifruticultura, Higrocultura, Pastagem, Mata secundária, Culturas temporárias, Área urbana, Café, Cana-de-açúcar, Laranja, Reflorestamento e Campos (FIGURA 43).

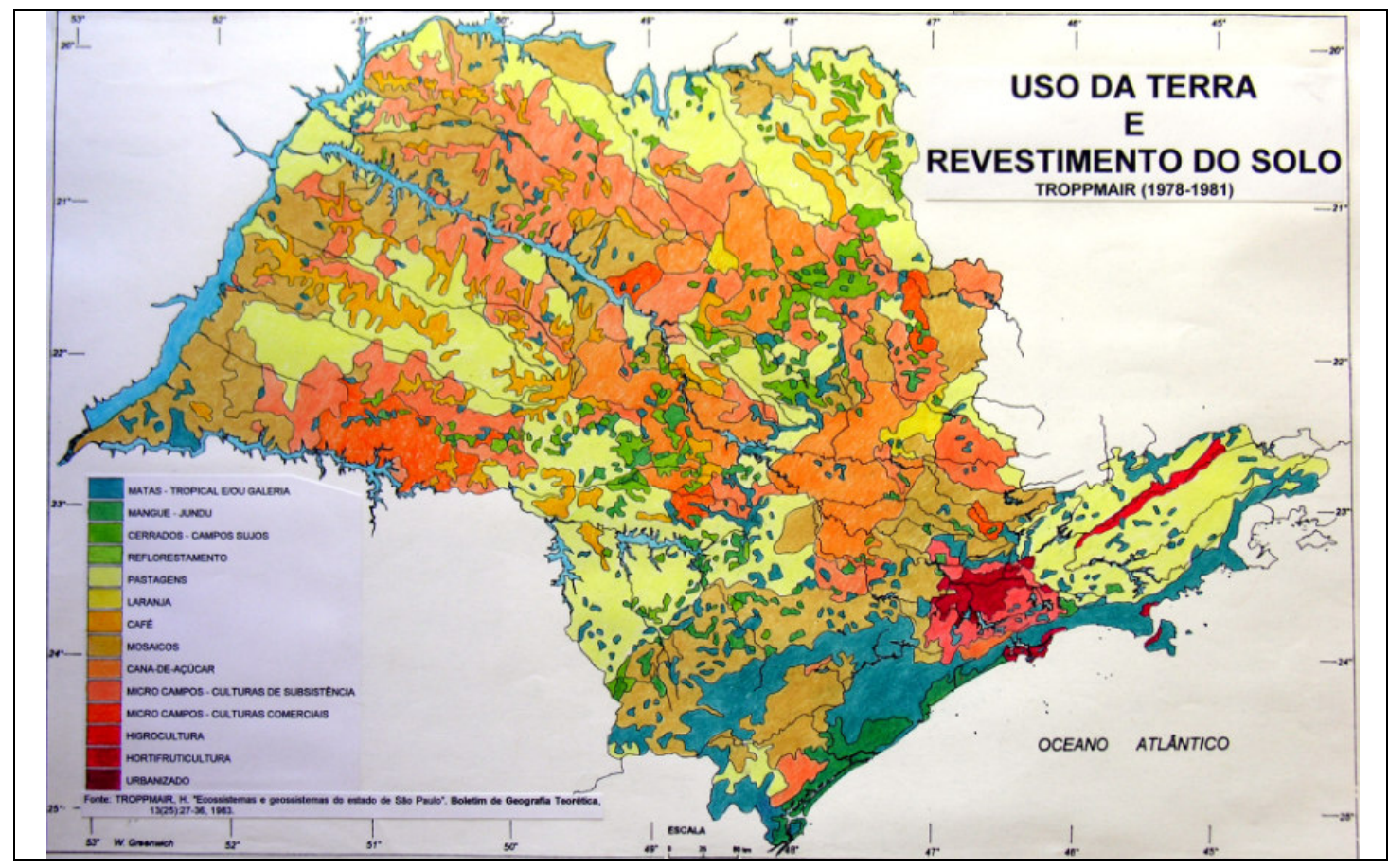

FIGURA 43 - Mapa de uso e cobertura da terra do estado de São Paulo.

FONTE: TROPPMAIR (1983).

\subsubsection{POPULAÇÃO}

A população vem crescendo a taxas cada vez mais espantosas, com pessoas vindo a procurar melhores condições de vida e de infra-estrutura para sua sobrevivência. Com isso o intenso processo de ocupação do território devida à distribuição espacial desse grande contingente populacional trouxe a utilização maciça dos recursos naturais.

Desta forma, a ocupação desordenada e desenfreada das variadas formas de uso e cobertura da terra afeta os processos naturais causando efeitos indesejáveis no equilíbrio ambiental como: desmatamentos, queimadas, manejo inadequado do uso intensivo dos solos, lançamento de efluentes nos mananciais, uso indiscriminado de agrotóxicos entre outros (COSTA, 2005). 
No estado de São Paulo esse alto crescimento populacional advém da imigração a partir de diversas regiões do Brasil, cuja população vem em busca de melhores condições de vida, emprego, saúde, etc. O que sobrecarrega os setores de saúde e favorece a ocupação de encostas gerando um grande número de favelas clandestinas, e em curto prazo uma alta taxa de criminalidade.

Segundo o IBGE (2000) os dados apresentavam que a população paulista era de aproximadamente 36.966 .527 habitantes comprovando o que muitos afirmavam sobre o forte "inchamento" do estado dividido em 645 municípios. Dos quais muitos se apresentavam com um desenvolvimento fora do comum e outros em fase de desenvolvimento relacionados tanto à população como a economia (FIGURA 44).

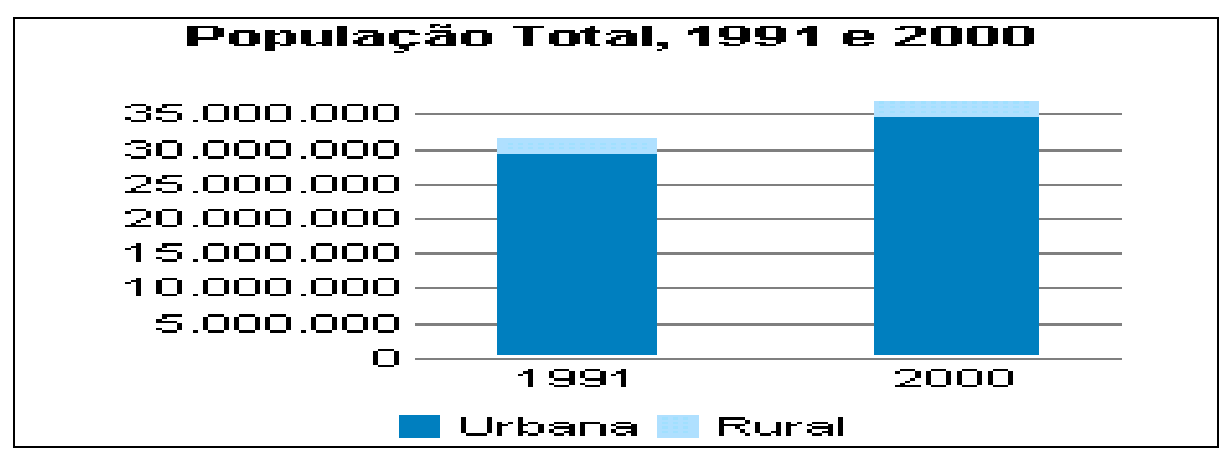

FIGURA 44 - Crescimento populacional do estado de São Paulo (1991-2000).

FONTE: IBGE (2005).

$\mathrm{Na}$ atualidade, despontam, no estado de São Paulo, três grandes aglomerados populacionais, correspondendo às regiões metropolitanas de São Paulo, Baixada Santista e Campinas, as quais representam o equivalente a $58,70 \%$ da população total do estado, que é de 36.966.527 habitantes para o censo de 2000 (IBGE, 2000).

A Região Metropolitana (R. M.) de São Paulo é formada por 39 municípios que, juntos, ocupam uma superfície de 8.051 km2 e apresenta uma população de 17,8 milhões de habitantes. O que a coloca como o terceiro maior aglomerado do mundo, deixando para trás Tóquio (Japão) e a Cidade do México (EMPLASA, 2000) (TABELA 15).

TABELA 15 - Relação da população dos municípios da R. M. de São Paulo.

\begin{tabular}{l|r|l|r|l|r}
\hline \hline \multicolumn{1}{c|}{ MUNICÍPIOS } & \multicolumn{1}{c|}{ HAB. } & MUNICÍPIOS & \multicolumn{1}{c|}{ HAB. } & \multicolumn{1}{c}{ MUNICÍPIOS } & HAB. \\
\hline Arujá & 59.080 & Guararema & 21.880 & Ribeirão Pires & 104.336 \\
\hline Barueri & 208.028 & Guarulhos & 1.071 .299 & Rio Grande da Serra & 36.352 \\
\hline Biritiba-Mirim & 24.567 & Itapecerica da Serra & 129.156 & Salesópolis & 14.330 \\
\hline Caieiras & 70.849 & Itapevi & 162.421 & Santa Isabel & 43.473 \\
\hline Cajamar & 50.244 & Itaquaquecetuba & 272.416 & Santana de Parnaíba & 74.722 \\
\hline Carapicuíba & 343.668 & Jandira & 91.721 & Santo André & 648.443 \\
\hline Cotia & 148.082 & Juquitiba & 26.479 & São Bernardo do Campo & 700.405 \\
\hline \hline
\end{tabular}




\begin{tabular}{l|r|l|r|l|r}
\hline \hline Diadema & 356.389 & Mairiporã & 59.708 & São Caetano do Sul & 140.144 \\
\hline Embu & 206.781 & Mauá & 363.112 & São Lourenço da Serra & 12.185 \\
\hline Embu-Guaçu & 56.709 & Moji das Cruzes & 329.680 & São Paulo & 10.406 .166 \\
\hline Ferraz de Vasconcelos & 141.939 & Osasco & 650.993 & Suzano & 228.439 \\
\hline Francisco Morato & 133.248 & Pirapora do Bom Jesus & 12.338 & Taboão da Serra & 197.460 \\
\hline Franco da Rocha & 107.997 & Poá & 95.724 & Vargem Grande Paulista & 32.548 \\
\hline
\end{tabular}

TOTAL GERAL

17.878.703

FONTE: SEADE/IBGE/EMPLASA (2000).

A Região Metropolitana de São Paulo é detentora do maior controle de capital privado do Brasil sediando um dos mais importantes complexos industriais, comerciais e principalmente financeiros que dirigem as atividades econômicas privadas no país.

A população que se concentra na Região metropolitana de São Paulo é de grande volume de famílias de baixa renda que apresenta uma situação de déficit habitacional e falta de infra-estrutura, o que leva a citada metrópole paulista com construções desordenadas originando favelas e cortiços.

Já a Região metropolitana da Baixada Santista é composta de nove municípios e possui uma área de $2.372 \mathrm{~km}^{2}$ com uma população de 1,4 milhões de moradores (EMPLASA, 2000)(TABELA 16).

TABELA 16 - Relação da população dos municípios da R. M. da Baixada Santista - SP.

\begin{tabular}{l|r|l|r|l|l}
\hline \hline MUNICÍPIOS & \multicolumn{1}{|c|}{ HAB. } & MUNICÍPIOS & HAB. & MUNICÍPIOS & HAB. \\
\hline Bertioga & 30.903 & Itanhaém & 71.947 & Praia Grande & 191.811 \\
\hline Cubatão & 107.904 & Mongaguá & 35.106 & Santos & 417.777 \\
\hline Guarujá & 265.155 & Peruíbe & 51.384 & São Vicente & 302.678 \\
\hline TOTAL GERAL & \multicolumn{4}{|c}{1.474 .665} \\
\end{tabular}

FONTE: SEADE/IBGE/EMPLASA (2000).

Essa região metropolitana possui um Parque industrial que é composto por empresas complementares ás da Grande São Paulo. As mesmas têm siderúrgicas, petroquímicas e atividades portuárias. Podemos destacar o Parque industrial de Cubatão e o complexo portuário de Santos considerado um dos maiores da América do Sul que responde por mais de um terço de todo o comércio exterior do Brasil.

Na R. M. da Baixada Santista também se manifesta o comércio de exportação por contar com o Porto de Santos, além das atividades turísticas pela existência de inúmeras praias que em períodos de férias e feriados prolongados acolhem cerca de milhões de banhistas. 
O turismo vem se intensificando nos últimos anos devido ao patrimônio histórico da região tendo em vista a cidade de São Vicente, a qual foi a primeira vila fundada no país por Martim Afonso de Souza em 1532.

Já a R. M. de Campinas, a mais recente do estado é composta por 19 municípios ocupando uma área de $3.348 \mathrm{~km} 2$ e uma população de 2,3 milhões de habitantes (EMPLASA, 2000)(TABELA 17).

TABELA 17 - Relação da população dos municípios da R. M. de Campinas - SP.

\begin{tabular}{l|r|l|r|l|c}
\hline \hline MUNICÍPIOS & \multicolumn{1}{|c|}{ HAB. } & MUNICÍPIOS & HAB. & MUNICÍPIOS & HAB. \\
\hline Americana & 182.084 & Indaiatuba & 146.829 & Pedreira & 35.242 \\
\hline Artur Nogueira & 33.089 & Itatiba & 80.844 & Santa Bárbara d'Oeste & 169.735 \\
\hline Campinas & 967.921 & Jaguariúna & 29.450 & Santo Antônio da Posse & 18.145 \\
\hline Cosmópolis & 44.367 & Monte Mor & 37.111 & Sumaré & 196.055 \\
\hline $\begin{array}{l}\text { Engenheiro } \\
\text { Coelho }\end{array}$ & 10.025 & Nova Odessa & 42.066 & Valinhos & 82.773 \\
\hline Holambra & 7.231 & Paulínia & 51.242 & Vinhedo & 47.104 \\
\hline Hortolândia & 151.669 & & & & \\
\hline TOTAL GERAL & & \multicolumn{5}{|l}{} \\
\hline
\end{tabular}

FONTE: SEADE/IBGE/EMPLASA (2000).

O desenvolvimento da R. M. de Campinas é marcado pela expansão da cultura do café, logo nas primeiras décadas do século XX. Essa região metropolitana vem atualmente ocupando uma importante posição econômica no cenário estadual e nacional por ter um parque industrial diversificado especializado em trabalhos tradicionais de indústrias alimentícias e têxteis, assim como no material de transporte, incluindo a automobilística, a química e mecânicas.

É destacada também por suas atividades de alta tecnologia no campo de informática, microeletrônica e das telecomunicações. É considerada como um grande pólo tecnológico por sediar importantes centros de pesquisas como a Universidade de Campinas (UNICAMP), o Instituto Agronômico de Campinas (IAC), o Centro Tecnológico para Informática (CTI) e o Laboratório Nacional de Luz Síncroton (LNLS).

A sede regional, Campinas ainda possui atividade de ponta como uma estrutura agrícola e agroindustrial bastante significativa e desempenha atividades terciárias de expressiva especialização. 
Desta forma, as três regiões metropolitanas (São Paulo, Baixada Santista e Campinas) lideradas pela primeira são interdependentes economicamente e formam uma rede metropolitana integrada com funções produtivas complementares.

Mas, com a expansão urbano-industrial destas metrópoles é evidente que outras áreas em suas proximidades sejam criadas dinamizando e integrando economicamente ao já existente aglomerado metropolitano. Estamos falando das concentrações urbanas do Vale do Paraíba, de Sorocaba, de Jundiaí e de outras do entorno metropolitano que vêm sendo chamadas de "Complexo Metropolitano Expandido" (EMPLASA, 2000).

\subsubsection{EDUCAÇÃO}

O investimento do governo na educação visa umas das principais prioridades para a formação de uma sociedade. Para isso é necessário criar infra-estruturas que possam atender tanto ao discente como ao docente.

A superlotação nas salas de aula, a desvalorização profissional, os baixos salários e a falta de propostas pedagógicas de qualidade tem prejudicado bastante o sistema de ensino público não somente nos estados como também no Brasil.

Segundo INEP (2009) o índice de abandono é maior que 50\%, em uma turma de 100 alunos matriculados no Ensino Fundamental, apenas 53 conseguem concluí-lo. O MEC mostra que $47 \%$ dos docentes da rede pública que dão aula a $4^{\text {a }}$ série não possuem diploma universitário, mas o que preocupa e falta de verbas para investimento no setor.

De tudo o que é produzido no país, o Brasil só investe no setor de educação menos de $4 \%$ do Produto Interno Bruto (PIB). O presidente da Confederação Nacional dos Trabalhadores em Educação (CNTE) diz que esse valor é ínfimo quando comparado ao valor de $6 \%$ que a Argentina investe com uma população de 45 milhões de habitantes.

Esse vergonhoso valor PIB investido causa os mais baixos níveis de educação quando vemos a avaliação da educação brasileira. $O$ que afeta em primeiro lugar a sala de aula, pois baixos salários são oferecidos para os docentes que se sentem desestimulados e obrigados a exercer jornadas duplas ou triplas para garantir o sustento de sua família.

Na região sul do estado de São Paulo, por exemplo, um docente que leciona a mais de dez anos em cinco escolas diz que a educação é tratada com descaso se compararmos a quantia que recebe um político. E completa que educação tem que está em primeiro lugar de prioridade para que se tenha uma população consciente e preparada para o mercado de trabalho.

Uma boa notícia foi que o Presidente do Brasil assinou um Projeto de Lei no final do ano de 2008, onde o docente tem direito ao piso nacional do magistério da educação básica 
fixado no valor de $\mathrm{R} \$ 950,00$ (novecentos e cinquenta reais). Esse valor passou a valer a partir do mês de janeiro de 2009 (http://www.radioagencianp.com.br/).

Existem ainda muitos setores que estão contestando o Projeto. Para se ter uma idéia ou amostra de como é tratada a educação neste país, a atual secretaria de Educação é uma das principais opositoras. A mesma completa que a educação é mantida para dar conta da demanda de discentes e não para a qualidade de ensino, logo não é prioridade.

Além disso, o sistema pedagógico de ensino necessita de infra-estrutura nas escolas, pois a jornadas excessivas de aulas e a superlotação de sala de aulas prejudica o aprendizado tornando-o inadequado. Em muitas escolas discentes chegam a $8^{\underline{a}}$ séria sem saber ler e escrever adequadamente (http://www.radioagencianp.com.br/).

No estado de São Paulo a avaliação do ensino não é o único fator importante, tem que se pensar também nas condições de trabalho dos docentes e de ensino, como também do aprendizado e da organização curricular. Para se ter uma idéia nos quase 16 anos de governos do PSDB, a avaliação sempre seguiu o resultado e não o processo como um todo, ou seja, não houve uma preocupação com a qualidade de ensino.

Na cidade de Itaquaquecetuba, município do estado de São Paulo, o diretor de uma escola afirma que a proposta educacional do governo exclui e não permite a participação das pessoas que realmente estão envolvidas e comprometidas com o setor de educação. $O$ que nos revela a falta de empenho por nossos governantes.

E finalizando, segundo dados da Câmara de Educação Básica (CEB) do Conselho Nacional de Educação existe uma defasagem de mais de 235 mil docentes no ensino médio assinalada principalmente nas disciplinas de Física, Química, Matemática e Biologia.

\subsubsection{SAÚDE}

A saúde no estado de São Paulo analisada por pesquisadores da USP, UNESP e UNICAMP relacionando as condições de vida (qualidade de habitação, escolaridade e saneamento) e o nível de uso de serviços de saúde entre os anos de 2001 e 2002 nos mostra uma dependência relativa ao nível de escolaridade e renda.

As atividades físicas, por exemplo, de indivíduos com baixa renda são mais ativas no cotidiano e com inclusão de mais esportes na alta renda. Porém, o sedentarismo é alto, aproximadamente $50 \%$ entre os homens e $60 \%$ entre as mulheres. E o consumo de frutas e verduras é maior nas famílias mais escolaridade (CESAR et al., 2005).

A pesquisa de aspectos de saúde publica (epidemiológica) como estilo de vida, mortalidade, morbidade e padrão de uso de serviços são de extrema importância para o planejamento de serviços e investimentos em rede básica de saúde e hospitais. Mas, hoje 
os investimentos para pesquisa nesta área são relativamente altos, porém mal administrados para o atendimento das necessidades da população.

Segundo FELDMAN (2006) a situação do setor de saúde paulista apresenta alguns problemas com o sub-financiamento que ocasiona diversas dificuldades como: má-gestão, sucateamento de equipamentos, atraso tecnológico e, conseqüentemente, o atendimento de baixa qualidade à população.

O autor coloca ainda que o desperdício de dinheiro em programas como o da "Farmácia Popular", o qual o governo vende remédios é vetado pela nossa Constituição e também pelo SUS trazendo sérios problemas de assistência farmacêutica gratuita. E juntamente a esse fato existe a descontinuidade de políticas públicas atreladas aos programas de medicamentos genéricos relacionados no tratamento da AIDS criado pelo exministro da Saúde José Serra.

Atualmente os recursos que deveriam ir para a área da saúde são desviados para o atendimento de outros programas como o da "Fome Zero". Esse desvio é de aproximadamente $R \$ 1,6$ bilhões reduzindo ainda mais os investimentos na melhoria dos recursos a saúde.

O estado de São Paulo é um dos únicos estados da Federação que investe em torno de $12 \%$ dos seus recursos em saúde atendendo a Emenda Constitucional 29. Porém, é necessário também que seja investido mais recursos federais para um a realidade de um estado com mais 40 milhões de habitantes.

O estado de São Paulo chega a aplicar um real a mais a cada real a transferido ao Governo Estadual pelo Governo Federal conforme TABELA 18 abaixo.

TABELA 18 - Recursos financeiros Estaduais e Federais/2005 no estado de São Paulo.

\begin{tabular}{l|r|r|r|r}
\hline \hline \multicolumn{1}{c|}{ AÇÕES } & $\begin{array}{c}\text { Recursos } \\
\text { Federais }\end{array}$ & $\begin{array}{c}\text { Per } \\
\text { Capita }\end{array}$ & $\begin{array}{c}\text { Recursos } \\
\text { Estaduais }\end{array}$ & $\begin{array}{c}\text { Per } \\
\text { Capita }\end{array}$ \\
\hline ATENÇÃO BÁSICA & 915,22 & 22,6 & 813,5 & 20,1 \\
\hline MÉDIA E ALTA COMPLEXIDADE & $3.459,31$ & 85,5 & $3.985,3$ & 98,5 \\
\hline TOTAL & $5.073,93$ & 125,4 & $4.798,8$ & 118,6 \\
\hline \hline
\end{tabular}

FONTE: Recursos Federais - SUSDATUSUS/MS e Estaduais - SIAFEM/SES (2006).

Mas, mesmo assim existe um enorme déficit na área de saúde para ao atendimento da população como a falta de equipamentos para realização de exames (tomógrafos, ressonâncias magnéticas, ecocardiograma, ecodoppler, etc.) entre outros relacionados à falta de leitos e a realização tardia de procedimentos cirúrgicos que por muitas vezes levam o individuo a óbito. 
O Governo do estado de São Paulo tem tentado melhorar esta situação com a criação do Serviço de Apoio a Diagnose e Terapia - SADT através de parcerias com iniciativa privada e filantrópica, convênios e organizações sociais para a implantação de 20 hospitais novos.

Outro investimento do Governo é a criação de Centros Regionais de Especialidades Médicas no Estado com parceria dos municípios. Estes centros terão laboratórios de patologia clinica, radiodiagnóstico, sala para pequenas cirurgias e leitos de repouso, os mesmos serão instalados em diferentes regiões do Estado com uma localização de $100 \mathrm{~km}$ de distância dos demais municípios a serem atendidos (FELDMAN, 2006).

\subsubsection{TRANSPORTE}

De acordo com a Constituição Federal, em seu artigo 182, é obrigatório para cidades com mais de vinte mil habitantes o ordenamento pleno do desenvolvimento das funções sociais da cidade, do bem estar dos habitantes e da garantia da propriedade urbana para o cumprimento da função social.

O estado de São Paulo apresenta vários eixos rodoviários por onde se realiza a dispersão urbano-industrial das indústrias localizadas na Grande São Paulo em direção ao interior como (FIGURA 45):

1) As rodovias Anhanguera-Bandeirantes (SP 330; SP 348), que passam pela Região Metropolitana de Campinas em direção ao centro agroindustrial de Ribeirão Preto, que já conta com 505.012 habitantes.

2) A rodovia Presidente Dutra (BR 116), via de ligação da metrópole paulista com a metrópole carioca, passando pelo Vale do Paraíba, região de importantes centros urbanoindustriais como São José dos Campos (538.909), Jacareí (191.358), Taubaté (244.107) e Guaratinguetá (104.022). São José dos Campos, além de um importante centro aeroespacial, destaca-se na pesquisa científica e tecnológica, sediando renomados institutos como o Instituto Tecnológico da Aeronáutica (ITA) e o Instituto Nacional de Pesquisas Espaciais (INPE).

3) A rodovia Washington Luiz (SP 310), um prolongamento da Anhangüera em direção a São José do Rio Preto (357.862), que passa por núcleos urbano-industriais importantes como Rio Claro (168.087), São Carlos (192.923), Araraquara (181.989), Catanduva (105.771) e outros menores. O destaque é o pólo tecnológico de São Carlos, um importante centro de pesquisa direcionada à engenharia, à física e à química, por intermédio da Universidade Federal de São Carlos (UFSCar) e de um campus da Universidade de São Paulo (USP). Conta, também, com o Parque de Alta Tecnologia de São Carlos, fundado em 1984 e uma incubadora de pequenas empresas criadas em 1986. 
4) A rodovia Castelo Branco (SP 280), que passa por cidades importantes como Sorocaba (494.649) e Itu (135.304) em direção a Botucatu (108.112) e Bauru (315.835), segundo dados do censo demográfico de 2000, do IBGE.

5) Ao longo desses eixos estão também os efeitos negativos do desenvolvimento principalmente problemas decorrentes de infra-estrutura como ausência de aterros sanitários, coleta de lixo, contaminação de mananciais por efluentes industriais, especulação imobiliária levando à segregação sócio - espacial, loteamentos clandestinos e irregulares, entre outros. 


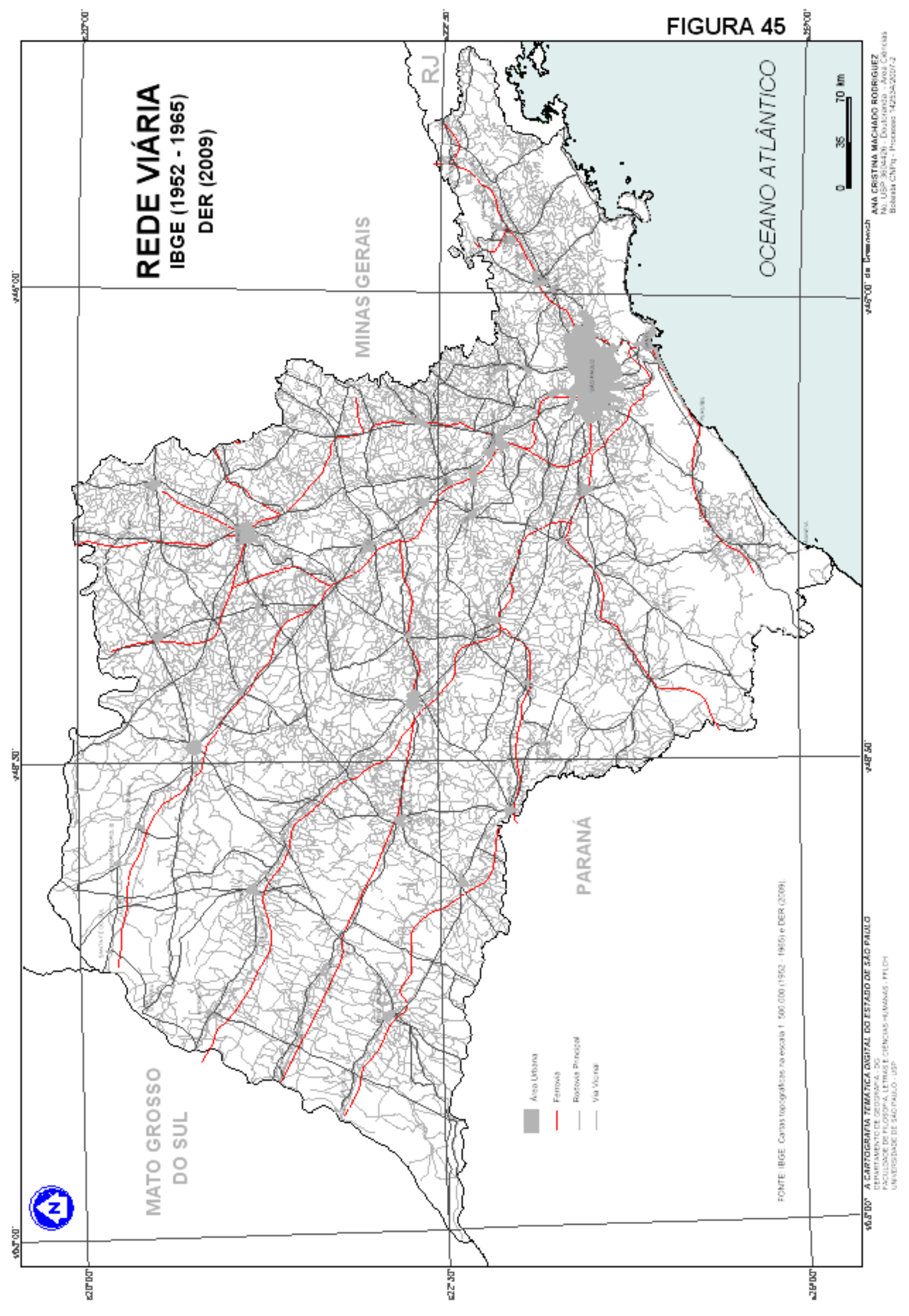


A maioria das ferrovias do estado de São Paulo, após a Segunda Guerra Mundial, foi desativada por falta de adequação técnica, operacional ou física. Assim, com o objetivo de centralizar o transporte, as ferrovias foram unificadas e o governo criou a FEPASA (Ferrovia Paulista S/A) que era constituída por $5.252 \mathrm{~km}$ de linhas, 622 locomotivas, 1.109 carros de passageiros de longo percurso, 116 trens-unidades para transporte urbano e 17.200 vagões (MINISTÉRIO DOS TRANSPORTES, 2003).

Por volta da década de 80 , os investimentos na rede ferroviária cresceram bastante e a média de carga transportada era de aproximadamente 8 milhões por ano em 1971. E já em 1982 esse número cresceu para 23 milhões.

Porém com a ineficiência estatal nos anos 90, o transporte ferroviário se fixou em apenas 18,5 milhões de toneladas diminuído em 30\% depois de três anos. Desta forma, foi inevitável não passar por uma crise ferroviária devido principalmente à má administração da FEPASA.

O estado de São Paulo por sua vez não conseguiu segurar a estatal e a entregou para o Governo Federal em 1997. O que levou a privatização do Conselho Nacional de Desestatização (CND) pela União no ano seguinte.

O leilão das linhas ferroviárias teve como ganhador o grupo Ferrovias, onde a União faz a concessão pelo DOU no. 251-E para a exploração e desenvolvimento do serviço público de transporte ferroviário de carga na Malha Paulista por um prazo de 30 anos e prorrogável por até igual período (MINISTÉRIO DOS TRANSPORTES, 2003).

O grupo Ferrovias liderado pela Ferropasa controla a Ferronorte que liga São Paulo ao Pará e Rondônia; a Novoeste ex-malha oeste que liga Bauru a Corumbá no Mato Grosso do Sul. O Brasil tem aproximadamente $4.000 \mathrm{~km}$ de costas navegáveis e milhares de quilômetros de rios, os trechos mais importantes estão no sul e no sudeste do país.

O estado de São Paulo possui dez (10) terminais hidroviários, os quais são destinados ao transporte aquático de grandes volumes a longas distâncias (TABELA 19). Este tipo de transporte é bastante barato em relação aos transportes rodoviários e ferroviários. O custo do transporte é cobrado por tonelada no embarque e no desembarque.

TABELA 19 - Relação dos Terminais Hidroviários do estado de São Paulo.

\begin{tabular}{l|l}
\hline \hline $\mathbf{N}^{0}$ & \multicolumn{2}{|c}{ TERMINAIS } \\
\hline 01 & ANDRADINA \\
\hline 02 & ANHEMBI \\
\hline 03 & ARAÇATUBA \\
\hline 04 & BARIRI \\
\hline \hline
\end{tabular}




\begin{tabular}{l|l}
\hline \hline 05 & CONCHAS \\
\hline 06 & JAÚ \\
\hline 07 & PANORAMA \\
\hline 08 & PEDERNEIRAS \\
\hline 09 & PRESIDENTE EPITÁCIO \\
\hline 10 & SANTA MARIA DA SERRA \\
\hline \hline
\end{tabular}

FONTE: MINISTÉRIO DOS TRANSPORTES (2008).

\subsubsection{SEGURANCQA PÚBLICA}

A falta de recursos no estado de São Paulo para a segurança pública encontra-se estampado em jornais, revistas e veículos de comunicação. A maioria dos municípios reclama da falta de segurança da população, a qual está associada à segurança social devido à existência de 44 milhões de miseráveis em todo País (AGENDA BRASIL, 2006).

Este quadro propicia para organizações criminosas um crescimento violento vindo a preencher as lacunas da sociedade. Essa condição auxilia também na geração da instabilidade afetando a produtividade das empresas e aumentando custos dos serviços públicos.

A principal medida do governo é a tomada de medidas injetoras de investimentos maciços. Para se ter noção da crise no estado de São Paulo é posta na cadeia cerca de 700 pessoas por mês, o que exige a construção de pelo menos uma penitenciária a cada trinta dias.

Mas, esse é o caminho? A prisão? Não seria melhor criar e cuidar do sistema relativo à penitenciária, pois do contrário, onde as mesmas são construídas sofreriam um choque. É necessário prestar assistência e criar condições nas penitenciarias para que produza e se possa vender essa produção (AGENDA BRASIL, 2006).

Todo esse caos na segurança pública no estado de São Paulo havia sido previsto pelo Conselho Nacional de Política Criminal e Penitenciária. O qual defendia que haveria de se conceder maior autonomia para os municípios e também maior integração entre os órgãos policiais, o sistema penitenciário e a Justiça.

Esta medida do Conselho devolveria a reintegração do controle do estado às amplas áreas das grandes cidades e evitaria o crime organizado. Pois, cabe aos municípios a aplicação de políticas de prevenção e repressão ao crime e á violência (AGENDA BRASIL, 2006). 


\section{IV - CARTOGRAFIA DO USO E COBERTURA DA TERRA DO ESTADO DE SÃO}

PAULO

A Cartografia do uso e cobertura da terra do estado de São Paulo expressará o meio geográfico com tal uso do território, mediante a representação gráfica, uma linguagem vista como um sistema semiológico monossêmico. Para isso contar-se-á com o auxílio dos sistemas de informação geográfica (SIG).

O meio geográfico descrito pela representação em mapa busca compreender e expor a dinâmica existente entre os elementos naturais e sociais. A dinâmica destes elementos pode ser expressa pelos mapas de uso e cobertura da terra. Pois, segundo ROSS (1994) estes mapas podem revelar uma espécie de retrato instantâneo da manifestação dinâmica das relações sócio-econômicas de um território.

Desta forma, foram necessários a aquisição de dados de diversos tipos, formatos e fontes, distribuídos no tempo e no espaço. Mas, estes dados necessitam, primeiramente, de serem corrigidos, organizados e tratados.

\subsection{O MÉTODO DE PESQUISA}

Neste item abordaremos o conjunto de técnicas e práticas envolvidas para o desenvolvimento desta pesquisa. As etapas a serem descritas estão relacionadas com a aquisição, importação e processamentos dos dados.

\subsection{RECURSOS: MATERIAIS, TÉCNICAS E EQUIPAMENTOS}

Para os dados cartográficos descreveremos as suas fontes e escalas. Depois, daremos ênfase às imagens digitais orbitais e de radar com suas respectivas características e formatos. E em seguida os equipamentos utilizados no desenvolvimento da pesquisa.

As cartas topográficas selecionadas para o desenvolvimento deste trabalho de pesquisa estão apresentadas na FIGURA 46 e TABELA 20. A presença de erros na representação do meio geográfico nestas cartas era visível, apesar de seu bom estado de conservação. Um exemplo disso era o rio Paranapanema que iniciava em uma carta e noutra desaparecia totalmente.

Estas cartas topográficas na escala de 1: 500.000 foram encontradas nas Bibliotecas do Instituto Nacional de Pesquisas Espaciais - INPE e na Faculdade de Filosofia, Letras e Ciências Humanas - USP. 


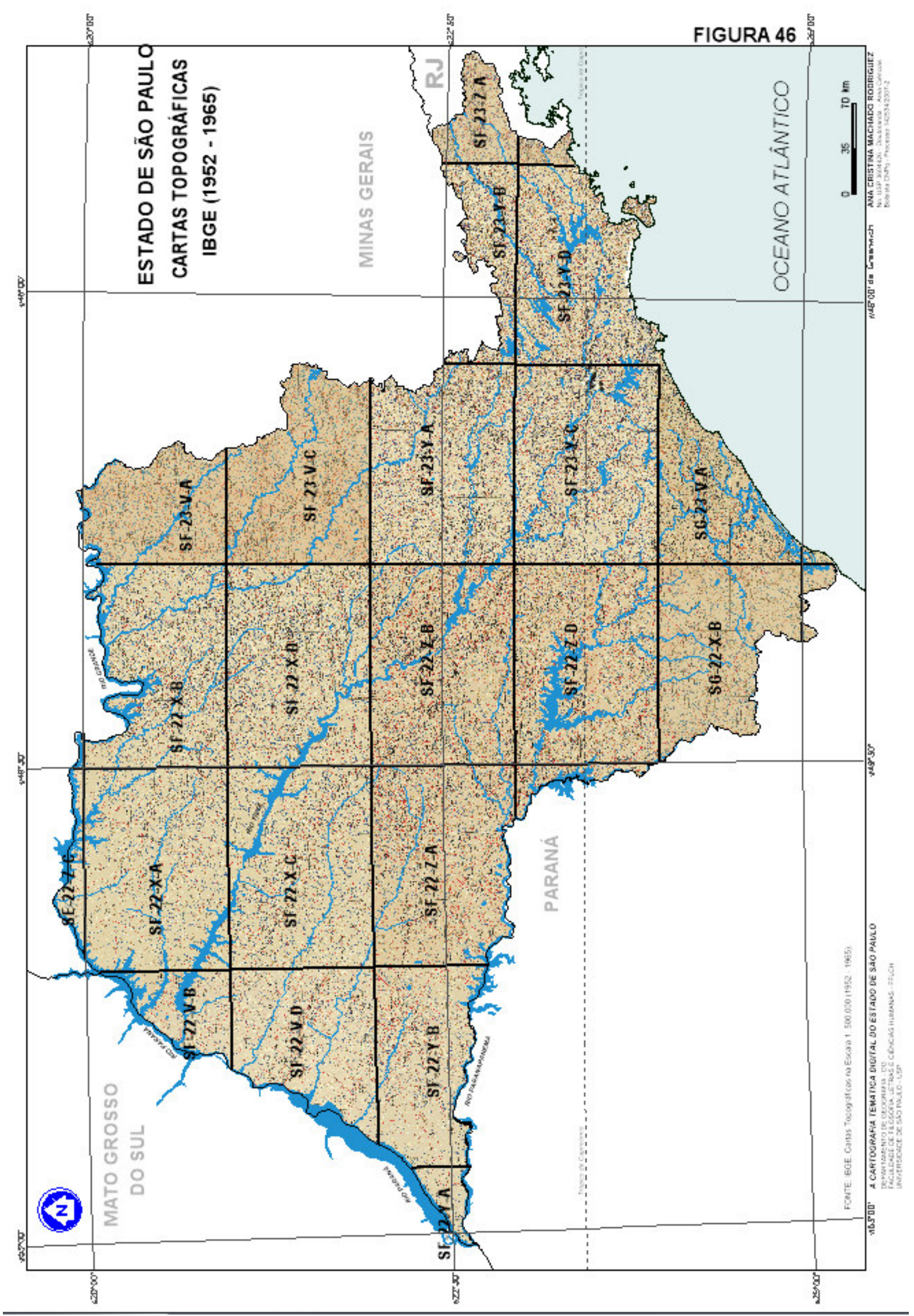


TABELA 20 - Relação de cartas topográficas do estado de São Paulo.

\begin{tabular}{|c|c|c|c|c|c|}
\hline FOLHAS & NOME & ANO & PROJEÇÃO & DATUM & INSTITUIÇÃO \\
\hline SF-22-X & PARANAPANEMA-NE & 1954 & \multirow{4}{*}{ UTM } & \multirow{11}{*}{ SAD 69} & \multirow{11}{*}{ IBGE } \\
\hline SF-22-V & PARANAPANEMA-NO & 1954 & & & \\
\hline SF-22-Y & PARANAPANEMA-SO & 1965 & & & \\
\hline SF-22-Z & PARANAPANEMA-SE & 1953 & & & \\
\hline SE-23-Y & BELO HORIZONTE-SO & 1955 & \multirow{7}{*}{ POLYCONIC } & & \\
\hline SE-22-Z & GOIÂNIA-SE & 1954 & & & \\
\hline SF-23-V & RIO DE JANEIRO-NO & 1955 & & & \\
\hline SF-23-Y & RIO DE JANEIRO-SO & 1961 & & & \\
\hline SF-23-Z & RIO DE JANEIRO-SE & 1959 & & & \\
\hline SG-23-V & IGUAPE-NO & 1963 & & & \\
\hline SG-22-X & CURITIBA-NE & 1952 & & & \\
\hline
\end{tabular}

Do acervo de cartas temáticas em pequena escala (1: 2.500.000) do estado de São Paulo cedido pelo Prof. Marcello Martinelli se utilizou as seguintes: Geologia, Divisão geomorfológica, Unidades de relevo, Bacias hidrográficas, Clima, Cobertura Vegetal Primitiva e Aptidão Climática para a Cafeicultura. Além, destas utilizadas na caracterização da área de estudo, outras como: produção de café, classes de capacidade de uso das terras, uso da terra e revestimento, etc., ajudaram no entendimento e análise usos e coberturas do meio geográfico (TABELA 21).

O acervo é material didático utilizado na sala de aula com alunos de Graduação e Pós-Graduação nas Disciplinas de Cartografia Temática e Ambiental.

TABELA 21 - Relação de mapas temáticos do estado de São Paulo.

\begin{tabular}{l|l|c}
\hline \hline \multicolumn{1}{c|}{ NOME } & \multicolumn{1}{c}{ FONTE } & \multicolumn{1}{c}{ ANO } \\
\hline $\begin{array}{l}\text { GEOLOGIA: UNIDADES } \\
\text { LITOESTRATIGRÁFICAS }\end{array}$ & IPT. Mapa Geológico do Estado de São Paulo. Monografia, (6). & 1981 \\
\hline DIVISÃO GEOMORFOLÓGICA & $\begin{array}{l}\text { Almeida, F. F. M. de Fundamentos Geológicos do Relevo } \\
\text { Paulista. Boletim do IGG, (41). 159-263 }\end{array}$ & 1964 \\
\hline COMPARTIMENTOS DO RELEVO & IBGE. Atlas Nacional do Brasil. Rio de Janeiro. & 2000 \\
\hline BACIAS HIDROGRÁFICAS & IGC. Rede Hidrográfica do Estado de SP. Escala 1:1 000.000 & 1985 \\
\hline CLIMA: TENTATIVA DE & $\begin{array}{l}\text { Monteiro, C. A. F. A dinâmica e as chuvas do Estado de São } \\
\text { CLASSIFICAÇÃO }\end{array}$ & 1973 \\
\hline COBulo. IG-USP & $\begin{array}{l}\text { Troppmair, H. A Cobertura Vegetal Primitiva do Estado de São } \\
\text { Paulo. Biogeografia (1):1-10. }\end{array}$ & 1969 \\
\hline \hline
\end{tabular}




\begin{tabular}{|c|c|c|}
\hline $\begin{array}{l}\text { APTIDÃO CLIMÁTICA PARA A } \\
\text { CAFEICULTURA }\end{array}$ & $\begin{array}{l}\text { SÃO PAULO (ESTADO) Secretaria da Agricultura. Atlas do } \\
\text { zoneamento agrícola do estado de São Paulo. Suplemento do } \\
\text { vol. 2. Campinas, SA, } 1977 .\end{array}$ & 1977 \\
\hline PRODUÇÃO DE CAFÉ & $\begin{array}{l}\text { Anderson, C. Zonas Produtoras de Café. São Paulo, Anderson, } \\
\text { Clayton \& Co., S.A. }\end{array}$ & 1967 \\
\hline $\begin{array}{l}\text { CLASSES DE CAPACIDADE DE } \\
\text { USO DAS TERRAS }\end{array}$ & $\begin{array}{l}\text { Chiarini, J. V. e Donzeli, P. L. Levantamento por } \\
\text { Fotointerpretação das Classes de Capacidade de Uso das } \\
\text { Terras do Estado de São Paulo. Boletim Técnico (3). Campinas, } \\
\text { IAC. }\end{array}$ & 1973 \\
\hline $\begin{array}{l}\text { USO DA TERRA E REVESTIMENTO } \\
\text { DO SOLO (TROPPMAIR 1978-1981) }\end{array}$ & $\begin{array}{l}\text { Troppmair, H. Ecossistemas e Geossistemas do Estado de São } \\
\text { Paulo. Boletim de Geografia Teorética, } 13(25): 27-36\end{array}$ & 1983 \\
\hline $\begin{array}{l}\text { USO DA TERRA E REVESTIMENTO } \\
\text { DO SOLO EM } 1920\end{array}$ & $\begin{array}{l}\text { Estado de São Paulo. Comissão Geográfica e Geológica. Carte } \\
\text { Générale de l'état de São Paulo avec indications sur } \\
\text { l'agriculture, l'industrie et l'élévage. Escala 1:1.500.000. São } \\
\text { Paulo, Uccle-Bruxelas, Patesson. }\end{array}$ & 1920 \\
\hline $\begin{array}{l}\text { COBERTURA VEGETAL NATURAL } \\
\text { FLORESTAS: SITUAÇÃO PRIMITIVA }\end{array}$ & Cavalli, A. C., Guillaumon, J. R. \& Serra, R. & 1973 \\
\hline COBERTURA VEGETAL NATURAL & Instituto Florestal. Inventário Florestal do Estado de SP. & 1993 \\
\hline FRAGMENTOS DE CERRADOS & $\begin{array}{l}\text { São Paulo. Secretaria do Meio Ambiente. Cerrado: Bases para } \\
\text { conservação e uso sustentável das áreas do cerrado do Estado } \\
\text { de SP. São Paulo, SMA. }\end{array}$ & 1995 \\
\hline $\begin{array}{l}\text { DENSIDADE DEMOGRÁFICA } \\
\text { SEGUNDO MUNICÍPIOS }\end{array}$ & $\begin{array}{l}\text { IBGE. Censo Demográfico 2000: Resultados Preliminares, Rio } \\
\text { de Janeiro. }\end{array}$ & 2000 \\
\hline $\begin{array}{l}\text { CLASSIFICAÇÃO DO CLIMA PELO } \\
\text { SISTEMA INTERNACIONAL DE } \\
\text { KÖPPEN }\end{array}$ & $\begin{array}{l}\text { Setzer, J. Atlas Climático e Ecológico do Estado de SP. São } \\
\text { Paulo, CIBPU }\end{array}$ & 1966 \\
\hline UNIDADES PLUVIAIS & $\begin{array}{l}\text { Sant'Anna Neto, J. L. As chuvas do Estado de São Paulo. DG- } \\
\text { FFLCH-USP. }\end{array}$ & 1995 \\
\hline $\begin{array}{l}\text { VARIAÇÕES ESPACIAIS DA } \\
\text { TEMPERATURA }\end{array}$ & $\begin{array}{l}\text { Monteiro, C. A. F. O clima e a organização do espaço no Estado } \\
\text { de SP: Problemas e Perspectivas, IG-USP \& Monteiro, C. A. F. } \\
\text { Variações espaciais de temperatura: tendência média anual e } \\
\text { extremos sazonais. In: Atlas do Estado de São Paulo, IG-USP }\end{array}$ & 1976 \\
\hline UNIDADES GEOTÉCNICAS & $\begin{array}{l}\text { Instituto de Pesquisas Tecnológicas - IPT. Carta Geotécnica do } \\
\text { Estado de São Paulo. São Paulo. }\end{array}$ & 1994 \\
\hline UNIDADES DE RELEVO & $\begin{array}{l}\text { Ross, J. L. S. e Moroz, I. C. Mapa Geomorfológico do Estado de } \\
\text { SP. São Paulo. USP/IPT/FAPESP. }\end{array}$ & 1997 \\
\hline $\begin{array}{l}\text { UNIDADES DE CONSERVAÇÃO } \\
\text { AMBIENTAL }\end{array}$ & $\begin{array}{l}\text { São Paulo. Secretaria do Meio Ambiente. Atlas das Unidades de } \\
\text { Conservação Ambiental do Estado de SP,Parte I e II. São } \\
\text { Paulo, Metalivros/SEMA. }\end{array}$ & 1998 \\
\hline SOLOS & $\begin{array}{l}\text { Oliveira, et alli. Mapa Pedológico do Estado de São Paulo. } \\
\text { Campinas, Rio de Janeiro, IA/EMBRAPA. }\end{array}$ & 1999 \\
\hline
\end{tabular}


Foram reunidas as seguintes imagens digitais para o desenvolvimento desta pesquisa, a saber:

1) Mosaico de imagens do satélite TERRA/MODIS (MOD13) do período de 27 julho à 11 agosto de 2009 na resolução espacial de 250 metros.

2) Mosaico de imagens do satélite CBERS/CCD de resolução espacial 90 metros (reamostradas) do ano 2008 pertencentes ao Projeto CANASAT (RUDORFF et al., 2009).

3) Produto GEOCOVER com resolução espacial de 14,5 metros.

4) Algumas imagens do Google Earth (IKONOS e QuickBird).

5) Imagem do SRTM (Shuttle Radar Topographic Mission) com resolução espacial de 90 metros.

Utilizou-se o notebook Intel Core 2 Duo Windows Vista Home Premium Service Pack 2 com disco de 230 Gigabyte, uma impressora Epson Stylus Multiuso com Xerox e Scanner.

Os softwares utilizados são o SPRING (Sistema de Processamento de Informações Georeferenciadas) versão 4.2, desenvolvido pelo Instituto Nacional de Pesquisas Espaciais - INPE e o ENVI (The Environment for Visualizing Images) versão 3.6, desenvolvido pela RSI (Research Systems) distribuído no Brasil pela ITT (Visual Information Solutions). Estes foram escolhidos pela nossa familiaridade no manuseio de suas ferramentas de processamento digital, construção de mapas, entre outros aplicativos.

\subsection{PROCEDIMENTOS}

Após a descrição dos dados cartográficos e temáticos, das imagens digitais orbitais e de radar, e dos equipamentos, compete se falar dos procedimentos de digitalização, de importação e de processamento digital.

\subsubsection{DIGITALIZAÇÃO E IMPORTAÇÃO}

No software SPRING, com a criação do Banco de dados, os elementos constituintes do meio físico e social (vetorial e raster) foram digitalizados e/ou importados. Esta entrada de dados no software permitiu a reunião de informações ( $\mathrm{Pl}$ 's) como geologia, geomorfologia, clima, entre outros para a análise e construção do Mapa de uso e cobertura da terra.

As cartas topográficas e os mapas temáticos foram escanerizados com resolução de 300 dpi's ( $x$ e y) para a obtenção de uma imagem final de 40 metros de resolução espacial. Estas no formato TIFF, foram convertidas para GRIB no Módulo IMPIMA do software SPRING para posterior georreferenciamento e importação para o Banco de Dados. 
Para o georreferenciamento das cartas topográficas se executou a aquisição de 40 pontos de controle distribuídos uniformemente via teclado do computador para cada carta. Após, esse registro as mesmas foram importadas para o Banco de Dados resultando em onze (11) planos de informação. Ao final, estes foram mosaicados para um único $\mathrm{PI}$.

Por conseguinte, com base neste único PI se executou o georreferenciamento dos mapas temáticos. E com a digitalização destes se obteve dados da Hidrografia, Rede viária, Rede ferroviária, Geologia, Divisão geomorfológica, Bacias hidrográficas, Clima, entre outros.

As curvas de nível, o mapa de relevo e a declividade foram extraídos e processados a partir dos dados disponibilizados pela EMBRAPA <http://relevobr.cnpm.embrapa.br/s obtidos da USGS (2008).

\subsubsection{PROCESSAMENTO DOS DADOS ORBITAIS E DE RADAR}

As imagens do sensor MODIS foram eleitas por terem uma cobertura homogênea da área de estudo e a probabilidade na obtenção de imagens livres de nuvens, além da escala de trabalho. Estas imagens são superiores em contrapartida aos outros sensores de SR devido a sua alta frequência temporal (2 dias). Segundo STRAHLER et al., (1996) o MODIS possui uma alta sensibilidade radiométrica, logo uma excelente resposta para cada banda.

As imagens do satélite TERRA/MODIS (MOD13) foram adquiridas no formato HDF (Hierarquical Data Format) em dois Tiles $h 13 v 11$ e $h 13 v 10$ na projeção sinosoidal. Onde, o tile $h 13 v 11$ cobre $97 \%$ e os $3 \%$ restantes foram adquiridos e recortados do $h 13 v 10$ para completar a área de estudo. O produto MOD13 utilizado corresponde aos Índices de vegetação. As composições (mosaicos) destes índices representam às variações ocorridas na vegetação num período de 16 dias.

O MOD13 é um produto indicado para comparar a partir de dados consistentes os dados temporais e espaciais sobre as condições da vegetação global, fazer a monitoração da atividade fotossintética da vegetação para averiguar a detecção de mudanças e também nas interpretações biofísicas e fenológicas (HUETE et al., 2002).

O processamento destas imagens foi realizado no software ENVI no aplicativo MODIS Reprojection Toolkit disponibilizado gratuitamente na página da ITT. Este aplicativo lê os produtos MODIS em formato HDF e na projeção sinusoidal possibilitando ao usuário a escolha das bandas de seu interesse, inclusive de seus metadados. A leitura e a re-projeção são transformadas para sistemas mais conhecidos como UTM, Policônica, entre outros.

Em seguida as imagens do sensor MODIS foram inseridas no Banco de Dados do software SPRING. As mesmas não foram georreferenciadas, pois elas já possuíam um pré- 
processamento como: correção atmosférica, radiométrica e geométrica. TELLES et al., (1995) comenta que os dados deste sensor são corrigidos por técnica paramétrica utilizando pontos de controle somente para a remoção das direções tendenciosas. A orientação a partir da Terra é obtida pelos sensores a bordo do satélite.

O arquivo vetorial contendo o limite do estado de São Paulo adquirido do IBGE (2005) se encontrava disponível no formato shape file do ARCVIEW. O mesmo foi importado para o Banco de dados para a execução do recorte das imagens MODIS.

Desta forma, após a redução da área de processamento se aplicou o Modelo linear de mistura espectral (SHIMABUKURO et al., 1997) nas imagens MODIS com o objetivo de identificar as diversas formas de uso e cobertura da terra. A incidência de uma grande diversidade de mistura de alvos identificados no estado de São Paulo estabeleceu a utilização de tal técnica, assim como estudos pesquisados sobre o modelo.

As assinaturas espectrais dos principais alvos como solo, vegetação e água/sombra foram capturados a partir do cursor do mouse do computador (dado bruto), com a intenção de se individualizar as suas respectivas proporções. A partir daí, aplicou-se o critério dos Mínimos quadrados com restrições indicado quando se quer estimar as proporções de três alvos ou componentes. Obtiveram-se como produtos três novas bandas a partir das originais, as imagens-fração solo, vegetação e água/sombra.

Por conseguinte, aplicou-se a segmentação nas imagens-fração, tal procedimento é indicado antes da classificação digital, pois nos permite homogeneizar e extrair as regiões a serem identificadas e classificadas para os diferentes usos e coberturas da terra.

A segmentação também é uma técnica de processamento de análise de imagens que possibilita a divisão em regiões espectralmente homogêneas. Para o estado de São Paulo se executou o segmentador de Crescimento de regiões que agrega os pixels com propriedades similares em conjuntos denominados regiões (polígonos), cujas bordas definem os seus contornos. A extração destas bordas foi executada pelo algoritmo de ERTHAL et al., (1991).

Para a aplicação desse segmentador definimos dois limiares, o de similaridade e o de área (BINS, 1996). Estes limiares determinam a precisão e a área mínima a ser individualizada, respectivamente. Para a área de estudo foram executados testes que nos indicaram os valores de 8 para similaridade e de 25 para área. Esses valores foram os que melhor representaram as áreas contendo vegetação, áreas urbanizadas, solo exposto, corpos d’água (rios, lagos, etc.), áreas alagadas, entre outros.

Para a extração de regiões nas imagens-fração se criou um arquivo de contexto para o armazenamento das informações sobre o tipo de classificação por regiões, as bandas ou Rodríguez, A. C. M. 
imagens utilizadas e a imagem segmentada. Nessa extração o algoritmo utilizado extrai os atributos estatísticos como médias e matrizes de covariância do conjunto de regiões definido na fase de segmentação.

Com a extração das regiões aplicou-se a classificação supervisionada pelo classificador Bhattacharrya com limiar de aceitação de $90 \%$. A supervisão ou indicação de amostras (treinamento) para as classes temáticas foram criteriosamente interpretadas e obedeceram aos critérios utilizados por ANDERSON (1982). O autor define que os elementos na área são reconhecidos por sua textura, estrutura, forma, sombra, tonalidade/cor e padrão, além das características espectrais de absorção e reflexão dos materiais. Além, deste se utilizou também o método de VENEZIANI \& ANJOS (1982) aprimorado de ANDERSON (1982) para a fotointerpretação de áreas no Brasil.

Após, a classificação da imagem segmentada realizou-se o mapeamento para a associação de cada uma das classes temáticas a uma classe de uso e cobertura da terra. Estas classes foram determinadas para o estado de São Paulo no banco de dados a partir da análise e estudo dos mapeamentos utilizados por KELLER (1969), ANDERSON (1971) e et al.,(1979), JENSEN (1983) e TROPPMAIR (1983).

As classes temáticas criadas foram num total de quatro (4): Remanescentes de formações arbóreas, arbustivas e reflorestamento; Cultura de cana de açúcar; Culturas diversas; Áreas urbanas e solo exposto; Outros usos e Corpos d'àgua. Essas classes foram escolhidas por serem as mais representativas do meio geográfico do estado de São Paulo. Existiam outras que devido à escala de trabalho não achamos conveniente incluí-las.

As formas uso e cobertura discriminadas apresentaram erros de classificação digital quando comparadas e analisadas visualmente com a imagem original do MODIS (composições coloridas R2G3B1 e R3G2B1).

Os erros foram dirimidos com a aplicação da edição matricial. Pois, o classificador utilizado mesmo com a intervenção do fotointérprete é limitado devido às semelhanças de respostas espectrais de alvos diferentes, escolha de limiares de similaridade e área mínima na fase de segmentação. Assim, após a edição os erros de omissão e inclusão foram minimizados resultando em um mapeamento de boa acurácia.

No entanto, ainda para averiguarmos acerca deste mapeamento decidimos utilizar os índices de vegetação NDVI (Normalized Difference Vegetation Index) e o EVI (Enhanced Vegetation Index). Convém este procedimento, pois estes índices são importantes e complementares para os estudos globais de vegetação e, além disso, eles nos fornecem informações mais precisas sobre a detecção de mudanças vegetais, assim como dos parâmetros biofísicos do dossel. $\mathrm{E}$ a presença de maior contraste na região do Rodríguez, A. C. M. 
infravermelho próximo e menor contraste no vermelho são indicadores de alto vigor ou grande densidade de cobertura vegetal.

O NDVI é sensível à clorofila e o EVI às variações na resposta estrutural do dossel incluindo o índice de área foliar (LAI), a fisionomia da planta e também a arquitetura do dossel. Os dois índices para o estado de São Paulo se complementaram e ajudaram na validação das classes temáticas criadas a partir das imagens-fração.

O fatiamento em intervalos de classes de uso e cobertura da terra destes índices teve como objetivo identificar as áreas com e sem vegetação. No fatiamento em uma escala linear de medida com valores de 1 a -1 de variação dos índices escolhemos as classes de vegetação, solo e água similar as componentes propostas no modelo linear de mistura espectral. Tal escolha nos favoreceu quando analisamos as áreas classificadas obtidas pelo mapa de uso e cobertura da terra do estado.

Os altos valores dos índices correspondem à presença de densidade de fitomassa verde, por tanto à medida que aumenta a quantidade de vegetação aumenta também a reflexão na banda do infravermelho próximo e diminui consideravelmente a reflexão na banda do vermelho fazendo com que o aumento da razão seja potencializado realçando assim a vegetação (KAZMIERCZAK, 1996).

A análise dos índices de vegetação em conjunto com as imagens-fração nos possibilitou averiguar e delimitar a vegetação, a qual em destaque o maior bioma presente no estado de São Paulo, a Mata Atlântica. Assim, como na identificação de outros usos e coberturas da terra.

Além desta, uma forma de uso e cobertura da terra delimitada de grande impacto no estado de São Paulo é o cultivo de cana-de-açúcar. As áreas mapeadas por estas cultura foram bem evidentes nas imagens-fração e confirmadas pelos dados fornecidos por RUDORFF et al., (2009) referentes ao ano-safra de 2007/2008 obtidos do Projeto CANASAT. Este projeto foi desenvolvido pelo INPE em conjunto com a União da Agroindústria Canavieira (ÚNICA) com o Centro de Tecnologia Canavieira (CTC) e com o Centro de Estudos Avançados em Economia Aplicada (CEPEA).

Os dados do SRTM correspondem a uma imagem em níveis de cinza juntamente com uma grade numérica no formato GEOTIFF. Estes dados foram processados no ENVI e posteriormente importadas para o SPRING, e recortadas com o vetor de limite do estado.

A grade retangular representada por valores mínimos e máximos de altitude permitiu modelar a forma de relevo resultando na representação da superfície física do estado de São Paulo. E também possibilitou a construção do relevo contendo as cotas altimétricas e a declividade. 
As classes de declividade em porcentagem de inclinação obedeceram à metodologia desenvolvida por DE BIASI (1992) e LEPSCH (1983). Estas foram criadas considerando o relevo e às características de uso, as altitudes encontradas na área e também a legislação ambiental vigente para os diferentes tipos de uso e ocupação (TABELA 22).

TABELA 22 - Classes de declividade com características de relevo e uso.

\begin{tabular}{c|c|c|l}
\hline \hline \multirow{2}{*}{ CLASSES } & \multirow{2}{*}{$\begin{array}{c}\text { LIMITES } \\
\text { (\%) }\end{array}$} & \multicolumn{2}{|c}{ CARACTERÍSTICAS QUANTO AO } \\
\cline { 3 - 4 } & $<5$ & RELEVO & \multicolumn{1}{c}{ USO } \\
\hline 2 & $5-15$ & Plano Suave Ondulado & $\begin{array}{l}\text { Limite Urbano Industrial utilizado em Planejamento } \\
\text { Urbano. }\end{array}$ \\
\hline 3 & $15-30$ & Inclinado & $\begin{array}{l}\text { Intervalo definido como máximo utilizável para a } \\
\text { Mecanização Agrícola. }\end{array}$ \\
\hline \multirow{2}{*}{3} & $>30$ & $\begin{array}{l}\text { Intervalo estabelecido pela Legislação Federal no } \\
\text { 6766/79 (Lei Lehmann), a qual define o limite } \\
\text { máximo para a Urbanização sem qualquer restrição, } \\
\text { onde toda e qualquer forma de parcelamento deve } \\
\text { atender exigências especificas. }\end{array}$ \\
\hline \hline
\end{tabular}

FONTE: Adaptado de DE BIASI (1992) \& LEPSCH (1983).

Para a obtenção do relevo e da declividade executou-se o fatiamento da imagem do SRTM para identificar com exatidão os valores da grade retangular de MNT. No SPRING os intervalos de classe (cotas altimétricas) foram obtidos com a aplicação do modo fixo para determinar a equidistribuição manual dos intervalos entre as cotas de acordo com o passo fornecido. Anteriormente, criou-se a categoria e o PI temático contendo as classes préestabelecidas com suas respectivas cores anexadas.

\subsubsection{TRABALHO DE LABORATÓRIO}

Decidiu-se realizar apenas o trabalho de laboratório devido às inúmeras imagens de diferentes sensores e satélites adquiridos para a confrontação de dúvidas acerca do mapeamento realizado com as imagens MODIS. Os resultados alcançados com a classificação supervisionada nas imagens-fração para obtenção do mapa de uso e cobertura da terra foram conferidos pelos índices de vegetação do NDVI e EVI para dirimir os erros de rotulação nas classes temáticas de uso e cobertura da terra.

As imagens do CBERS e o produto GEOCOVER foram utilizados também com o intuito de se averiguar e dirimir possíveis dúvidas acerca do mapeamento de uso e 
cobertura da terra durante a fase de edição matricial. Mas, algumas dúvidas ainda referentes ao mapeamento só foram sanadas com o apoio de imagens do Google Earth.

A exatidão do mapeamento de uso e cobertura da terra pelo algoritmo de Bhattacharrya (ERTHAL et al., 1991) foi satisfatório devido principalmente ao numero reduzido de erros de polígonos classificados. E segundo COUTINHO et al. (1998) a exatidão de um mapeamento automático é bastante considerável quando comparados aos métodos convencionais de interpretação visual. Os autores apresentam uma porcentagem de $80 \%$ de acertos de polígonos mapeados demonstrando a eficiência comprovada dos métodos, procedimentos e resultados adotados.

Todos os procedimentos executados neste trabalho de pesquisa encontram-se organizados na FIGURA 47.

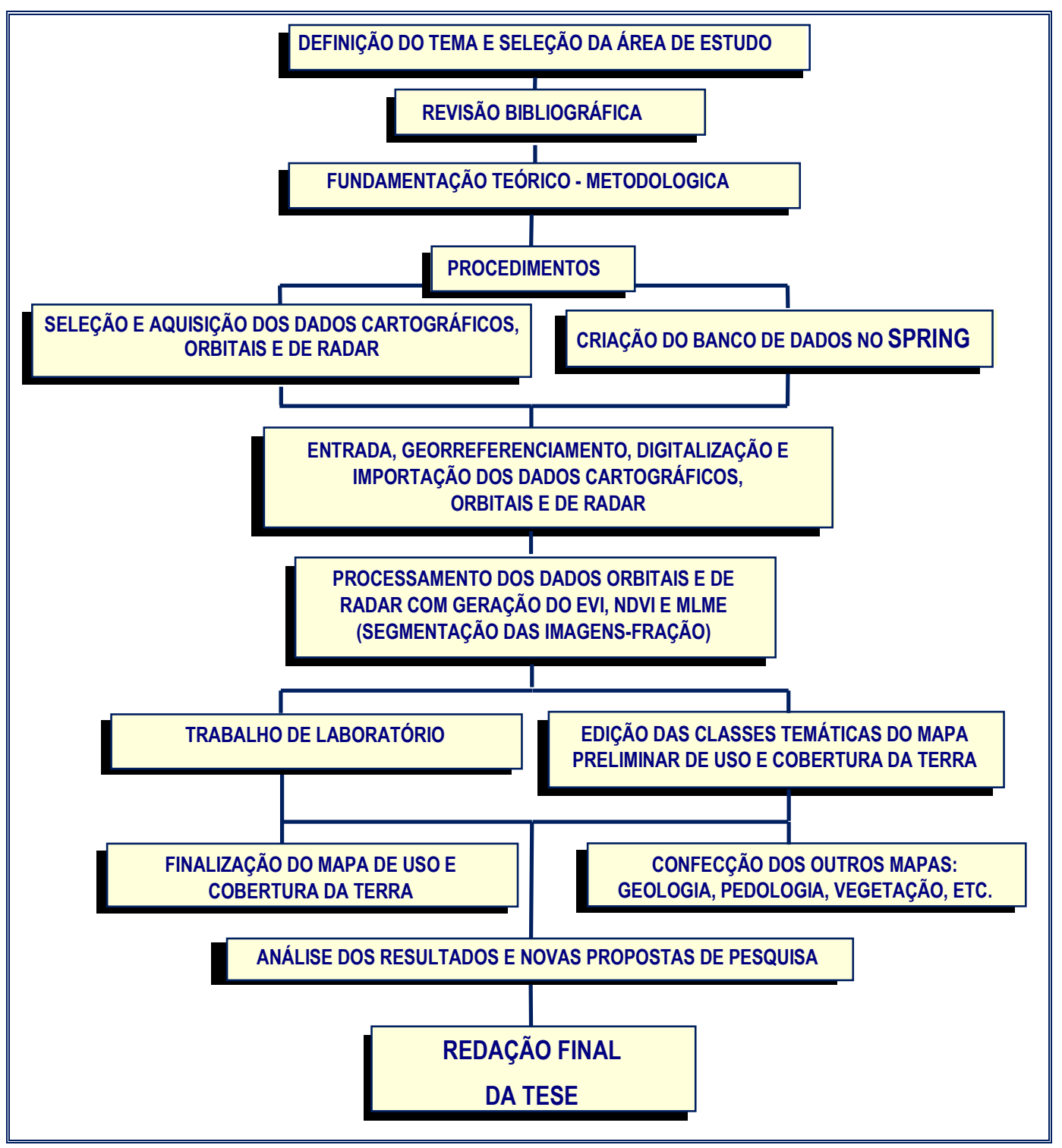

FIGURA 47 - Fluxograma de atividades. 


\section{V - RESULTADOS E DISCUSSÕES}

O Mapa de uso de cobertura da terra nos indica a distribuição espacial da variedade de modalidades de tais aspectos e suas características atuais. Tais formas correspondem aos aspectos mais importantes indicativos do conhecimento da situação sócio-ambiental de uma nação, pois os mesmos nos dispõem de informações sobre suas atividades, e assim são bases para a tomada de decisões. Segundo ANDERSON (1982), trata-se de um mapa que reflete os processos de ocupação ocorridos no meio geográfico, assim como os problemas ambientais atuais que nele existem e precisam ser compreendidos.

No caso do estado de São Paulo pela escala estabelecida de estudo e período analisado de 16 dias (27 de julho a 11 de agosto) este mapeamento foi estático e generalizado, porém nos deram um perfil da localização e identificação dos usos praticados em consonância com as relações sócio-econômicas.

A boa precisão alcançada neste mapeamento pelo uso do sensor MODIS se deve em grande parte às características inovadoras dos produtos de SR. Segundo RUDORFF et al., (2007) os estudos empregados para o mapeamento de distintas classes de uso e cobertura necessitam de uma alta repetitividade à atrelada a boa qualidade geométrica e correção atmosférica presentes nos dados do sensor MODIS.

A contribuição do SIG no desenvolvimento e obtenção do mapa de uso e cobertura da terra proporcionou uma rápida e eficiente elaboração deste trabalho de pesquisa. Mas, é importante frisar que a metodologia e os critérios estabelecidos utilizados com o uso do software não poderiam ser mais bem aproveitados sem a interferência de um fotointérprete habilitado e experiente no levantamento do uso e cobertura da terra.

A distribuição das modalidades de uso e cobertura da terra está associada principalmente aos fatores climáticos, às características fisiográficas do terreno e à atividade humana. Pois, o meio geográfico não é estático, ele vive em continua transformação quer seja pelo meio ambiente ou pela ação antrópica alterando os ecossistemas que nela habitam.

\subsection{RELEVO E DECLIVIDADE DO ESTADO DE SÃO PAULO}

Com o intuito de retratar o relevo que predomina na região de estudo apresentamos as principais classes de altitude distribuídas espacialmente pelas curvas de nível com eqüidistância de 150 metros (FIGURA 48). Tais dados são oriundos do produto SRTM disponibilizado pela USGS com resolução espacial de 90 metros. 


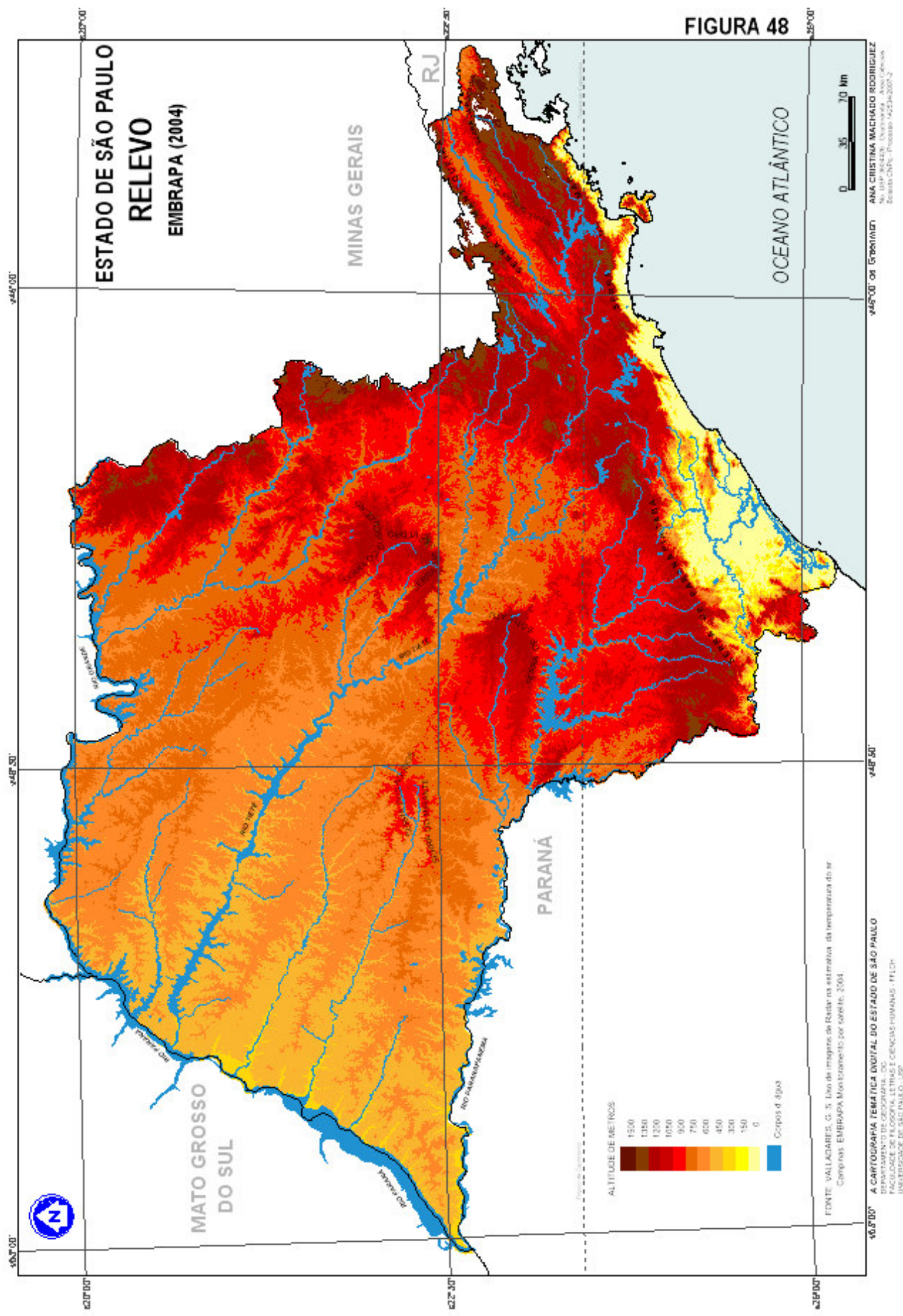


A legenda contendo as faixas de altitude deste mapa foi elaborada utilizando a representação do relevo por cores hipsométricas. Segundo MARTINELLI (2009) este tipo de representação para o relevo exige como ponto de partida uma escolha adequada de faixas de altitude. Elas devem ser consideradas em função do modelado geral da região estudada, de modo à melhor caracterizar os grandes compartimentos topográficos que se distinguem na paisagem como: as planícies, os planaltos e as montanhas porventura nela contidas, completa o autor.

A gama de cores em ordem visual crescente empregada foi indo das mais claras às mais escuras, acompanhando a progressão para o alto das cotas de altitude.

Segundo BERTIN (1971) apud MARTINELLI (2009) trata-se de um mapa com relações de ordem entre as faixas de altitude. A representação deu ao relevo uma visão de conjunto da imagem de sua configuração plástica. É um mapa altimétrico do relevo. A visualização do mapa tem uma expressão da informação em nível ordenado, não se trata de uma relação quantitativa. A noção do valor de altitude é percebida exclusivamente pela leitura da legenda.

Desta forma, as planícies do estado de São Paulo encontram-se abaixo de 150 metros de altitude e as áreas mais altas com valores superiores a 1500 metros. Segundo GUIMARÃES (1943) apud AB'SÁBER (2004)(FIGURA 49): a maior parte do território do estado encontra-se com altitudes de 300 a 900 metros (74\%). Das quais se incluem alguns dos mais deprimidos e importantes compartimentos do Planalto Atlântico em São Paulo como o Médio Vale Superior do Paraíba e a região de São Paulo, além da totalidade da Depressão Periférica paulista e extensas áreas de chapadões arenítico-basálticos do Oeste Paulista.

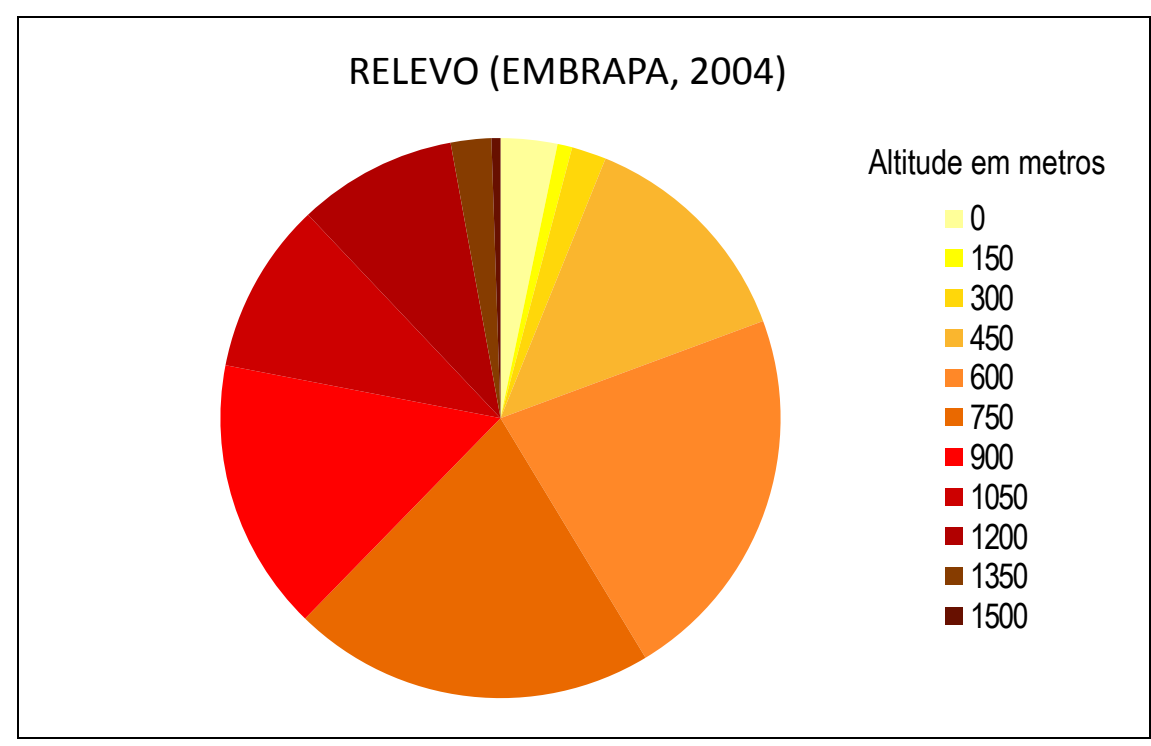

FIGURA 49 - Classes de altitude do estado de São Paulo. 
As pequenas porções dos alinhamentos mais elevados das cuestas basálticas escapam desse quadro mediano de altitudes, caracterizando assim, a amplitude topográfica geral dos diversos patamares internos do Planalto Meridional do Brasil, em São Paulo, completam os autores.

As baixadas costeiras de origem flúvio-marinha, as encostas baixas das ilhas e os sopés das escarpas da Serra do Mar e encostas dos outeiros, morros e baixos maciços isolados das planícies costeiras paulistas encontram-se com altitudes abaixo de 150 metros.

As altitudes de 200 e 300 metros (4\%) englobam a pequena área das baixas vertentes da Serra do Mar e a área dos flancos de maciços isolados das baixadas e das ilhas continentais paulistas. Situando-se ainda uma pequena área das barrancas e dos terraços da calha maior do rio Paraná.

As altitudes superiores a 900 metros (20\%) se destacam nos altos blocos de planaltos soerguidos da Bocaina e de Campos do Jordão (1628 metros), as escarpas e esporões sul-orientais e ocidentais da Mantiqueira, os espigões mais elevados das regiões serranas do Alto Paraíba, Alto Tietê e Alto do Ribeira, as cristas das montanhas rejuvenescidas semi-apalachianas da série São Roque, alguns trechos do reverso continental da Serra do Mar e da Serra da Paranapiacaba, assim como os altos maciços da Ilha de São Sebastião e da Serra dos Itatins.

Além, do mapa de relevo se achou conveniente elaborar também o de declividade para facilitar a visualização do grau de inclinação do relevo em intervalos de classes: menos de $5,0 \%$; de 5,1 a $15,0 \%$; de 15,1 a $30,0 \%$ e mais de $30,0 \%$ (FIGURA 50 ).

Este mapa nos possibilitou uma análise integrada ao mapa de uso de cobertura da terra para obter medidas da interferência antrópica (sociedade). Tal procedimento nos ajudou no entendimento das feições identificadas atreladas a fotointerpretação dos tipos de uso e cobertura existentes na área de estudo. Na verdade vimos que em áreas de maiores declives a cobertura vegetal tem sido poupada inclusive pelas leis de conservação.

Os remanescentes com maior área significativa foram encontrados principalmente nas grandes amplitudes altimétricas e com alto grau de inclinação das vertentes. Estes estando localizados no Parque Estadual da Serra do Mar sofrem naturalmente com ação das águas fluviais e pluviais vindo a se agravar pela interferência antrópica sem seu estatuto legal de preservação. 


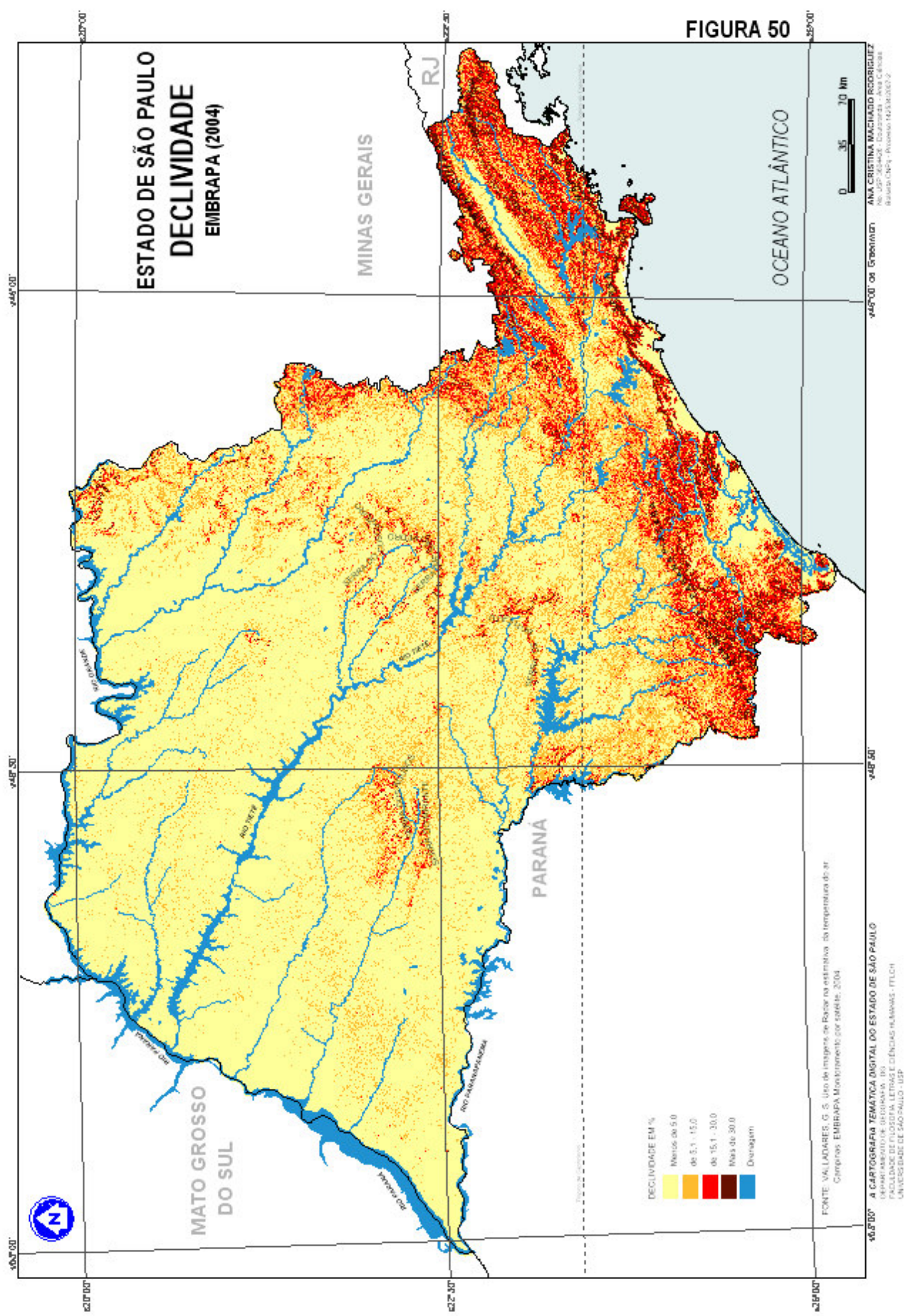


Na elaboração desta legenda se utilizou a representação por classes de declividade, atribuindo-Ihes uma ordem visual crescente, do claro para o escuro. Para tal efeito elegemos cores claras para as declividades suaves e escuras atribuídas às vertentes mais íngremes. Desta forma, o método nos reforçou a construção da imagem e assim houve um impacto instantâneo do conjunto do relevo paulista, valorizando o mapa em termos didáticospedagógicos (MARTINELLI, 2007).

Com base em ROSS (1994), as áreas com declividades inferiores a 5,0\% (muito fraca) compreendem $72 \%$ da área total do estado. Nestas áreas a ocupação urbana deve seguir um planejamento de infra-estrutura adequado devido ao risco de inundação fluvial.

As declividades de 5,1 a 15\% (fraca) com 18\% têm indicação para ocupação urbana e agricultura por práticas simples de conservação do solo. E as com 15,1 a 30\% (Média) com $8 \%$ são áreas que tem incidência de riscos geotécnicos como a erosão caso não se tenha medidas preventivas quanto ao assentamento desordenado (Lei Lehmann Legislação Federal no. 6766/79). A agricultura do tipo mecanizada nestas áreas necessita de práticas complexas de conservação do solo (FIGURA 51).

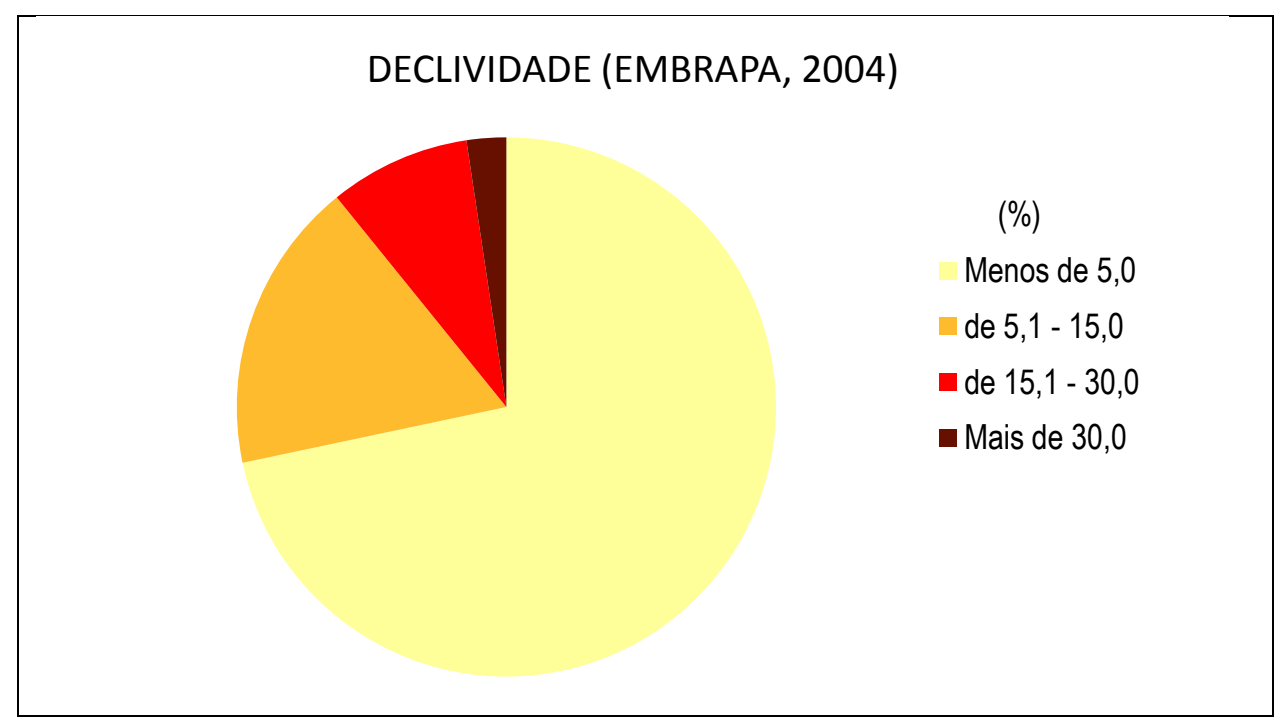

FIGURA 51 - Classes de declividade do estado de São Paulo.

Enquanto que as áreas com declives superiores a 30,0\% (forte e muito forte) fazem parte de $2 \%$ da área de estudo, as quais são inadequadas a qualquer modalidade de uso quer seja urbano ou agricultável devido a riscos de escorregamentos e intensificação de processos erosivos por atividades antrópicas ou naturais.

A maioria destas áreas se encontra protegida pelo Código Florestal (art. 10), a qual proíbe a derrubada de florestas, exceto no caso à extração de toros que é aceita ou tolerável quando em regime de utilização racional vise rendimentos permanentes. 
O Parque da Serra do Mar é uma destas áreas com finalidades para atividades turísticas, recreativas, educativas e/ou esportivas com prévio planejamento de áreas de visitação, com estabelecimento de trilhas mediante um estudo de capacidade de transporte e também de possíveis impactos causados no meio ambiente.

\subsection{INDICES DE VEGETAÇÃO: EVI E NDVI DO ESTADO DE SÃO PAULO}

Os índices EVI e NDVI (FIGURA 52 e 53) contribuíram significativamente para uma melhor distinção da classe relativa aos remanescentes da cobertura vegetal no Mapa de uso de cobertura da terra elaborado a partir das imagens-fração.

A escala linear de medida utilizada nos índices variou entre $-1 \mathrm{a}+1$. Onde, quanto mais próximo de 1 mais presente foram as áreas vegetadas e próximo a 0 (zero) correspondeu a ausência destas, como no caso de corpos d'água ou de áreas urbanas.

Os índices quando apresentam altos valores traduzem literalmente à presença de grande densidade de fitomassa verde. Pois, segundo KAZMIERCZAK (1996) à medida que aumenta a quantidade de vegetação aumenta também a reflexão na banda do infravermelho próximo e diminui consideravelmente a reflexão na banda do vermelho fazendo com que o aumento da razão seja potencializado realçando assim a vegetação.

Desta forma, observou-se que os índices apresentaram certa similaridade quando escalonados para a vegetação, outros usos, área urbana, solo exposto e corpos água. No entanto, o EVI nos identificou muito melhor a vegetação do que o NDVI. Não fizemos a separação das fisionomias vegetais como: a mata, restinga, capoeira, reflorestamento, cerrados, campos, vegetação de várzea e mangue devido à escala de trabalho adotada e também aos valores de índices escalonados nos produtos NDVI e EVI.

Entende-se que essa característica do EVI está associada à redução na influência da atmosfera pela inclusão da banda azul no cálculo do índice (KAUFMAN \& TANRÉ, 1992). Mas, segundo LIU e HUETE (1995) tanto a influência da atmosfera como a do solo devem ser anuladas simultaneamente devido às mesmas serem interativas. Assim, achamos conveniente também gerar o NDVI, o qual nos forneceu auxílio na fotointerpretação da vegetação para a área de estudo. 


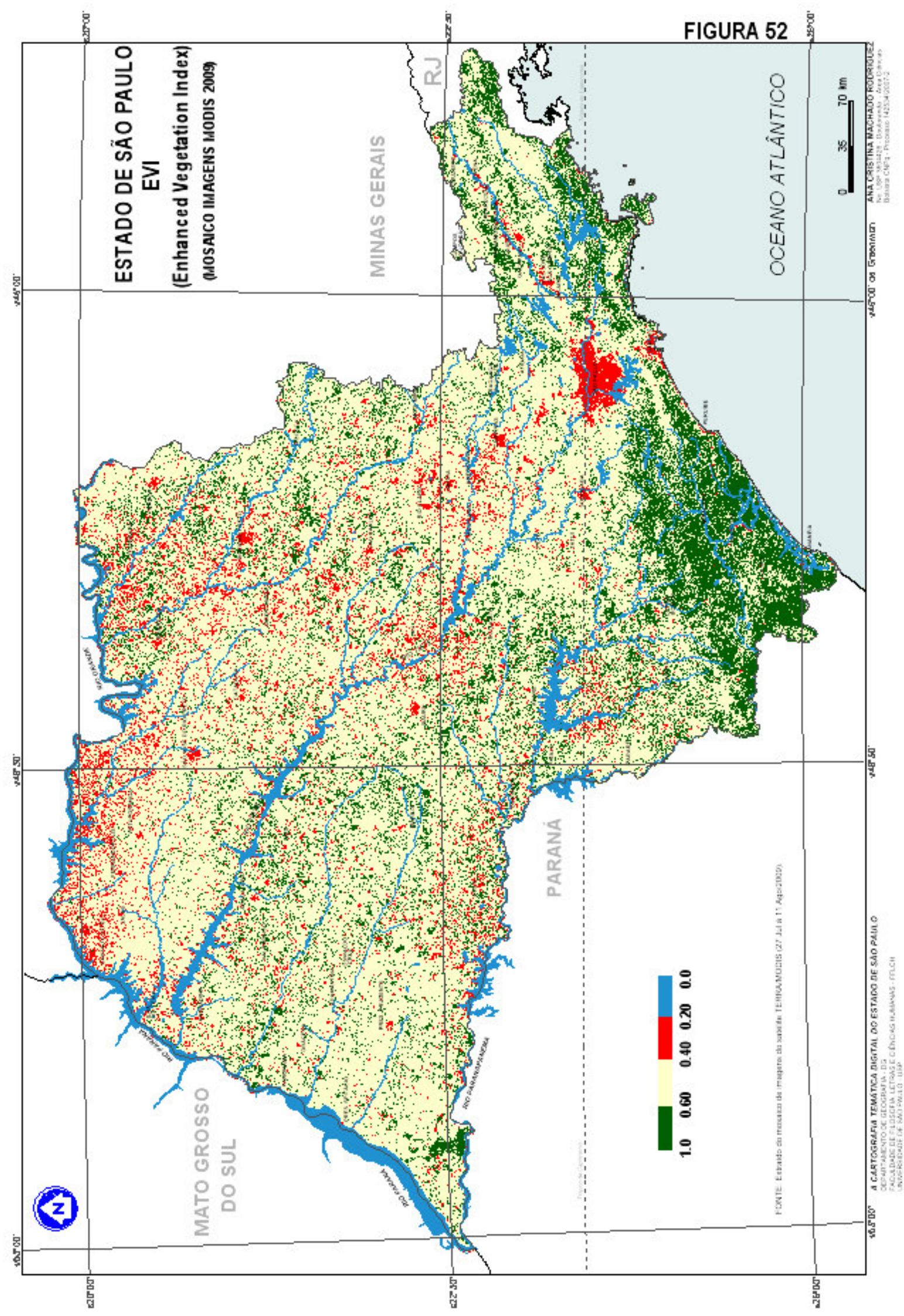




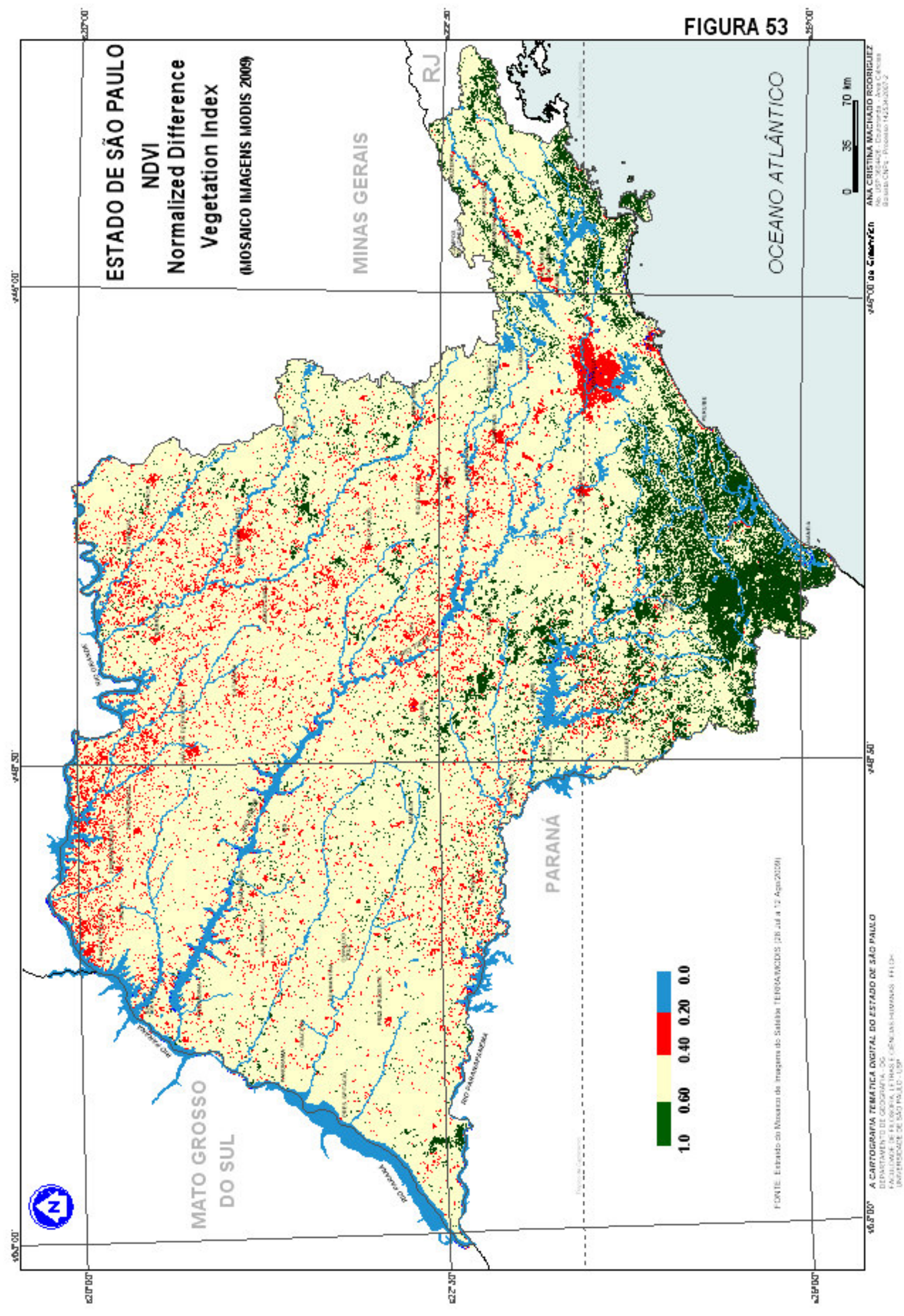


O NDVI gera um índice mais saturado e não reduz a influência da atmosfera como o EVI, por isso algumas fisionomias vegetais não foram identificadas adequadamente. No entanto, quanto às áreas de reflorestamento em comparação ao EVI, o NDVI se apresentou eficaz. Elas são visualmente nítidas no NDVI localizadas principalmente próximo aos municípios de Botucatu e Avaré (FIGURA 54).

$\mathrm{Na}$ fase de fotointerpretação nos apoiamos nas imagens do CBERS e do Google EARTH para confirmamos a ocorrência das áreas de reflorestamento. Na FIGURA 54 apresentamos uma das amostras utilizadas tanto para a fase de treinamento do classificador Bhattacharrya quanto para a edição matricial.

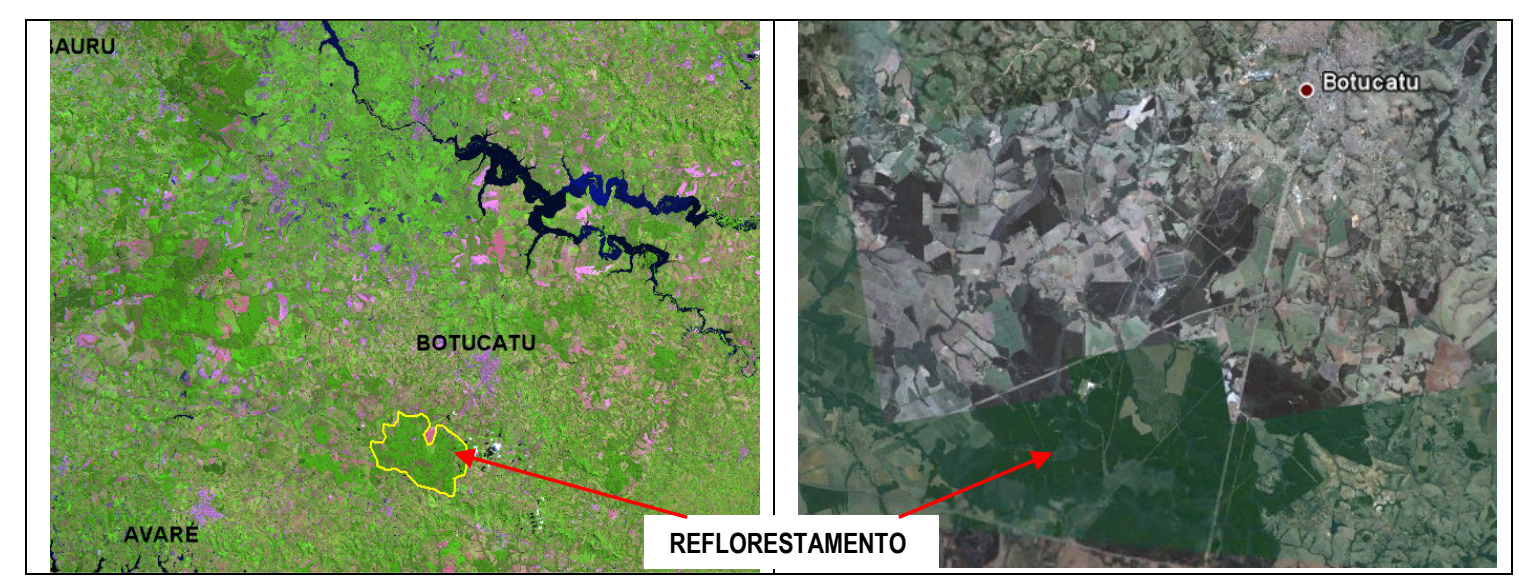

FIGURA 54 - Reflorestamento nas Imagens CBERS e do Google EARTH do estado de São Paulo.

Os remanescentes da cobertura vegetal natural do estado estão localizados espacialmente ao longo da costa e são também encontrados nas Serras do Mar e da Mantiqueira. Eles tiveram uma melhor classificação no EVI do que no NDVI. E ademais o resultado da classificação Bhattacharrya utilizada nas imagens-fração se aproximou mais do obtido pelo EVI.

Os remanescentes da faixa litorânea do estado têm se mantido devido exclusivamente à declividade e ás unidades de conservação. Estes são constituídos por florestas do domínio da Mata Atlântica compreendidos desde o litoral Norte a partir da divisa com o estado do Rio de Janeiro até o litoral Sul onde estão os municípios de Peruíbe e Pedro de Toledo.

Para exemplificar uma das amostras de remanescentes coletadas na etapa de treinamento mostramos a FIGURA 55. Nesta se utilizou também o Google EARTH em destaque o município de Campos do Jordão com declividade superior a 30\%. 


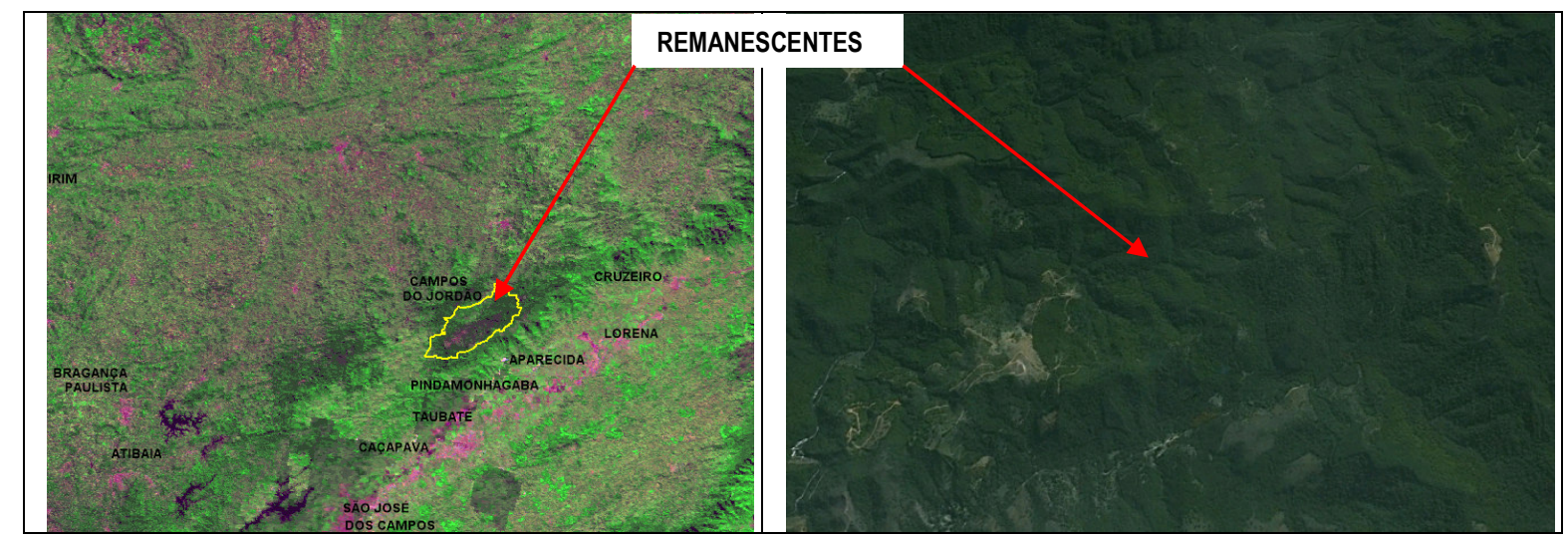

FIGURA 55 - Remanescentes nas Imagens MODIS e do Google EARTH do estado de São Paulo.

As áreas urbanas identificadas nos índices apresentaram confusão com áreas de solo exposto e algumas de preparo para plantio. Esse problema se deve ao escalonamento dos valores dos índices que poderiam ser mais refinados. Ou seja, a escala de valores utilizada foi propositadamente fatiada com objetivo de classificar áreas com e sem vegetação. Tal procedimento pretendeu auxiliar na escolha de amostras e na edição matricial do mapa de uso e cobertura da terra.

Já os corpos d'água foram confundidos nos dois índices por áreas urbanas, as quais se apresentam com alta concentração de sombras, principalmente nas edificações do centro do município de São Paulo. Esta confusão nas amostras foi percebida claramente na imagem-fração água/sombra, porém nossa experiência como fotointérprete e o apoio dos dados da rede hidrográfica, da localização das sedes municipais, assim como da relação lógica dos cursos d'água e estradas nos possibilitou a correta definição destas classes.

\subsection{USO E COBERTURA DA TERRA DO ESTADO DE SÃO PAULO}

O conhecimento das modalidades de uso e cobertura da terra do estado de São Paulo nos faz compreender a atual situação socioeconômica e ambiental da região. Pois, a transformação do espaço pode gerar benefícios a sociedade, assim como a própria destruição de seus recursos naturais.

As classes de uso e cobertura da terra foram identificadas e delimitadas em função das características naturais, da ocupação da região e da escala de trabalho, a qual não nos permitiu a inserção de níveis mais detalhados de fotointepretação. Assim, como se baseou nos mapeamentos realizados por KELLER (1969), ANDERSON (1971) e et al.,(1979), JENSEN (1983) e TROPPMAIR (1983), onde decidimos por apresentar as seguintes classes: 1) Remanescentes de formações arbóreas, arbustivas e reflorestamento; 2) Cultura de cana-de-açúcar; 3) Culturas diversas; 4) Área urbana e solo exposto; 5) Outros usos; e 6) Corpos d'água (FIGURA 56). 


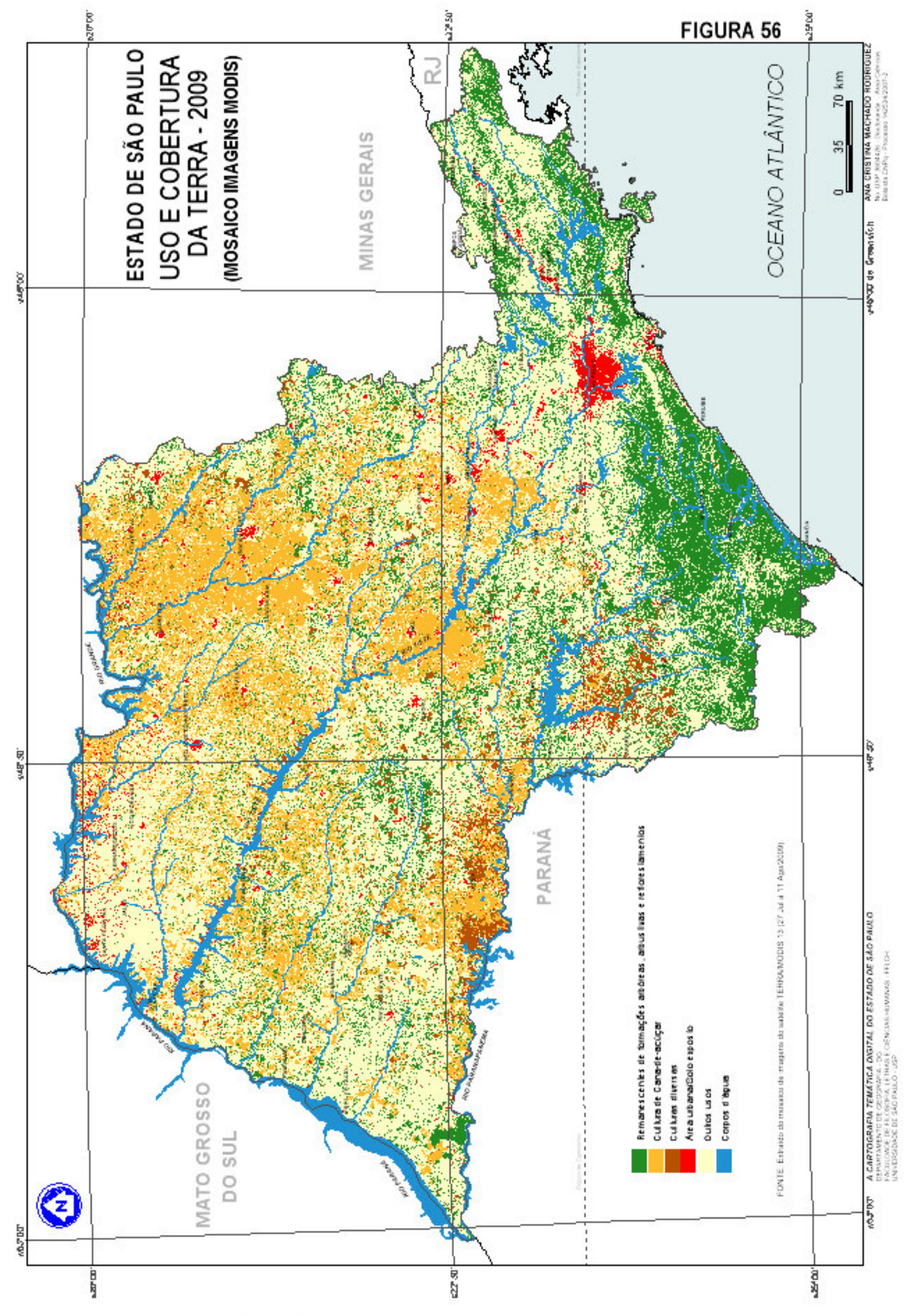


Além, dos autores descritos, a legenda deste mapa e a dos índices de vegetação foram elaboradas também a partir de KONDRACKI \& OSTROWSKI (1980) que usa as cores para a caracterização de regiões fisiográficas. Eles destacam que em uma área com poucas alterações a cor indicada seria o verde enquanto que o amarelo e o vermelho destacam as mais alteradas como as aglomerações urbanas.

Já para as áreas de cultura o mais indicado são às gradações de amarelo compondo uma propriedade ordenada desses elementos considerando a semiologia gráfica. As áreas urbanas, na cor vermelha, não acompanham um raciocínio ordenado, pois se trata de outra informação nos levando a uma caracterização da propriedade qualitativa da legenda.

A classificação dos remanescentes nas imagens-fração teve auxilio dos índices EVI e NDVI como mencionado anteriormente. Eles se apresentam com 19\% do estado e neles estão concentrados as seguintes fisionomias vegetais: mata, restinga, capoeira, reflorestamento, cerrados, campos, vegetação de várzea e mangue (FIGURA 57).

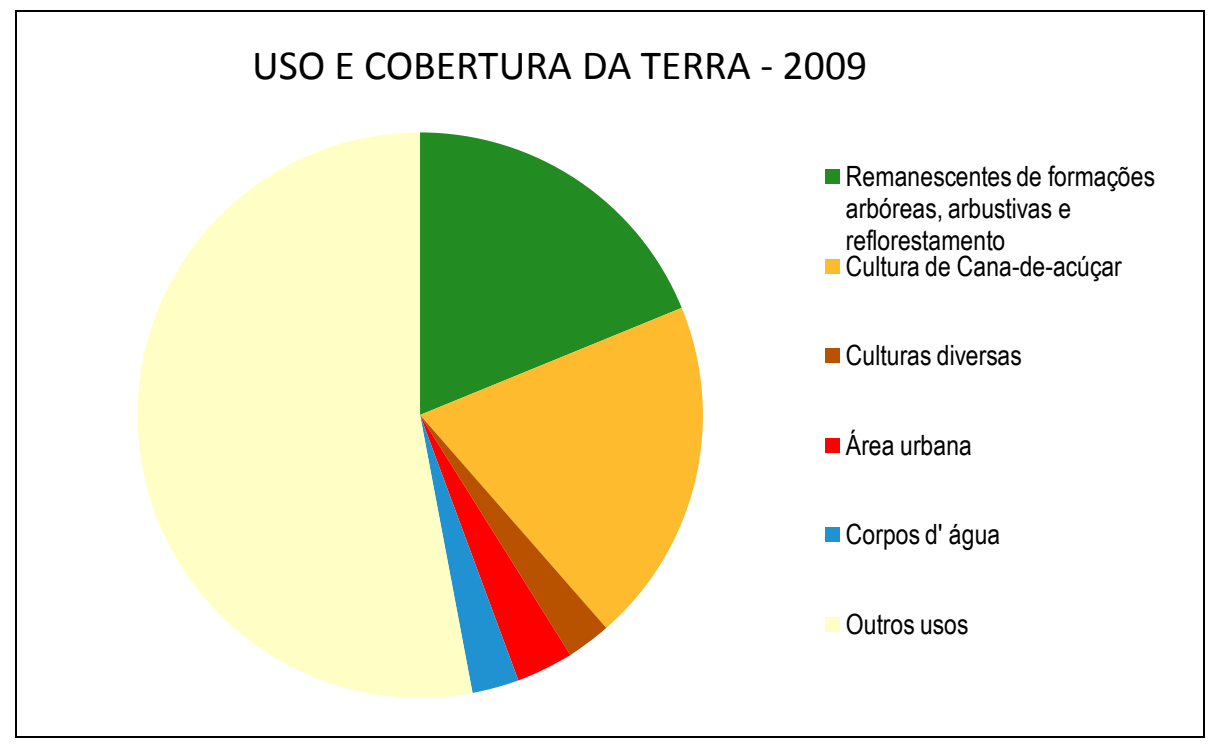

FIGURA 57 - Classes de uso e cobertura da terra do estado de São Paulo.

As áreas de cerrado foram incluídas na classe temática de remanescentes, mas achamos importante destacar que o bioma savana é um dos mais ameaçados no estado de São Paulo devido ao cultivo da cana-de-açúcar. Segundo KRONKA et al.(2005) a drástica redução desse bioma vem ocorrendo desde 1962 (FIGURA 58). Hoje estes remanescentes encontram-se extremamente fragmentadas e compreende menos de $17 \%$ da área total. 


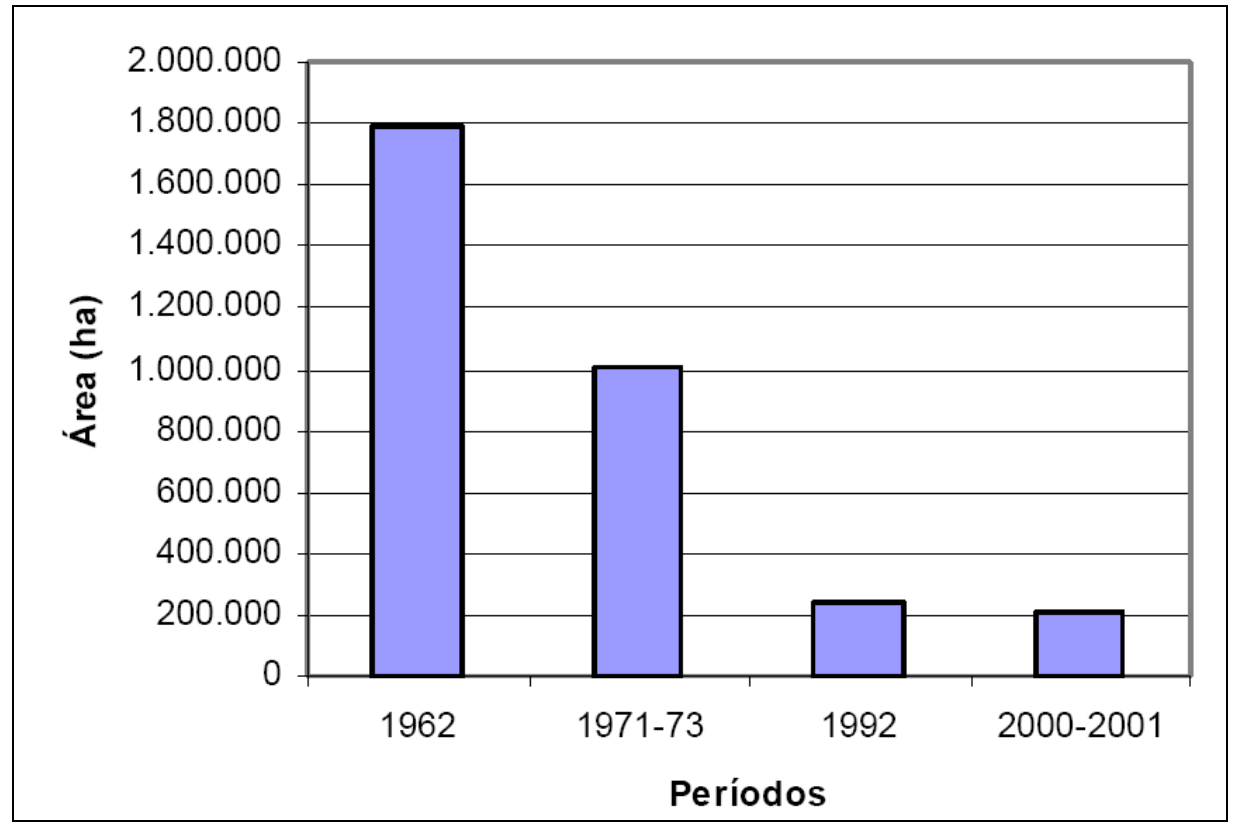

FIGURA 58 - Comparação das áreas totais de cerrado no estado de São Paulo.

FONTE: KRONKA et al.(2005).

As áreas com a cultura de cana-de-açúcar somaram $20 \%$ do estado e foram classificadas nas imagens-fração utilizando como referência os dados fornecidos por RUDORFF et al., (2009) referentes ao ano-safra de 2007/2008 do Projeto CANASAT.

Nos índices de vegetação EVI e NDVI a cultura de cana-de-açúcar foi confundida com áreas urbanas/solo exposto devido ao período de colheita. Pois, o período de aquisição do mosaico MODIS foi de julho a agosto, o qual a cana estava sendo colhida.

As classes de cana-de-açúcar apresentaram resposta espectral muito semelhante ao solo exposto quando as áreas de cana foram cortadas e o solo ficou desnudo, ou ainda quando o solo exposto recebeu os restos da palha seca após o corte.

No estado de São Paulo essa cultura tem se desenvolvido muito rapidamente chegando próxima ao percentual de áreas obtidas por remanescentes. O grande avanço agrícola visa atender a demanda por etanol, o que destaca o estado em âmbito nacional.

O crescimento desta cultura vem se destacado desde 1962 no interior do estado devido principalmente a presença aos solos férteis com baixa pluviosidade e de topografia suave que favorece uma menor erosão no lençol freático. Segundo a CEPAGRI (2006) a região tropical chuvosa com inverno seco e mês mais frio com temperaturas médias superiores a $18^{\circ} \mathrm{C}$ e precipitação inferior a $60 \mathrm{~mm}$ no mês mais seco são as condições propicias para essa cultura. 
Em 1962, Piracicaba era um dos principais municípios cultivadores da cana-deaçúcar, além de Araraquara que no ano 1972 para 1984 dobrou sua produção (INSTITUTO FLORESTAL, 2005).

Atualmente, os principais municípios do estado com maior área de cultivo de canade-açúcar são: Piracicaba, Paraguaçu Paulista, Jaboticabal, Guaíra, Araraquara, Barretos, Jaú, Batatais, Lençóis Paulista, Morro Agudo, Agudo, Paulistânia, Euclides da Cunha Paulista, Mirante do Paranapanema e Piquerobi.

No Brasil, o estado de São Paulo se destaca com a maior produção de cana-deaçúcar, 59\% do total nacional. Onde, 91,3\% são destinados ao setor sucroalcooleiro mantendo o mercado mundial ao longo do ano devido às safras alternadas (CONAB, 2008).

As amostras de cana-de-açúcar eleitas para o treinamento e edição se apresentaram bem organizadas nas imagens-fração, além da identificação no Google EARTH (FIGURA 59). Elas apresentaram na análise das amostras um desempenho médio de 99,96\%.

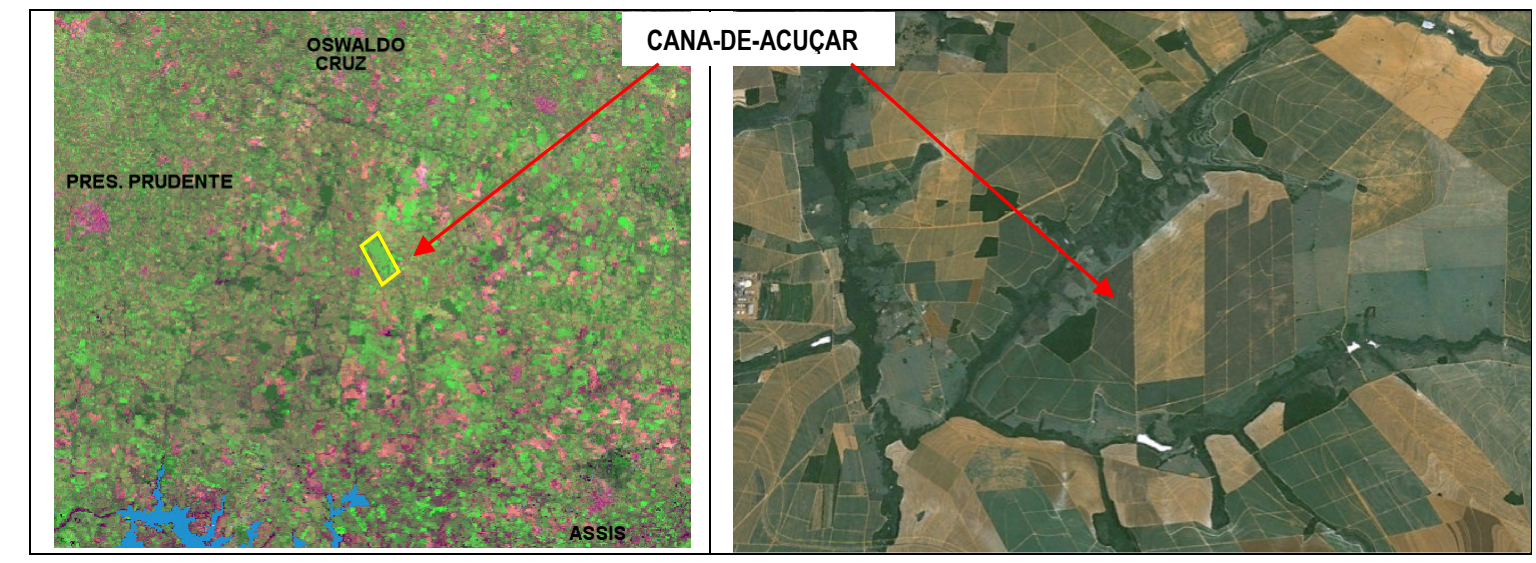

FIGURA 59 - Cana-de-açúcar nas imagens MODIS e do Google EARTH do estado de São Paulo.

A presença da imensa mancha de cultivo da cana-de-açúcar observada no mapa de uso e cobertura da terra nos dar indícios de uma evidente transformação do espaço geográfico paulista, numa corrida frenética para a produção do bio-combustível. Pois, segundo o Projeto CANASAT (INPE), entre os anos de 2003 e 2007, a produção desta cultura saltou de, aproximadamente, 3.000 .000 ha (hectares) para 4.250.000 ha.

As implicações decorrentes deste desacelerado crescimento agrícola tende a refletir enormemente no meio ambiente esgotando o solo e os recursos hídricos por conta do lançamento de defensivos entre outros insumos agrícolas. Segundo o Zonemamento Agroambiental elaborado pelas secretarias do Meio Ambiente e da Agricultura e Abastecimento apoiado pelo Governo, esta produção deve permanecer acelerada, pois ainda existem terras adequadas para o cultivo da cana-de-açúcar (CONAB, 2009). 
Segundo AGUIAR et al. (2009) o cultivo desta cultura vem se tornando tão intensiva no estado de São Paulo que ela vem substituindo a floresta, o pasto, o reflorestamento e as culturas de milho e citrus analisados por imagens TM/Landsat (20 metros de resolução espacial) nos anos de 2003 e 2008 (FIGURA 60).

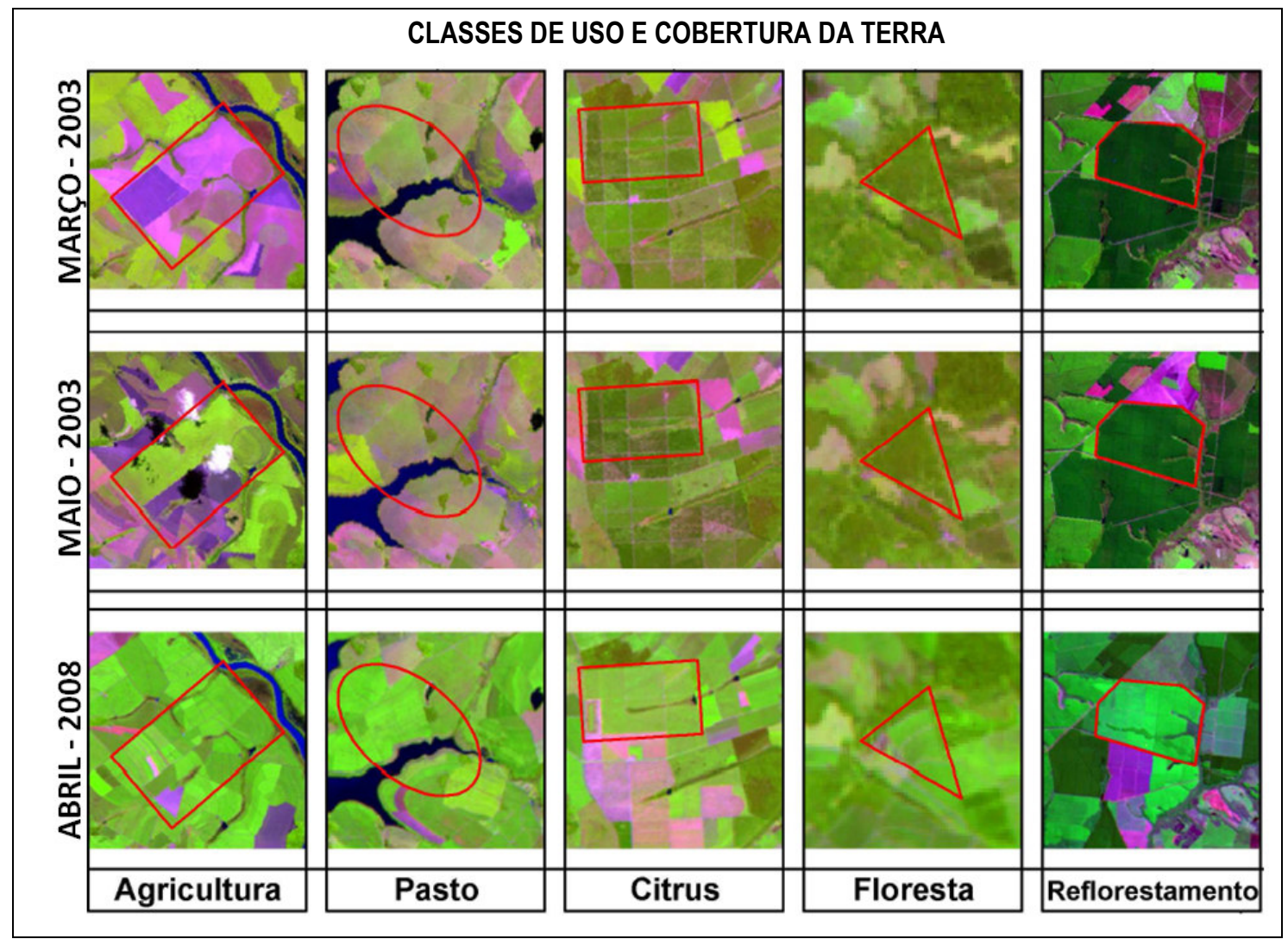

FIGURA 60 - Tipos de uso e cobertura da terra em imagens TM/Landsat no estado de São Paulo.

FONTE: AGUIAR et al.(2009).

Na FIGURA 60 observamos que a classe temática de Agricultura que trata das áreas cultivadas e preparadas para o cultivo se apresentam na data 1 como solo exposto, na data 2 como milho safrinha. E em 2008 (data 3) como plantio da cana-de-açúcar em fase de crescimento avançado se diferenciando das outras culturas pela presença de carreadores de talhões.

A classe temática do Pasto incluindo a pastagem antrópica e natural se apresenta no período de 2003 por vegetação e solo, e na data 3 (2008) é substituída pela cana-de-açúcar. O Citrus com os cultivos de laranja, tangerina e limas existentes no período de 2003 foram substituídos pela cana em 2008.

A Floresta compreendida por áreas de matas ciliares e florestas (independente do estágio de sucessão) é encontrada perfeitamente nos meses de 2003, e em 2008 verifica-se a substituição também pela cana-de-açúcar. O Reflorestamento com pinus e eucalyptus bem presente no ano de 2003 é convertido para o cultivo da cana em 2008. 
A expansão desta cultura na região oeste do estado tem ocorrido principalmente em áreas de pastagem. Enquanto que no centro-norte e na divisa com o estado do Paraná a transformação tem ocorrido sobre outras culturas agrícolas. No município de Barretos, região norte do estado, as plantações de citrus cederam lugar para a cana (CONAB, 2008).

A produção desta cultura pelo exposto tende a crescer muito mais, fazendo-nos perceber que o poder do capital privado atrelado ao governo é um dos principais fatores na configuração e transformação do espaço paulista. O cenário socioeconômico atual privilegiado pela disponibilidade financeira intervém diretamente na expansão agrícola, a qual é de responsabilidade da sociedade (homem) agente modificador do espaço hoje e ao longo dos anos.

No mapa de uso e cobertura da terra as culturas diversas como soja, milho, citrus entre outras se apresentaram com $2 \%$. Elas foram identificadas próximas ao limite com estado do Paraná. Nas imagens-fração estas culturas foram difíceis de serem destacadas devido às mesmas concentrarem pequenas áreas em contrapartida com o dado do sensor MODIS na resolução de 250 metros (fator escala).

As áreas urbanas perfizeram 3\% da área total do estado e foram identificadas nas imagens-fração com melhor consistência do que nos índices de vegetação. Para isso nos apoiamos na rede viária e na divisão municipal.

Nas áreas de corpos d'água existiu confusão com as áreas urbanas, como mencionado anteriormente. Tal confusão encontrada nas imagens-fração foi atribuída à semelhança na resposta espectral. Os corpos d'água apresentaram $3 \%$ da área de estudo.

Diante dos resultados apresentados, pode-se concluir que o estado de São Paulo encontra-se numa contínua transformação do espaço geográfico por áreas agrícolas que visam o setor econômico. As consequências desta expansão agrícola inviabilizam a produção de outras culturas que estão sendo substituídas pela cana-de-açúcar que no momento representam maior rentabilidade, assim como causam problemas aos recursos naturais afetando enormemente o equilíbrio ambiental dos ecossistemas como no caso dos remanescentes de cerrados entre outros. 


\section{VI - CONSIDERAÇÕES FINAIS E SUGESTÕES}

O conhecimento das atuais modalidades de uso e cobertura da terra do estado de São Paulo nos forneceu a real situação de como os espaços geográficos vêm sendo ocupados. Além, do aumento significativo e progressivo da atual expansão agrícola por conta da demanda por etanol segundo (RUDORFF et al., 2004). Salientamos que no estado o setor sucroalcooleiro conta com uma produção de 59,9\% direcionada exclusivamente para a fabricação de bicombustível.

O Zoneamento Agroambiental elaborado pelas secretarias do Meio Ambiente e da Agricultura e Abastecimento como instrumento de planejamento para o setor sucroalcooleiro para um desenvolvimento sustentável da cana-de-açúcar no estado de São Paulo pretende reduzir os riscos climáticos, indicar as regiões e épocas favoráveis para a produção desta cultura com maior rentabilidade e menores riscos. Entretanto, a mesma não prevê os prejuízos e desequilíbrios acarretados ao meio ambiente. O fator desgaste do solo, contaminação dos recursos hídricos pelos insumos agrícolas, a escassez de outros alimentos devido ao valor de mercado da cana entre outros aspectos da qualidade de vida da população afetada pela queima da palha e emissão de gases na produção do etanol.

O processo de expansão agrícola entre outros nos faz repensar de quanta tecnologia necessitamos para o desenvolvimento da sociedade e ao alcançá-la de como fragilizamos e esgotamos os nossos recursos naturais. O homem desde sua existência sempre esteve à frente das transformações do meio ambiente trazendo melhorias para a sociedade e nem sempre previu os problemas e conseqüências destas interferências no equilíbrio ambiental. Ressaltamos que as mudanças rápidas da paisagem por outras como as agrícolas propiciam uma influência negativa no clima em decorrência das alterações antrópicas, causando mudanças em seus ciclos e afetando no futuro as próprias atividades humanas.

O Banco de dados criado no SPRING nos trouxe a viabilização de trabalhar com dados de diferentes resoluções espaciais e integrando-os com o objetivo de classificarmos os diversos modos de uso e cobertura da terra na área de estudo. Ele também pode dá suporte futuramente no desenvolvimento de outras pesquisas mais criteriosas para aperfeiçoarmos e detalharmos melhor os outros usos que deixaram de ser identificados no estado de São Paulo.

Os dados SRTM se mostraram oportunos para a elaboração do relevo e da declividade, principalmente com a facilidade na geração destes mapas pelo SPRING. Atualmente, os dados SRTM vêm sendo substituídos pelos do sensor ASTER/TERRA com resolução espacial de 30 metros favorecendo os estudos regionais e locais. 
As imagens do sensor MODIS reúnem consideráveis características para o mapeamento do uso e cobertura da terra, principalmente em se tratando de extensas áreas, como o estado de São Paulo. Reiteramos que as potencialidades deste sensor como, a alta resolução temporal, as características radiométricas, espaciais e a excelente acuidade geométrica de seus produtos como o EVI e NDVI são fundamentais no monitoramento de áreas para diversos tipos de uso e cobertura da terra entre outros estudos.

Os índices EVI e NDVI tiveram grande importância por ressaltarem as áreas com e sem vegetação, apesar de não termos identificados as fisionomias vegetais com seus percentuais de decréscimo ou acréscimo. Em outros trabalhos seria valida a análise com diferentes períodos quinzenais do MODIS ao longo do ano para a separação das fases de plantio das culturas. E assim possibilitar a estimação de safras como da cana-de-açúcar que apresenta $60 \%$ de toda produção localizada no estado de São Paulo (UNICA, 2005).

O EVI e NDVI confirmaram sua aplicabilidade como instrumental no monitoramento da cobertura verde no estado de São Paulo possibilitando uma significativa redução da demanda de tempo, recurso humano e material. Além de subsidiarem no apoio quanto à identificação de amostras de classes temáticas para o treinamento e na edição matricial pós-classificação das imagens-fração.

O Modelo linear de mistura espectral possibilitou uma melhor delimitação dos diferentes usos e coberturas da terra nas imagens-fração obtidas do sensor MODIS. Tal técnica aplicada nas três imagens-fração nos permitiu uma classificação concisa com a realidade terrestre. Sugerimos para futuros trabalhos de pesquisa a utilização das imagensfração solo ou sombra na determinação de fisionomias vegetais, método empregado no Projeto PRODES.

As imagens-fração foram contribuições inegáveis neste mapeamento, as quais tiveram bom aproveitamento e apresentaram uma resposta confiável para a classificação das modalidades de uso e cobertura da terra. Principalmente tendo como base os mapeamentos históricos de KELLER (1969), ANDERSON (1971) e et al.,(1979), JENSEN (1983) e TROPPMAIR (1983) que propiciaram o rápido reconhecimento das classes identificadas durante a fase de treinamento e edição matricial.

A segmentação das imagens-fração foi sem dúvida um processo demorado, mas recompensador pela extração de regiões. Imaginamos o tempo gasto que teríamos para a digitalização, correção e ajuste de linhas, gerações de mapas temáticos sem tal técnica. E ainda mediante a utilização do classificador por crescimento de regiões que nos apresentou um melhor potencial na identificação das formas de uso e cobertura da terra. 
É importante salientar que a utilização de imagens de média (CBERS) e alta resolução (presentes no Google EARTH) em contrapartida com os dados do MODIS nos possibilitaram um levantamento bastante eficaz e conclusivo quando comparamos com outras pesquisas desenvolvidas pelo extenuante e oneroso trabalho de campo em extensas regiões. Mas, tal vantagem aqui apresentada não visa substituir a vistoria in loco, a mesma tem o objetivo de fornecer subsídios para aperfeiçoar e tornar mais eficiente a vistoria de campo direcionando as áreas a serem vistoriadas na escala regional ou local.

O procedimento adotado com as imagens CBERS e Google EARTH nos deu embasamento para identificar corretamente as classes propostas, pois diferentes alvos podem apresentar respostas espectrais semelhantes. Assim, pudemos classificar os principais modos de uso e cobertura da terra, minimizando os erros de omissão e inclusão. É claro que ao compararmos algumas dúvidas com as imagens citadas tivemos o maior cuidado com a respectiva correspondência por pontos de controle via tela e utilizando os parâmetros de localização dos municípios.

O grande volume de dados processados e armazenados na presente pesquisa, sendo apresentados na forma de banco de dados, mapas entre outros podem ser disponibilizados futuramente para ás comunidade científica e acadêmica por um portal na internet. A WebGIS proporcionará as comunidades uma visualização interativa de toda a coleção de mapas apresentando os aspectos geográficos e as modalidades de uso e cobertura da terra do estado de São Paulo.

Finalizando, gostaríamos de ressaltar que as bases teórico-metodológicas juntamente com as inovações tecnológicas advindas das ciências como, a Geografia, da Agronomia, da Cartografia e do Geoprocessamento nos possibilitaram o conhecimento necessário e cabível para o desenvolvimento deste trabalho de pesquisa. 


\section{REFERÊNCIAS BIBLIOGRÁFICAS}

AB'SÁBER, A. N. A Terra Paulista. Bol. Paulista Geografia, São Paulo, n. 23, p. 5-38, 1956.

AB'SÁBER, A. N. São Paulo: Ensaios Entreveros. São Paulo: Editora da Universidade de São Paulo/ Impressa Oficial do Estado de São Paulo, 2004 p. 518. (ISBN 85-314-0721-4)

AGENDA BRASIL. Crise da segurança pública expõe situação de carência de municípios. Por Luciano Martins Costa e Mônica Paula. 2006. Em:

http://www.folhadaregiao.com.br/noticia?55197.

AGUIAR, D. A.; ADAMI, M.; RUDORFF, B. F. T.; SANCHÉZ, G. A.; BARROS, M. A.; SUGAWARA, L. M.; SHIMABUKURO, Y. E.; MOREIRA, M. A. Mapeamento da colheita da cana-de-açúcar no estado de São Paulo - ano safra 2006/2007. São José dos Campos: INPE, 2007. 48 p. (INPE-14788-RPE/811).

AGUIAR, D. A. Monitoramento da área colhida de cana-de-açúcar por meio de imagens do sensor MODIS. 2007. 103 p. (INPE-14803-TDI/1246). Dissertação (Mestrado em Sensoriamento Remoto) - Instituto Nacional de Pesquisas Espaciais, São José dos Campos. 2007.

AGUIAR, D. A.; ADAMI, M.; RUDORFF, B. F. T.; SUGAWARA, L. M.; DE FREITAS, R. M. Avaliação da conversão do uso e ocupação do solo para cana-de-açúcar utilizando imagens de sensoriamento remoto. In: SIMPÓSIO BRASILEIRO DE SENSORIAMENTO REMOTO, 14., Natal, 2009. Anais... São Paulo: Imagem Multimídia. Seção de Comunicações TécnicoCientífica, 2009. CD-ROM.

ALENCAR, A. A. C.; VIEIRA, I. C. G.; NEPSTAD, D. C.; LEFEBVRE, P. Análise multitemporal do uso do solo e mudança da cobertura vegetal em antiga área agrícola da Amazônia Oriental. In: SIMPÓSIO BRASSILEIRO DE SENSORIAMENTO REMOTO, 8., Salvador, 1996. Anais... São Paulo: Imagem Multimídia. Seção de Comunicações TécnicoCientífica, 1996. 1 CD-ROM.

ALMEIDA, F. F. M. de Fundamentos geológicos do relevo paulista. Bol. do Instituto Geográfico e Geológico, São Paulo, n. 41 p. 169-263, 1964.

ALMEIDA, F. F. M. de et al. Mapa Geológico do Estado de São Paulo, 1:500.000. Nota Explicativa. São Paulo, IPT, Monografia 6, 126 p., 1981.

ALMEIDA, J. Significados sociais, limites e potencialidades da Agroecologia. In: FERREIRA, A.; BRANDENBURG, A. Para pensar outra agricultura. Curitiba, Ed. da UFPR, 1998. p.239-247. 1999.

A construção social de uma nova agricultura. Porto Alegre, Ed. da UFRGS,

A Agronomia entre a teoria e a ação. Revista da Educação Agrícola Superior, Brasília, ABEAS, vol. 18., n.2, p. 7-13, 2000. 
ALVES, D. S.; PEREIRA, J. L. G.; SOUSA, C. L.; SOARES, J. V.; MOREIRA, J. C.; ORTIZ, J.O.; SHIMABUKURO, Y. E.; YAMAGUCHI, F. Análise comparativa de técnicas de classificação de imagens do sensor Landsat/TM para caracterização de áreas desflorestadas. In: SIMPÓSIO BRASILEIRO DE SENSORIAMENTO REMOTO, 9., Santos, 1998. Anais... São Paulo: Imagem Multimídia. Seção de Comunicações Técnico-Científica, 1998. 1 CD-ROM.

AMBIENTE BRASIL. Ambientes (Natural - Vegetação Brasileira). Acesso em: 18 Jun. 2006. $<$ http://ambientes.ambientebrasil.com.br/natural.html>

ANDERSON, C. Zonas Produtoras de Café. São Paulo, Anderson, Clayton \& Co., S.A. 1967.

ANDERSON, J. R. Land use classification schemes used in selected recent geographic applications of remote sensing. Photogramm. Eng., 37 (4): 379-87, 1971.

ANDERSON, J. R., HARDY, E. E., ROACH, J. T., WITMER, R. E. Sistema de classificação do uso da terra e do revestimento do solo para utilização com dados de sensores remotos. Rio de Janeiro - IBGE, 1979.

ANDERSON, P. S. Fundamentos para fotointerpretação. Rio de Janeiro: Sociedade Brasileira de Cartografia, 1982. $136 \mathrm{p}$.

ANDERSON, L. O.; LATORRE, L. M.; SHIMABUKURO, Y. E.; ARAI, E.; JÚNIOR CARVALHO, O. A. de Sensor MODIS: Uma Abordagem Geral. São José dos Campos, INPE, 2003. 54 p. (INPE-10131-RPQ/752).

ANDRADE, M. C. Geografia, Ciência da Sociedade: uma introdução à análise do pensamento geográfico. São Paulo: Atlas, 1987.

ARCHELA, R. S. A cartografia no pensamento geográfico. Disponível em: < http://br.geocities.com/cartografiatematica/texto/pensamen.html > Acesso em: 15 set 2009.

ARONOFF, S. Geographic Information Systems: o management perspective. Ottawa:WDL, 1989. 294 p.

ASSAD, E. D.; SANO, E. E. Sistema de Informações Geográficas: aplicações na Agricultura. Brasília: EMBRAPA - CPAC, 1993. 274 p.

ASNER, G. P. Biophysical and biochemical sources of variability in canopy reflectance. Remote Sensing of Environment, v. 64, p. 234-253. 1998.

BAECHER, G. B.; SANGREY, D. A. Geotechnical engineering workbench. Geotechnical Engineering Congress. Geotechnical Special Publication, n. 27, ASCE, 1991, p. 10441056.

BÄHR, H. P. Sistemas de informação geográfica e cartografia: uma estreita relação. Fator Gis, Curitiba, Ano I, n. 2, p. 41, 1993. 
BARBOSA, C. C. F. Álgebra de Mapas e suas Aplicações em Sensoriamento Remoto e Geoprocessamento. 152 f. Dissertação (Mestrado em Sensoriamento Remoto) - INPE, São José dos Campos, 1997.

BARET, F.; GUYOT, G.; MAJOR, D. J. Crop biomass evaluation using radiometric measurements. Photogrammetria (PRS), v. 43, n. 5, p. 241-256. 1989.

BARKER, J. L.; HARDEN, M. K.; ANUTA, E. A.; SMID, J.; HOUGT, D. MODIS spectral sensivity study: requirements and characterization. Washington: NASA, Oct, 1992, $84 \mathrm{p.}$

BARROS, H. de. Os grandes sistemas de organização da economia agrícola. Lisboa: Sá da Costa , 1975.

BERTIN, J. Les constantes da La Cartographie. International Yearbook of Cartography, v. $11,1971$.

Théorie de La communication et théorie de la graphique. Mélanges Charles Morazé, Privat, Toulouse, 1978.

. Ver ou ler. Seleção de Textos, n.18, p. 41-48, 1988.

BERTRAND, G. Paisagem e Geografia Física Global: Esboço Metodológico. Cadernos de Ciência da Terra. São Paulo: IGO/USP, n.13, p. 1-27, 1971.

BINS, L. S.; ERTHAL, G. J.; FONSECA, L. M. G. Um método de classificação não supervisionado por regiões. In: SIMPÓSIO BRASILEIRO DE COMPUTAÇÃO GRÁFICA E PROCESSAMENTO DE IMAGENS, 5., 1992, Águas de Lindóia. Anais... São José dos Campos: INPE, 1992, v. 2, p. 65-68.

BINS, L. S.; FONSECA, L. M. G.; ERTHAL, G. J.; II, F. Satellite Image Segmentation: a region growing approach. In: SIMPÓSIO BRASILEIRO DE SENSORIAMENTO REMOTO, 8., 1996, Salvador. Anais... São Paulo: Imagem Multimídia. Seção de Comunicações TécnicosCientíficas. 1996. 1 CD-ROM.

BRASIL. Ministério do Interior. SEMA - RQMA: Relatório da Qualidade do Meio Ambiente: Sinopse. Brasília: SEMA, 1984.

BURLEY, T. M. Land Use pr Land Utilization?. The Professional Geographer, v. 3, n. 6, p. $18-20,1961$.

BURROUGH, P. A. ; MCDONNEL, R. A. Principles of Geographical Information Systems. Oxford: Claredon Press, New York: Oxford University Press, 1998. 193 p.

BRANDALIZE, A. A. Cartografia: Modernizando Conceitos. Curitiba. Fator GIS, Curitiba, Ano I, n. 1, p. 26, 1993.

CÂMARA, G. Modelos, linguagens e arquiteturas para banco de dados geográficos. São José dos Campos. 265 f. Tese (Doutorado em Computação Aplicada) - Instituto Nacional de Pesquisas Espaciais, 1995. 
CÂMARA, G.; MEDEIROS, J. S. Geoprocessamento para Projetos Ambientais. São José dos Campos. Instituto Nacional de Pesquisas Espaciais - INPE, 1996a, 36p. [CD-ROM].

CÂMARA, G.; CASANOVA, M. A.; HEMERLY, A. S.; MAGALHÃES, G. C.; MEDEIROS, C. M. B. Anatomia de Sistemas de Informação Geográfica. Campinas: Instituto de Computação, UNICAMP, 1996b. 197 p.

CANASAT. Mapeamento de cana via satélites de observação da Terra. 2009. Disponível em: <http://www.dsr.inpe.br/mapdsr/>. Acesso em: 07 abr. 2009.

CARVALHO, A. P. F. DE; GUIMARÃES, R. F.; CARVALHO JR., O. A. DE; BUSTAMANTE, M. M. DA C. Metodologia para Análise de Mistura Espectral em Imagens TM-Landsat. In: SIMPÓSIO BRASILEIRO DE SENSORIAMENTO REMOTO, 10., 2001, Foz do Iguaçu. Anais... São Paulo: Imagem Multimídia. Seção de Comunicações Técnicas - Científicas, 2001, p. 1531-1538. 1 CD-ROM.

CASSETI, W. Ambiente e apropriação do relevo. São Paulo, Contexto, 1991.

CAVALLI, A. C., GUILLAUMON, J. R. \& SERRA, R. Cobertura vegetal natural (Florestas) do estado de São Paulo. 1973.

CBERS, 2008. Introdução do Satélite CBERS. Divisão de Geração de Imagem. Instituto Nacional de Pesquisas Espaciais - INPE. Disponivel em: < http://www.cbers.inpe.br/ > Acesso em: 03 abr 2008.

CENTRO DE PESQUISA METEOROLÓGICAS E CLIMÁTICAS APLICADAS À AGRICULTURA (CEPAGRI). Campinas, 2006. Disponível em: $<$ www.cepagri.unicamp.br/outras-informacoes/clima-dos-municipios-paulistas.html> Acesso em: 27 Mar 2008.

CESAR, C. L. G.; CARANDINA, L.; ALVES, M. C. G. P.; BARROS, M. B. de A.; GOLDBAUM, M. Saúde e condição de vida em São Paulo. 1. ed. São Paulo: FSP/USP, 2005. v. 1. 212 p.

CHEN, C. S.; TARDIN, A. T.; BATISTA, G. T. Índices de vegetação e suas aplicações na agricultura. Instituto Nacional de Pesquisas Espaciais - INPE, São José dos Campos, 1986. 24 p. (INPE-3912-MD/030).

CHIARINI, J. V. e DONZELI, P. L. Levantamento por Fotointerpretação das Classes de Capacidade de Uso das Terras do Estado de São Paulo. Boletim Técnico (3). Campinas, IAC. 1973

CHIARINI, J. V.; BORGONOVI, M.; AMARAL, A. Z. DO; COELHO, A. G. DE S.; OLIVEIRA, D. DE A. Uso do Solo no Estado de São Paulo, em 1962. In:CONGRESSO BRASILEIRO DE CIÊNCIA DO SOLO, 10., Brasília, Anais... Brasília, v. 37, n. 8, p. 70-71, 1978,

CHOLLEY, A. Observação sobre alguns pontos de vista geográficos. Primeira Parte. Boletim de Geografia. Rio de Janeiro: IBGE, n.179, 1964.

CHRISTOFOLETTI, A. Análise de sistemas em geografia. São Paulo: HUCITEC, 1981. 
CHUVIECO, E. Fundamentos de teledetección espacial. Madrid: Ediciones Rialp, 1996, $568 \mathrm{p}$.

CLAWSON, M. \& STEWART, C. L. Land Use Information: a critical survey of U.S. statistics including possibilities for greater uniformity. Baltimore: Johns Hopkins Press, 1965. 402 p.

COMISSÃO DO IV CENTENÁRIO da cidade de São Paulo. São Paulo Antigo Plantas da Cidade. Ed. Melhoramentos. São Paulo, 1954.

COMPANHIA NACIONAL DE ABASTECIMENTO - CONAB. Ministério da Agricultura, Pecuária e Abastecimento. Perfil do setor de açúcar e álcool no Brasil. Brasília: CONAB, 2008.

COMPANHIA NACIONAL DE ABASTECIMENTO - CONAB. Ministério da Agricultura, Pecuária e Abastecimento. Zoneamento Agroambiental para o setor sucroalcooleiro do estado de São Paulo. Em: < www.ambiente.sp.gov.br/zoneamentoagroambientalcana.pdf > Acesso: 03 Maio 2009 as 16hs.

COLWELL, J. E. Vegetation canopy reflectance. Remote Sensing of Environment, New York, v. 3, n. 3, p. 175-183, 1974.

CONTI, J. B. A Geografia Física e as relações sociedade/natureza no mundo tropical. São Paulo: Humanitas Publicações - FFLCH/USP, 1997.

CORRÊA, R. L. Espaço, Um conceito chave da Geografia. In: CASTRO, I. E. DE, GOMES, P. C. DA C.; CORREAA, R. L. Geografia: conceitos e temas. 5. ed. Rio de Janeiro: Bertrand Brasil, 2003.

COSTA, D. A. de A. Uso e Ocupação da Terra e as Regiões Hidrográficas Brasileiras. Nota Técnica para o subsidio do Plano Nacional de Recursos Hídricos do Brasil. 2005, 1-9 p. Disponivel em :<http://br.geocities.com/danazevedo/GEOGRAFIA.html 11h23>. Acesso em: 30 jun. 2009.

COWEN, D. J. GIS versus CAD versus DBMS: What are the differences? Photog. Eng. and Rem. Sen., v. 54, p.1551-4, 1988.

COUTINHO, A. C.; MIRANDA, E. E. DE; MIRANDA, J. R. Mapeamento da superfície terrestre através da utilização do método de segmentação por crescimento de regiões e classificação supervisionada de imagens de satélite. In: SIMPÓSIO BRASILEIRO DE SENSORIAMENTO REMOTO, 9., 1998, Santos. Anais... São Paulo: Imagem Multimídia. Seção de Comunicações Técnicos-Científicas, 1998. 1 CD-ROM.

CRÓSTA, A. P. Processamento digital de imagens de sensoriamento remoto. Campinas: IG/UNICAMP, 1992. 170p.

CURRAN, P. J.; WARDLEY, N. W. Radiometric leaf area index. International Journal of Remote Sensing, London, v. 9, n. 2, p. 259-274, 1988.

CURRAN, P. J., FOODY, G. M., KONDRATYEV, K. Ya., KOZODEROV, V. V., FEDCHENKO, P. P. Remote Sensing of soils and vegetation in the USSR. London: Taylor \& Francis, 1990. 
D’AGOSTINI, L. R. ; SCHLINDWEIN, S. L. Dialética da avaliação do uso e manejo das terras: da classificação interpretativa a um indicador de sustentabilidade. Florianópolis, Ed. UFSC, 1998.

DEÁK, C. Rent theory and the price of urban land/ Spatial organization in a capitalist economy PhD Thesis, Cambridge, Cap 4: "Location and space" e 7: "Anatomy of the transformation of land use" (1985).

DE BIASE, M. A Carta Clinográfica. Os Métodos de Representação e sua Confecção. Revista do Departamento de Geografia. São Paulo: FFLCH/USP, n. 6, 1992.

DE MARTONNE, E. Evolução da Geografia. In: Panorama da Geografia. Tradução e organização Vitorino Magalhães Godinho. V.I, Lisboa: Cosmos, 1953. P. 1-22.

DIGITAL CARTOGRAPHIC DATA STANDARDS TASK FORCE (DCDSTF). The proposed standard for digital cartographic data. The American Cartographer, v. 15, n. 1, p. 9-140, 1988.

DEFFONTAINES, P. Regiões e paisagens do Estado de São Paulo. Geografia, S. Paulo, 1(20):39-53,1935

DEFFONTAINES, J. P. L' agronome: discipline et interdiscipline. In: JOLLIVET, M. Sciences de la nature, sciences de la société: les passeurs de frontiéres. Paris, CNRS Editions, 1992, p. 113-128.

DEPARTAMENTO DE ÁGUAS E ENERGIA ELÉTRICA. Plano estadual de recursos hídricos: primeiro plano do estado - síntese. São Paulo: DAEE, 1990. 97 p.

DERRING, D. W.; ROUSE, J. W.; HAAS, R. H.; SCHELL, J. A. Measuring forage production of grazing units from Landsat MSS data. In: INTERNATIONAL SYMPOSIUM ON REMOTE SENSING OF ENVIRONMENT, 10., Ann Arbor, 1975. Proceedings. University of Michigan, 1975. v. 2, p. 1169-1178.

DIEHL, R. Agricultura Geral. Clássica Editora, Lisboa, 1984.

DLR - German Remote Sensing Data Center. SRTM Prices. Disponivel em: $<$ http://www.dlr.de/SRTM/>. Acesso em: 15 maio 2008.

DUARTE, V.; SHIMABUKURO, Y. E.; SANTOS, J. R.; MELLO, E. M. K.; MOREIRA, J. C.; MOREIRA, M. A.; SOUZA, R. C. M.; SHIMABUKURO, R. M. K.; FREITAS, U. M.

Metodologia para criação do Prodes digital e do banco de dados digitais da Amazônia - BADDAM ${ }^{1}$. São José dos Campos: INPE, 1999, 33p.

EDGERTON, C. W. Sugarcane and its diseases. Baton Rouge, L.A.: Lousiana State University, 1958. 301p.

EGBERT, D. D. A practical method for correcting bidirectional reflectance variation. In: MACHINE PROCESSING REMOTELY SENSED DATA SYMPOSIUM. Proceedings... 1977. p.178-189. 
EMPRESA PAULISTA DE PLANEJAMENTO METROPOLITANO S.A. (EMPLASA). São Paulo (Estado). Metrópoles em dados. Disponível em: <http://www.emplasa.sp.gov.br>. Acesso em: 15 nov 2000.

ERTHAL, G. J.; FONSECA, L. M. G.; BINS, L. S.; VELASCO, F. R. D.; MONTEIRO, A. M. V. Um sistema de segmentação e classificação de imagens de satélite. In: SIMPÓSIO BRASILEIRO DE COMPUTAÇÃO GRÁFICA E PROCESSAMENTO DE IMAGENS, 4., 1991, São Paulo. Anais... São Paulo: EDUSP, 1991, v. 1, p. 237-240.

ERTHAL, G. J. Processamento digital de imagens: notas de aula dadas no Instituto Nacional de Pesquisas Espaciais. São José dos Campos, 3., 1998. 127 p.

ESTEIO. Disponível em :<www.esteio.com.br/newsletters/paginas/006/coordenadas.htm $>$ Acesso em: 27 jun 2005.

EVA, H. D. et al. A Vegetation Map of America. GEOBRASIL. O Estado do meio ambiente no Brasil. IBAMA. 2002, 48 p.

FAO: a framework for land evaluation. Roma: FAO; Wageningen: ILRL, 1976. 72 p. (Soil Bulletin, n. 29).

FELDMAN, W. As Propostas de Walter Feldman para a Saúde. Sala de Imprensa. 2006. Disponível em: <www.walterfeldman.com.br>. Acesso em: 25 out 2009.

FELGUEIRAS, C. A. A Tecnologia SPRING, breve histórico, status atual e evolução. In: SIMPÓSIO DE GEOTECNOLOGIAS NO PANTANAL, 1., (GEOPANTANAL), 2006, Campo Grande. Anais. Embrapa Informática Agropecuária - INPE, 2006, p. 811-824. 1CD-ROM.

FERREIRA, C. C. ; SIMÕES, N. N. A Evolução do Pensamento Geográfico. Lisboa: Gradiva, 1990.

FLEMING, D. Vegetation Index Definitions. In: CRESS Project, UMCP Geography, June 2000. Erdas Imagine 8.4 property of the Leika Geosystems. Materials Copyright to the University of Maryland, Department of Geography, CRESS Project, 2001.

FLORENZANO, T. G. Imagens de satélite para estudos ambientais. São Paulo: Editora Oficina de Textos, 2002, $97 \mathrm{p}$.

FORMAGGIO, A. R. Comportamento espectral de alvos - solos. Material do Curso de Comportamento Espectral de Alvos. XIII Curso Internacional de Sensoriamento Remoto INPE - DSM. São José dos Campos - SP. 1999, 21 p.

FUNDAÇÃO SISTEMA ESTADUAL DE ANÁLISE DE DADOS (SEADE). São Paulo (Estado). Características gerais do processo de industrialização paulista. São Paulo: SEADE, 1988.

FUNDAÇÃO SISTEMA ESTADUAL DE ANÁLISE DE DADOS (SEADE). São Paulo (Estado). Regiões Administrativas e metropolitanas do Estado de São Paulo. Disponível em: <http://www.seade.gov.br>. Acesso em: 19 nov 2000. 
GATES, D. M.; KEEGAN, H. J.; SCHLETER, J. C.; WEIDNER, V. R. Spectral properties of plants. Applied Optics, Easton, v.4, n. 1, p. 11-20, 1965.

GERAQUE, E. Solução Multissetorial. Ambiente. Ciência. Boletim. Pesquisa FAPESP, São Paulo, fev. 2006. Disponível em: < http://www.agencia.fapesp.br/boletim>. Acesso em: 10 abr 1999.

GOEL, N. S. Models of vegetation canopy reflectance and their use in estimation of biophysical parameters from reflectance data. Remote Sensing Reviews, New York, v. 4, n. 1, p. 1-212, 1988.

GOMES, H. A Produção do espaço geográfico no capitalismo. São Paulo:Contexto, 1990.

Reflexões sobre teoria e crítica em Geografia. Goiânia: CEGRAF/UFG, 1991.

GONÇALVES, C. V. P. Os (des)caminhos do meio ambiente. Contexto. São Paulo 1989.

GRIGG, D. B. A lógica dos sistemas regionais. Annals of the Association of American Geographers, 55, 465-491, 1965.

GUIMARÃES, F. M. S. O Relevo do Brasil. Rio de Janeiro. Boletim Geográfico (CNG), ano I, n. 4, jul., p. 63-72, 1943

HANSEN, K. L. GIS vs CAD vs DBMS em mapeamento digital: Exemplos em Engenharia Ambiental. In: CONGRESSO BRASILEIRO DE CARTOGRAFIA, 1989, Brasília - DF. Anais... Brasília: SBC, 1989.

HARTSHORNE, R. El concepto de geografia como ciência del espacio: de Kant y Humboldt a Hettner. Documentd d' Anàlisi Geogràfica, n.18, 1991. p. 31-54

HAYASHI, S. N.; ALENCAR, A. Métodos comparativos para a detecção de extração seletiva de madeira no oeste Paraense utilizando modelo linear de mistura espectral de pixel. In: SIMPÓSIO BRASILEIRO DE SENSORIAMENTO REMOTO, 11., 2003, Belo Horizonte. Anais... São Paulo: Imagem Multimídia. Seção de Comunicações Técnico-Científicas, 2003, p. 1311-1313. 1 CD-ROM.

HENIN, S. (1967) Les acquisitions techniques en pro-duction végétale et leurs applications. In: Économie Rurale. v. 74, n. 1, 1967. p. 31-44

HOFFER, R. M.; JOHANNSEN, C. J. Ecological potentials in spectral signature analysis. In: Johnson, P. L. Remote Sensing in Ecology. Athens: Ed. University of Georgia Press, 1969. p. 1-16.

HUETE, A. R., JUSTICE, C., LIU, H. Development of vegetation and soil indices for MODISEOS. Remote Sensing of Environment, New York, v.49, p. 224-234, 1994. 
HUETE, A. R. LIU, H. Q., BATCHILY, K., VAN. LEEUWEN, W. A comparison of vegetation indices over a global set of TM images for EOS-MODIS. Remote Sensing of Environment, New York, v.59, p. 440-451, 1997.

HUETE, A. R.; JUSTICE, C. E VAN LEEUWEN, W. MODIS Vegetation Index (MOD13): Algorithm Theoretical Bases Document. Version 3. [on line]. Disponível em: < http://tbrsarizona.Edu/projects/modis/ > Acesso em: 22 abril de 1999.

HUETE, A.; JUSTICE, C.; VAN LEEUWEN, W. MODIS Vegetation index (MOD13) algorithm theoretical basis document. versão 3, p. 1-142, 1999. Disponível em: <modisland.gsfs.nasa.gov/pdfs/atbd_mod13.pdf>. Acesso em: 7 nov. 2002.

INSTITUTO BRASILEIRO DE GEOGRÁFIA E ESTATISTICA (IBGE).. Atlas Nacional do Brasil. Rio de Janeiro. 2000.

Censo Demográfico 2000: Resultados Preliminares, Rio de Janeiro. 2000.

Cidades. Disponível em: <http://www.ibge.gov.br/cidadesat/topwindow.htm?1> Acesso em: 25 mar. 2000.

Cidades. Disponível em: <http://www.ibge.gov.br/cidadesat/topwindow.htm?1> Acesso em: 04 dez. 2005.

2010.

Cidades. <http://www.ibge.gov.br/cidadesat/topwindow.htm?1> Acesso: 10 Mai.

INSTITUTO DE PESQUISAS TECNOLÓGICAS DO ESTADO DE SÃO PAULO (IPT). Mapa Geológico do Estado de São Paulo, Pró-Minério, 1981.

INSTITUTO DE PESQUISAS TECNOLÓGICAS DO ESTADO DE SÃO PAULO (IPT). Carta Geotécnica do Estado de São Paulo. São Paulo, 1994.

INSTITUTO FLORESTAL DO ESTADO DE SÃO PAULO (IF). Inventário Florestal do Estado de São Paulo. 1993.

INSTITUTO FLORESTAL DO ESTADO DE SÃO PAULO (IF) Disponível em: <http://www.iflorestsp.br > Acesso em: 29 out 2005.

INSTITUTO GEOGRÁFICO E CARTOGRÁFICO (IGC). Rede hidrográfica do estado de São Paulo. Escala 1:1000.000, 1985.

INSTITUTO NACIONAL DE ESTUDOS E PESQUISAS (INEP). Situação do Ensino no Estado de São Paulo. Disponível em: < http://www.inep.gov.br/>. Acesso em: 25 jan 2009.

INSTITUTO NACIONAL DE PESQUISAS ESPACIAIS - INPE. Departamento de Processamento de Imagens - DPI. SPRING: SPRING Básico - Tutorial SPRING. Versão 3.3 Disponível em: <http://www.dpi.inpe.br/spring > Acesso em: 10 jul 1999.

Departamento de Processamento de Imagens - DPI. SPRING: SPRING Usuário. Disponível em: <http://www.dpi.inpe.br/spring> Acesso em: 19 abril 2008. 
Mar 2000.

. Departamento de Processamento de Imagens - DPI. COMUNICAÇÃO VERBAL.

INSTITUTO SÓCIO AMBIENTAL (ISA). FHC e a Legislação Protetora da Mata Atlântica: avanços ou retrocessos? São Paulo: ISA, 18 de setembro de 1995.

ISNARD, H. Espaço Geográfico, Coimbra: Almedina, 1982.

JACKSON, R. D.; REGINATO, R. J.: PRINTER, P. J.; IDSO, S. B. Plant canopy information extraction from composite scene reflectance of row crops. Applied Optics, Easton, v. $18 \mathrm{n}$. 22, p. 3775-3782, 1979.

JACKSON, R. D. Spectral indices in n-Space. Remote Sensing of Environment, v. 13, 1983. p. 409-421.

JACKSON, R. D.; HUETE, A. R. Interpreting vegetation indices. Preventive veterinary Medicine, v. 11, n. 2, 1991. p. 185-200.

JENSEN, J. R. Urban/suburban land use analysis. In: Manual of remote sensing v. 2. 2. ed. Falls Church, V. A.: American Society of Photogrammetry, 1983. p. 1571-1666.

Introductory Digital Image Processing: a remote sensing perspectiva. Upper Saddle River, NJ: Prentice Hall, 1996. 316 p.

Sensoriamento remoto do ambiente: uma perspectiva em recursos terrestres. Tradução da 2 ed. por (pesquisadores do INPE): José Carlos N. Epiphanio (coordenador); Antonio R. Formaggio; Athos R. Santos; Bernardo F. T. Rudorff; Cláudia M. Almeida; Lênio S. Galvão. São José dos Campos: Parêntese. 2009. 672 p.

JOLY, F. A cartografia. Campinas, SP: Papirus - 1990.

JUSTICE, C. O.;VERMOTE, E.;TOWNSHEND, J. R. G.; DEFRIES, R.; ROY, P. D.; HALL, D. K.;SALOMONSON, V.;PRIVETTE, J. L.;RIGGS, G.;STRAHLER, A.;LUCHT, W.;MYNENI, B.;KNYAZIKHIN, Y.;RUNNING, W.S.;NEMANI, R. R.;WAN, Z.;HUETE, A. R.;LEEUWEN, W. V.;WOLFE, R. E.; GIGLIO, L.;MULLER, J. P.;LEWIS, P.; BARNSLEY, M. The Moderate Resolution Imaging Spectroradiometer (MODIS): land remote sensing for global change research. IEEE Transactions on Geoscience and Remote Sensing, v. 36, n. 4, p. 12281247, July, 1998.

JUSTICE, C. O.; GIGLIO, B.; KORONTZI, S.; OWENS, J.; MORISETTE, J. T.; ROY, D. P.; DESCLOITRES, J.; ALLEAUME, S.; PETITCOLIN, F.; KAUFMAN, Y. The MODIS fire products. Remote Sensing of Environment, v. 83, n. 1-2:P. 244-26, 2002.

JUPP, D. L. B.; WALKER, J.; PERRIFGE, L. K. Interpretation of vegetation structure in Landsat MSS imagery a case of study in disturbed semi-arid Eucalypt woodland. Part 2. Model-based analysis. Journal Environmental Management, New York, v. 23, p. 35-57, 1986.

KAUFMAN, Y. J.; TANRÉ, D. Atmospherically resistant vegetation index (ARVI) for EOSMODIS. IEEE Transactions on Geosciences and Remote Sensing, v. 30, n. 2, p. 261270, 1992. 
KAUTH, R. J. ; THOMAS, G. S. The tasseled Cap: a graphic description of the spectraltemporal development of agricultural crops as seen by Landsat. Symposium on the Machine Processing of Remotely Sensed Data, London, Proceedings. 1976.

KAZMIERCZAK, M. L. Proposta Metodológica para Geração de Imagens NDVI derivadas do AVHRR/NOAA-14 na FUNCEME [CD-ROM]. In: Simpósio Brasileiro de Sensoriamento Remoto, 8., Salvador, 1996. Anais. São Paulo: Imagem Multimídia. Seção de Comunicações Técnicos-Científicas, 1996. 1 CD-ROM.

KELLER, E. C. DE S. Projeto do Mapeamento da Utilização da Terra. Aerogeografia, n. 3 Instituto de Geografia - USP, 1969.

KIMES, D. S.; KIRCHNER, J. A. Diurnal variations of vegetation canopy structure. International Journal of Remote Sensing, London, v.4, n. 2, p. 257-271, 1983.

KING, M.; KAUFMAN, Y; MENZEL, W. AND TANRÉ, D. Remote Sensing of cloud, aerosol and water vapor properties from the Moderate Resolution Imaging Spectrometer (MODIS). IEEE Transactions Geoscience and Remote Sensing, v. 30, n. 1, Jan, 1992.

KRONKA, F. J. N., NALON, M. A., MATSUKUMA, C. K., KANASHIRO, M. M., YWANE, M. S. S.,. LIMA, L. M. P. R, GUILLAUMON, J. R., BARRADAS, A. M. F., PAVÃO, M., MANETTI, L. A., BORGO, S. C. Monitoramento da vegetação natural e do reflorestamento no Estado de São Paulo. [CD-ROM]. In: Simpósio Brasileiro de Sensoriamento Remoto, 12., Goiânia, 2005. Anais. São Paulo: Imagem Multimídia. Seção de Comunicações Técnicos-Científicas, 2005. P. 1569-1576.

KONDRACKI, J. \& OSTROWSKI, J. "Map of the sinantropization of the environment in Poland". Examples of Environmental Maps, Madrid, 1980.

KORTH, H. F. ; SILBERSCHATZ, A. Sistema de banco de dados. São Paulo, McGraw Hill, 1994. 205 p.

KUMAR, R. Radiation from plants, reflection and emission : a review. Lafayette, Purdue Research Foundation, 1972. 88 p. (Research Project n. 5543),

LACOSTE, Y. Os objetos geográficos. In: Cartografia Temática. Seleção de Textos.São Paulo: AGB. 1988.

LANDCOVER, 2008. Landcover-Web. Disponível em: <http://translate.google.com.br/ >. Acesso em: 09 set 2008.

LEPSCH, I. F., BELLINAZZI JR., R., BERTOLINI, D., ESPÍNDOLA, C. R. Manual para Levantamento Utilitário no Meio Físico e Classificação de Terras para o Sistema de Capacidade de Uso. 4aㅗ Aproximação. Campinas: Sociedade Brasileira de Ciências do Solo, 1983.

LEPSCH, I. F. Formação e conservação dos solos. São Paulo: Oficina de Textos, 2002, $178 \mathrm{p}$.

LIBAULT, A. As Tendências atuais da Cartografia. Boletim Paulista de Geografia. São Paulo: AGB/SP, no 44, 1967. 
LIEBIG, J. Chemistry and its application to agriculture and physiology. Taylor and Walton, London, 1840.

LILLESAND, T. M.; KIEFER, R. M. Remote Sensing and image interpretation. 2. ed. New York: John Wiley \& Sons, Inc., 1987, $721 \mathrm{p}$.

LILLESAND, T. M.; KIEFER, R. M. Remote Sensing and image interpretation. New York, N. Y. : Academic Press, 1994, 392 p.

LIU, H.Q.; HUETE, A.R. A feedback based modification of the NDVI to minimize canopy background and atmospheric noise. IEEE Transactions on Geoscience and Remote Sensing, New York, v.33 p. 457-465, 1995.

LIU, W. T. H. Aplicações de Sensoriamento Remoto. Campo Grande: Ed. YNIDERP, 2006. 908 p.

MANTERO, J. M. Cartografia general. Barcelona, Ediciones Omega, 1953. 435 p.

MANTOVANI, J. E. Comportamento espectral da água: faixas de maior sensibilidade do fitoplâncton na presença de matéria orgânica dissolvida e de matéria inorgânica particulada. São José dos Campos. 98 p. Dissertação (Mestrado em Sensoriamento Remoto) Instituto Nacional de Pesquisas Espaciais - INPE, 1993.

MAPLANBRASIL. AEROLEVANTAMENTOS

<http://www.maplanbrasil.com.br/frames/faq frame.htm> Acesso: 22 abr 2008.

MARCHETTI, D. A. B. ; GARCIA, G. J. Princípios de Fotogrametria e Fotointerpretação. São Paulo: Nobel, 1986. 257 p.

MARSCHNER, F. J. Major Land Uses in the United States. Reston, VA: U.S. Dept. of Agriculture, Agr. Research Service, 1950 Map.

MARINHA DO BRASIL, Diretoria de Hidrografia e Navegação. Cartografia: estudos e guia para a Construção e uso de mapas e cartas. 131 p. (Tradition of Special Publication no. 205 - Cartography - A review and guide for the construction and use of map and chart Revised edition 1943 by C. H. Deetz of U. S. Coast and Geodetic Survey). 1949.

MARTINELLI, M. A Cartografia da geografia: um processo de comunicação com linguagem gráfica visual. In: ENCONTRO NACIONAL DE GEOGRÁFOS, 6, Campo Grande, 1986. Anais....Campo Grande, 1986.

Curso de Cartografia Temática. São Paulo: Contexto, 1991.

As representações gráficas da geografia: os mapas temáticos. Tese (Livre Docência) - FFLCH, Universidade de São Paulo, São Paulo, 1999. 258 p.

Mapas da geografia e cartografia temática. 4. ed., São Paulo: Contexto, 2007.

O Atlas do Estado de São Paulo: uma reflexão metodológica. Confins [Online], 7, 2009. Disponível em: <http://confins.revues.org/index6166.html>. Acesso em: 14 abr 2010. 
Clima do Estado de São Paulo. Confins [Online], 8, 2010. Disponível em:

$<$ http://confins.revues.org/index6166.html >. Acesso em: 24 jan 2010.

O Relevo do Estado de São Paulo. Confins [Online], 7, 2009. Disponível em: < http://confins.revues.org/index6166.html $>$. Acesso em: 03 mar 2010.

MATHER, P. M. Computer of remotely-sensed images: an introduction. Chichester: Jonh Wiley \& Sons, 1987. 352 p.

MCMURTREY, J. E., CHAPPELLE, E. W., DAUGHTRY, C. S. T., KIM, M.S. Fluorescence and reflectance of crop residue and soil. Journal of Soil and Water Conservation, Ankeny, IO, v.48, n.3 p. 207-213, 1993.

MEIO AMBIENTE. GOVERNO DO ESTADO DE SÃO PAULO - SP. Áreas de Proteção Ambiental do Estado de São Paulo. Disponível em: $<$ http://www.ambiente.sp.gov.br/apas/apa.htm>. Acesso em: 20 maio 2004.

MELGAÇO, L. DE M.; FILHO, C. R. DE S.; STEINMAYER, M. Comparação entre modelos digitais elevação gerados por sensores ópticos e por radar. In: SIMPÓSIO BRASILEIRO DE SENSORIAMENTO REMOTO, 12., Goiânia, 2005. Anais... São Paulo: Imagem Multimídia. Seção de Comunicações Técnico-Científicas, 2005, p. 1215-1220. 1 CD-ROM.

MELLO, E. M. K.; MOREIRA, J. C.; SANTOS, J. R.; SHIMABUKURO, Y. E.; DUARTE, V.; SOUZA, I. M.; BARBOSA, C. C.; SOUZA, R. C. M.; PAIVA, J. A. C. Técnicas de modelo de mistura espectral, segmentação e classificação de imagens TM-Landsat para 0 mapeamento do desflorestamento da Amazônia. In: SIMPÓSIO BRASILEIRO DE SENSORIAMENTO REMOTO, 11., 2003, Belo Horizonte. Anais... São Paulo: Imagem Multimídia. Seção de Comunicações Técnico-Científicas, 2003. p. 2807-2814. 1 CD-ROM.

MENDOÇA, F. A. Geografia e Meio Ambiente. São Paulo: Contexto, 2001.

MENEGETTE, A. A. C. Cartographic accuracy and information content of space imagery for digital map compilation and map revision. 1987. $464 \mathrm{f}$. Tese - University College London, London, 1987.

MINISTÉRIO DOS TRANSPORTES. Ferrovias Bandeirantes - FERROBAN. Disponível em <http://www.brasilescola.com/geografia/ferrovias.htm>. Acesso: 13 ago. 2003.

Informações sobre Barragens - UEH. Disponível em

<http://www.transportes.gov.br>. Acesso: 10 jan. 2006.

Instituto de Pesquisas Hidroviárias - INPH. Disponível em <

http://www.brasilescola.com/geografia/hidrovias.htm>. Acesso: 20 dez. 2008.

MONBEIG, P. A Divisão Regional do Estado de São Paulo. An. da Assoc. dos Geógrafos do Brasil, São Paulo. n. 1 (1945/1946). p. 19-30, 1949.

MONTEIRO, C.A.F. A dinâmica climática e as chuvas do estado de São Paulo: estudo geográfico sob forma de atlas. São Paulo: IGEOG, 1973. 
MONTEIRO, C. A. F. O clima e a organização do espaço no Estado de São Paulo: Problemas e Perspectivas, IG-USP \& Monteiro, C. A. F. Variações espaciais de temperatura: tendência média anual e extremos sazonais. In: Atlas do Estado de São Paulo, IG-USP. 1976.

MONTEIRO, C. A. F. (Org.) Qualidade Ambiental na Bahia: Recôncavo e regiões limítrofes. Salvador: Secretaria de Planejamento, Ciência e Tecnologia - SEPLANTEC, 1987.

Geossistemas: a história de uma procura. São Paulo: Contexto, 2000.

MONTGOMERY, O. L. An investigation of the relationship between spectral reflectance and the chemical, physical and genetic characteristics of soils. 1976. 148f. Thesis (PhD in Soli Science) - Purdue University, West Lafayette, 1979.

MORAES, A. C. R. Geografia Pequena História Crítica. 2ª Edição. São Paulo: HUCITEC, 1983.

Meio Ambiente e Ciências Humanas. São Paulo: HUCITEC, 1994.

Geografia: pequena história crítica. 18ª . Edição. São Paulo: HUCITEC, 2002.

MORAES, M. E. B. Análise da legislação ambiental e das características físicas na ocupação urbana da estância de Campos do Jordão (SP). 148 f. 1999. Dissertação (Mestrado em Ciências da Engenharia Ambiental) - Escola de São Carlos/UNESP, São Carlos, 1999.

MORAES REGO, L. F. Notas sobre a geomorfologia de São Paulo e sua gênesis. Instituto Astronômico e Geographico de São Paulo, 28 p., 1932.

MOREIRA, M. A. Análise de Dados do Landsat/TM e do SPOT/XS através de índices de Vegetação - Fase II. São José dos Campos: INPE, 1992. 17 p. (INPE-5450-RPQ/663).

Déficit hídrico na cultura do trigo e o impacto na resposta espectral e em parâmetros agronômicos. 1997. 142 p. Tese (Doutorado) ESALQ/USP, Piracicaba, 1997.

Fundamentos do sensoriamento remoto e metodologias de aplicação. São José dos Campos: Editora Com Deus, 1르 ed., 2001. 250 p.

MOREIRA, M. A.; SOUZA, I. M. Análise de resultados de segmentação por crescimento de regiões em diferentes técnicas de processamento digital de dados do Landsat/TM para o mapeamento de áreas cafeeiras. In: SIMPÓSIO BRASILEIRO DE SENSORIAMENTO REMOTO, 10., 2001, Foz do Iguaçu. Anais... São Paulo: Imagem Multimídia. Seção de Comunicações Técnico-Científicas, 2001. p. 119-122. 1 CD-ROM.

MOREIRA, M. A.; AULICINO, L. C. M.; SHIMABUKURO, Y. E.; DUARTE, V.; RUDORFF, B. F. T.; RODRÍGUEZ YI, J. L.; SOUZA, I. M. Modelo de mistura espectral para identificar e mapear áreas de soja e milho em quatro municípios do Estado de Minas Gerais. In: SIMPÓSIO BRASILEIRO DE SENSORIAMENTO REMOTO, 9., 1998, Santos. Anais... São Paulo: Imagem Multimídia. Seção de Comunicações Técnico-Científicas, 1998. 1 CD-ROM. 
MORAN, M. S.; MAAS, S. J.; PINTER, P. J. Jr. Combining remote sensing and modeling for estimating surface evaporation and biomasa production. In: Remote Sensing Reviews, 12: 335-353, 1995.

MOURA, V. Imagens Multitemporais TM/Landsat 5 da Época de Pré-Plantio na Estimativa de Áreas destinadas a Culturas de Verão. 2000. 122 f. Dissertação (Mestrado em Sensoriamento Remoto) - Instituto Nacional de Pesquisas Espaciais, São José dos Campos. 2000. (INPE-7527-TDI/734).

MUEHRCKE, P. Map Use: reading, analysis and interpretation. Madison, Wisconsin: J P Publications, 1978.

NASA, 2008. MODIS-Web. Disponível em: <//modis.gsfc.nasa.gov/about/specifications.php >. Acesso em: 03 mar 2008. 09 set 2008.

Geocover/NASA Disponível em: <http://search.nasa.gov/geocover>. Acesso em: SRTM-Web. Disponível em: <http://www2.jpl.nasa.gov/srtm/>. Acesso em: 24 Out 2008.

MODIS-FTP Disponível em: <ttp://e4ftl01u.ecs.nasa.gov/MODIS Composites/> 2009. Acesso em: 24 nov 2009.

NEWELL, R. G. ; THERIAULT, D. G. Is GIS just a combination of CADD and DBMS? Mapping Awareness, v. 4, n.3, p. 42-45, 1990.

NOAL, R. E. A Cartografia Ambiental da Bacia da Lagoa Mirim (RS): uma reflexão metodológica acerca do emprego dos sistemas de informações geográficas. 2001. $178 \mathrm{f}$. Tese (Doutorado em Geografia Humana) - Faculdade de Filosofia, Letras e Ciências Humanas, Universidade de São Paulo, São Paulo, 2001.

NÓBREGA, R. A. DE A.; SANTOS, C. DOS; CINTRA, J. P. Comparação quantitativa e qualitativa entre o Modelo Digital gerado pelo SRTM e por aerofotogrametria. In: SIMPÓSIO BRASILEIRO DE SENSORIAMENTO REMOTO, 12., 2005 Goiânia. Anais... São Paulo: Imagem Multimídia. Seção de Comunicações Técnico-Científicas, 2005. p. 4437-4444. 1 CD-ROM.

NORGAARD, R. B. A base epistemológica da Agroecologia. In: ALTIERI, M. Agroecologia: as bases científicas da agricultura alternativa. Rio de Janeiro, Projeto Tecnologias Alternativas, 1989, p. 42-48.

NOVO, E. M. L. M. Sensoriamento remoto: princípios e aplicações. São Paulo: Edgard Blucher, 1989. 308 p.

ODUM, E. P. Ecologia. Rio de Janeiro: Editora Guanabara, 1988.

OLIVEIRA, L. Estudo Cognitivo do Mapa. São Paulo: IG/USP, 1978. (Série Teses e Monografias). 
OLIVEIRA, C. Dicionário Cartográfico. 4. ed. Rio de Janeiro: IBGE. 1993.

OLIVEIRA, J. B.; CAMARGO, M. N.; ROSSI, M.; CALDERANO FILHO, B. Mapa Pedológico do Estado de São Paulo. Instituto Agronômico de Campinas (IAC). 1999. Escala 1:500.000.

OTTERMAN, J. Reflection from soil with sparse vegetation. Advance Space Research, 1, p. 115-119, 1981.

Albedo of a forest modeled as a plane dense protusions. Journal of Climate Applied Meteorology, v. 23, n. 2, p. 297-307, 1984.

PALACIOS-ORUETA, A.; USTIN, S.L. Remote sensing of soil properties in the Santa Monica Mountains I. Spectral Analysis. Remote Sensing of Environment, New York, v.65, p. 170183, 1998.

PARANHOS, S. B. Cana-de-açúcar: cultivo e utilização. Campinas: Fundação Cargill,1987. V. $1,431 \mathrm{p}$.

PEREIRA, P. R. B. A cartografia ambiental para o município de São Sebastião-SP: análise e reflexão. 2000. 95 f. Dissertação (Mestrado em Geografia Humana) - Faculdade de Filosofia, Letras e Ciências Humanas, Universidade de São Paulo, São Paulo, 2000.

PEREIRA, N. R.; SCHUBACK, P. D' A.; JUNIOR, W. C. O uso de Técnicas de Geoprocessamento na detecção de áreas de Incompatibilidade de Uso, com base na Aptidão Agrícola das Terras e o Uso Atual - Estudo aplicado no Município Eng ${ }^{\circ}$ Paulo de Frontin - RJ. In: SIMPÓSIO BRASILEIRO DE SENSORIAMENTO REMOTO, 9., 1998, Santos. Anais... São Paulo: Imagem Multimídia. Seção de Comunicações TécnicoCientíficas, 1998. 1 CD-ROM.

PARENT, P. ; CHURCH, R. Evolution of Geographical Information Systems as decision making tools, Proceedings, GIS, 1987 p. 63-71, ASPRS/ACSM, Falls Church, VA.

PETRI, S.; FÚLFARO, V. J. Geologia do Brasil (Fanerozóico). São Paulo: EDUSP, 1983. $631 \mathrm{p}$.

PINTER, JR. P. J.; JACKSON, R. D.; EZRA, C. E.; GAUSMAN, H. W. Sun-angle and canopy - architecture effects on the spectral reflectance of six wheat cultivars. International Journal of Remote Sensing, London, v. 6, n. 12, p. $1813-1825,1985$.

PIZARRO, M.A. et al. Caracterização espectral de solos tropicais através de componentes principais e da correlação entre reflectância e análises químicas. In: SIMPÓSIO BRASILEIRO DE SENSORIAMENTO REMOTO, 10., Foz de Iguaçu, 2001. Anais ... São Paulo: [s.n], 2001. 1 CD-ROM.

PONÇANO, W. L. Mapa Geomorfológico do Estado de São Paulo. Instituto Tecnológico de São Paulo (IPT). 1981. São Paulo (SP): Escala 1:1000.000.

Projeto RADAMBRASIL. Levantamento de Recursos Naturais, 21-23. Instituto Brasileiro de Geografia e Estatística. Rio de Janeiro, 1981. 
RADIOAGENCIA NOTICIAS DO PLANALTO. Desastre na Educação. Por Hélio Schwartsman. Disponível em: <http://www.radioagencianp.com.br/>. Acesso em: 20 fev 2009.

RIBEIRO, F. L. Sistemas de Informações Geográficas aplicado ao mapeamento dos usos atual e adequado da terra do alto Rio Pardo - Botucatu, SP. 1998. $114 \mathrm{f}$. Dissertação (Mestrado em Agronomia) - Faculdade de Ciências Agronômicas da UNESP, $1998,114 \mathrm{f}$.

RICCOMINI, C. O Rift continental do Sudeste do Brasil. São Paulo, Instituto de Geociências - USP, Tese (Doutorado). São Paulo, 1991. 256 p.

RICHARDS, J. A. Remote sensing digital image analysis. New York, Springer - Verlag, 1993. 340p.

RIZZINI, C. T. Tratado de fitogeografia do Brasil: aspectos sociológicos e florísticos. v. 2. São Paulo: HUCITEC/EDUSP, 1979.

ROBINSON, A. H. Early thematic mapping in the history of cartography. Chicago. The Univeristy of Chicago Press, 1982.

RODRIGUEZ YI, J. L. Mapeamento e Monitoramento da Vegetação do Estado do Mato Grosso através de Imagens AVHRR-NOAA. 1998. 145 f. Dissertação (Mestrado em Sensoriamento Remoto - SR) - Instituto Nacional de Pesquisas Espaciais - INPE, São José dos Campos, 1998. (INPE-6816-TDI/638).

RODRIGUEZ, A. C. M. Mapeamento Multitemporal do Uso e Cobertura do Solo do Município de São Sebastião-SP, utilizando técnicas de Segmentação e Classificação de Imagens TM-Landsat e HRV-SPOT. São José dos Campos: INPE, 2000. 94 p. (INPE7510-PUD/39). Publicação Didática (Especialização em Sensoriamento Remoto).

RODRIGUEZ, A. C. M \& MOREIRA, J. C. Segmentação de imagens-fração derivadas do sensor TM e ETM+ para o mapeamento do uso e cobertura do solo do município de São Sebastião - SP. In: SIMPÓSIO BRASILEIRO DE SENSORIAMENTO REMOTO, 10, 2001, Foz do Iguaçu. Anais... São Paulo: Imagem Multimídia. Seção de Comunicações Técnicas Científicas, 2001, CD-ROM.

ROY, D. P.; BORAK, J. S.; DEVADIGA, S.; WOLFE, R. E.; ZHENG, M.; DESCLOITRES, J. The MODIS land product quality assessment approach. Remote Sensing of Environment. v. 83, n. 1-2, p. 62-76, Nov. 2002.

ROSS, J. L. S. (org) Geografia do Brasil. São Paulo: EDUSP, 1998.

Análise empírica de fragilidade dos ambientes naturais e antropizados. Revista de Departamento de Geografia. São Paulo: FFLCH/USP, n. 13, p. 77-106, 1994.

ROSS, J. L. S. e MOROZ, I. C. Mapa geomorfológico do estado de São Paulo. São Paulo: FFLCH/USP, IPT, FAPESP, 1997. 
ROUSE, J.W. et al. Monitoring vegetation systems in the great plains with ERTS. In: ERTS SYMPOSIUM, 3., 1973, Greenbelt. Anais ... Greenbelt: NASA, 1973, p. 309-317. (NASA SP-351).

RUDORFF, B. F. T.; BATISTA, G. T. Resposta espectral da cana-de-açúcar através dedados multitemporais do MSS do Landsat - 4. São José dos Campos. INPE, 1985. 12 p.(INPE - 3474-PRE/717).

RUDORFF, B. F. T.; BERKA, L. M. S.; MOREIRA, M. A.; DUARTE, V.; ROSA, V. G. C. Estimativa de Área Plantada com Cana-de-açúcar em Municípios do Estado de São Paulo por meio de imagens de satélites e técnicas de geoprocessamento: Ano safra 2004/2005. São José dos Campos: INPE, 2004 (INPE-11421-RPQ/762).

RUDORFF, B. F. T.;SHIMABUKURO, Y. E. ; CEBALLOS, J. C. O Sensor MODIS e suas aplicações Ambientais no Brasil. São José dos Campos: Parêntese, 2007. 425 p. ISBN 978-85-60507-00-9

RUDORFF, B. F. T.; SUGAWARA, L. M.; AGUIAR, D. A.; SILVA, W. F.; GOLTZ, E.; AULICINO, T. L. I. N.; CARVALHO, M. A.; ARENAS-TOLEDO, J. M.; BRANDÃO, D. Determinação da área cultivada com cana-de-açúcar na região centro-sul por meio de imagens de satélite de sensoriamento remoto - safras 2005/06 a 2008/09. São José dos Campos: INPE, 2009. 151 p. (INPE-15725-RPQ/822).

SALICHTCHEV, K. A. Algumas reflexões sobre o objeto e método da Cartografia depois da Sexta Conferência Cartográfica Internacional. Seleções de textos, n. 18, p. 17-24, 1988.

SANCHEZ. M. C. Conteúdo e eficácia da imagem gráfica. Boletim de Geografia Teor ética, v. 11, n. 21/22, p. 74-80, 1981.

SANT'ANNA NETO, J. L. As chuvas do Estado de São Paulo. São Paulo: FFLCH/USP, n., 1995

SANTOS, M. Por uma Geografia Nova. São Paulo: HUCITEC, 1978.

Espaço e Método. 4. ed. São Paulo: Nobel, 1985.

SANTOS, M.; SOUZA, M. A. A. ; SILVEIRA, M. L. Território: globalização e fragmentação. São Paulo: HUCITEC, 1996.

SANTOS, M. Metamorfoses do espaço habitado. São Paulo: HUCITEC, 1997.

SÃO PAULO (ESTADO). Comissão Geográfica e Geológica. Carte Générale de l'état de São Paulo avec indications sur l'agriculture, l'industrie et l'élévage. Escala 1:1.500.000. São Paulo, Uccle-Bruxelas, Patesson. 1920.

SÃO PAULO (ESTADO) Secretaria da Agricultura. Atlas do zoneamento agrícola do estado de São Paulo. Suplemento do vol. 2. Campinas, SA, 1977. 
SÃO PAULO (ESTADO) Secretaria do Meio Ambiente. Cerrado: Bases para conservação e uso sustentável das áreas do cerrado do Estado de São Paulo. São Paulo, SMA. 1995.

SÃO PAULO (ESTADO) Secretaria do Meio Ambiente. Atlas das Unidades de Conservação Ambiental do Estado de São Paulo. Parte I e II. São Paulo, Metalivros/SEMA. 1998.

SÃO PAULO (ESTADO). Secretaria do Meio Ambiente. Documento Ambiental: Série Projetos de Preservação da Mata Atlântica - Plano de Manejo das Unidades de Conservação (UC’s), Estação Ecológica do Bananal. São Paulo, 1998.

SÃO PAULO. Portal do Governo. Conheça São Paulo. Uma potência chamada São Paulo. Disponível em : < http://www.saopaulo.sp.gov.br/saopaulo/ >. Acesso em: 10 abr 2010

SCHAEFER, F. Excepcionalísimo en Geografía. Barcelona: Ediciones de La Universidad de Barcelona, 1980.

SCHOLTEN, H. J. ; STILLWELL, J. C. H. Geographic Information Systems for urban and regional planning. Dordrech: Klumer Academic Publishers, 1990. 261 p.

SCHOWENGERDT, R. A. Remote Sensig, Models and Metrhods for Image Processing. San Diego: Academic Press, 1997. 522 p.

SETZER, J. Atlas Climático e Ecológico do Estado de São Paulo. São Paulo, CIBPU. 1966.

SHIMABUKURO, Y. E.; SMITH, J. A. Imagens sombra para áreas reflorestadas de Eucalyptus e Pinus obtidas de medidas multiespectrais do Landsat. In: SIMPÓSIO BRASILEIRO DE SENSORIAMENTO REMOTO, 3., 1988, Natal - RN. Anais... São José dos Campos: INPE, 1988. v. 3, p.572-577.

SHIMABUKURO, Y. E.; MELLO, E. M. K.; MOREIRA, J. C.; DUARTE, V. Segmentação e classificação da imagem sombra do modelo de mistura para mapear desflorestamento na Amazônia. São José dos Campos: INPE, 1997. 16 p.

SHIMABUKURO, Y. E.; DUARTE, V. ; SANTOS, J. R.; MELLO, E. M. K.; MOREIRA, J. C. Levantamento de áreas desflorestadas na Amazônia através de processamento digital de imagens orbitais. Revista Floresta e Ambiente, v. 6, n. 1, p. 38-44, jan./dez., 1999.

SHORT, N.M. Tutorial Vegetation Applications - Agriculture, Forestry and Ecology. RST, section 3. Washington, DC. Em: <//rst.gsfc.nasa .gov/Sect3/Sect3 1.html> Acesso: 10 Fev. 2008.

SKOLONSKI, H. H. (Coord.) Manual técnico de uso da terra. Rio de Janeiro: IBGE, 1999. 59 p. (Série Manuais Técnicos em Geociências, 7).

SLATER, P. N. Optics and optical System. Massachusetts: Addison-Wesley, 1980. 575 p. 
SILVA, L. R. A Natureza Contraditória do Espaço Geográfico. 2 ed. São Paulo: Contexto, 2001.

SILVA, A. DE B. Sistemas de Informações Geo-referenciadas: conceitos e fundamentos. Campinas, SP: Editora da Unicamp, 1999, 236 p.

SILVA, C. P. Ensaio de uma Síntese da Evolução da Geografia. São Paulo: IBGE. 1943. 135 p. (Boletim n.3; Diretório Regional de Geografia, n.3)

SILVA, V. G. da Legislação Ambiental Comentada. $2^{\mathrm{a}}$ edição. Belo Horizonte: Fórum, 2004. 592 p.

SIMIELLI, M. E. R. O mapa como meio de comunicação: implicações no ensino da geografia do $1^{\circ}$. grau. 1986. 205f. Tese (Dourotrado em geografia) - Faculdade de Filosofia, Letras e Ciências Humanas, Universidade de São Paulo, 1986.

SIMONETT, D. S. The Development and Principles of Remote Sensing. In: Manual of Remote Sensing. Falls Church, VA: American Society of Photogrammetry, 1983. p. 1-34.

SOARES, P. C.; LANDIM, P. M. B.; FÚlFARO, V. J.; SOBREIRO NETO, A. F. Ensaio de caracterização estratigráfica do Creatáceo no Estado de São Paulo: Grupo Bauru. Revista Brasileira de Geociências, São Paulo, v.10, n.3, p.177-185, 1980.

SOS Mata Atlântica. Disponível em: <http://www.sosmatatlantica.org.br> Acesso: 10 set 2003.

SOTCHAVA, V. B. O estudo dos Geossistemas. Métodos em Questão, São Paulo, v. 6, 1976, p.1-52.

SOUZA FILHO, C. R. O Relevo das Américas como nunca antes visto. InfoGEO, Ano 5, v. 30, p. 54-58, Maio de 2004.

SOUZA, S. T. Algumas reflexões sobre o espaço geográfico e produção do espaço no capitalismo. In: ENCONTRO DE GEÓGRAFOS DA AMÉRICA LATINA, 10., São Paulo, 2005, Anais... São Paulo: Imagem Multimídia. Seção de Comunicações Técnico-Científicas, 2005.

STEFFEN, C. A.; GAMA, F. F.; NOVO, E. M. L. M. Teste operacional de aquisição de dados aerotransportados - SADA, o experimento de Barra Bonita. São José dos Campos: INPE, 1992 (INPE-5451-NCT/305).

STRAHLER, A.; MUCHONEY, D.; BORAK, J.; FRIEDL, M.; GOPAL, S.; LAMBIN, E.; MOODY, A. MODIS land cover and land-cover change products algorithm theoretical basis document (ATBD). Version 5.0 Center for Remote Sensing, Department of Geography, Boston: University, May, 1999, 72 p.

STRAHLER, A.; TOWNSHEND, J. R. G.; MUCHONEY, D.; BORAK, J.; FRIEDL, M.; GOPAL, S.; HYMAN, A.; MOODY, A.; LAMBIN, E. MODIS land cover product algorithm theoretical basis document (ATBD). Version 4.1 Washington: NASA, 1996, $102 \mathrm{p}$. EOSMTPE, Documentation. 
STONER, E.R.; BAUMGARDNER, M.F. Characteristic variations in reflectance of surface soils. Soil Science Society American Journal, Madison, v.45, p. 1161-1165, 1981.

TAYLOR, D. R. F. Uma base conceitual para a Cartografia: novas direções para a era da informação. Seleção de textos. Laboratório de Ensino e Material Didático, 1994. Caderno de Textos - Série Palestras. São Paulo: LEMADI- Depto. Geografia-FFLCH-USP, Ano I, no 1, pp.11-19, ago. 1992

The Concepto f Cybercartographi. In: M. Peterson (Editor), Maps and the Internet. Elsevier, Cambridge, 2003.

TELLES, J.;SAMII, M. V.;DOLL, C. E. Overview of TDRSS. Advances in Space Research, v. 16, p.1267-1276, 1995.

TERRA BRASILIS, 2008. Atlas Miller, cerca de 1519. (Mapas de Santos). Disponível em: < http://www.novomilenio.inf.br/ > Acesso em: 08 Set 2010.

THEATRUM ORBIS TERRARUM or Theatrum Orbis Terrarum refers to an Atlas by Dutch Cartographers Abraham Ortelius (1527 - 1598) which was later updated by the Blaeu family. 1570. Disponível em: < http://commons.wikimedia.org/wiki/> Acesso: 15 Set 2010.

TOMLINSON, R. F. The Canada geographic information systems. In: FORESMAN, T. W. The History Information Systems. New Jersey: Prentice Hall, 1998, p. 21-32.

TOWNSHEND, J. R. G.; JUSTICE, C. O. Selecting the spatial resolution of satellite sensors required for global monitoring of land transformations. International Journal of Remote Sensing, v. 9, n. 2, p.187-236, Feb. 1988.

TRICART, J. Ecodinâmica. Rio de Janeiro: IBGE, 1977.

TRIVIÑOS, A. N. S. Introdução à pesquisa em ciências sociais: a pesquisa qualitativa em educação. São Paulo: Atlas, 1987.

TROPPMAIR, H. A cobertura vegetal primitiva do Estado de São Paulo. Biogeografia v. 1, p. 1-10, 1969.

H. Ecossistemas e Geossistemas do Estado de São Paulo. Boletim de Geografia Teorética, v. 13, n. 25, p. 27-36, 1983.

TUCKER, C. J. Red and photographic infrared linear combination for monitoring vegetation. Remote Sensing of Environment, v. 8, n. 2, p. 127-150. 1979.

TUFTE, E. R. The visual display of quantitative information. 15 ed. Connecticut: Graphic Press, 1997, p. 24

UNIÃO DA AGROINDÚSTRIA CANAVIEIRA DE SÃO PAULO (UNICA). Estatísticas agrícolas. São Paulo, 2005. Disponível em: < http://www.portalunica.com.br >. Acesso em: 10 mar 2009. 
UNITED STATES GEOLOGICAL SURVEY (USGS), 2008. Mosaic of World (GEOCOVERLandsat). Disponível em: <http://landsat.usgs.gov/gallery view.php >. Acesso em: 09 set 2008

SRTM - Mission Summary. Disponível em: <http://srtm.usgs.gov/Mission/>. Acesso em: Maio de 2008.

VALENTE, A. L. S. Uma metodologia para determinação de áreas de risco através de geoprocessamento e sensoriamento remoto. In: SIMPÓSIO BRASILEIRO DE SENSORIAMENTO REMOTO, 9., 1998, Santos. Anais...São Paulo: Imagem Multimídia. Secção de Comunicações Técnico-Científicas, 1998. 1 CD-ROM.

VALERIANO, M. M. Modelo Digital de Elevação com Dados SRTM disponíveis para a América do Sul. São José dos Campos: INPE, 2004. 72 p.

VENEZIANE, P.; ANJOS, C. E. Metodologia de Interpretação de Dados de Sensoriamento Remoto e Aplicações em Geologia. São José dos Campos, INPE, 1982. 61 p. (INPE - 2227-MD/041).

VERHOEF, W.; BUNNIK, N. J. J. Influence of crop geometry on multispectral reflectance determined by the use of canopy reflectance models. In : INTERNATIONAL COLLOQUIUM ON SIGNATURES OF REMOTELY SENSED OBJECTS, 1981, Avignon, France.

Proceedings... p. $273-290$

VERONA, J. D. Classificação e monitoramento fenológico foliar da cobertura vegetal na região da floresta Nacional do Tapajós - Pará, utilizando dados multitemporais do sensor " Thematic Mapper" (TM) do Landsat. 2002. 159 f. Dissertação (Mestrado em Sensoriamento Remoto) - Instituto Nacional de Pesquisas Espaciais, São José dos Campos, 2002.

VICTOR, M. A. M. et al. A devastação florestal. São Paulo: Sociedade Brasileira de Silvicultura, 1979. $48 \mathrm{p}$.

VISCARRA-ROSSEL, R.A.; MC BRATNEY, A.B. Laboratory evaluation of a proximal sensing technique for simultaneous measurement of soil clay and water content. Geoderma, Amsterdam, v. 85, p. 19-39, 1998.

YI, J. L. R. Dados do sistema sensor MODIS-TERRA para avaliação e monitoramento de áreas agrícolas na Região Sul do Brasil. 2005. 181f. Tese (Doutorado em Engenharia). Escola Politécnica da Universidade de São Paulo. Departamento de Engenharia de Transportes. São Paulo, 2005.

WATRIN, O. S.; VENTURIERI, A.; SAMPAIO, S. M. N. Análise multitemporal do uso da terra e suas inter-relações com a cobertura vegetal em comunidades rurais do nordeste paraense. In: SIMPOSIO BRASILEIRO DE SENSORIAMENTO REMOTO, 9., 1998, Santos. Anais... São Paulo: Imagem Multimídia. Seção de Comunicações Técnico-Científicas, 1998. 1 CD-ROM.

WATRIN, O. S., SHIMABUKURO, Y. E.; CRUZ, C. B. M., SOUZA, I. M. Bandas sintéticas derivadas de modelo de mistura espectral na avaliação da dinâmica da paisagem em assentamento rural na fronteira agrícola Amazônica. In: SIMPÓSIO BRASILEIRO DE 
SENSORIAMENTO REMOTO, 11., 2003, Belo Horizonte. Anais... São Paulo: Imagem Multimídia. Seção de Comunicações Técnico-Científicas, 2003. p. 729-736. 1 CD-ROM.

WIKIPEDIA. Sistema de Cores de Munsell. Disponível em: <http://pt.wikipedia.org/wiki/> Acesso em: 10 Fev 2009.

WOLFE, R. E.; NISHIHAMA, M. FLEIG, A. J.;KUYPER, J. A.;ROY, D. P.;STOREY, J. C.;PATT, F. S. Achieving Sub-Pixel Geolocation Accuracy in Support of Modis Land Sciense. Remote Sensing of Environment, v. 83, n. 1-2, p. 31-49, Nov. 2002. 


\section{VIII - APÊNDICE}

Neste item apresentamos os programas utilizados na Linguagem Espacial para Geoprocessamento Algébrico (LEGAL). Os mesmos foram aplicados pelo software SPRING e ajudaram no desenvolvimento desta pesquisa para a elaboração do Mapa de uso e cobertura da terra do estado de São Paulo.

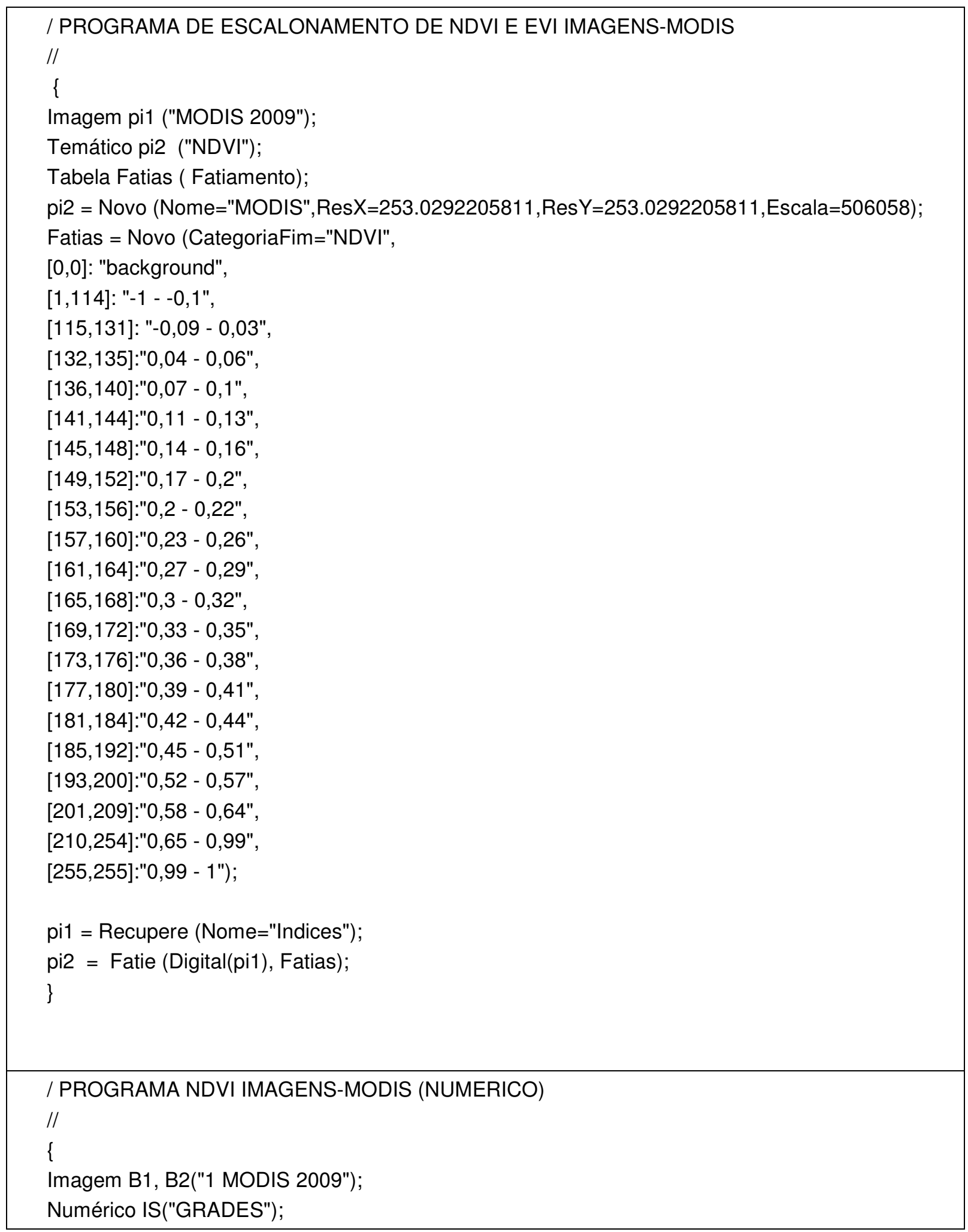


//calculo do NDVI

//

B1=Recupere(Nome="2 MosB2_Red");

B2=Recupere(Nome="3 MosB3_NIR");

IS $=\quad$ Novo(Nome="NDVI_Numérico", $\quad$ ResX=253.0292205811, ResY=253.0292205811, Escala $=506058$, Min=-1, Max=1);

IS=(Numérico(B2) - Numérico(B1))/(Numérico(B2) + Numérico(B1));

\}

/ PROGRAMA COPIAR CLASSES TEMÁTICAS

//

\{

Temático entrada ("5 Rede HIDROGRÁFICA"), saída ("UsoTERRA_Tudo");

entrada = Recupere(Nome="Drenagem");

saída = Novo(Nome="Corpos d'água", ResX=253.0292205811, ResY=253.0292205811, Escala $=506058$;

saída = entrada.Classe == "Corpos d'água"? entrada : saída;

\} 